\title{
ANCIENT WORLDS
} IN FILM AND

\section{TELEVISION}

Gender and Politics

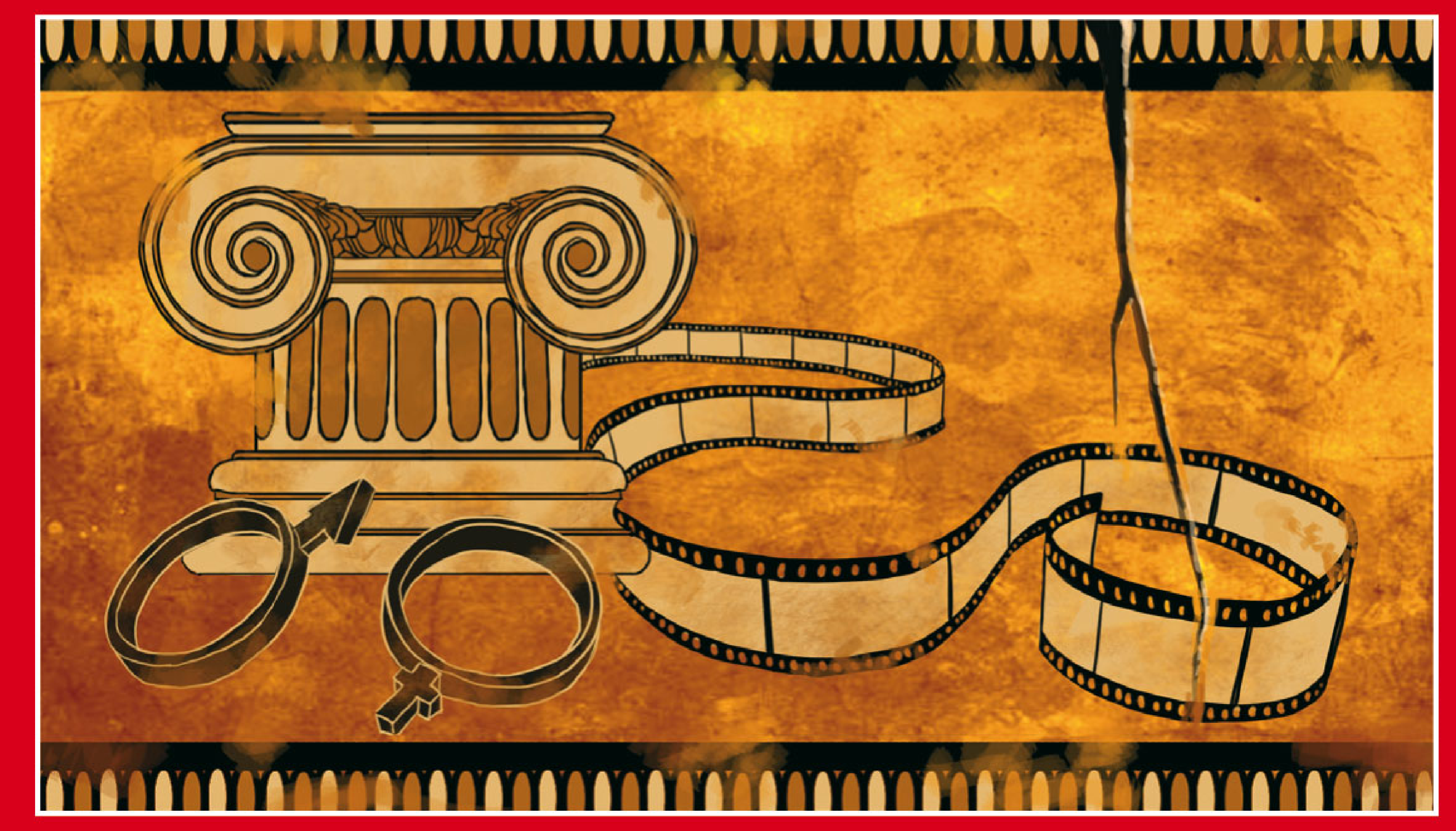

Edited by

Almut-Barbara Renger

and Jon Solomon

B R I L L 
Ancient Worlds in Film and Television 


\title{
Metaforms
}

Studies in the Reception of

Classical Antiquity

\author{
Editors-in-Chief \\ Almut-Barbara Renger, Freie Universität Berlin \\ Jon Solomon, University of Illinois at Urbana-Champaign \\ John T. Hamilton, Harvard University

\section{Editorial Board} \\ Kyriakos Demetriou, University of Cyprus \\ Constanze Güthenke, Princeton University \\ Miriam Leonard, University College London \\ Mira Seo, University of Michigan
}




\title{
Ancient Worlds in \\ Film and Television
}

\author{
Gender and Politics
}

\author{
Edited by
}

Almut-Barbara Renger and Jon Solomon

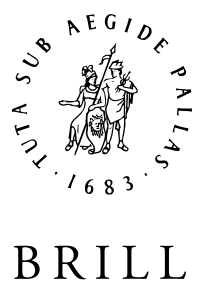


This is an open access title distributed under the terms of the CC BY-NC 4.0 license, which permits any non-commercial use, distribution, and reproduction in any medium, provided the original author(s) and source are credited. Further information and the complete license text can be found at https://creativecommons.org/licenses/ by-nc/4.0/

The terms of the Cc license apply only to the original material. The use of material from other sources (indicated by a reference) such as diagrams, illustrations, photos and text samples may require further permission from the respective copyright holder. with Knowledge Unlatched. More information about the initiative can be found at www .knowledgeunlatched.org.

\section{Cover illustration by Floor Steinz.}

\section{Library of Congress Cataloging-in-Publication Data}

Ancient worlds in film and television : gender and politics / edited by Almut-Barbara Renger and Jon Solomon.

p. cm. - (Studies in the reception of classical antiquity)

Includes bibliographical references and index.

ISBN 978-90-04-18320-9 (hardback : alk. paper) — ISBN 978-90-04-24192-3 (e-book : alk. paper) 1. Historical films-History and criticism. 2. Civilization, Ancient, in motion pictures. 3. Civilization, Ancient, on television. 4. Sex role in motion pictures. 5. Politics in motion pictures. 6. Motion pictures and history. 7. Television and history. I. Renger, Almut-Barbara. II. Solomon, Jon, 1950-

$$
\begin{aligned}
& \text { PN1995.9.H5A55 } 2012 \\
& 791.43^{\prime} 658-\mathrm{dc} 23
\end{aligned}
$$

This publication has been typeset in the multilingual "Brill" typeface. With over 5,100 characters covering Latin, IPA, Greek, and Cyrillic, this typeface is especially suitable for use in the humanities. For more information, please see www.brill.com/brill-typeface.

ISSN 2212-9405

ISBN 978-90-04-18320-9 (hardback)

ISBN 978-90-04-24192-3 (e-book)

Copyright 2013 by the Authors. Published by Koninklijke Brill NV, Leiden, The Netherlands. Koninklijke Brill NV incorporates the imprints Brill, Global Oriental, Hotei Publishing, IDC Publishers and Martinus Nijhoff Publishers.

Brill has made all reasonable efforts to trace all rights holders to any copyrighted material used in this work. In cases where these efforts have not been successful the publisher welcomes communications from copyright holders, so that the appropriate acknowledgements can be made in future editions, and to settle other permission matters.

All rights reserved. No part of this publication may be reproduced, translated, stored in a retrieval system, or transmitted in any form or by any means, electronic, mechanical, photocopying, recording or otherwise, without prior written permission from the publisher. Authorization to photocopy items for internal or personal use is granted by Koninklijke Brill NV provided that the ap.propriate fees are paid directly to The Copyright Clearance Center, 222 Rosewood Drive, Suite 910, Danvers, MA 01923, USA.

Fees are subject to change.

This book is printed on acid-free paper. 


\section{CONTENTS}

Introduction

Almut-Barbara Renger and Jon Solomon

\section{HistoricAl ANCIENTS}

Ben-Hur and Gladiator: Manifest Destiny and the Contradictions of American Empire

Jon Solomon

Muscles and Morals: Spartacus, Ancient Hero of Modern Times

Thomas Späth and Margrit Tröhler

With Your Shield or On It: The Gender of Heroism in Zack

Snyder's 300 and Rudoph Maté's The zoo Spartans

Thorsten Beigel

“This is Sparta!": Discourse, Gender, and the Orient in Zack

Snyder's 300

Jeroen Lauwers, Marieke Dhont and Xanne Huybrecht

"Everybody Loves a Muscle Boi": Homos, Heroes, and Foes in

Post-9/11 Spoofs of the 300 Spartans

Ralph J. Poole

The Womanizing of Mark Antony: Virile Ruthlessness and

Redemptive Cross-Dressing in Rome, Season Two

Margaret M. Toscano

Cleopatra's Venus 


\section{Mythological AnCIEnts}

Over His Dead Body: Male Friendship in Homer's Iliad and Wolfgang Petersen's Troy (2004) Andreas Krass

Models of Masculinities in Troy: Achilles, Hector and Their Female Partners

"Include me out" - Odysseus on the Margins of European Genre Cinema: Le Mépris, Ulisse, L'Odissea

Christian Pischel

Between Mythical and Rational Worlds: Medea by Pier Paolo Pasolini

"Universal's Religious Bigotry Against Hinduism": Gender Norms and Hindu Authority in the Global Media Debate on Representing the Hindu God Krishna in Xena: Warrior Princess Xenia Zeiler

Mythological AND Historical Thematics

Ancient Women's Cults and Rituals in Grand Narratives on Screen: From Walt Disney's Snow White to Olga Malea's Doughnuts with Honey Svetlana Slapšak

Pandora-Eve-Ava: Albert Lewin's Making of a "Secret Goddess" ..... 271 Almut-Barbara Renger

Phryne Paves the Way for the Wirtschaftswunder: Visions of Guilt and "Purity" Fed by Ancient Greece, Christian Narrative, and Contemporary History 
The New Israeli Film Beruriah: Between Rashi and Talmud, between Antiquity and Modernity, between Feminism and Religion 



\section{INTRODUCTION}

\section{Almut-Barbara Renger and Jon Solomon}

The anthology you hold in your hands is the first volume of Metaforms: Studies in the Reception of Classical Antiquity. The series aims to publish monographs and collected volumes devoted to the critical investigation of a broad and diverse field: the reception of Greco-Roman antiquity. It is particularly committed to research that considers the practices, premises, and constituting effects of creative work that deals directly with past traditions in a variety of media and discourses including, but not limited to, literature, film, and the visual arts.

We decided to launch the series with a collection of papers on film. Cinema, television, and video have taken a central place in our daily lives and influence us as individuals and in our social relationships. There are multiple operatives that determine these processes. One is that the camera's viewpoint creates and determines our field of vision, suggesting a uniquely configured but vividly memorable impression of reality. With a new method of seeing, viewing the mechanically or electronically rendered representation of a physically rendered experience, viewers can identify their own perception as if they themselves had been present at given circumstance. As a result, the camera's viewpoint shapes and constructs our body and gender relationships. We "see" as if innate and natural a visual recollection of masculine and female bodies - a combination of powerful muscles and soft skin, lavish costumes, hairdos, make-up and settings, as well as the pathos laden music and a certain kind of language aesthetic, satisfying both hetero- and homosexual tastes. It is our challenge in the study of image making and reception in the twenty-first century to comprehend how all this is happening and how the film industry is changing our understanding of ourselves, our culture and society, and how cultural and social knowledge and experience are conveyed through film and moving images.

More than a hundred years ago, filmmakers made their primary focus innovative and widely promulgated visions of antiquity, creating a profound effect on the critical, popular, and scholarly reception of antiquity. In this volume, scholars from a variety of countries and varying academic disciplines have addressed film's way of using the field of Classical 
Reception to investigate, contemplate, and develop hypotheses about present-day culture and societies with a particular emphasis on gender and gender roles, and their relationship to one another. Looking back through a century of film history, this collection examines how the portrayal of figures, myths, and events of antiquity influence and affect our relationship to gender and our body. To this end, the papers here anthologized consider moments of ancient history as well as the technical innovations and stylistic advances of film history from its beginnings until today. With the change of film contexts, social structures and the presentation of gender and gender roles have changed over the years. The present volume asks why and to what extent these constructions, destructions, and reconstructions happened by taking into consideration production conditions, international sales strategies as well as aspects of Hollywood's so-called production code, the film studios' codex for self-censorship that they initiated in response to pressure from social and religious interest groups.

These questions are closely interwoven with explanations and illustrations of motivic and structural forms of reception as well as gender issues both in modern films and ancient settings and cultures. Particular consideration is given to the meeting, or clash, of different concepts and ideas of gender, and expectations about the characteristics, aptitudes, and likely behaviors of femininity and masculinity. The concepts and ideas at stake include not only representations of the feminine, the masculine, and homosexuality or homoeroticism, but also the reproduction of imperial power and power structures, the exploitation of the human - both male and female - body, and issues of the Other. Comparisons reveal, for instance, that woman-bodies, such as the paradigmatic Pandora figure of Greek mythology, whose making the mighty Olympian Zeus entrusted to the divine blacksmith Hephaestus, both in ancient cultural activity and modern artistic production - here film - have been and are frequently constructed by a male artist to serve as a projection screen for male anxieties about women and to win the creator power and/or success in the field in which he is competing.

The volume is the result of "Antiquity in Film - Gender on Screen," an international conference organized by Almut-Barbara Renger and held in December 2009 at the Freie Universität Berlin. Like this publication, the event was sponsored by the university's funding allocation for gender equality promotion and the Center for International Cooperation, the latter being responsible for strengthening and expanding the international research and academic network of Freie Universität. The conference, attended by over thirty scholars, each presenting a paper in either 
English or German, was dedicated entirely to studying gender and politics in representations of antiquity in film. The event spanned three days and was formatted in seven (at times parallel) panels, with an emphasis of analyses on how filmic constructions of masculinity and femininity shape and are shaped by interacting economic, political, and ideological practices. Together with issues germane to gender and media theory, the panels addressed particular aspects of production and sale, the effects of the Cold War and its end, and residual effects of colonialism such as unequal power-relations privileging some and marginalizing others.

A keynote by Jon Solomon opened the conference with an historical overview of the relationship between reception of antiquity, film, and existing power structures, especially in the United States, providing an opportune springboard for other presentations that were to look at specific films and their portrayal of antiquity and gender in finer detail. Films under consideration ranged from Hollywood and international blockbusters like Troy to vintage studio productions like Snow White and the Seven Dwarfs to uniquely conceived auteur films like Pasolini's Medea and Godard's Le mépris, to TV series such as ROME; Xena, Warrior Princess; and Hercules: The Legendary Journeys. Although focusing on mostly Greco-Roman antiquity, topics from ancient Judaism and Christianity were also represented, thereby giving the term "antiquity" a wider scope than ancient Greece and Rome. By bringing together scholars from many different countries and fields, the conference amply represented the variety and flexibility of contemporary film studies' interdisciplinary approaches. The goal was to channel collective scholarly expertise in classical literature, women studies, gender studies, film studies, and a variety of other disciplines alongside life experiences to produce papers employing innovative approaches and methodologies to this sizeable corpus of films. After more than thirty years since the establishment of the sub-discipline in classical studies focusing on representations of the ancient world in film and television, the conference was one of the first and certainly the most comprehensive and most broadly represented to reexamine specifically filmed representations of heroic paragons of masculinity, women as queens, wives, slaves, and sacrificial victims, and ancient social and political relationships both within the bedroom and in large political constructs.

Just as gender studies is in itself an area that incorporates methods and approaches from a great many disciplines, the discussion at the conference was very wide ranging. It included sociological approaches of the 1950s, Jacques Lacan's psychoanalytical theories, and the work of Judith Butler, who has contributed to the fields of feminism, queer theory, 
political philosophy, and recent theory in queer fiction, which is further implemented by Scott Bravmann, who explores the complexity of lesbian and gay engagement with history by considering how historical discourses animate the present. Our discussions incorporated some of the latest debates within gender studies, entailing postcolonial theories as well as oriental- and racist-critique, among them Gayatri Spivak's Can the Subaltern Speak? (1988) and The Postcolonial Critic (1990). Approaches in recent film and gender theory have examined the performance and negotiation not only of gender, but also of cultural background and national as well as ethnical identities, using concepts such as "bricolage" to bring various facets of contemporary film into sharper focus. The body's boundaries and the transgression of these boundaries, e.g., in scenes of excessive violence, have become dominant motifs. In the last few years, the literature of antiquity has been adapted to film and turned into blockbuster Hollywood films, yet its relationship to these motifs has rarely been discussed. It is therefore all the more important to examine the significance of these films and their socio-political function and thereby to develop interpretations that reach beyond what has been accepted for the past several years as analytical common sense.

For this reason, the conference aimed both to examine which position of power and difference is negotiated beyond a specific representation of gender, and to explore how contemporary and political agendas possibly motivate (post-)colonial power relations, cultural superiority, gender codifications, and the representation of state sovereignty. In our discussions of these connections and dynamics, the use of ancient figures and motifs as well as their strategies of legitimizing specific forms of representation were put to critical analysis. So, for example, by looking at the Greek and Roman representation of the Persian ethos and other Eastern characters and antagonists, the discussion focused on the image of the Orient - an image formed through the Western eye, especially by Hollywood films, as the American film 300 clearly demonstrates. With a worldwide box-office gross of over \$445 million dollars in 2007, 300 ranks among the most commercially successful films of all time. This made as an important point of departure Edward Said's thesis that the Western image of the Orient was consciously developed and propagated to acquire and preserve colonial power.

Although the ancient world has provided significant and repeated inspiration to filmmakers for more than a century, the conference focused for the most part on more recent films, particularly those that have been produced in the past seventeen years in the wake of the worldwide success 
of the syndicated television series Hercules: The Legendary Journeys in the mid-199os. Seven of the sixteen papers in this volume offer studies of the most successful high-profile films of this period, which provide both Hollywood stereotypes and startling innovations. Gladiator (2000), Troy (2004), and 300 (2006) each had worldwide receipts of over $\$ 450$ million and rank among the top 100 box-office successes of all time. Seven papers examine such popular or critically acclaimed made-for-television series as Xena: Warrior Princess (1996-2001), Franco Rossi's L'Odissea (1968), and the HBO/BBC Rome (2005-2007), or lesser known European works, e.g., Loukoumades me meli (2005) and Beruriah (2007), or the parodies of 300 - Meet the Spartans (2007) and United 300 (2007). Six of the papers delve into the great flourishing of Biblical and Greco-Roman films produced between 1945 and 1970, including Caesar and Cleopatra (1945), Ulysses (1954), Ben-Hur (1959), Spartacus (1960), The zoo Spartans (1962), Cleopatra (1963), and Medea (1969). And a number of papers explore older films which were not set in antiquity but treat ancient subjects or themes, including such older films as Snow White and the Seven Dwarfs (1937), Pandora and the Flying Dutchman (1951), The Sinner (Die Sünderin [1951]), and a recent Israeli production, Beruriah (2009).

This volume follows an organizational integrity based on a working typology divided between Ancients and Thematics. "Ancients," like "Westerns," are set, but not produced, in the historical or legendary past and are appropriately divided into historical and mythological rubrics. Thematics are usually set in the modern world. Drawing from ancient themes or making specific allusions to the Greco-Roman world by nature, they feature neither traditional historicity or mythopoesis and therefore contain different characters and expectations that yield a variety of distinct analytical approaches. A great many of the modern myths these films transfer and produce by drawing on ancient material are characteristically signs in the Barthesian sense of culturally constructed collective fictions or cliches, with their roots in language, but to which something has been added.

Historical Ancients: By design this volume has relegated technical discussions of historical authenticity and narrative sources to such highly recommended compilations as Martin Winkler's anthologies on Gladiator, Troy, Spartacus, and The Fall of the Roman Empire. Instead, we work under the assumption that the artists and producers created a commercially or artistically valid product, so our studies can all focus instead on issues of gender and politics. The seven contributions here investigate action/ adventure films recreating both Greek and Roman historical figures and events. 
"Ben-Hur and Gladiator: Manifest Destiny and the Contradictions of American Empire" by Jon Solomon is a paper on representation of antiquity in Hollywood cinema as codifications for power structures. His essay points out that the spectacular success of both films reflects a schizophrenic paradox deeply embedded within the American psyche - the simultaneous assumptions that the United States should be isolated from the world and that American exceptionalism warrants neutralizing the inevitable antithesis between freedom and empire by calling occupation and domination peace and beneficence. The two films contain multiple narrative parallels. Both tell the story of a prominent subject of the Roman Empire who falls victim to personal betrayal and politically motivated Roman villainy, loses his nuclear family, is extra-judicially imprisoned or enslaved, kills the Roman villain during a public entertainment in a spectacular venue. Most important is that the ultimate result of his triumph is that he helps to revolutionize the entire Roman Empire, in the establishment and triumph of Christianity and representative democratic government, respectively. The nineteenth-century concept of manifest destiny, long an embattled concept, resurfaces as the cinema audience intuitively senses that this is the triumph of good over evil, the same Manichean duality that can blind an American or Americanized audience to the idea that their empire is the modern equivalent of the Roman Empire - the villainous enterprise in both films.

Thomas Späth and Margrit Tröhler in "Muscles and Morals: Spartacus, Ancient Hero of Modern Times" delineate muscular heroes by discussing a whole series of Spartacus films from 1913 to 2010. The paper shows how popular culture uses and transforms "the myth of antiquity" just as ancient cultures employed their myths as references with which stories for the present were shaped. The first page of their paper defines their approach through Jean-Louis Comolli's metaphor of "the body too much" to distinguish historical personages from their physical embodiment on screen. In the best known filmic representations of Spartacus from the 1913 Italian Spartaco to the Stanley Kubrick Spartacus and the more recent television versions, the moving image renders Spartacus as a spectacular body. In developing Comolli's construct, Späth and Tröhler show how twentiethcentury popular culture socially constructs the body of the ancient hero as an exemplar of masculinity and how male bodies are thereby commodified as - often exotic-oriental - objects of desire whose unfettered physicality and performance confers upon the artificiality of film a physical authenticity. 
Thorsten Beigel's "With Your Shield or On it: The Gender of Heroism in Zack Snyder's 300 and Rudolph Maté's The 3 oo Spartans" offers a reverse reading of the gender content of 300 . The popular perspective derives from a masculine visual feast underscored by muscular men with welldefined abs. Beigel focuses on the interplay between the popular construction of male heroism in the film and the pervasive influence of its female gender stereotypes. Unlike Frank Miller's original graphic novel, the opening sequences of Snyder's film establish Leonidas as an affectionate father and husband, and not only does his wife Gorgo participate in the audience with the Persian envoys, she is the one who suffers insults and gives approval for Leonidas to execute them. Similarly, the later episodes in which Gorgo has a sexual encounter with the treacherous Theron, addresses the council, and then stabs him to death (also not found in the graphic novel) provide stark contrasts with the earlier familial sequences. Beigel demonstrates that Gorgo offers a pragmatic figure of identification for the female demographic while also permitting the implementation of an additional sub-plot that helps to distinguish the hero Leonidas from his political adversaries. Gorgo's character serves to underline the depiction of Leonidas as the brave, masculine ideal as opposed to those of the villain Theron and the sexually ambiguous Persian King Xerxes. Ultimately, Gorgo completes the construction of the Spartan myth, which Miller exclusively defines in terms of male bravery but to which Snyder assigns a female "co-hero." Beigel also supports his reading by recounting our ancient sources (Plutarch, Herodotus) on Spartan women and 30o's cinematic source, Maté's The zoo Spartans.

In “'This is Sparta!': Gender and the Orient in Zack Snyder's 3oo," Jeroen Lauwers considers the representation of gender and gender relations, and how film functions to reinforce existing constructs. The paper describes how the Miller/Snyder form of innovative historical discourse ventured into the middle ground between the Greek historiographical tradition and modern fiction, which makes viewers conscious and often critical of the film's contemporary political and historical perspectives of the Middle East. In his narratological analysis, Lauwers points out that Snyder's Greeks - Spartans for once, not Athenians - are not necessarily forbearers of Western civilization but historical people with their own assumptions, stereotypes, and values, which they characteristically defined in opposition to the barbaric Other. In contrast to the impression generated by many other Hollywood blockbusters set in the ancient world, the worldview in the film is not immediately transmittable from the Spartans to 
ourselves. Lauwers concludes that a genuine dialogue between Greek and modern culture can only begin with the acknowledgment of Otherness.

Ralph Poole's “'Everybody Loves a Muscle Boi': Homos, Heroes, and Foes in Post-9/11 Spoofs of the 300 Spartans" explores the popular, commercial reception of 300 . He describes such films as Meet the Spartans as highly self-reflexive in their aesthetics of parody and highly ideological in their politics of insinuation, leading to a parodic negotiation - and indeed clash - of reigning cults of masculinity. In creating this successful film (Meet the Spartans grossed $\$ 84$ million), the team of Jason Friedberg and Aaron Selzter often employ extradiegetic humor by forcefully juxtaposing two starkly incongruent cultural epochs and filmic genres. The Greek setting remains the outer framework from which the plot evolves, but the many contemporary references all stem from a different historical time and a different cultural and geographical space, namely current American popular culture and politics. Poole's essay also examines the humor manufactured by contrasting the homosexuality of the Spartans in Meet the Spartans with the homosexuality in 300 , which is described as the habitual practice for the politically distinct Athenians and the culturally othered Persians, personified by Xerxes. In particular, Meet the Spartans queers ancient Spartan homophilia, the institutionalized pederasty between a young warrior and an adolescent boy which was an integral part of a state-ordained pedagogical system critical to a young man's ceremonial masculinization. 300 eclipses the sexual part of the depicted practice of physical initiation, while Meet the Spartans twists the doubly denounced gender politics of 300 (androgyne Persians and pederast Athenians) into an affirmation of the Spartans as being full-fledged queer. It is not the other Greeks or foreign Persians who are "boy-lovers" or "dolled up"; it is the Spartans who are lustily, ludicrously, and sensuously gay. This helps to account for the switch from serious to comic parody, because by setting free the anarchic possibilities of sexual play, a "trans-contextualization" occurs, that is, an inversion as a resignified repetition revealing the pretext's ridiculousness.

Margaret Toscano examines Mark Antony in "The Womanizing of Mark Antony: Virile Ruthlessness and Redemptive Cross-Dressing in Rome, Season Two." Her essay explores the way Roman masculinity functions as a signifier for imperial potency and domination as well as vulnerability and loss. The death of Julius Caesar created the chaotic political situation which demanded of its factional leaders the traditional Roman notions of maleness - the ideal of the strong and "invincible warrior," who penetrates but is not penetrated with both his sword and his penis. Softness 
and vulnerability were not just despised as womanly but presaged the loss of empire. Toscano guides the reader through Antony's political decline by monitoring his gradual orientalization and sexual metamorphosis as he yields to debauchery, drunkenness, and the lack of soldierly discipline. The historically characterized "orientalizing" and "womanizing" of Mark Antony is not simply about the deterioration of a Roman man. It also paradoxically questions the destructive forces of a virile imperialism: the macho Antony appearing as an Egyptian hermaphrodite questions the very notion of imperialism.

The final contribution in this section segues to the one on Mythological Ancients. Elisabeth Bronfen's "Cleoptra's Venus" tracks a long line of celebrities, namely Theda Bara, Claudette Colbert, Vivian Leigh, and Liz Taylor, who all chose Cleopatra as a figure of identification, making her a paradigm of modern femininity. For these female performers the Egyptian queen who herself had played her role as the goddess Isis, declaring herself to be an embodiment of this deity, served as an ancient example that gave coherence to their celebrity image as a modern goddess. They saw in Cleopatra not only a feminine figure of political power, but also a graceful goddess exercising an alluring charm. Particularly appealing was Cleopatra's perception as a culturally hybrid figure. Bronfen demonstrates that this hybridity is exactly what Cleopatra shared with Venus, the goddess of beauty, charm, and seduction. Both were worshipped within a cultural domain in which they were also declared to be foreign. Both stood for a cultural uncanniness which was conceived as part of their seductive power, bringing together Western and Oriental elements. The modern onset of this fad begins with Cleopatra (1917). Here Theda Bara set the visual and dramatic tone for all subsequent film versions, such as Caesar and Cleopatra (1945) with Vivian Leigh and Cleopatra (1963), in which we find an appropriation of the myth of an oriental femme fatale, the orientalist fantasy of symbolist painting, productively fused with the sexual power of the modern women. In the political dimension Bronfen places Cleopatra's Venus in three distinct thematic domains. The first equates the issue of celebrity with a modern form of political charisma. The second points to the deployment of theatrical spectacle in support of political power. The third employs imaginary projection as a tool for not only "subsuming femininity into masculinist self-representations of political power but also serving articulations of feminine self-negotiation."

Mythological Ancients: The ancient mythological settings represented in this volume fall into three generic categories: ancient epic and tragedy and modern fiction, all of them demonstrating the levels of imagery that 
mythology has inspired since antiquity and the diversity of meanings artists and scholars generated through its reception and transformation. The latter category, modern fiction, features the newly invented tales associated with the newly invented warrior princess, Xena.

Andreas Krass in "Over His Dead Body: Love, Friendship, and Kinship in Homer's Iliad and Wolfgang Petersen's Troy" studies a particular kind of male relationship sanctioned throughout traditional literary history. This particularly discursive scenario requires the lamentation of a dead comrade which tends to obviate the taboo of a homosexual relationship. $\mathrm{He}$ compares the relevant passages in Homer, which nowhere suggest that Achilles and Patroclus entertained a sexual relationship, with the numerous passages in Aeschylus, Plato, and Aeschines - as well as the well-known vase painting (Berlin F 2278) - which openly suggest and even discuss the erotic dimension of their amorous relationship. Krass concludes his essay by discussing how Wolfgang Petersen's Troy heterosexualizes Achilles but offers a variant queer interpretation of the film, concluding that the relationship between the two in the film can be understood as homosociality or as homosexuality, depending on whether the audience focuses on the explicit or implicit message of the film.

A second paper on Troy, "Models of Masculinities Facing Trojan Walls: Achilles and Hector and Their Female Partners," analyzes the depiction of masculinities in the archaic world of Troy through two different lenses. First Celina Proch \& Michael Kleu apply Raewn Connell's typology of sociological gender and specifically masculinity forms by identifying Achilles and Hector as representatives of the "hegemonic" type. Then they employ Judith Butler's work on the performative construction of gender (wherein the body fulfills social actions and serves as a production site of gender-defining behaviors) and Laura Mulvey's feministic film theory to analyze the filmic representation of Troy's heroic bodies. Brad Pitt's Achilles, for instance, performs in a feminized style in his tent but is otherwise an exceptional war machine. Finally they explore the correspondences between heroes and their female partners, concluding, in a subtle contrast to the essay by Beigel, that Andromache and Briseis cater on the characters of Achilles and Hector. They conclude that screenwriter David Benioff and director Wolfgang Petersen engender significant identifying potential for their male target groups. That is, they configure Hector as not only the protector and provider of his family but also the modern image of man who confides in his wife and becomes a role model for an adult audience that has achieved something in life worth defending. In contrast, the philosophy of life that Achilles expounds early in the film does not 
include the aspiration for being a family man, so his confrontations with Agamemnon result from intergenerational conflict. However, later in the film he reconsiders on account of his love for Briseis and becomes willing to enter a relationship, now performing in a more modern mode.

Christian Pischel's "Include me out" - Odysseus on the Margins of European Genre Cinema: Le Mépris, Ulisse, L'Odissea" discusses three distinct filmic adaptations of the Odyssey produced during the 1950 and 1960 . Pischel examines the title phrase from Godard's Le Mépris in the context of Homer's Odyssey and Italian peplum films of that era and in doing so suggests that the character of Ulysses and the core of the genre miss each other in multiple ways. As Adorno and Horkheimer pointed out, Ulysses can be read in terms of bourgeois emancipation and as an ambivalent model of modern subjectivity, able to deny itself. The deceitful Ulysses could have been adopted by the genre, but a close analysis does not show Ulysses as a hyperbolic male subject typical of peplum films but reveals rather three different cinematic concepts of the epic: the psychological realism of the big budget production, self-reflexivity of European Art cinema, and the realistic reconstruction of a tangible environment in the Italian television series. Pischel shows that these concepts are in fact closely related to three different notions of gender: it may either be exploited to maintain dramatic oppositions, reflected as a filmic construction of production values, or experienced as an expression of a certain environment. Finally this brings the reader to a specific predicament which Homer's Ulysses raises: a precarious male subjectivity that gains autonomy within melancholic suffering - provocative tension for both genre and gender patterns.

Lada Stevanovic poses a number of probing questions about Pasolini's adaptation of Medea, one of antiquity's most shocking and challenging plays. In "Between Mythical and Rational Worlds: Medea by Pier Paolo Pasolini," she asks how Pasolini adapts Euripidean drama and translates theater into the film, and she traces the adaptation of antiquity to the twentieth century milieu. Focusing in particular on Pasolini's portrayal of the Colchian Medea as the Other functioning as both a foreigner and a woman, she proposes the hypothesis that it is the masculine reaction to her terminating her procreative function that compels her to follow the path to infanticide. In doing so she adopts the male, heroic mode of behavior, thereby identifying with the man who appears to be her model by choosing to act and kill - not traditional modes of response for women in distress. Medea's rebellious reaction belongs as well to the domain of rational and historical linearity in that the heroic mode was the only means by which she could earn respect. With insight she observes that in accordance with 
Pasolini's political orientation she stands up for the non-European, postcolonial Other and all those people who are socially endangered in the twentieth century. It may be that for this reason Pasolini chose a myth about the infanticide Medea, realizing that repression and lack of space in which the Other can react or speak may lead to a radical reaction and catastrophic outcome after which "Nothing is possible anymore," as Medea says in the end of the film, "an act of artistic terrorism."

Xenia Zeiler takes the reader into a different cultural and political spectrum in her essay on "Universal's Religious Bigotry Against Hinduism: The 'Problem' of Gender Roles and a Production Code Arising From the Reception of the Hindu God Krishna in Xena: Warrior Princess." A spinoff of Hercules: The Legendary Journeys, Xena: Warrior Princess followed the formula of the former, but Xena became a feminist and lesbian icon. The plots of the cult television series expanded into a mythological horizon covering a wide variety of historical epochs, religious traditions, and geographical regions. Zeiler's paper analyses the reception of the Hindu God Krishna as an example of 'Indian' or 'Hindu' influences in the specific gender context of the series. The representation of Krishna in the episode, "The Way," created a wave of protest from a number of Hindu organizations based in the United States and India. Zeiler maintains that the chief offense in this context was the aid given by Krishna to the alleged lesbian couple Xena and Gabrielle. This concern with the lesbian subtext of the series and the deviant understanding of gender roles in the end led to the introduction of a production code, a self-imposed censorship by the production management at Universal Studios.

Mythological and Historical Thematics: This section of the book offers four essays that further extend our narrative, chronological, religious, and ethnic parameters by examining films that are not set in antiquity but include significant thematic, allusive, or even narrative elements derived from the classical tradition and worthy of gender and political analysis.

An instructive example of a film to which a thematic analysis can be applied is Disney's Snow White (1939). In her “Ancient Women's Cults and Rituals in Grand Narratives on Screen: From Disney's Snow White to Olga Malea's Doughnuts With Honey," Svetlana Slapšak links Snow White, when she sings and dances with forest animals, to the potnia theron ("Mistress of the Animals") aspect of the goddess Artemis/Diana; her purification of the dwarf's home to the domestic function of Hestia, the goddess of the hearth; and her virginal status to that of both ancient virgin divinities. In the second half of her paper, Slapšak writes about Olga Malea, the contemporary Greek film director, who used Aristophanic motifs and 
women's cults and rituals to approach the subject of pedophilia in Honey and the Pig (Loukoumades me meli, 2005), concluding that the film is so rich in mythical references that is it impossible not to connect it with Marcel Detienne's analysis of the Adonia, an ancient festival during which Athenian women ironically "celebrated" the short-lived male sexuality. Neither Disney's nor Malea's film directly involves texts or imagery of classical Greco-Roman antiquity. However, both of them reference myth, ritual, and cult that empower mythical patterns of thought and narrative, thus serving to construct power and gender relations and make assertions about matters of identity and sexuality.

Almut-Barbara Renger's “Pandora-Eve-Ava: Albert Lewin's Making of a 'Secret Goddess' " investigates how the 1951 film Pandora and the Flying Dutchman integrates the 2700-year old Hesiodic Pandora tradition with Richard Wagner's version of the Flying Dutchman legend. Set in the 1930s along the Spanish Costa Brava, the film introduces the nightclub singer Pandora [Ava Gardner] as a femme fatale incapable of giving love and destructive for all those who fall in love with her. But then she meets Hendrick van der Zee, the Flying Dutchman, in the Bay of Esperanza which recalls the Hesiodic image of "Hope." By the end of the film, Pandora has brought the Dutch captain with whom she has fallen in love Wagnerian redemption. The essay unravels the imagery of the film by examining the most important predecessors of its variegated traditions, including the Hesiodic Pandora and Pabst's Lulu as well as Sigrid Weigel's "sacrificial heroine," and the "diva" of celebrity studies. Instrumental to Renger's critical analysis is that Pandora here once again is constructed as an artificial woman-body to serve as a projection screen for male anxieties about seductive and powerful women, with the result that male dominance is ultimately reaffirmed. Thus, the film displays retrogressive gender stereotypes. In accordance with a patristic tradition, it associates Pandora with Eve, thereby placing her in a Christian context, and finally transforming her into a loving redeemer, adopting along with Wagner's story his gender hierarchy of intellectual male and self-sacrificing woman. This neutralizes Pandora as an active, live femme fatale and reflects cinematically the post-war socio-political return to limiting the roles of women in American society.

Barbara Schrödl in "Phryne Paves the Way for the Wirtschaftswunder: Visions of Guilt and "Purity" Fed by Ancient Greece, Christian Narrative, and Contemporary History," uses the ancient figure Phryne, the best known hetaera of the 4th cent. BC, celebrated for her quick wit and the natural beauty of her face, from an art historical perspective to reflect upon gender relations and political issues in Die Sünderin (The Sinner), 
a famous film of German post-war cinema which contains the first nude scene in German film history. The film follows a conception of gender roles similar to that of Pandora and the Flying Dutchman. It tells the love story of a male artist and his adoring female model Marina [Hildegard Knef], a prostitute who is "reformed" by her love for the incurably ill painter named Alexander. After a brief period of happiness, Alexander is faced with impending blindness, and Marina, at his request, assists him in his suicide, then follows him in death. Breaking several taboos - nudity, suicide, and euthanasia - the film caused a great scandal in the early 1950 . At that time in Germany, the nude scene and the suicide caused negative reactions among both politicians and the Roman Catholic Church. Schrödl reads in the film a complex texture woven between the ancient tradition of Phryne, Christian myth, and memory of the National Socialist past. References to Nazi art weave the love story of the painter and his model into political events, and this transforms the model's ultimate death into a legitimated sacrifice that prepares society to advance to a new era. Schrödl concludes that the allusion to Phryne may have worked as a kind of immunization of the audience against questions regarding the historical events of the Nazi past.

Tal Ilan's essay on "The Talmudic Torah Scholar Beruriah and Israeli Cinema" concentrates on the 2009 Israeli film Beruriah. The film is rooted in the ancient story of the titular figure's mockery of the aphorism, "women are lighthearted." In consequence of this mockery, Beruriah was seduced by a student of her husband, Rabbi Meir, who sent him to prove the statement's justification, and committed suicide when she discovered that her husband was behind this. Told against the backdrop of this story, the film takes place in contemporary Jerusalem, bridging the ancient figure - the only woman represented in the entire corpus of rabbinic literature - and her modern namesake. Issues of a woman's role in Judaism, gender relations, and the seeming need of males to generate and defend power relations, play a role. The film relates the story of an orthodox Torah scholar who wrote a book about Beruriah. The book was subsequently banned and burned in a public demonstration by the orthodox community. Thirty years later his daughter, also named Beruriah, plays out in her life the story of her ancient namesake. Ilan traces the essential source material of the film to the corpus of the medieval French rabbi known commonly today as Rashi, shows how the film integrates the ancient story with issues of religion and society in contemporary Israel, and elaborates on important subtexts and intertexts of the film, such as the practice of book-burning and the story of Adam and Eve in the Garden of Eden, as depicted in Genesis 2-4. 


\section{HISTORICAL ANCIENTS}





\title{
BEN-HUR AND GLADIATOR: MANIFEST DESTINY AND THE CONTRADICTIONS OF AMERICAN EMPIRE
}

\author{
Jon Solomon
}

Of the several hundred films in the Ancient genre, not to mention all the rest of the thousands of popular films released in the last half century, few have been as financially successful, critically and publicly acclaimed, and influential in the popular culture as Ben-Hur (1959) and Gladiator (2000). MGM's (second) cinematic adaptation of General Lew Wallace's novel earned some $\$ 75$ million while costing $\$ 15$ million, won Best Picture and an unprecedented ten additional Academy Awards as well as the New York Film Critics Circle Award for Best Film, and helped to prescribe and reenergize Ancient films of the 1960 s and beyond. ${ }^{1}$ Similarly, Gladiator grossed over \$450 million while costing some \$100 million, won Best Picture and five additional Academy Awards, and has helped to engender a series of Ancients for both the big screen and television. ${ }^{2}$ By any measure employed to categorize popular Hollywood successes, Ben-Hur and Gladiator provide outstanding examples.

At first blush it may seem as if these two landmark blockbusters share in common simply their ancient Roman settings, admirable and heroic protagonists, and spectacular action scenes. Other Ancients produced in the heyday of the 1950s and 196os before and after Ben-Hur seem to

1 Cf. http://www.imdb.com/title/ttoo52618/business. For domestic and international box office details, see Sheldon Hall and Steve Neale, Epics, Spectacles, and Blockbusters: A Hollywood History (Detroit: Wayne State University Press, 2010) 162-163. Action or farcical film representations of galley and chariot sequences include The Three Stooges Meet Hercules (1962), The Fall of the Roman Empire (1964), Robin Hood: Men in Tights (1993), Titanic (1997), Any Given Sunday (1999), and Star Wars: The Phantom Menace (1999).

2 For an overview with bibliography, see Laurence Raw, The Ridley Scott Encyclopedia (Lanham MD: Scarecrow Press, 2009) 136-141. The television legacies are the very successful Spartacus: Blood and Sand (2010) and its sequel Spartacus: Vengeance (2010, 2012) produced by Starz. Allusions to Gladiator in feature films include Shark Tale (2004), Bigger Than the Sky (2005), Larry the Cable Guy: Health Inspector (2006), Pineapple Express (2008), and Finding Bliss (2010). Both Ben-Hur and Gladiator seem to have inspired the Greek gladiatorial/chariot sequence in Bedtime Stories (2008). For a negative perspective, see John D. Christian, Gladiator: Witchcraft, Propaganda, and the Rise of the World Hero (Austin TX: RiverCrest, 2001). 
provide more obvious and closer comparisons with Gladiator. ${ }^{3}$ The reign of the Emperor Commodus provided the historical setting and central villain for Anthony Mann's The Fall of the Roman Empire (1964) long before Gladiator, and the philosophical presence of Marcus Aurelius, played by an established and aged British actor, graced several scenes in both films. ${ }^{4}$ The gladiatorial school, Republican Gracchus, and black gladiator companion in Stanley Kubrick's Spartacus (1960) all re-appear in Gladiator, and both Spartacus and Maximus instigate gladiator-led slave rebellions against the Roman government and are martyred in the process.

In several significant ways, however, Ben-Hur presents equally if not more significant narrative parallels. Both films tell the story of a once prominent and loyal subject of the Roman Empire who falls victim to personal betrayal and politically motivated Roman villainy, loses his beloved nuclear family, is himself extra-judicially imprisoned and enslaved, kills the villain during a huge public entertainment held in a spectacular venue, and is then finally restored to his family. ${ }^{5}$ Most important is that the ultimate result of his struggles, actions, and final triumph is that he helps to revolutionize the entire Roman Empire. ${ }^{6}$ Of course the writers and director of Gladiator consciously avoided the pervasive Christian narrative track of Ben-Hur, and there is no evidence that the writers were modeling their script on the secular elements of Wallace's story either, but the narrative arc of both films defines its protagonist hero by immersing him into a personal jeopardy that is fully resolved only when the much larger cultural and political environment has been revolutionized.

In Ben-Hur the revolution within the larger cultural and political environment means the introduction of Christianity to the Roman world and its legalized acceptance and subsequent adoption three to four centuries later, the effects of which still reverberate in our own world at the out-

3 Cf. the comparisons identified in Martin L. Winkler, ed., Gladiator: Film and History (Malden MA: Blackwell, 2004) esp. 27, 65-66, 127-129, 156-158, and 169-172; for the tiger in the arena and black gladiator in Demetrius and the Gladiators (1954), see 27.

4 Marcus Aurelius is played by Alec Guiness (age 50) in The Fall of the Roman Empire and by Richard Harris (age 70) in Gladiator. The gladiatorial schools belong to Batiatus (Peter Ustinov) and Proximo (Oliver Reed). Gracchus is portrayed by Charles Laughton and Derek Jacobi. The black companions are Draba (Woody Strode) and Juba (Djimon Hounsou).

5 Literally "in this life or the next," in that the various drafts of the Gladiator script differ in their treatment of the protagonist's nuclear family.

6 For the attempt by the producers of Spartacus (1960) at making an equivalent, albeit ahistorical, claim, see Duncan L. Cooper, "Dalton Trumbo vs, Stanley Kubrick: The Historical Meaning of Spartacus," in Martin L. Winkler, ed., Spartacus: Film and History (Malden MA: Blackwell, 2007) 56-64. 
set of the third millennium. In Gladiator the revolution within the larger cultural and political environment means the end of tyrannical rule and the re-introduction of institutionalized trans-regional republican government, which did not take place until, and quite indirectly, the establishment of the American and French republics in the late eighteenth century, the effects of which also still reverberate in our own world. It is a statement of fact to say that Christianity and non-tyrannical forms of government have become prominent in our contemporary world, and it has often been argued further by their proponents, as we will see in our discussion of Manifest Destiny, that Christianity and democratic forms of governments have become and should remain dominant in Western cultures and ideally replace all others. ${ }^{7}$

The historical establishment and ultimate triumph of Christianity and democracy, two of the signature cultural and political aspects of our contemporary world, may describe one of the most important reasons for the success of these two films which, along with their plausible historicity, admirable heroic protagonists, and spectacular action sequences, realistically recreate before the eyes of their mostly Christian, mostly democratic viewers the ancient origins of the modern world they inhabit and - with a number of relatively minor complaints and even major protests - embrace as civilization itself. This does not mean that any but a small part of the huge and varied audience that watches these films is at the time necessarily conscious of either the historical importance of what transpires at the end of the film or the institutional nature of the modern world. Film, as a popular art form, and this applies in particular to extremely successful commercial films, both reflects and reinforces the audience's general consensus. And the filmmakers themselves usually belong to this same consensus, expressing it in their product and consciously marketing it to the audience. During the processes of filming and viewing Ben-Hur and Gladiator, the filmmakers and the general public were sending and receiving this cultural and political consensus, leading to general acceptance and great success.

In this sense both these films represent modern realizations of Aristotelian peripeteia and catharsis compounded with a happy, in fact, triumphant ending. They both introduce to the audience a charismatic and successful protagonist, vividly submerge him (and them) into a hell of maltreatment and mortal peril, and resurrect him (and them) to the level

7 Cf. the discussion of "a secular utopian ideology of universal democracy" in William Pfaff, The Irony of Manifest Destiny: The Tragedy of America's Foreign Policy (New York: Walker \& Company, 2010) xi. 
of heroic victor. The power of the illusion of drama, enhanced greatly by the mechanical, technical, and sensory powers of cinema, combined with the high expectation levels generated by publicity, advertisements, reviews, and less formal communications ("buzz"), realizes the plausible historical story so effectively that a huge percentage of the audience (tens of millions of people) in a relatively short time span find themselves overwhelmed, as if they themselves have participated in the hero's journey and participated in fomenting the revolution. But this glorious conclusion could not resonate thoroughly and pervasively with a very broad audience unless the politics of the film did so as well. A telling counterexample is Michael Moore's Fahrenheit 9/11 (2004), which attracted record box office receipts and was, commercially at least, the most successful documentary ever produced, earning over $\$ 220$ million while costing only $\$ 6$ million. ${ }^{8}$ That was during the summer of 2004. But despite winning over two dozen critical awards, by the following January it was not even nominated for an Academy Award because the politics of its already limited demographics no longer resonated with a sufficient number of voting members, i.e., a general consensus, of the Academy. Indeed, as popular as the political message of the film was during its release, Michael Moore and his film were also accused of being subversive. ${ }^{9}$

Nonetheless, consensus does not mean uniformity. The political relationship between films and their audiences is multivalent and complex. It is multivalent because within the general consensus, individual audience members respond to multiple political stimuli, signals, and flashpoints with an array of suspicions, preconceptions, and misperceptions. ${ }^{10}$ The reception of a film may not accurately reflect the messages the film appears to be sending. Critics, for example, debated for weeks as to whether Steven Spielberg's Saving Private Ryan (1998) was a war film, a pro-war film, or an anti-war film. Spielberg himself was often quoted as saying:11

8 For a critique of the reasons for its commercial success, see Sergio Rizzo, "Why Less is Still Moore: Celebrity and the Reactive Politics of Fahrenheit 9/11," Film Quarterly 59 (2005-2006) 32-39. In general, see Robert Brent Toplin, Michael Moore's Fahrenheit 9/11: How One Film Divided a Nation (Lawrence KA: University of Kansas Press, 2006).

9 E.g. http://mediamatters.org/research/200406140007, accessed October 30, 2011.

10 For the breakdown of the monolithic conception of American ideology, see Robert Kelley, "Ideology and Political Culture from Jefferson to Nixon, The American Historical Review 82 (1977) 531-562.

11 http://business.highbeam.com/3554/article-1G1-21191193/spielberg-war, accessed October 30, 2011. 
It's an antiwar film only in that if you want to go to war after seeing this picture, then it's not an antiwar film.

In this example, while there is little question that Saving Private Ryan is technically exemplary and emotionally powerful, not to mention filled with narrative tension, personal drama, and absorbing action, there is no uniformity or consensus as to the ultimate meaning of the film. ${ }^{12}$ While watching Gladiator, individuals might react differently to Commodus' ability with the sword, the murder of his father, his threat to the Senate at sword point, his desire to please the mob, and even the suggestions of incestuous flirtations with his sister Lucilla, and while someone might approve of, tolerate, or disparage one or more of these political (and gender-political) characterizing sequences, there is little doubt as to whether Gladiator takes a pro-tyranny or anti-tyranny stance. ${ }^{13}$

The complexity in the relationship between the audience and these films evidences itself in the self-contradictory nature of the Americanstyle empire. ${ }^{14}$ Whether they are screening Ben-Hur or Gladiator, theatrical audiences and individual home viewers achieve catharsis through the defeat of the Roman Empire even though a moment's reflection might make them realize that they live within their own modern empire, not to mention that it, too, will some day face its own demise. There seems to be a sort of schizophrenic paradox, which is an integral part of the reception of Ben-Hur and especially Gladiator, that lies deeply embedded within the American psyche, developed throughout the two hundred-plus years of American history. Indeed, the first words of John Carlos Rowe's book on Literary Culture and U.S. Imperialism makes a similar observation: ${ }^{15}$

Americans' interpretations of themselves as a people are shaped by a powerful imperial desire and a profound anti-colonial temper.

12 The summation of Frank J. Wetta and Martin A. Novelli, “'Now a Major Motion Picture': War Films and Hollywood's New Patriotism," The Journal of Military History 67 (2003) 875, concludes that "Private Ryan offers the best of both worlds - an antiwar film that celebrates those who fought the war."

13 For a different approach to the political atmosphere in which Gladiator was produced, see Emily Albu, "Gladiator at the Millennium," Arethusa 41 (2008) 185-204; cf. Peter W. Rose, "The Politics of Gladiator," in Winkler, Gladiator: Film and History, 150-173.

14 The status and even definition of an American "empire" or hegemony is unclear and much discussed, but well beyond the scope of this chapter. For a recent surveys, see William E. Odom and Robert Dujarric, America's Inadvertent Empire (New Haven: Yale University Press, 2004); and Bernard Porter, Empire and Superempire: Britain, America and the World (New Haven: Yale University Press, 2006), who begins (1) by quoting and evaluating Donald Rumsfeld's comment: "We don't do empire."

15 John Carlos Rowe, Literary Culture and U.S. Imperialism: From the Revolution to World War II (Oxford: Oxford University Press, 2000) 3. 
This paradox consists of the simultaneous assumptions that the United States should be isolated from the rest of the world and all its un-American features, and that American lifestyle and ideals are so exceptional that the rest of the world should be Americanized, neutralizing the inevitable antithesis between freedom and empire by calling occupation and domination peace and beneficence. As we are about to see, throughout its two hundred years or more of existence, its two polarities have been expressed by different political parties at different times, or even by the same politician or author in different times or circumstances. Its ultimate effect, however, is to provide intellectual, emotional, and popular means by which a citizen of an empire can loathe empire. ${ }^{16}$

Like the ancient Roman Republic during its initial stages of growth, the new American nation had carved itself out from the territories of indigenous peoples and overseas colonial governments unwilling to surrender their territory to it. Opinions were sharply divided within even George Washington's administration, with Alexander Hamilton championing international economic engagement, much to the frustration of the isolationist Thomas Jefferson and his agrarian ideal. ${ }^{17}$ Washington himself, who first established his military reputation in the colonial French and Indian War (1754-1758) and, of course, defeated the British imperial army, finished his public service by preaching isolationism in his often cited 1796 Farewell Address [36, 40]:

36 The great rule of conduct for us, in regard to foreign nations, is, in extending our commercial relations, to have with them as little political connexion as possible. So far as we have already formed engagements, let them be fulfilled with perfect good faith. Here let us stop.

40 It is our true policy to steer clear of permanent alliances with any portion of the foreign world; so far, I mean, as we are now at liberty to do it; for let me not be understood as capable of patronizing infidelity to existing engagements. I hold the maxim no less applicable to public than to private affairs, that honesty is always the best policy. I repeat it, therefore, let those engagements be observed in their genuine sense. But, in my opinion, it is unnecessary and would be unwise to extend them.

16 For a chronological overview, see Peter J. Kastor, America's Struggle With Empire: A Documentary History (Washington DC: CQ Press, 2010) xvi-xvii.

17 For the traditional analysis, see L.K. Caldwell, "Thomas Jefferson and Public Administration," The Public Administration Review 3 (1943) 240-253. For a more recent analysis, see Lisi Krall, "Thomas Jefferson's Agrarian Vision and the Changing Nature of Property," Journal of Economic Issues 36 (2002) 131-150. 
The next decades brought increased expansion expressed verbally by John Quincy Adams, who as Secretary of State penned the Monroe Doctrine in 1823 , and militarily during the administration of James K. Polk, when from 1846 to 1848 the United States invaded, seized, and occupied half the territory of Mexico, a sizeable tract which is now almost a quarter of the continental United States.

Both of these imperial milestones will impact our study, albeit differently. After serving as president and then as congressman, John Quincy Adams would become an outspoken proponent of the anti-slavery movement and argue successfully on behalf of the escaped Amistad slaves before the United States Supreme Court. His participation in the Amistad affair would be developed as an integral role in Spielberg's 1997 film of the same name. The Amistad screenplay was written by David Franzoni, who also received story and screenplay credit for Gladiator. ${ }^{18}$ Character parallels between the Maximus and John Quincy Adams characters are significant in that both, after initial reluctance, develop into champions of the slave sector of society and, as we have seen, succeed in implementing an important political revolution. As for Polk's Mexican-American War, known as the Intervención or Invasión in Mexico today, one of the young American soldiers who eagerly joined this war of conquest was a teenage lieutenant from Indiana, Lew Wallace. Here we have a historical person who fought for empire but would decades later invent the fictitious character who would symbolically defeat the Roman Empire. We will have more to say about both Franzoni and Wallace after further examination of the American self-contradictory attitude towards empire.

John Quincy Adams himself, two years before writing what has become a permanent declaration that the United States will intervene in any attempt to occupy any part of the Western hemisphere, made it equally clear that the United States would not lend a hand to (apparently) anyone. At the time this included the Greek insurrection to overthrow the centuries-old Ottoman occupation, even though the United States government was lending its moral support to the Greek War of independence and American private citizens were pouring vast sums of money into it. ${ }^{19}$

\footnotetext{
18 Franzoni also received producer credit along with Douglas Wick and Branko Lustig.

19 For Monroe's reluctance to support Greece, see Richard H. Immerman, Empire for Liberty: A History of American Imperialism from Benjamin Franklin to Paul Wolfowitz (Princeton: Princeton University Press, 2010) 88.
} 
In the foreign policy speech Adams made to the U.S. House of Representatives on July 4, 1821, he fully expressed his concept of isolationism: ${ }^{20}$

Wherever the standard of freedom and Independence has been or shall be unfurled, there will her heart, her benedictions and her prayers be.

But she goes not abroad, in search of monsters to destroy.

She is the well-wisher to the freedom and independence of all.

She is the champion and vindicator only of her own....

[America's] glory is not dominion, but liberty. Her march is the march of the mind. She has a spear and a shield: but the motto upon her shield is, Freedom, Independence, Peace. This has been her Declaration: this has been, as far as her necessary intercourse with the rest of mankind would permit, her practice.

When Polk led the country to one of its most ambitious imperial enterprises, the reasons he cited in his special message to Congress of May 11, 1846 were attributed to failed diplomacy, accusing Mexico of rejection, insult, and injury, and then killing American soldiers on American soil. The purpose of the war, he said, was: ${ }^{21}$

Called upon by every consideration of duty and patriotism to vindicate with decision the honor, the rights, and the interest of our county.

But there was considerable dissent which saw through the diplomatic legal posturing. ${ }^{22}$ The Whigs turned on the Democrat Polk with a vengeance, accusing him of starting the war illegally. Among them was Abraham Lincoln, then a one-term congressman from Illinois, who within a month of his arrival in Washington was vocally supporting the Ashmun amendment that declared that the war had been "unconstitutionally commenced by the order of the President." 23 Adams, the isolationist, opposed

20 John Quincy Adams, "Speech to the U.S. House of Representatives on Foreign Policy," July 4, 1821, accessed October 30, 2011, http://millercenter.org/scripps/archive/speeches/ detail $/ 3484$.

21 Christopher Conway, ed., The U.S.-Mexican War: A Binational Reader (Indianapolis: Hackett Publishing Company, 2010) 58-61.

22 John H. Schroeder, Mr. Polk's War: American Opposition and Dissent, 1846-1848 (Madison: University of Wisconsin Press, 1973); Frederick Merk, "Dissent in the Mexican War," in Samuel Eliot Morrison, Frederick Merk, and Frank Freidel, eds., Dissent in Three American Wars (Cambridge: Harvard University Press, 1970) 33-63. Cf. Scott A. Silverstone, Divided Union: The Politics of War in the Early American Republic (Ithaca NY: Cornell University Press, 2004) 157-201.

23 G.S. Borit, "Lincoln's Opposition to the Mexican War," Journal of the Illinois State Historical Society (1908-1984) 67 (February, 1974) 79-80. For the full and additional text, see Christopher H. Pyle and Richard M. Pious, The President, Congress, and the Constitution: Power and Legitimacy in American Politics (New York: The Press Press, 1984) 298. For the Ashmun amendment, see Morrison, Merk, and Freidel, Dissent in Three American Wars, 49: 
the war as well, yet he, with Lincoln, voted repeatedly to fund it. ${ }^{24}$ Adams' stance against slavery as well as the Mexican War further expressed the paradox within. Two different biographers, William Weeks and Samuel Bemis, noted that: 25

Predictably, this stand generated charges of treason and disloyalty. Adams' intense opposition to the spirit and tactics of Manifest Destiny during this period makes all the more ironic his earlier role in generating and advancing the expansionist fever. As secretary of state, Bemis writes, Adams 'had all but coined the magic making phrase Manifest Destiny.'

It was just two years earlier that the newspaper essayist John Lewis O'Sullivan popularized the phrase "Manifest Destiny":26

And that claim is by the right of our manifest destiny to overspread and to possess the whole of the continent which Providence has given us for the development of the great experiment of liberty and federated self-government entrusted to us.

This famous phrase has been much parsed by scholars of American history, and they have made it clear that the phrase described neither an entirely new concept nor a fully comprehensive nor enduring one. ${ }^{27}$ Nonetheless, it has come to symbolize the idea that the impetus for America's transcontinental expansion towards the Pacific Ocean - and then beyond - was open, beckoning, and inevitable. ${ }^{28}$ From Governor Winthrop of Massachusetts in 1630, who claimed that "the Lord will be our God and delight

“... That such a war of conquest, so hateful in its objects, so wanton, unjust and unconstitutional in its origin and character, must be regarded as a war against freedom, against humanity, against justice, against the Union...."

${ }^{24}$ Frederick Merk, Manifest Destiny and Mission in American History: A Reinterpretation (New York: Alfred A. Knopf, 1963) 95-96.

${ }^{25}$ William Earl Weeks, John Quincy Adams and American Global Empire (Lexington KY: The University of Kentucky Press, 1992) 194, citing Samuel Flagg Bemis, John Quincy Adams and the Union (New York: Alfred A. Knopf, 1956) 481.

26 The passage from the article "Annexation," United States Magazine and Democratic Review 16 (July-August, 1845) $5^{-10}$, was unsigned. Attribution for the phrase is usually given to the editor, John O'Sullivan, but more recently attention has been paid to Jane McManus Storm Cazneau, for which see Linda Hudson, The Mistress of Manifest Destiny: A Biography of Jane McManus Storm Cazneau, 1807-1878 (Austin: Texas State Historical Associantion, 2001) 45-68.

27 E.g. Merk, Manifest Destiny and Mission in American History, 60.

28 Among others, Anders Stephanson, Manifest Destiny: American Expansionism and the Empire of Right (New York: Hill and Wang, 1995), xi-xii, suggests that once the transcontinental mission was fulfilled and American territorial expansion spread overseas, the phrase "manifest destiny" no longer applied. Nonetheless, in his speech of October 11, 1898 at Cedar Rapids, Iowa, President William McKinley said that the Philippine occupation "calls forth sentiment of gratitude to divine Providence for those favors which he has 
to dwell among us as his own people" in our "City upon a Hill," to President William McKinley, who in 1898 sought to "civilize and Christianize and by God's Will do our very best by [the Filipinos]," the expansionist and imperial policies self-justified by the Monroe Doctrine also took on the imprimatur of the Christian god. ${ }^{29}$ This schizophrenic attraction to and resistance against territorial expansion and the creation of empire is still evident in the contemporary political arena. When Gladiator was in production in 1999, candidate George W. Bush criticized President Bill Clinton for his nation-building efforts. ${ }^{30}$ Two years later he established the Bush Doctrine of preemptive war and regime change, realized by his invasions of Afghanistan and Iraq, lengthy occupations, democratized elections, and permanent military and diplomatic bases.

Lew Wallace provides a different perspective in that he was a relatively powerless witness but full participant during the most important period of American imperial expansion. When Wallace was five years old, in 1832, his father organized the local militia for the Black Hawk War, helping to instill in the youth a passion for war against the Other. But his experience in the Mexican war forced him to confront the legacy of the Spanish Empire and sympathize instead with the indigenous peoples. Years later he would set his first published novel, The Fair God (1873), during the last days of the Aztec Empire of pre-colonized Mexico. The epigram on the title page of The Fair God makes clear at the outset his detestation of the results of foreign conquest by quoting Draper's History of the Intellectual Development of Europe: ${ }^{31}$

manifested unto us." Cf. Robert P. Saldin, War, the American State, and Politics Since 1898 (New York: Cambridge University Press, 2010) 44.

${ }^{29}$ For Winthrop, see Francis J. Bremer, John Winthrop: America's Forgotten Founding Father (New York: Oxford University Press, 2003) 179. For the latter, see Quentin R. Skrabec, William McKinley: Apostle of Protectionism (New York: Algora Pub., 2008) 161; and John B. Judis, The Folly of Empire: What George W. Bush Could Learn from Theodore Roosevelt and Woodrow Wilson (New York: Lisa Drew/Scribner, 2004) 4. For his statement: "Territory sometimes comes to us when we go to war in a holy cause," see Saldin, War, the American State, and Politics Since 1898, 44. A similar sentiment was expressed the previous year in Rudyard Kipling's "The White Man's Burden." Cf. Robert C. Hildebrand, Power and the People: Executive Management of Public Opinion in Foreign Affairs, 1897-1921 (Chapel Hill NC: University of North Carolina Press, 1981) 40.

30 "The 2000 Campaign: 2nd Presidential Debate Between Gov. Bush and Vice President Gore," The New York Times (October 12, 2000) A22: "I don't think our troops ought to be used for what's called nation building" (http://zfacts.com/p/136.html). For details, see Alexander Moens, The Foreign Policy of George W. Bush: Values, Strategy, and Loyalty (Aldershot UK: Ashgate, 2004) 37.

${ }^{31}$ Lew Wallace, The Fair God: Or, the Last of the 'Tzins - A Tale of the Conquest of Mexico (Boston: James R. Osgood and Company, 1873), title page; derived from John 
It has been Spain's evil destiny to ruin two civilizations, Oriental and Occidental, and to be ruined thereby herself ... In America she destroyed races more civilized than herself.

Clearly, long before Wallace conceived of the story line of his next novel, Ben-Hur: A Tale of the Christ (1880), he developed a profoundly negative attitude towards the legacy of aged, foreign empires. Towards the end of The Fair God [7.4], which features the demise of the Aztec culture at the hands of the invading Spanish conquistadores, Montezuma approaches death. In doing so he makes a prophecy for his people and their future: ${ }^{32}$

I see the tribes newly risen, like the trodden grass, and in their midst a Priesthood and a Cross. An age of battles more, and, lo! The Cross but not the priests; in their stead Freedom and God.

There could be no more succinct expression of the two constants of the doctrine of manifest destiny, democratization and Christianization, than the motto "Freedom and God" - especially put into the mouth of the pagan chieftain Montezuma. It was this same formula, bolstered by Wallace's personal Christian revelation in 1876 , that would provide the substructure of the story of Ben-Hur and its spectacular film renditions many decades later. ${ }^{33}$

Though the United States has been struggling with the concept of increasing its empire for two centuries, this has not stopped its progress in building the empire. Of course many of the shifts in polarities we have surveyed could be attributed variously to diplomatic posturing, campaign rhetoric, demagoguery, changes in regional or distant conditions, "entangling alliances," hypocrisy, lack of serious conviction, or just political "flip-flopping." But the fact remains that these men were all in various degrees part of or working for the government. They were the ones who promulgated such political philosophies and implemented them as policies. This leaves the citizenry, or, more important for the present study,

William Draper, History of the Intellectual Development of Europe (New York: Harper \& Brothers, 1863) 448.

32 Ibid., 459-46o.

33 When the United States declared war on the remnants of the Spanish Empire in the Spanish-American War in 1898, the retired Civil War general volunteered his services, but once he was informed of the seizure of territories in the Pacific and Caribbean, he joined the isolationist and anti-imperial movement and then drafted an (unsuccessful) amendment to the U.S. Constitution that would forbid wars of unprovoked aggression and occupation. The like-minded Mark Twain, when asked if he was an anti-imperialist, responded: “Well, I am. A year ago I wasn't." (as quoted in Rowe, Literary Culture and U.S. Imperialism, 124). 
the common "folks" packing movie theaters to see the likes of Ben-Hur and Gladiator, less informed. Far from forming or implementing foreign policy, the common citizenry would learn about it at best through government propaganda or second hand sources, but more likely they were only superficially informed, or misinformed, or largely ignorant, and even then what information they received would be greatly colored by the aforementioned individual suspicions, preconceptions, and misconceptions about both the government and its foreign encounters. ${ }^{34}$ Because of this philosophy/policy/information gap, the populace embraces both isolationist and interventionist extremes but does not have the capability of fully comprehending the paradox, negotiating its nuances, or calculating its benefits and detriments. As a result, most of populace is unaware of or denies the existence of an American empire. The natural tendency to feel terror and pity for the dramatized rebel ("underdog") prevails even if from the imperial perspective Judah Ben-Hur and Maximus are, like Spartacus, dangerous insurgents ("terrorists").

Complicating audience reception of the politics of an epic blockbuster production is that it incorporates the ideas and contributions of a dozen or so central artists - producers, writers, director, lead actors, cinematographer, art director, composer, et al. Throughout the daily grind, mounting costs, and intense pressures of the writing, pre-production, shooting, and post-production steps of making a high-profile, highly anticipated film - which consumed five years for Ben-Hur and two for Gladiator initial plot lines, themes, messages, and important dialogue go through repeated reevaluations and adjustments, and changes are made which effect the political and cultural reading of the final release. In Franzoni's 1998 draft of Gladiator, Maximus (here called Narcissus) is tormented by both the Roman Senate as well as the emperor. ${ }^{35}$ The initial draft characterizes Narcissus as a celebrity who makes endorsements for an olive oil

34 A May 4, 1999 Gallup poll on Kosovo found that only 17\% of Americans surveyed thought engaging in military action in Kosovo was more important than health care, education, or crime. But half also believe in the precepts of manifest destiny: a 1999 USA Today/CNN/Gallup poll found that $48 \%$ believed that an attack on Iraq would achieve "significant goals" and that 70\% believed the attack should remove Saddam Hussein. And a Gallup poll published July 17, 2009, found that although $58 \%$ of the American public now think invading Iraq was a mistake, $56 \%$ think we have "made progress," http://www .huffingtonpost.com/2009/07/17/gallop-poll-iraq-war-a-mi_n_237875.html, accessed October 30, 2011.

35 For the development of the Gladiator script, see David S. Cohen, Screen Plays: How 25 Scripts Made it to a Theater Near You - For Better or Worse (New York: HarperEntertainment, 2007) 19-33; and Jon Solomon, "Gladiator from Screenplay to Screen," in Winkler, Gladiator: Film and History, 1-15. 
company, portraying him more as a commercial advocate than a political rebel. Furthermore, the "Deleted Scenes" of the Gladiator DVD include a scene with Christians, which would have drastically diluted the political themes of the release version.

Similarly, in Wallace's novel Judah Ben-Hur intentionally arranges to crash Messala's chariot, thereby humbling, defeating, and disabling the symbol of the Roman Empire. Messala is left a broken man, but he continues to harass Judah for years, as does the Roman occupational government of Pontius Pilate. By the time this evolves into the release version of the 1959 film, Messala attacks Judah with his whip and serrated axle hub, making Judah the innocent victim of Messala's villainy and killing off Messala - and the villainy of Rome - long before the conclusion of the narrative. Also, Wallace's Judah Ben-Hur was a teenage, hot-headed political rebel modeled to a certain extent after the Essene Zealot Judas of Galilee described by Josephus. ${ }^{36}$ His expressed desire throughout the novel was to become a soldier who would oust the Romans from Judea. William Wyler instead cast Charlton Heston, already in his mid-forties, representing a mature and contemplative adult. The cinematic Judah's hatred of Messala almost completely overshadows his hatred for Roman rule. Indeed, for the most part the 1959 Judah is portrayed as a politically neutral witness to the passion of Christ.

Nonetheless, some evidence of the rebellious aspect of Judah's character remained even in the shooting-script stage of production. This version of Judah's last interview with Pontius Pilate, the Roman governor, is one of the sections that specifically connects Judah to the anti-Roman rebellion run by Sheik Ilderim and Simonides. It also allows Judah to threaten the Roman governor. But both parts of this scene were edited out of the release version of the film: ${ }^{37}$

Pilate

In Rome you are, and you can remain, an honored, influential man.

Ben Hur

I prefer my own people.

Pilate

Here, you are in danger. In the games you drove the chariot of Sheik Ilderim. He plans a revolt of the desert tribes against Caesar. In your house there is

\footnotetext{
36 Josephus Jewish War 2.119.

37 This January, 1958 version of the script is housed at the Herrick (Academy of Motion Picture Arts and Sciences) Library.
} 
an old man named Simonides, who plots against Rome. He is your slave and your friend. If you cast in your lot with the Jews and the Arabs you will be destroyed.

\section{Ben Hur}

The Romans have a sense of honor, my lord. Is it not better to die honorably with my own nation than to live in harmony in luxury in Rome while you make slaves of my countrymen?

\section{Pilate}

Gratus left Judea in turmoil. A rabble-rouser called the Messiah goes about Galilee stirring up rebellion. You are a Jew and a prince. If you stay here you will be blotted out with the others.

\section{Ben Hur}

A great many will die, Lord Pilate, and they will not all be Arabs and Jews! I take pleasure in that thought! If we die we shall make sure of some Romans to share our graves!

In the release version Pilate attempts to eliminate Judah's anti-Roman sentiment by reasoning with him. Judah, in turn, is now more of Jewish victim of Rome than a threat to Rome. Rather than being characterized as a rebel leader threatening Pilate, Judah is described as the hero and god of the rabble who may himself become collateral damage:

\section{Ben Hur}

There are other voices.

\section{Pilate}

The voice, for instance, of Arrius, waiting for you in Rome. He would tell you, if I may speak in his place, not to crucify yourself on a shadow such as old resentment or impossible loyalty. Perfect freedom has no existence. The grown man knows the world he lives in, and for the present, the world is Rome. Young Arrius, I am sure, will choose it.

\section{Ben Hur}

I am Judah Ben Hur.

\section{Pilate}

I crossed this floor and spoke in friendship as I would speak to Arrius, but when I go up those stairs, I become the hand of Caesar, ready to crush all those who challenge his authority.

There are too many small men of envy an ambition who try to disrupt the government of Rome. You have become the victor and hero to these people. They look to you, their one true god, as I called you. If you stay here, you will find yourself part of this tragedy.

\section{Ben Hur}

I am already part of this tragedy... 
Pilate

Even for the sake of Arrius, I cannot protect you from personal disaster if you stay here. You are too great a danger.

The "rabble" to which Pontius Pilate refers plays a similar role in Gladiator, but here Franzoni identified "the mob" as a critical player in the political balance of his Roman Empire. His inspiration for the use of the unflattering term "the mob" was the novel he had read decades earlier, Daniel P. Mannix' Those About to Die [a.k.a. The Way of the Gladiator]: ${ }^{38}$

To the Roman mob...the circus was the only panacea for its troubles... Here he was able to meet with other freemen, feel a sense of unity as he sat with his faction cheering a certain chariot team, and impose his wishes on the emperor himself, for, as the Romans themselves said, "In the circus alone are the people rulers." ${ }^{39}$

In an interview with film reporter David Cohen, Franzoni pinpointed the whims, preferences, and wishes of the general populace as the most dangerous components of the Roman Empire. As Cohen narrates:

The common people, in the form of the Colosseum audience, are the ultimate tyrant, more powerful than even the emperor. "You can provide what this animal needs, you can feed the animal, but in the end it'll eat you," said Franzoni. The real power struggle, then, is the battle for the hearts of a fickle public.

If that sounds a bit like a description of the United States at the dawn of the new millennium, that is no accident.

"I see this as the America of tomorrow. Right now, America is the land where everyone has the right to their opinion. Tomorrow, America will become the country where everyone's opinion is equally right. That's the politically correct syndrome. That will then, since the Constitution can't cope with that concept, begin the unwinding of the concept of the republic. That's what happened in Athens, and Rome became that. I think eventually we'll get there. I honestly do believe that."

"There are so many elements of ancient Rome during that period that are almost identical to America today that it's almost unavoidable," said Franzoni. "Street gangs dominating the inner cities. Politicians using the media,

38 Daniel P. Mannix, Those About to Die: The Way of the Gladiator (New York: ibooks, 2001) 4-5.

39 Cf. the comments on Suetonius Life of Domitian 4, in William Stearns Davis, ed., Readings in Ancient History: Illustrative Extracts from the Sources (Boston: Allyn and Bacon, 1913) II, 194: "Despite their control of the army and the subservience of the Senate, the average Emperor quailed before the hootings and ill will of the Roman mob. Thus Domitian (81-96 AD), a bad and tyrannical Caesar, tried to win popularity by providing the idle masses of the capital with their favorite games and arena massacres." 
entertainment, to control the masses. The concept that the masses can be controlled in a thoughtless manner. That very idea is becoming more and more clearly American. That was a core idea of Roman politics; the idea that their voices can be corralled to sing as one is definitely Rome after the Republic."

"It just seemed to me that Commodus represented the politician of tomorrow - we're sort of getting there now - who exploits the media absolutely to control the public."

Franzoni specifically relates the ancient Roman populace to our contemporary society, a clear indication that this was the central political scenario he was attempting to create, although it was ultimately relegated to just a handful of lines in several scenes. Then again, in contemporary popular cinema that is all that is required to convey an important theme or message. Commenting on the popularity of Commodus, for instance, Senator Gracchus remarks:

He is cleverer than I thought ... I think he knows what Rome is. Rome is the mob. He will conjure magic for them, and they will be distracted. He will take away their freedom, and still they will roar. The beating heart of Rome is not the marble of the Senate. It is the sand of the Colosseum. He will give them death, and they will love him for it.

But how would this be a message that would resonate with the American audience, or, for that matter, any audience in a democratic society? It seems to be an insultingly anti-democratic policy issued from the lips of the one Roman senator supporting Maximus in his scheme against the tyranny of the emperor who holds power predominantly because he controls the same populace by simply manipulating their base desire to watch blood-sport spectacles. Isolating this perspective by itself within contemporary American political categories, this falls into the "conservative" sector, that is, anti-democratic and pro-oligarchic, assuming that the Roman senate represents landed, pedigreed aristocracy.

There are many answers. Indeed, there are probably millions of answers. That is, as with reference to the variants described above, the audience is fragmented. Each viewer either comprehends the importance of the Roman mob or not, or has a strong opinion about oligarchy or not, or is envious of the moneyed class or not, or would like to have a head of state whose first act would be to provide a 150-day festival or not, and so on, already dividing the audience into many parts. Of course many audience members are probably not thinking politically at all, or at least not in an analytical manner. They may be satisfied enough to see that the heroic/ movie-star protagonist has been mistreated by the unlikeable villain, 
and think that any means to get revenge is acceptable. They may hate all government authority figures, or whatever political perspective a Roman emperor might represent. They may particularly dislike their own United States senator(s) - or their boss - and cannot move beyond that association. They may be trying to recall the name of the actor or what role in what film he played that they cannot at the moment remember. They might just be thinking that men look silly and undignified in togas. They may be ignoring the dialogue entirely and focusing on the visuals. They might be thinking about their job, or their date, or dinner, or sex, or a myriad of other subjects, details, or distractions. Thus the audience is fragmented even further.

Even those that are focusing on the political perspective will not comprehend the scene in the same way. Page after page, the essays in this book demonstrate a variety of opinions. Scholars and critics analyze films in minute detail, but political opinions at every level of education and in the entire gamut of professions and social groupings are just as numerous as the people who express them, even if they fall into general categories - conservative, libertarian, liberal, progressive, and all their mixtures, hybrids, and fringe perspectives. But no commercial contemporary epic filmmaker would assume that their film would be a success if they catered to just one particular perspective. ${ }^{40}$ There is no Michael Moore or Leni Riefenstahl of the contemporary commercial blockbuster genre. If Oliver Stone could be considered a counterexample, his Alexander clearly suffered at the American box office because of the film's purported homoerotic explicitness.

One way or the other, audiences ignore the paradox. As we said at the outset, the huge success of films like Ben-Hur and Gladiator requires an extraordinarily broad appeal, one that overarches millions of the aforementioned types of individual opinions and reasons for rejection. The fact that by the conclusions of these two films the world into which tens of millions of viewers have been enticed and then captivated for several hours with various and exemplary cinematic structures and techniques has been transformed from pagan villainy to Christian redemption, or from political tyranny to a representative republic, becomes an emotional triumph for most of them. Like a public political rally or campaign event, the numerous perspectives and opinions that individuals would normally

40 For an overview, see Arthur S. De Vany, Hollywood Economics: How Extreme Uncertainty Shapes the Film Industry (London: Routledge, 2004). 
use as barriers or at least filters to the messages being broadcast by the film no longer function correctly. ${ }^{41}$ They have been overwhelmed, or silenced, even if temporarily. As if swayed by effective political rhetoric or compelling propaganda, the audience for the most part accepts the setting and situation, the narrative, the characters, and the resolution of the plot. Public euphoria abounds. Criticisms are unexpected, discouraged, dismissed, even ridiculed. Praise is effusive and ubiquitous. For both BenHur and Gladiator there were theatrical re-releases as well in 1969 and late 2000, respectively. The uplifting sensation is revisited at the Academy Awards ceremony and again at the home premier. For Ben-Hur there was also the 1971 network television premier, which attracted the third largest audience ever at that time, and this was twelve years after its initial theatrical release. ${ }^{42}$

The exceptional level of success these two films reached was not coincidence. The public had been prepared for years, for neither film was released into a cinematic or cultural vacuum. The post-World War II success of Cecil B. DeMille's Samson and Delilah in 1949 initiated a renascence of epic films set in antiquity, most notably MGM's screen adaptation of Quo Vadis in 1950, followed by the first CinemaScope release, The Robe (1953) and its sequel Demetrius and the Gladiators (1954), as well as Warner Brothers' Helen of Troy (1956), and Joseph E. Levine's American release of Hercules (Le fatiche di Ercole - 1958) for the drive-in and matinee demographics. Gladiator followed in the wake of Hercules: The Legendary Journeys ([1994] 1995-1999) and Xena: Warrior Princess (1995-2001), the two most popular syndicated television shows in the world in the late 1990s, which in turn helped to inspire the production of the Hallmark/NBC The Odyssey (1997) and the Disney animated feature Hercules (1997). As the genre expanded and gathered popular momentum, the general population was in that sense being prepared for a high-profile mega-hit, which they found in Ben-Hur and Gladiator. So far as we know, when Spielberg gave

41 Murray Smith, "Film Spectatorship and the Institution of Fiction," The Journal of Aesthetics and Art Criticism 53 (1995) 113-127, presents a survey of approaches to understanding film spectatorship and the relationship between illusion, film, and other genres of art.

42 CBS broadcast the film on Sunday, February 14, 1971. Running five hours with commercial breaks, it preempted 6o Minutes. This airing received the largest audience (37.1 rating/56 share) to date for a movie aired on television. Cf. http://www.mrpopculture.com/ files/html/feb20-1971, accessed December 16, 2011. 
Franzoni approval to write the Gladiator script he intuitively recognized this. For Ben-Hur we have the recorded statement of a studio executive: ${ }^{43}$

There was a waiting market for a well-made spectacle.

Audiences were also prepared politically. Both films appeared in periods of unparalleled peace and prosperity in the United States and much of the world. The success of the democratic system was assumed in "the West" and assailed in "the East." 44 In the late 1950 s the Soviet Union and its satellites were held up as paragons of tyranny and evil. Weekly American television programming offered an extraordinary number of Westerns in which the de rigeur plot required the protagonist hero to capture or kill the villain. The peak came in 1958/1959, coincidental with the filming of Ben-Hur, when there were twenty-four adult Westerns programs appearing on prime-time television every week, twelve of them rated in the top twenty-five shows, and seven of them in the top ten, drawing audiences of some fifty million nightly. ${ }^{45}$ Similarly, in the 1990 s the most frequent plot type in Hercules: The Legendary Journeys and Xena: Warrior Princess had the heroic protagonist liberate a village terrorized by a tyrant or tyrannical monster. The Hercules/Xena formula fed into and was fed by the propagandized image the United States fostered during the Clinton era, as military force was applied to ethnic turmoil in Kosovo and Iraq, and the concept of "nation building" served as a motto of American military and commercial expansionism as the corporate network media repeatedly reconfirmed the presence and pleasures of peace and prosperity, with a steady diet of positive spin and propaganda. ${ }^{46}$ The "consensus" in the United States

43 Variety, December 2, 1959, 13. Cf. Hall and Neale, Epics, Spectacles, and Blockbusters, 162.

44 For Edward Said and the "bipolar" perspective, see Davidson, "Christian Zionism as a Representation of American Manifest Destiny," 157-158; cf. Ikechi Mgbeoji, "The Civilised Self and the Barbaric Other: Imperial Delusions of Order and the Challenges of Human Security," Third World Quarterly 27 (2006) 855-869.

45 Michael T. Marsden and Jack Nachbar, "The Modern Popular Western: Radio, Television, Film and Print," in Western Literary Association, A Literary History of the American West (Forth Worth TX: Texas Christian University Press, 1987) 1267. Cf. Richard Aquila, Wanted Dead or Alive: The American West in Popular Culture (Urbana IL: University of Illinois Press, 1996) 160.

46 The May 5, 1999 report from F.A.I.R. (Fairness \& Accuracy in Reporting), for example, showed that $45 \%$ of interviewees for reports on the Kosovo bombing consisted of current or former U.S. government and military officials, NATO representatives and NATO troops, and another $18 \%$ were Albanian refugees and KLA spokespeople; only $6 \%$ were critical of the bombing. This survey included interviews on PBS' NewsHour, which appeals traditionally to a more liberal demographic. 
during the 1950s and 1990s was that the American formula of capitalistic democracy within a secular but predominately Christian society was not only successful but would ultimately prevail over contemporary tyrannies, whether by withstanding, defeating, or replacing them. ${ }^{47}$

The nineteenth-century concept of manifest destiny along with the accompanying concept of American exceptionalism, while rarely acknowledged among the general populace, resurfaces in the twentieth-century American psyche when the Other seems to be in need of Americanization. It does not matter whether the Other is a monstrous village tyrant or the Roman Empire. The cinema audience intuitively senses that this is the triumph of good over evil, the same Manichean duality to which George W. Bush referred in his final message to the American people in his capacity as president and commander-in-chief. ${ }^{48}$ In this sense, manifest destiny along with American exceptionalism can blind the American populace to the idea that their empire is the modern equivalent of the Roman Empire, and this trumps any notion that their empire might have similar faults or suffer the same fate, or that there should be a functioning antithesis between freedom and empire.

Lastly, it is important to observe that many of the artists who contributed to both Ben-Hur and Gladiator were born, were citizens of, or lived outside of the United States, e.g., Stephen Boyd, Jack Hawkins, Ridley Scott, Russell Crowe, and William Nicholson. Indeed, by design British actors were cast as the Romans in Ben-Hur. This does not change the equation. The American film industry has been a magnet for foreign talent almost since its inception, and the style, motifs, and themes of American cinema have long been established and successful worldwide. It is not uncommon for foreigners and immigrants to embrace American values wholeheartedly because they sought out employment in the American film industry and/or are themselves products of Americanization. ${ }^{49}$ In this narrow

47 Cf. Davidson, "Christian Zionism as a Representation of American Manifest Destiny," 157-169.

48 Bush's Farewell Address was delivered on January 15, 2009: "I have often spoken to you about good and evil. This has made some uncomfortable. But good and evil are present in this world, and between the two there can be no compromise. Murdering the innocent to advance an ideology is wrong every time, everywhere. Freeing people from oppression and despair is eternally right. This nation must continue to speak out for justice and truth. We must always be willing to act in their defense and to advance the cause of peace." Cf. "A Somber Bush Says Farewell to the Nation," The New York Times, January 16, 2009, 21.

49 On the origins of the Americanization process in the 1910s, see Richard Abel, Americanizing the Movies and "Movie-Mad" Audiences, 1910-1914 (Berkeley: University of California Press, 2006) 3. His discussion (25) of the first films "to find favor with the American 
sense it also includes most non-American audiences. The very nature of American global imperialism is that it promotes itself like an American film - alluring appearance, brawny power, large scale, and the ultimate triumph of good over evil. Ben-Hur and Gladiator both captured and packaged all this in epic proportions fit for popular consumption.

\section{Works Cited}

Abel, Richard. Americanizing the Movies and "Movie-Mad" Audiences, 1910-1914 (Berkeley: University of California Press, 2006).

Adams, John Quincy. "Speech to the U.S. House of Representatives on Foreign Policy." (July 4, 1821).

Albu, Emily. "Gladiator at the Millennium," Arethusa 41 (2008) 185-204.

_. "Annexation," United States Magazine and Democratic Review 16 (July-August, 1845) $5^{-10 .}$

Aquila, Richard. Wanted Dead or Alive: The American West in Popular Culture (Urbana IL: University of Illinois Press, 1996).

_ . "A Somber Bush Says Farewell to the Nation," The New York Times (January 16, 2009) A21.

Bemis, Samuel Flagg. John Quincy Adams and the Union (New York: Alfred A. Knopf, 1956).

Borit, G.S. "Lincoln's Opposition to the Mexican War," Journal of the Illinois State Historical Society (1908-1984) 67 (February, 1974) 79-100.

Bremer, Francis J. John Winthrop: America's Forgotten Founding Father (New York: Oxford University Press, 2003).

Caldwell, L.K. "Thomas Jefferson and Public Administration," The Public Administration Review 3 (1943) 240-253.

Christian, John D. Gladiator: Witchcraft, Propaganda, and the Rise of the World Hero (Austin TX: RiverCrest, 2001).

Cohen, David S. Screen Plays: How 25 Scripts Made it to a Theater Near You - For Better or Worse (New York: HarperEntertainment, 2007).

Conway, Christopher, ed., The U.S.-Mexican War: A Binational Reader (Indianapolis: Hackett Publishing Company, 2010).

Cooper, Duncan L. "Dalton Trumbo vs, Stanley Kubrick: The Historical Meaning of Spartacus," in Martin L. Winkler, ed., Spartacus: Film and History (Malden MA: Blackwell, 2007) 56-64.

Davis, William Stearns, ed., Readings in Ancient History: Illustrative Extracts from the Sources (Boston: Allyn and Bacon, 1913).

De Vany, Arthur S. Hollywood Economics: How Extreme Uncertainty Shapes the Film Industry (London: Routledge, 2004).

Draper, John William. History of the Intellectual Development of Europe (New York: Harper \& Brothers, 1863).

Hall, Sheldon and Steve Neale, Epics, Spectacles, and Blockbusters: A Hollywood History (Detroit: Wayne State University Press, 2010).

Hildebrand, Robert C. Power and the People: Executive Management of Public Opinion in Foreign Affairs, 1897-1921 (Chapel Hill NC: University of North Carolina Press, 1981).

public" focuses on three 1911 Italian action-epics, Dante's Inferno (L'Inferno), The Crusaders (Gerusalemme liberata), and The Odyssey (L'Odissea). 
Hudson, Linda. The Mistress of Manifest Destiny: A Biography of Jane McManus Storm Cazneau, 1807-1878 (Austin: Texas State Historical Association, 2001).

Immerman, Richard H. Empire for Liberty: A History of American Imperialism from Benjamin Franklin to Paul Wolfowitz (Princeton: Princeton University Press, 2010).

Judis, John B. The Folly of Empire: What George W. Bush Could Learn from Theodore Roosevelt and Woodrow Wilson (New York: Lisa Drew/Scribner, 2004).

Kastor, Peter J. America's Struggle With Empire: A Documentary History (Washington DC: CQ Press, 2010).

Kelley, Robert. "Ideology and Political Culture from Jefferson to Nixon," The American Historical Review 82 (1977) 531-562.

Krall, Lisi. "Thomas Jefferson's Agrarian Vision and the Changing Nature of Property," Journal of Economic Issues 36 (2002) 131-150.

Mannix, Daniel P. Those About to Die: The Way of the Gladiator (New York: ibooks, 2001).

Marsden, Michael T. and Jack Nachbar, "The Modern Popular Western: Radio, Television, Film and Print," in Western Literary Association, A Literary History of the American West (Forth Worth TX: Texas Christian University Press, 1987) 1263-1282.

Merk, Frederick. "Dissent in the Mexican War," in Samuel Eliot Morrison, Frederick Merk, and Frank Freidel, eds., Dissent in Three American Wars (Cambridge: Harvard University Press, 1970) 33-63.

Merk. Manifest Destiny and Mission in American History: A Reinterpretation (New York: Alfred A. Knopf, 1963).

Mgbeoji, Ikechi. "The Civilised Self and the Barbaric Other: Imperial Delusions of Order and the Challenges of Human Security," Third World Quarterly 27 (2006) 855-869.

Moens, Alexander. The Foreign Policy of George W. Bush: Values, Strategy, and Loyalty (Aldershot UK: Ashgate, 2004).

Odom, William E. and Robert Dujarric, America's Inadvertent Empire (New Haven: Yale University Press, 2004).

Pfaff, William. The Irony of Manifest Destiny: The Tragedy of America's Foreign Policy (New York: Walker \& Company, 2010).

Pious, Richard M. The President, Congress, and the Constitution: Power and Legitimacy in American Politics (New York: The Press Press, 1984).

Porter, Bernard. Empire and Superempire: Britain, America and the World (New Haven: Yale University Press, 2006).

Raw, Laurence. The Ridley Scott Encyclopedia (Lanham MD: Scarecrow Press, 2009).

Rizzo, Sergio. "Why Less is Still Moore: Celebrity and the Reactive Politics of Fahrenheit 9/11," Film Quarterly 59 (2005-2006) 32-39.

Rose, Peter W. "The Politics of Gladiator," in Winkler, Gladiator: Film and History, 150-173.

Rowe, John Carlos. Literary Culture and U.S. Imperialism: From the Revolution to World War II (Oxford: Oxford University Press, 200o).

Saldin, Robert P. War, the American State, and Politics Since 1898 (New York: Cambridge University Press, 2010).

Schroeder, John H. Mr. Polk's War: American Opposition and Dissent, 1846-1848 (Madison: University of Wisconsin Press, 1973).

Silverstone, Scott A. Divided Union: The Politics of War in the Early American Republic (Ithaca NY: Cornell University Press, 2004).

Skrabec, Quentin R. William McKinley: Apostle of Protectionism (New York: Algora Pub., 2008).

Smith, Murray. "Film Spectatorship and the Institution of Fiction," The Journal of Aesthetics and Art Criticism 53 (1995) 113-127.

Solomon, Jon. "Gladiator from Screenplay to Screen," in Winkler, Gladiator: Film and History, $1-15$.

Stephanson, Anders. Manifest Destiny: American Expansionism and the Empire of Right (New York: Hill and Wang, 1995). 
"The 2000 Campaign: 2nd Presidential Debate Between Gov. Bush and Vice President Gore," The New York Times (October 12, 2000) A22.

Toplin, Robert Brent. Michael Moore's Fahrenheit 9/11: How One Film Divided a Nation (Lawrence KA: University of Kansas Press, 2006).

Wallace, Lew. Ben-Hur: A Tale of the Christ (New York: Harper \& Bros., 1880).

Wallace. The Fair God: Or, the Last of the 'Tzins - A Tale of the Conquest of Mexico (Boston: James R. Osgood and Company, 1873).

Weeks, William Earl. John Quincy Adams and American Global Empire (Lexington KY: The University of Kentucky Press, 1992).

Wetta, Frank J. and Martin A. Novelli, “'Now a Major Motion Picture': War Films and Hollywood's New Patriotism," The Journal of Military History 67 (2003) 861-882.

Winkler, Martin L., ed. Gladiator: Film and History (Malden MA: Blackwell, 2004).

\section{Websites}

http://www.imdb.com/title/ttoo52618/business

http://mediamatters.org/research/200406140007

http://business.highbeam.com/3554/article-1G1-21191193/spielberg-war

http://millercenter.org/scripps/archive/speeches/detail/3484

http://www.huffingtonpost.com/2009/o7/17/gallop-poll-iraq-war-a-mi_n_237875.html

http://www.mrpopculture.com/files/html/feb2o-1971 



\title{
MUSCLES AND MORALS: SPARTACUS, ANCIENT HERO OF MODERN TIMES
}

\author{
Thomas Späth and Margrit Tröhler
}

"Spartacus": for political historians the name calls to mind the Spartacus League, the German Revolution of 1918, and its leaders Rosa Luxemburg and Karl Liebknecht; dance enthusiasts will associate the name with Aram Khatchaturian and the music he arranged for his ballet Spartak; scholars of ancient history will be reminded of the writings of Plutarch and Appian and of the slave revolt that lasted from 73 to $71 \mathrm{BC}$; and connoisseurs of popular literature will recall the novels of Lewis Grassic Gibbon, Arthur Koestler, and Howard Fast. ${ }^{1}$ Today, however, "Spartacus" probably evokes neither political nor musical nor historical events or texts but an image. For this is the man with that determined look emanating from steely blue eyes, a face featuring a classical straight nose beneath which lies a square chin with a conspicuous dimple, and a body sporting muscular naked arms and thighs. For many, "Spartacus" is Kirk Douglas, the American actor starring in Stanley Kubrick's Spartacus (1960) in one of his best-known roles (see Figure 1).

When the image of the actor becomes superimposed on a historical figure, we encounter a problem that Jean-Louis Comolli aptly described more than thirty years ago as le corps en trop or "a body too many." 2 Using the example of Spartacus, our essay sets out to verify Comolli's hypothesis in films set in classical antiquity. We proceed from the construction of heroes in the theater and literature to the representation of muscular male bodies in the twentieth century. The bulging upper arms of the muscular heroes starring in the Spartacus films by Vidali (1913), Freda (1953), Kubrick (1960), Corbucci (1963), Dornhelm (2004), and DeKnight (2010) point toward the polysemy of popular culture. The latter uses and transforms

${ }^{1}$ Howard Fast, Spartacus (New York: n.p., 1951); Arthur Koestler, The Gladiators (trans. Edith Simon; London: J. Cape, 1939); Lewis Grassic Gibbon, Spartacus (London: Jarrold, 1933).

2 Jean-Louis Comolli, "La fiction historique: un corps en trop," Cahiers du cinéma 278 (1977) $5^{-16}$. Although the title of the English translation (see bibliography) is "A body too much," we use the grammatically correct "A body too many" as well. 


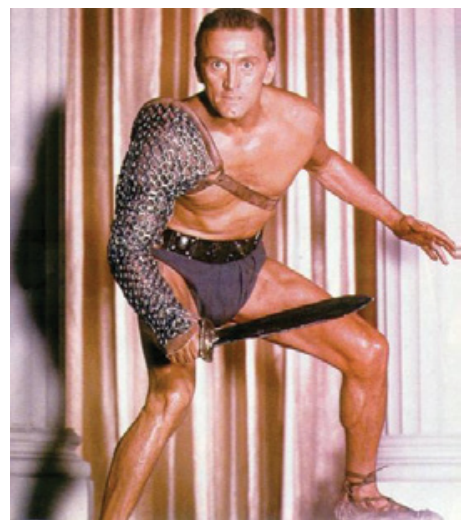

Figure 1 Kirk Douglas as Spartacus in Stanley Kubrick's Spartacus (studio photograph)

"the myth of antiquity" just as ancient cultures employed their myths as the stuff from which stories for the present were shaped.

\section{A Body Too Many? Initial Premise}

In 1977, Jean-Louis Comolli published an essay in which he claimed that characters in historical films always have "a body too many": the body of the actor, who avails himself of the character's imaginary and actualizes it as his own attribute, clashes with the culturally transmitted, albeit also changeable image, of the historical person, no matter how diffuse or eclectic this may be. In addition, following Ernst H. Kantorowicz, who distinguishes the "body natural" of the king from his "body politic", we can generally assume for historical persons a symbolic body as a persona ficta. ${ }^{3}$ Already during its lifetime, a body image is created for this symbolic body by all kinds of texts and iconographies. This image exists beyond the death of the natural body. Transmitted and transformed, it gives evidence of (in the sense of rendering visible) the immortal body politic of the persona ficta. The persona ficta in turn is rendered concrete in ever new texts and imagery up to the "living photography" of twentiethcentury cinema. A film, even by its title alone, may already evoke this persona by its name, which carries with it a political iconography and the

3 Ernst H. Kantorowicz, The King's Two Bodies. A Study in Mediaeval Political Theology (Princeton: Princeton University Press, 1957) 5 . 
popular knowledge imparted by novels and high-school history. Besides, this "body fiction," which mostly exists in exchanges between different media, is given historical reference. ${ }^{4}$ The only "real" body - whose "reality" in the cinema has nevertheless always been imaginary, since it is conveyed by the medium - is the actor's. Comolli argues that the actor's body doubles the historical body, and thereby competes with the body fiction. Thus, the characters appearing in historical films always leave room for ambiguity among the audience. Consequently, a "disbelief" in the fiction persists, since there is "a body too many" - the actor's. ${ }^{5}$

Extending Comolli's hypothesis, the actor's body can be said to represent an empty mask for the film character at best only at the beginning of the fiction. On the one hand, the actor brings along his own body image and quasi-physical presence, which he realizes through his acting (and which thus leads back to a casting decision). On the other, as soon as he is reasonably popular, the actor also carries his own sociocultural image (arising from previous roles and general information about his "person" as a celebrity) into the film; such a symbolic media body, as it were, further intensifies the actor's imaginary shadow boxing with the historical prototype. 6

However, various possibilities for dynamizing, and thus shaping, the historical figure also exist within cinematic representation. Comolli demonstrates how Pierre Renoir's performance in Jean Renoir's La Marseillaise (1938) renders fruitful the remoteness of Louis XVI's symbolic body, especially in how the actor exhibits the character's body and presents it as problematic, since the character cannot measure up to the symbolic role. Ultimately, the king's body - the body politic - becomes too much.

4 Following Kantorowicz, who speaks of the "mystic fiction" of the king's two bodies, Hans Belting introduces the term "body fiction"; Bild-Anthropologie: Entwürfe für eine Bildwissenschaft, (München: W. Fink, 2001) 97-98. However, he employs it more concretely than we do here, namely, as an image of the king in the shape of an effigy used in cultic contexts. On the popular knowledge arising from high-school history and which evokes historical subjects and figures, see Michèle Lagny, "Popular Taste: The Peplum," Richard Dyer and Ginette Vincendeau, eds., Popular European Cinema (London: Routledge, 1992). In his study of the marketing of epic films in general and Spartacus in particular, Martin M. Winkler, “'Culturally Significant and Not Just Simple Entertainment': History and the Marketing of Spartacus," in Winkler, ed., Spartacus. Film and History (Malden, MA; Blackwell, 2007) 198-232, esp. 210-222, provides interesting insights into the advertising materials addressed to high-school teachers.

5 Comolli, "La fiction historique: un corps en trop," 6.

6 On the many-layered construction of feature film characters, see Margrit Tröhler and Henry M. Taylor, "De quelques facettes du personnage humain dans le film de fiction," Iris 24 (1997) 33-57. 
Its abolition thus seems plausible in both diegetic and historical terms. Here, the actualization of the historical figure by the mise-en-scène and by the actor manages to realize the historical material, and to lend it new explosive force at the time of the Front populaire. ${ }^{7}$

Comolli's hypothesis holds true to a certain extent for all historical film characters. We argue, however, that films set in classical antiquity, and Spartacus in particular, present a somewhat different case. The popular imagination conceives antiquity largely as a fictional construct, the referential weight of which confers upon the theme and characters a touch of authenticity and continuous cultural tradition. Iconographically speaking, reasonably clearly drawn body fictions exist for only some very few "great" historical figures like Augustus, Nero, Julius Caesar, or Cleopatra. ${ }^{8}$ Their iconography has survived since antiquity, becoming absorbed and transformed over time by actualizations in historical painting, in stage plays whose plots are set in ancient history, and in the film performances by many different actors. What emerges here is the tension between the body fiction, in the above sense, and the "corps en trop," namely, when one of the body images becomes predominant, for instance Elizabeth Taylor's as Cleopatra or Peter Ustinov's as Nero.

For the majority of ancient figures, however, a new tension arises, because no ancient body fiction can be made out. Twentieth-century actors thus shadow box with a symbolic body that is a modern construction from the outset - albeit one that stakes a claim to ancient referentiality. Spartacus exemplifies this point, since he possesses no ancient symbolic body in terms of the above "body fiction." Nevertheless, we argue that a symbolic body of Spartacus did indeed exist - but, however paradoxical it may sound, this body image emerged as a modern hero's, which began its life only in the eighteenth century. ${ }^{9}$ Seen thus, Comolli's hypothesis needs to be fundamentally questioned, or rather expanded and reformulated. If we understand history as the appropriation of history by the "dialectical image," in Walter Benjamin's terms, that is, as an ever-changing construc-

\footnotetext{
7 Jean Renoir, Écrits 1926-1971 (Paris: P. Belfond, 1974) himself mentions that La Marseillaise was meant to be neither a historical nor a modern film, but quite simply a "timely" film.

8 Michèle Lagny, "Dans les pas d'Achille et d'Alexandre," in Tomas Lochman, Thomas Späth, and Adrian Stähli, eds., Antike im Kino: auf dem Weg zu einer Kulturgeschichte des Antikenfilms (Basel: Verlag der Skulpturhalle Basel, 2008) 202-209, comments on the missing "portrait" of Achilles.

9 See Lorna Hardwick, Reception Studies (Oxford: Published for the Classical Association, 2003) 5-11, for a discussion of the reception and its various modes of adaption, appropriation, refiguration, transposition, etc.
} 
tion that places one image of the past over another, ${ }^{10}$ then no "historical persons" with quasi-fixed "body fictions" tied to a past reality can exist.

For this reason, it is precisely the films set in classical antiquity that can help us understand that historical bodies emerge only from the manifold adaptations and transformations involved in reception: they allow us to trace how exchanges among different media continuously bring forth and alter body fictions. Thus, the body of Massimo Girotti in Freda's Spartaco (1953) is "en trop (too much)" in relation to the symbolic body of Mario Guaita in Vidali's Spartaco, il gladiatore della Tracia (1913); Kirk Douglas's sheer physicality in Kubrick's Spartacus (1960) in turn transforms Girotti's body fiction, and is itself then taken up and to a certain extent formed over again by Goran Visnjic's Spartacus in Dornhelm's television mini-series Spartacus (2004), and his by Andy Whitfield's in Spartacus: Blood and Sand (2010), and so on. ${ }^{11}$ We will begin testing our hypothesis by examining the "dramaturgical constants" or "transversal" meanings that pervade the various constructions of the body fiction, and then we will consider the range of meanings of Spartacus' body fiction in cinema since the 1910 .

\section{Spartacus Before the Twentieth Century}

No hero by the name of "Spartacus" existed in antiquity. While his name occurs in extant texts from Sallust to Appian, Plutarch, and Florus, ${ }^{12}$ Spartacus is not assigned heroic status in a modern sense, that is, as an

10 Walter Benjamin, "Über den Begriff der Geschichte," in Siegfried Unseld, ed., Illuminationen. Ausgewählte Schriften (Frankfurt am Main: Suhrkamp, 1977) 251-263. See also Detlev Schöttker, "Benjamins Bilderwelten. Objekte, Theorien, Wirkungen," in idem (ed.), Schrift, Bilder, Denken. Walter Benjamin und die Künste (Frankfurt am Main: Suhrkamp, 2004) 10-31, esp. 25-26.

${ }_{11}$ We also understand Spartacus as a myth in this sense, just as the image of Rome in films set in classical antiquity in general. Our approach here follows Peter Bondanella, The Eternal City: Roman Images in the Modern World (Chapel Hill: University of North Carolina Press, 1987) 1, who speaks of the "myth of Rome." He notes that the "myth is not so much a relic to be venerated as it is a flexible and limitless source for self-expression, a common heritage which has met the needs of successive generations, influenced the styles of different periods, and inspired widely different forms of artistic expression."

12 Appian, Civil War, 1.14 (116-120); Plutarch, Crassus, 8-11, Comparatio Nicias-Crassus 3.2, Pompeius 21.1-4, Cato minor 8.1-2; Florus, Epitome de Tito Livio, 2.8; Sallust, Hist. 3 fr. 90-94, 96-102, 106; Hist. 4 fr. 22-23, 25, 30-33, 37, 40-41. On these passages and other, less detailed ones, see Brent D. Shaw, Spartacus and the Slave Wars. A Brief History with Documents (Boston, MA: Bedford/St. Martin's, 2001) 130-165. On the literary sources, see also "Appendix I" in Keith Bradley, Slavery and Rebellion in the Roman World, 140 B.C.-7o B.C. (Bloomington: Indiana University Press, 1989) 133-139. The "Principal Ancient Sources on Spartacus" are also available in an English translation in Winkler, Spartacus, 233-247. 
exemplary figure. In Roman culture heroes are exemplary "great men" who embody the prevailing social norms. These norms can be fulfilled only by members of the Roman aristocracy, from whose actions the exempla were composed, that is, those small stories that function as the cogwheels and transmission belts of social memory, which in turn determine and convey the dominant norms. ${ }^{13}$ Given their social and legal status, slaves could thus be neither "great men" nor, by further extension, heroes. Even as wartime enemies, slaves were not considered equals: a Roman general who defeated unworthy enemies like slaves could not, as was customary, celebrate his victory as a triumph, but at most reckon with the less significant ovatio. ${ }^{14}$ Most surviving texts documenting the so-called "slave war"15 waged under Spartacus do not consider this war honorable, nor do they describe him as an enemy commander. The slave war, morever, is merely one episode in a series of external and internal threats during a century of civil wars extending from ca. 130 to 30 BC. ${ }^{16}$ Only Plutarch's biography of Crassus, who was given command against Spartacus, establishes the slave leader as one of the Roman general's adversaries. Plutarch thus renders tangible a few anecdotes shaping an ancient image of Spartacus around 170 years after the events. However, this by no means establishes Spartacus as an ancient hero. ${ }^{17}$

13 For a more detailed discussion, see Thomas Späth, "Faits de mots et d'images. Les grands hommes de la Rome ancienne," Traverse 5 (1998) 35-56, and Marianne Coudry and Thomas Späth, L'invention des grands hommes de la Rome antique. Die Konstruktion der grossen Männer Altroms. Actes du colloque du Collegium Beatus Rhenanus (Paris: Collections de l'Université Marc Bloch - Études d'archéologie et d'histoire ancienne, 2001), including numerous references to discussions on the problem of the "great men."

14 See Aulus Gellius 5.6.20-21.

15 The slaves seem to have considered their revolt less a "war" than a struggle for freedom; for a discussion of the aims of the revolt, see Bradley, Slavery and Rebellion in the Roman World, 98-125. For a description and characterization of Spartacus in terms of historical events, see the concise comparative survey of ancient texts in Alison Futrell, "Seeing Red. Spartacus as Domestic Economist," in Sandra R. Joshel, Margaret Malamud, and Donald T. McGuire, Jr., eds., Imperial Projections: Ancient Rome in Modern Popular Culture (Baltimore: The Johns Hopkins University Press, 2001) 80-81.

16 The series of belligerent events includes, among others, the war against Jugurtha in Numidia from 112 to 105; the invasions of Germanic peoples (Cimbri, Teutons) in northern Italy from 113 to 101, and the related ascent to power of Marius; the so-called Social War from 91 to 88; the war against Mithradates from 87 to 83 , and again from 74 to 64 ; Sulla's march on Rom in 88 and 83/82, and his subsequent dictatorship from 82 to 79 ; the revolt of Sertorius in Spain from 79 to 71 ; the campaigns against the sea pirates from 74 to 71 under the leadership of M. Antonius and in 67 under Pompeius; and the so-called Catilinarian Conspiracy in 63. The slave revolt under Spartacus occurred between these events from 73 to 71; both Crassus and Pompeius sought to take credit for its suppression.

17 See Plutarch (Crassus 8.3) for positive epithets on Spartacus. Nevertheless, positive appraisals fail to constitute a hero in themselves: Sallust (Hist. 3. fr. 91) also characterizes 
From the fifth century, Spartacus as a real historical figure passes unnoticed as a historical actor for about thirteen centuries ${ }^{18}$ - his name is mentioned at best in passing in histories of Rome. Only from the mid-eighteenth century does a heroic Spartacus begin to emerge. The number of pages allotted to us cannot accommodate a full chronological survey of how Spartacus was constructed as a hero from the eighteenth to the twentieth centuries, so we will simply summarize our findings here: in the Enlightenment, Spartacus became a heroic fighter for the general human right to individual freedom; in the nineteenth century, Spartacus as slave leader became a champion of national self-determination for ethnically-linguistically constituted peoples; and in the twentieth century he became a socialist hero of the struggle for liberation of the oppressed against their oppressors. ${ }^{19}$

\section{A Hero for the Cinema Audience: Spartacus's Career in the 196os}

Massimo Girotti's actualization of the "body fiction of Spartacus" established an exciting relationship between Riccardo Freda's Spartaco (1953) and the range of meanings supplied by literature, the theater, and earlier films set in classical antiquity in general, and particularly by Giovanni Enrico Vidali's Spartaco (1913). What emerged here was a historical body, the image of a heroic slave of Greco-Roman antiquity, a muscle-bound figure who fights against oppression. The image models Freda's Spartaco, to which Stanley Kubrick's Spartacus would subsequently refer.

Howard Fast's novel provided both the basis and the starting point for what is probably the best known film about Spartacus. ${ }^{20}$ He presented a blatantly obvious contrast between the morally reprehensible Romans and the exemplary slaves as antagonist classes. Alison Futrell has offered a convincing analysis of how the novel opposes slaves and Romans in terms of "life" versus "death," collective group consciousness versus an individual and hedonistic craving for power, country versus city, and good

Spartacus as ingens ipse virium atque animi ("of excellent power and spirit"), without him subsequently occupying more than an episodic function in historiography. The descriptions in Appian and Florus are similar in this respect.

18 The last known reference to our best knowledge occurs in Orosius 5.24.1-8, 18-19. See Shaw, Spartacus and the Slave Wars, 19.

19 For this, see Thomas Späth and Margrit Tröhler, "Spartacus - Männermuskeln, Heldenbilder oder: die Befreiung der Moral," in Lochman, Späth, and Stähli, Antike im Kino, 170-193.

20 On Fast, a bestselling author since the 1930s and a member of the Communist Party of the United States from 1943 to 1957, see Futrell, "Seeing Red. Spartacus as Domestic Economist," 90-91. 
heterosexual-monogamous patriarchal order versus bisexual-depraved indiscipline. ${ }^{21}$ Fast's comments on the genesis of the novel in his autobiography are revealing in terms of explaining this popular-communist viewpoint: while imprisoned, he had busied himself with German history during the interwar period, first intending to write a book about Rosa Luxemburg and her leading role in the Spartacus League, but eventually turning to the Spartacus material. ${ }^{22}$

Kirk Douglas was enthusiastic about Fast's novel. One of America's most successful actors at the time, Douglas had acted in a number of historical films, most recently as Odysseus in Ulysses (1954). ${ }^{23}$ Douglas was born to a family of Russian Jewish immigrants in a suburb of New York. Writing in his autobiography, he describes his reaction to reading Fast's Spartacus as follows: ${ }^{24}$

Spartacus was a real man, but if you look him up in history books, you find only a short paragraph about him. Rome was ashamed; this man had almost destroyed them. They wanted to bury him. I was intrigued with the story of Spartacus the slave, dreaming the death of slavery, driving into the armor of Rome the wedge that would eventually destroy her. I'm always astounded by the impact, the extent of the Roman Empire. Caesarea, Israel - full of Roman ruins.... Looking at these ruins, and at the Sphinx and the pyramids

21 Ibid., 90-97.

22 Howard Fast, Being Red (Boston: Houghton Mifflin, 1990), quoted in ibid., 91. Fast refers to C. Osborne Ward, The Ancient Lowly: A History of the Ancient Working People from the Earlies Known Period to the Adoption of Christianity by Constantine (Chicago: C.H. Kerr, 1907) as an essential source of information - which had been given to him by Communist officials for the purposes of ideological training. While Fast had not read Rafaello Giovagnoli's popular historical novel Spartaco (1874), he might have known the novels of L.G. Gibbon (pseudonym for J. Leslie Mitchell) and Arthur Koestler, published in 1933 and 1939 respectively. Gibbon presents a clearly socio-critical, romanticizing version of Spartacus, while Koestler, the "renegade" of Communism, describes the slave revolt as an example of a revolution that, like all revolutions, is doomed to failure. Just as Koestler, (The Gladiators, 316-319), observes in his "Postscript to the Danube Edition of 'The Gladiators,'” he began writing his novel at the time of the Stalinist purges around 1935, when he was still a member of the party, but already experiencing "progressive disillusionment with the Communist Party"; for him the novel became a "story of another revolution that had gone wrong": "Spartacus was a victim of the 'law of detours,' which compels the leader on the road to Utopia to be 'ruthless for the sake of pity." " Koestler understood The Gladiators as the counterpart to his novel Darkness at Noon (1941), the story of the Bolshevik commissar Rubashov, who pursued this "law of detours" to its bitter end, only to realise that his ideas had failed: "Thus the two novels complement each other - both roads end in a tragic cul-de-sac."

23 After the Italian Ulisse, he starred in Vincente Minelli's Lust for Life (1956) and Richard Fleischer's The Vikings (1958).

24 Kirk Douglas, The Ragman's Son: An Autobiography (New York: Simon and Schuster, 1988) 303-305. 
in Egypt, at the palaces in India, I wince. I see thousands and thousands of slaves carrying rocks, beaten, starved, crushed, dying. I identify with them. As it says in the Torah: 'Slaves were we unto Egypt.' I come from a race of slaves. That would have been my family, me.

This "humanist" enthusiasm, set against a religious Jewish background, attests to quite a different reading of Fast's novel than one colored by communism or the class struggle - and this might have been related to the fact that Douglas, whose own production company, Bryna Productions, took charge of making arrangements for the film, commissioned Dalton Trumbo rather than Fast to write the script. In doing so, Douglas nevertheless took a clear political decision: both Fast and Trumbo were among those blacklisted during the 1950s and hence banned from practicing their professions during the anticommunist persecutions raging at the time. After a decade of McCarthyism, Spartacus was the first film to defy the ban of persecuted authors and to mention their names officially in the credits. ${ }^{25}$

Trumbo in his script seems to have softened somewhat the differentiation between the Romans and slaves but nevertheless gives considerable weight to the military victories carried off by the slave army. Stanley Kubrick, however, did not appear to share this view. ${ }^{26}$ On the one hand, some of Kubrick's statements reveal his endeavor to convey historical authenticity or perhaps more precisely to visualize a foreign world. ${ }^{27} \mathrm{On}$ the other, he was less interested in idealizing the slaves as a harmonious collective than in depicting the tensions among the characters, which accounts for his intention to integrate elements from Koestler's The

25 See Futrell, "Seeing Red. Spartacus as Domestic Economist," 97-99; Maria Wyke, Projecting the Past: Ancient Rome, Cinema, and History (New York: Routledge, 1997) 60-63; Natalie Zemon Davis, Slaves on Screen. Film and Historical Vision (Cambridge, MA: Harvard University Press, 2000) 21-22; Theresa Urbainczyk, Spartacus (London: Bristol Classical Press, 2004) 119-125. One side-effect of this employment ban was the savings effect for production companies: blacklisted scriptwriters were still hired (albeit under ever different pseudonyms), but according to Urbainczyk (122) - unfortunately, her claim cannot be verified, since just as in other cases she provides no references - they received only a fraction of the previous fees. Urbainczyk points out that Trumbo could command up to $\$ 75$,0oo before he was blacklisted, and was thereafter offered $\$ 3,750$. Bryna productions explained the fact that the company employed five blacklisted authors in 1959 by referring to its endeavor to keep costs low.

26 Douglas, who had played one of the lead roles in Kubrick's anti-war film Paths of Glory, dismissed Anthony Mann, who had been appointed by co-producer Universal International Pictures, after a few days of shooting. See Marcus Junkelmann, Hollywoods Traum von Rom. "Gladiator" und die Tradition des Monumentalfilms (Mainz: P. von Zabern, 2004) 392 , fn. 467 .

27 Davis, Slaves on Screen, 24-25. 
Gladiators. ${ }^{28}$ Such widely differing views of the hero led to heated debates during the film's production, among others over the absence of victories by the slave army, the depiction of brutal or somewhat fairly aestheticized battle scenes, the all-too Christological demise of Spartacus on the cross, and the restriction of hope for liberation to one son. ${ }^{29}$ The result was a work with which nobody apart from Kirk Douglas as its producer and leading actor was truly satisfied; it nevertheless became the greatest box office success of $1960 .{ }^{30}$ Perhaps this success was indebted precisely to the broad spectrum of meanings and emotions into which entered the various strands of Spartacus' body fiction: a modern, popular hero carrying ancient references. The body of Kirk Douglas, the "steely-eyed and virile star,"31 superimposed itself on a symbolic body created over the past two hundred and fifty years. Consequently, Douglas' body became part of the evolving body fiction and a model for future transformations (see Figure 2).

The films made from the 1950s through the mid-196os reveal the sociocultural dimension of Spartacus as a heroic figure. Notwithstanding their dramaturgical concessions to the narrative conventions of the cinema as an institution, ${ }^{32}$ Freda's and Kubrick's films, released in 1953 and 1960

28 Duncan L. Cooper, "Dalton Trumbo vs Stanley Kubrick: The Historical Meaning of Spartacus," in Winkler, Spartacus, 58-6o.

29 For a detailed discussion, see Ibid. and Duncan L. Cooper, "Who Killed the Legend of Spartacus? Production, Censorship, and Reconstruction of Stanley Kubrick's Epic Film," in Winkler, Spartacus, 14-55. Both accounts read like a written defense of Dalton Trumbo and at the same time constitute a plea for the restauration of the film with material partly shot later, but which was subsequently not included in the final version. Cooper had already published earlier versions of these texts, which trace the conflicts in detail, namely, in Cinéaste and an electronic version in 1996 at http://www.visual-memory.co.uk/amk/doc/ cooperdex.html (accessed on February 16, 2012). Junkelmann, Hollywoods Traum von Rom, 151-158, also assembles anecdotal material on the differences of opinion between director, scriptwriter, novelist, and actors; on the other hand, however, his description reveals a lack of understanding for the historical film as a genre and of the cinema as an institution; see, for instance, his comment $\left({ }_{156}\right)$ that "like in so many historical films, the grafted love story has a highly detrimental effect."

30 Martin M. Winkler, "The Holy Cause of Freedom: American Ideals in Spartacus," in Winkler, Spartacus, 168, explains the failure of the conservative propaganda against the film by the fact that it was ultimately "a mainstream American work," which presents an "all-American Spartacus." Winkler also attempts to describe in some "key scenes" how the film corresponds to the American zeitgeist and the prevailing discourses in the early 1960 .

31 Thus begins the minibiography of Kirk Douglas available online at http://imdb.com/ name/nmooooo18/ (accessed on February 16, 2012).

32 See, for instance, Robert A. Rosenstone, "History in Images/History in Words: Reflections on the Possiblity of Really Putting History Into Film," American Historical Review 93 (1988) 1173-1185; see also Philip Rosen, Change Mummified. Cinema, Historicity, Theory 


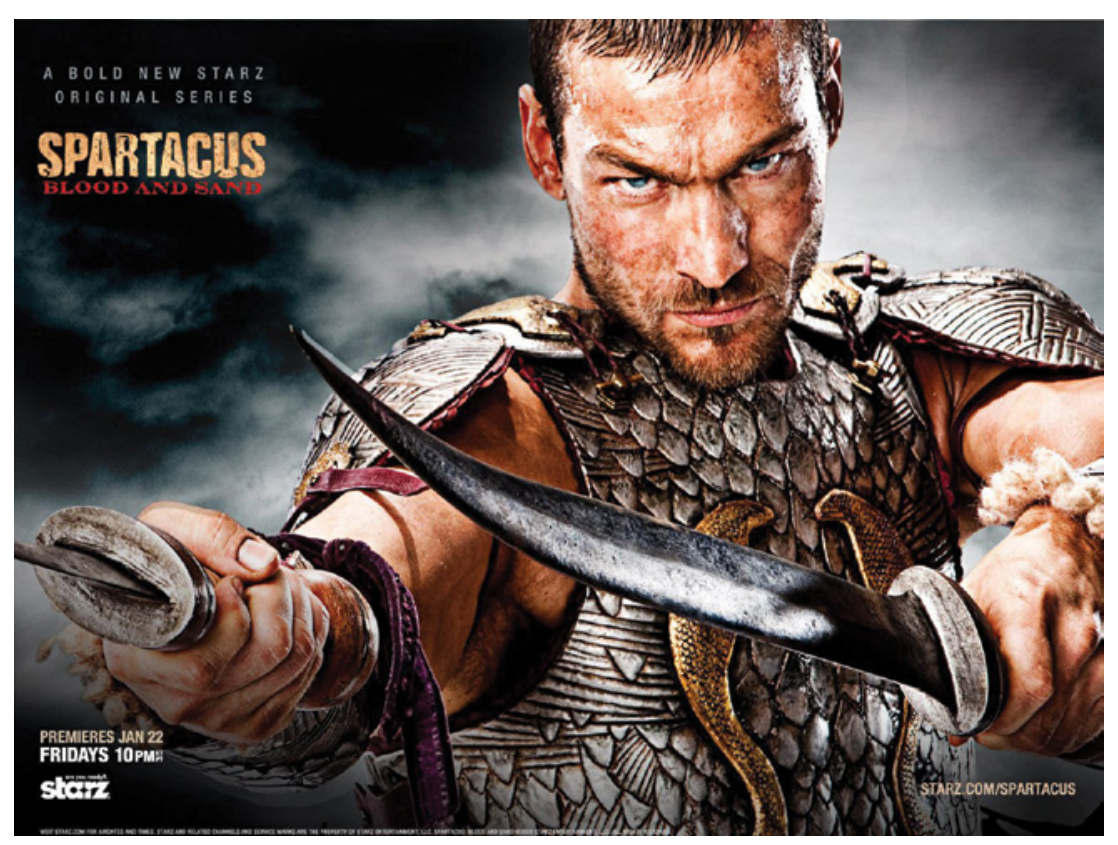

Figure 2 Andy Whitfield as Spartacus in the TV-Series Blood and Sand by Steven S. DeKnight (2010)

respectively, can be said to have at least laid claim to historical reference, thereby placing themselves within the tradition of the image of Spartacus that had evolved since the eighteenth century. Besides these two cinematic versions, at least three other Italian productions were made during this period, each treating the leader of the slave rebellion in a fictionalizing, fantastic manner: Il figlio di Spartaco (1963), directed by Sergio Corbucci; Spartaco e i dieci gladiatori (1964; a.k.a. Gli invincibili dieci Gladiatori), directed by Nick Nostro; and La vendetta di Spartacus (1965), directed by Michele Lupo. ${ }^{33}$

(Minneapolis: University of Minnesota Press, 2001) 147-199, esp. 178-180; Davis, Slaves on Screen, $1-15$.

${ }^{33}$ The renaissance of films set in classical antiquity since Gladiator (2000) has recently led to the aforementioned television series directed by Robert Dornhelm (Spartacus, 2004) and by Steven S. DeKnight (Spartacus: Blood and Sand, 2010), and furthermore to two so-called documentaries on Spartacus (The Real Spartacus, Bill Lyons, 2001); Espartaco Informe confidential, Jorge Ortiz de Landázuri Yzarduy, 2003), and one short (Spartacus, Virginie Lovisone, 2003); in the wake of this development, a new DVD edition of Il colosso di Roma/Muzio scevola (Giorgio Ferroni, 1964) was launched without further ado under the German title Spartacus - Der Held mit der eisernen Faust, although the film's protagonist is Gaius Mucius Scaevola ("the left-hander"), the legendary Roman hero (see Livy 2.12.1-13.5). 
Corbucci's film invents the continuation of the "story" in the adventures of Spartacus' son. Unaware of his true identity, Randus is taken prisoner by slave traders while serving as one of Caesar's (Roman) officers in Egypt. When he finds out about his true origin, he declares that "If Rome is for slavery, then I'm against Rome." Henceforth, he resumes the struggle against slavery. Eventually, however, he reestablishes Caesar's good rule, which protects the people against the barbaric tribal leaders, the "Saracens," as much as against the corrupt Roman governors. Or as Richard Dyer has aptly observed: "[He] restores enlightened colonialism." ${ }^{4}$ Randus, Spartacus' son, is played by bodybuilder Steve Reeves, who portrays him as a very southern type in an exotic, oriental setting, whose cinematic desert iconography, like its representation of violence in the fighting scenes, already seems to anticipate the Italian Western. ${ }^{35}$ The two other films inherit from the figure of Spartacus the idea of the slave revolt. However, this serves only to initiate the staging of a sequence of loosely connected wrestling and battle scenes as well as feasts, the excess of which also parodies the genre of films set in classical antiquity. This development places the figure of Spartacus within a series of mythified fantasy figures, of musclemen like Ursus, Hercules, Samson, or Maciste: ${ }^{36}$ the popular hero as it were returns to vaudeville theater, where the physical and cinematographic spectacle attracts greater attention than the level of values and emotions inherited from the bourgeois theater of the Enlightenment (Bernard-Joseph Saurin's tragedy, Spartacus, 1760) and from the nationalist and socio-critical novel (Giovagnoli, Fast).

34 Richard Dyer, White (London: Routledge, 1997) 176.

35 See also Il Figlio di Cleopatra (1962), directed by Ferdinando Baldi, where the physical appearance and body display of the bodybuilder Mark Damon, who appears in the role of El Kabir, is made to resemble that of a bedouin, and is thus even more strongly "orientalized" and erotized. On the orientalization of white musclemen, see Dyer, ibid., 177; for a discussion of the eroticizing and feminizing of male and female figures as an Oriental Other, see Ella Shohat, "Gender and Culture of Empire: Toward a Feminist Ethnography of the Cinema," in Hamid Naficy, Teshome H. Gabriel, eds., Otherness and the Media. The Ethnography of the Imagined and the Imaged (Langhorne, PA: Harwood Academic Publishers, 1993) $45^{-84}$.

36 See Vittorio Martinelli's extensive "filmography" of Italian productions in the period from 1913 to 1926 in Monica dall'Asta, Un cinéma musclé: le surhomme dans le cinéma muet italien (1913-1926) (Crisnée: Yellow Now, 1992) 215-253. See also Monica dall'Asta, "Maciste - ein Stereotyp westlicher Männlichkeit," KINtop 7 (1998) 84-97. Annie Collognat, "L'antiquité au cinéma," Bull. Ass. G. Budé (1994-95) 334-336, claims that fifteen Maciste films were produced between 1915 and 1920, and she refers to six Maciste productions between 1961 and 1963 . 
The figure of Spartacus, bearing nothing more of classical antiquity than his name, is very well-suited to delineate the complexity of the peplum heroes of the 1950s through mid-196os, and their ability to be modulated, and to recognize them as a historical and fictional conglomerate that somehow remained valid both before and after this period. Indeed, Spartacus proves to be a highly alterable body hero, a vehicle onto which the historical and the contemporary can load ever new associations. The figure can lift and carry the political, social, moral, economic, and even cinematographic concerns into the different instances of actualization, where they come to rest, accumulate, and amalgamate (in Paul Ricoeur's sense of the transhistorical self-structuring "sedimentation" of tradition, or as a "collage of commonplaces" in Gramscian terms). ${ }^{37}$ Our current cinephile memory is certainly dominated by the image of Kirk Douglas as Spartacus. ${ }^{38}$ We can nevertheless assume that at least the Spartacus films made between 1953 and 1965 respond to one another, and that they plausibly blend into a multifaceted image in contemporary reception (which lasted well into the 1970s through their international release on television and in rural cinemas). ${ }^{39}$ Even if the figure of Spartacus might not necessarily stand out from the mass of sword and sandal films of that time for the average spectator, we argue that it nevertheless serves analysis as an example. Spartacus can be considered a popular hero insofar as Freda's and especially Kubrick's films were commercial successes as well as political and media events.

37 See Paul Ricoeur, Temps et récit (Paris: Seuil, 1984) II, 30-31, on the notion of the cumulative tradition, whose process-like nature we transfer here onto historical figures in films set in classical antiquity as a configuration of cultural memory. In describing the conception of history in biopics, Marcia Landy draws on Gramsci's notion of folklore as a palimpsest; see Marcia Landy, Cinematic Uses of the Past (Minneapolis: University of Minnesota Press, 1996) 151-161. Both concepts are similar to the aforementioned idea of the appropriation of history in the "dialectical image," as conceived by Benjamin, "Über den Begriff der Geschichte," who also understood this as a mnemonic image.

38 See here the comments collected at http://imdb.com/title/tto361240/usercomments (accessed on February 16, 2012) regarding the reedition of Dornhelm's "myth" of Spartacus in 2004; most commentators mostly compare Goran Visnjic and the film with the 1960 original.

39 On the current intertextuality of films set in classical antiquity, see Michèle Lagny, "Dans les pas d'Achille et d'Alexandre," in Lochman, Späth, and Stähli, Antike im Kino, 202-209. Winkler's assertion in his "Introduction" (Winkler, Spartacus, 8), namely, that Kubrick's Spartacus "has eclipsed all other Spartacus films made before or after," is thus certainly too simple. 


\section{Body Fictions of Masculinity}

Three interlocking levels enter into the imaginary body fiction of the cinematic Spartacus. These three levels actualize with different weight in the various cinematic versions the triform heroic figure mentioned above, and thus often are contradictory in themselves. While these aspects need not necessarily belong to the body fiction of a historical figure, films set in classical antiquity include the staging of the muscular body. The following levels can thus be distinguished: archaic masculinity, the conglomerate of values of the domesticated superhero, and the body as a media spectacle.

\section{Archaic Masculinity}

Archaic masculinity refers back to the strongmen appearing at fairgrounds, in vaudeville theater, and in early cinema. It has stood behind the figure of Spartacus at least since Edwin Forrest's initial 1831 performance in Robert Bird's The Gladiator..$^{40}$ Such masculinity is about the demonstration of physical strength: ${ }^{41}$ the fighting men are presented more or less as human beings possessing above-average strength and courage. Gladiators and slaves are thereby repeatedly associated with animal elements: they fight against animals or like animals, or they are treated like animals, wear animal skins, or are only scantily clad. ${ }^{42}$ For the Romans, they have not yet

40 Robert Montgomery Bird, "The Gladiator," in Jeffrey H. Richards, ed., Early American Drama (New York: Pengin Books, 1997).

41 Charles-Antoine Courcoux, "From Here to Antiquity: Mythical Settings and Modern Sufferings in Contemporary Hollywood's Historical Epics," Film \& History 39 (2009) 29-38, shows the connection between masculinity and nature in recent Hollywood productions set in antiquity. On the staging of archaic masculinity in early cinema, which stems from nineteenth-century fairground traditions, see dall'Asta, Un cinéma musclé. Irmbert Schenk, "Von Cabiria zu Mussolini. Zur Geburt des monumentalen Historienfilms in Italien," in Malte Hagener, Johann N. Schmidt, and Michael Wedel, ed., Die Spur durch den Spiegel. Der Film in der Kultur der Moderne (Berlin: Bertz, 2004) 180, also mentions a connection between early films set in classical antiquity and opera; he also discusses (182) the interrelation between the birth of the monumental historical film in Italy and the fascist "fantasies of collective greatness." On the fascist iconography of musclemen, see also, Dyer, White, $169-174$.

42 Not only the slaves but also the enemy soldiers - the gangs under Crassus' command appearing in Corbucci's Il Figlio di Spartaco wear leopard skins, similarly to Baldi's Il Figlio di Cleopatra. Other films portray the Germanic peoples (barbarians) as feral humans or half animals, such as Sergio Grieco's Antea, la schiava di Roma (1960). Wearing animal skins is a sign of the barbaric in films set in classical antiquity; Natacha Aubert, "Roger Moore en Romulus: Tite-Live lu par Cinecittà (L'Enlèvement des Sabines, Richard Pottier, 1961)," in Lochman, Späth, and Stähli, Antike im Kino, 194-201, has shown that the early Romans were also presented thus in Richard Pottier's The Rape of the Sabines (1960). 
entered civilization, as reflected in their darker complexion, which marks them as culturally other and socially inferior. ${ }^{43}$ Where the cinema endows slaves with the power of conviction to rise against (Roman) oppression and decadence, they represent what Joseph Campbell called the "primordial hero." Such a hero accomplishes or will accomplish the superhuman, and will thus "create a world," 44 as if making a cinematic promise to history to abolish slavery, or present-day injustice and poverty. While slave revolts usually begin impulsively, spontaneously, and chaotically, ${ }^{45}$ within the cinematic production code such action legitimates and ennobles the use and representation of violence, and thus archaic masculinity, in the service of humanity and "natural law." At the same time, however, the rebellious slaves must also learn to control their physical strength and passions and to gain access to language (that is, the symbolic): Kubrick's Spartacus in particular explicitly foregrounds this theme by having Spartacus exemplify this development. ${ }^{46}$

43 Dyer, White, 161-162. Besides the ethnic and social aspects of class, the gradation of complexions by gender also becomes fundamental: male characters tend to have darker skin than female ones (or are shot in corresponding light), as in the aforementioned Spartacus films. Tomas Lochmann has drawn our attention to the fact that comparable markings also occur in the iconography of Attic vase painting.

44 Joseph Cambell, The Hero With a Thousand Faces (Novato, CA: New World Library, 2008) 271-278.

45 Precisely this aspect singles out Kubrick's Spartacus for the ideologically underpinned criticism leveled at the film in the East German program text (Heinz Hofmann, "Spartacus," Progress Film Programm 50, 1966 [four-page foldout]): "As a master swordsman, Spartacus had organized a plot in the gladiator school at Capua and was able to escape with his supporters. But the film distorts this into a spontaneous act.... Different versions concerning the goal of the uprising, conditioned by social groupings which harbored self-serving plans, led to several splits among the slave army, which became weaker and weaker. Even these essential historical facts of the case are suppressed in the film, whereas Rome concentrated all its power on its defeat."

46 Ina Rae Hark, "Animals or Romans. Looking at Masculinity in Spartacus," in Hark and Steven Cohan, eds., Screening the Male. Exploring Masculinities in Hollywood Cinema (London: Routledge, 1993) 151-172, illustrates the development from the animal to the human and to language in Kubrick's Spartacus. The Christological association, present in both Kubrick and Freda, also extends this connection to the biblical film set in classical antiquity. As Ashton D. Trice and Samuel A. Holland, in Heroes, Antiheroes and Dolts: Portrayals of Masculinity in American Popular Films, 1921-1999 (Jefferson, NC: McFarland, 2001) 97, emphasize, this stages the development of the hero from heathen to Christian, from "sinner" to "saint." Such changes, especially with regard to the protagonist, can be interpreted as a basic "civilizing" instance of purification and of the knowledge (of becoming human and undergoing acculturation), which also occurs in a different form in the bourgeois Bildungsroman. 


\section{The Domesticated Superhero}

This "becoming human" leads us to the second level, that of heroic values: where the "primordial hero" possesses at best a Manichaean morality, as Maciste already does in Giovanni Pastrone's Cabiria (1914), and which serves to save the weak, the idolized woman, and civilization (that is, humanity), ${ }^{47}$ in following the example of Spartacus the slaves acquire considered action, military and political tactics, class consciousness, solidarity and the passion of the heart for the beloved woman, as well as a sense of family. These aspects charge the genre of the war film with moral, ethic, ideological-political, melodramatic, and, in the case of the Bible film, also with explicitly Christian components. Spartacus, the superhero (who is "larger than life") unites all these aspects in himself, apart from the openly Christian one, as long as he remains bound to the axiological role pattern as in Freda, Kubrick, and Corbucci. However, he is not superhuman but instead has doubts, feels the burden of responsibility, is vulnerable to feelings, and is overwhelmed by the historical situation. ${ }^{48}$ Even if his death turns him into a martyr and preserves the historical-mythical image of the hero, his narrative representation (regardless of the version) turns him into a bourgeois-tragic hero: when actualized in the 1950s, the hero has internalized the conflict and must subject his whole life to the demands of his convictions. ${ }^{49}$

Spartacus thus approaches the vanquished and the broken anti-heroes of other contemporary genres, which stage the crises of masculinity, the self-made man, and social values. He thereby never becomes a truly individual, psychological character, nor does he ever allow himself to be entirely domesticated. Rather, the ideas for which he fights "transcend" him,,$^{50}$ even if - similarly to an anti-war film - his concrete moral and political ideals for humanity are (temporarily) lost. In the popular genre

47 dall'Asta, Un cinéma musclé, 41, refers to Umberto Eco, who establishes the figure of the Maciste and its narrative patterns as a new phenomenon of the nineteenth-century popular novel. She describes this "strongman" as an "incomplete subject" (45).

48 Francis Vanoye, Scénarios modèles, modèles de scenarios (Paris: Nathan, 1991) 53-54, thus describes the modern "problematic character."

49 See Peter Szondi, Die Theorie des bürgerlichen Trauerspiels im 18. Jahrhundert: der Kaufmann, der Hausvater und der Hofmeister (Frankfurt am Main: Suhrkamp, 1973) $84-85$.

50 As in Freda, where the hero's melodramatic inclination to passionate, impossible love for Sabina leads his values into disarray, it is realigned by his mission: when the screaming of a tortured slave reawakens his class consciousness after an amorous adventure with Sabina, he tears open his tunic before returning to his own kind and once again bares his chest (the "animal" moment seems well-suited to the tragic hero here). 
of the peplum, however, no coherent, unified discourse emerges beyond the general humanist message of peace, freedom, and justice. Within his specific character constellation, the ancient collective hero (as a body fiction), who fights for a better society and fails, can thus voice specific contemporary concerns. For example, Kubrick's Spartacus echoes those of the McCarthy era, the civil rights movement, feminism, and homosexuality, while he also conveys the bourgeois, middle class values of the nuclear family, muscular manhood, cool restraint, and intelligence. Through its contradictoriness and "openness," such a cinematic work of popular culture can be appropriated by different sides, ${ }^{51}$ just as this seems to have contributed to making it (and to a certain extent also films set in classical antiquity in general) an outstanding success. ${ }^{52}$

\section{The Body as a Media Spectacle}

Physical performance and the staged representation of the body in the media turns the hero into a star especially on a third level. The studios endorsed the motto "Bigger is Better" to respond to the crisis of the cinema in the face of growing competition from television in the United States and to stimulate coproductions. ${ }^{53}$ Internationally distributed monumental films produced in Hollywood and Cinecittà, which was rebuilt after the war largely with the help of American money, demonstrate economic power, state-of-the-art technology, and are structured like media events, as Vivian Sobchack has observed. ${ }^{54}$ Not only actresses but also male bodies are touted for their beauty and erotic charisma. However, the

51 On the theory of popular culture as a many-layered and often contradictory range of available meanings, see, among others, Umberto Eco, "Die Struktur des schlechten Geschmacks," in Eco, Apokalyptiker und Integrierte. Zur kritischen Kritik der Massenkultur (Frankfurt am Main: S. Fischer, 1984) 59-115, and John Fiske, "Popular Culture," in Frank Lentricchia and Thomas McLaughlin, eds., Critical Terms for Literary Study (Chicago: University of Chicago Press, 1990) 321-335; on the problems of the notion of popular from the point of view of reception, see Pierre Sorlin, "Les deux périodes antiquisantes du cinéma italien," in Lochman, Späth, and Stähli, Antike im Kino, 88-97.

52 President John F. Kennedy also took a public stand against anti-communist and Catholic calls to boycott the film; see Wyke, Projecting the Past, 71, fn. 123 and 200, and Winkler, Spartacus, 188, fn. 60.

53 Trice and Holland, Heroes, Antiheroes and Dolts, 96.

54 Vivian C. Sobchack, "Surge and Spendor. A Phenomenology of the Hollywood Historical Epic," Representations 29 (1990) 24-49. On the monumental film as the eternal recurrence of the same, see Klaus Kreimeier, "Der mortifizierende Blick: Von der Wiederkehr des Immergleichen im Monumentalfilm," in Jürgen Felix, Bernd Kiefer, Susanne Marschall, and Marcus Stiglegger, eds., Die Wiederholung (Marburg: Schüren, 2001) 325-334. 
review of Vidali's Spartaco of 1913, published at the time in the Hungarian German-speaking newspaper Neues Pester Journal, reveals that such advertising is by no means a new phenomenon. It was already a feature of the cinema industry during the large-scale productions of the 1910s. The reviewer praises Maria Guaita's athletic body as the "epitome of human beauty!"; Guaita had won the male beauty prize awarded by the Académie des Beaux-Arts de Paris for his "classical features" and his "unsurpassable physique (according to the magazine Pesti Kirlap). ${ }^{55}$ Vidali's film was also praised for its crowd scenes and atmospheric set design. ${ }^{56}$ Writing about Fred Niblo's Ben Hur (1925) as a "lavish opera," Siegfried Kracauer also mentions in the same breath the cost of materials, the crowds, and the physical appearance of Ramon Novarro, who "is as beautiful as Valentino," and epitomizes "the American-Spanish-Mexican type." He thus underscores the internationality of the film. ${ }^{57}$

What is new in the 1950s is at best the fact that widescreen cinemas, technicolor processes, sophisticated technical effects, and larger budgets permitted even more magnificient stagings of the battle of materials. ${ }^{58}$ The cinema as spectacle and the spectacle of the oiled, gleaming, raw, muscular bodies of half-naked male protagonists, who were often played by bodybuilders, models, or sportsmen already in the limelight beyond the cinema, and whose monumental performances complemented or surpassed each other, also explicitly addressed the contemporary female audience. ${ }^{59}$ Obviously, male bodies are thereby commodified: they are often staged as erotic, exotic-oriental objects of desire mostly exaggerating the southern type to appeal to the female protagonists and audience. ${ }^{60}$ Their visible

55 Both articles are quoted by Martinelli in dall'Asta, Un cinéma musclé, 216.

56 See the contemporary critique by James McQuade in Moving Picture World (quoted in Davide Turconi, "I film storici italiani e la critica americana dal 1910 alla fine del muto," Bianco e Nero 24 (1963) 52-56.

57 Siegfried Kracauer, "Ben Hur," in Karsten Witte, ed., Kino: Essays, Studien, Glossen zum Film (Frankfurt am Main: Suhrkamp, 1974) 163-165.

58 Cabiria (1913) exhibits not only lavish material costs but also the (childlike) joy in destruction, in a "battle of materials," since the pompous decor of the villa situated at the foot of Mount Vesuvius has been leveled to the ground within ten minutes of the film's opening. The monumental films produced in the 1950s enhance this demonstration of materials and large dimensions, which Sobchack, "Surge and Spendor: 29, interprets as an expression of flourishing capitalism, in whose excess we participate as "embodied spectators" and "historical subjects." It is worth recalling that the Guiness Book of Records was also first published in 1955 .

59 Trice and Holland, Heroes, Antiheroes and Dolts, 99, mention the advertising for DeMille's Samson and Delilah (1949), which explicitly addressed the female audience; the film review published in New York Times touted the leading actor Victor Mature as a "hunk" (that is, 'an attractive and well-built man').

60 See Dyer, White, 147-155, and 167. 
and unfettered physicality and performance confers upon the artificiality of the monumental film a physical authenticity. At the same time, the archaic masculinity of the primordial hero is aestheticized by the mediabased and economic-technical demonstration of performance, and thus consoles us for the uncertainty of values or, in the case of those films only featuring wrestling scenes, for their absence. ${ }^{61}$ Reminiscent of the excess of Baroque churches and its overwhelming effects, going to the cinema becomes an event and experience that attempts to produce "the highest degree of immediate physical existence both on the screen and also for the audience." ${ }^{62}$ Such an event and experience enables the cinematic and physical spectacle to somehow reclaim the moral hero. ${ }^{63}$

\section{Setting Free Morality}

The following remarks are couched in general terms because the Spartacus films are no exception in this respect: whether auteur cinema or B-movie, they always stage the muscular male hero - more or less aesthetized, eroticized, and endowed with moral values - for the media and physical experience of the monumental. The body fiction of the spectacle and of the (capitalist) machinery of the cinema surpasses the historical figure by far. If history is an "intoxicant," as Peter von Matt has remarked with reference to historical narratives, ${ }^{64}$ then the films set in classical antiquity produced during the economic miracle of the 1950s and 1960s, in whose surge they allowed spectators to participate, reactualize the enchantment

61 If the female characters appearing in the various Spartacus films (Freda, Kubrick, Corbucci, Dornhelm) also join the male protagonists in their struggle for moral-humanist values, Spartacus "outdoes" their media performance (in combination with archaic masculinity); beyond the individual body, the choreography of these films emphasizes the staging of masculinity. Gender differences are thus affirmed on another level. Yet, following Heide Schlüpmann, "Die Geburt des Kinos aus dem Geist des Lachens," Frauen und Film 53 (1992) 87-94, it could be argued that the physical spectacle makes possible a new physical and sensual relationship between the sexes, even in parodistic wrestling films, which tend to be misogynistic.

62 Siegfried Kracauer, "Geschichte und Fantasie," in Theorie des Films: Die Errettung der äußeren Wirklichkeit (Frankfurt am Main: Suhrkamp, 1984) 119, with reference to Niblo's Ben Hur. His sense of realism coincides here with Vivian Sobchack's phenomenological approach.

63 The popular films set in classical antiquity produced in the 1950s and 1960s already anticipate the "new" superhero of action films made in the 1980s; see Trice and Samuel A. Holland, Heroes, Antiheroes and Dolts, 96-98, or Yvonne Tasker, Spectacular Bodies: Gender, Genre and the Action Cinema (London: Routledge, 1993).

64 See Von Matt in the introduction to Die tintenblauen Eidgenossen (2001), quoted in Sibylle Birrer, "Neues vom Alten. Historische Romane und ihre anhaltende Popularität," Neue Zürcher Zeitung 26 (2002) 59. 
of the world, ${ }^{65}$ which has always been inherent in the cinema. Functioning as intoxicants, such films combat the overlapping crises of the cinema, of morality, and of masculinity.

The "morality" of these films has at least two (paradoxical) meanings: an ousting of morality in favor of the monumental and excessively physical spectacle; and a setting free of moral, sometimes political, but especially generally humanistic categories, which offer a manifold parallel range of meanings that legitimates excess but also puts it in its place once again.

\section{The Body Fiction of Ancient Figures}

Returning to our initial hypothesis, we can now formulate three claims arising from our overview of the construction and permanent modification of Spartacus as a body fiction. First, Comolli's concept of the corps en trop must be reformulated for films set in classical antiquity, since the body fiction of ancient figures in general and that of Spartacus in particular can hardly be based on a popularly transmitted iconography, nor can historical knowledge produce a truly concrete notion that would interfere with the actor's embodiment of the figure. His name evokes the symbolic body as a malleable shell. The ancient figure possesses no continuous body image, which is instead created through the actualizations of classical antiquity since the Renaissance or, in the case of Spartacus, since the Enlightenment, even if constants can be discerned at times. Especially in the scenic and subsequent cinematic actualizations of the ancient figure by different actors, their mediated physicality becomes foregrounded; in certain cases, the image of the actress or actor dominates the body fiction for a certain time.

Second, this also means that antiquity exists largely in the popular imaginary as a fictional construct, which serves as a point of reference that confers upon the material and the historical figures a sense of authenticity. For these films, however, antiquity is myth, whether in Bondanella's terms or those of classical Greek tragedy. It is raw material, available for almost any shaping and adjustment.

Third, the historical-sensual body of ancient figures is created predominantly within a body of interrelated films. Early cinema, however, takes

65 As a countermove to the "disenchantment of the world" by science in modern society, as described by Max Weber, "Die Entzauberung der Welt," in Weber, Wissenschaft als Beruf (Stuttgart: Reclam, 1995) 44. 
up the popular iconography of nineteenth-century (muscular) bodies, and at the same time graces itself with the cultural, bourgeois value of ancient themes and, in the case of the story of Spartacus, with its variable appropriation and semantic flexibility since the Enlightenment. The emotional diversity of meanings carried by an ancient figure thus emerges over time, especially in the conversation among individual films. This process of accumulating figural aspects, and with them the conglomerate of facets that transform the symbolic body time and again, continues to elaborate the popular notion of ancient history. ${ }^{66}$

\section{Works Cited}

Aubert, Natacha. "Roger Moore en Romulus: Tite-Live lu par Cinecittà (L'Enlèvement des Sabines, Richard Pottier, 1961)," in Tomas Lochman, Thomas Späth, and Adrian Stähli, eds., Antike im Kino: aufdem Weg zu einer Kulturgeschichte des Antikenfilm (Basel: Verlag der Skulpturhalle Basel, 2008) 194-201.

Belting, Hans. Bild-Anthropologie. Entwürfe für eine Bildwissenschaft (Munich: W. Fink, 2001).

Benjamin, Walter. "Über den Begriff der Geschichte," in Siegfried Unseld, ed., Illuminationen. Ausgewählte Schriften (Frankfurt am Main: Suhrkamp, 1977) 251-263.

Bird, Robert Montgomery. "The Gladiator," in Jeffrey H. Richards (ed.), Early American Drama (New York: Pengin Books, 1997).

Birrer, Sibylle. "Neues vom Alten. Historische Romane und ihre anhaltende Popularität," Neue Zürcher Zeitung 26.2 (2002) 59.

Bondanella, Peter. The Eternal City: Roman Images in the Modern World (Chapel Hill and London: University of North Carolina Press, 1987).

Bradley, Keith. Slavery and Rebellion in the Roman World, 140 B.C.-7o B.C. (Bloomington: Indiana University Press, 1989).

Cambell, Joseph. The Hero With a Thousand Faces (Novato, CA: New World Library, 2008).

Collognat, Annie. "L'antiquité au cinéma," Bull. Ass. G. Budé (1994-95) 332-351.

Comolli, Jean-Louis. "La fiction historique: un corps en trop," Cahiers du cinéma 278 (1977) 5-16 [= "Historical Fiction: A Body too much," Screen 19 (1978) 41-53].

Cooper, Duncan L. "Who Killed the Legend of Spartacus? Production, Censorship, and Reconstruction of Stanley Kubrick's Epic Film,” in Martin Winkler, ed., Spartacus: Film and History (Malden, MA; Blackwell, 2007) 14-55.

—. "Dalton Trumbo vs Stanley Kubrick: The Historical Meaning of Spartacus," in Winkler, Spartacus: Film and History, 56-64.

Coudry Marianne, and Thomas Späth, eds., L'invention des grands hommes de la Rome antique. Die Konstruktion der grossen Männer Altroms. Actes du colloque du Collegium Beatus Rhenanus (Paris: Collections de l'Université Marc Bloch - Études d'archéologie et d'histoire ancienne, 2001).

Courcoux, Charles-Antoine. "From Here to Antiquity: Mythical Settings and Modern Sufferings in Contemporary Hollywood's Historical Epics," Film \& History 39 (2009) 29-38.

dall'Asta, Monica. Un cinéma musclé: le surhomme dans le cinéma muet italien (1913-1926) (Crisnée: Yellow Now, 1992).

66 We gratefully acknowledge Mark Kyburz for his translation. 
"Maciste - ein Stereotyp westlicher Männlichkeit," KINtop 7 (1998) 84-97.

Davis, Natalie Zemon. Slaves on Screen. Film and Historical Vision (Cambridge, MA: Harvard University Press, 2000).

Douglas, Kirk. The Ragman's Son: An Autobiography (New York: Simon and Schuster, 1988).

Dyer, Richard. White (London: Routledge, 1997).

Eco, Umberto. "Die Struktur des schlechten Geschmacks," in Eco, Apokalyptiker und Integrierte. Zur kritischen Kritik der Massenkultur (Frankfurt am Main: S. Fischer, 1984) 59-115.

Fast, Howard. Being Red (Boston: Houghton Mifflin, 1990).

. Spartacus (New York: n.p., 1951).

Fiske, John. "Popular Culture," in Frank Lentricchia and Thomas McLaughlin, eds., Critical Terms for Literary Study (Chicago: University of Chicago Press, 1990) 321-335.

Futrell, Alison. "Seeing Red. Spartacus as Domestic Economist," in Sandra R. Joshel, Margaret Malamud, and Donald T. McGuire, Jr., eds., Imperial Projections: Ancient Rome in Modern Popular Culture (Baltimore: The Johns Hopkins University Press, 2001) 77-118.

Gibbon, Lewis Grassic [J. Leslie Mitchell]. Spartacus (London: Jarrold, 1933).

Hardwick, Lorna. Reception Studies (Oxford: Published for the Classical Association, 2003) [=Greece \& Rome: New Surveys in the Classics No. 33].

Hark, Ina Rae. "Animals or Romans. Looking at Masculinity in Spartacus," in Ina Rae Hark and Steven Cohan, eds., Screening the Male. Exploring Masculinities in Hollywood Cinema (London: Routledge, 1993) 151-172.

Hofmann, Heinz. "Spartacus," Progress Film Programm 5o, 1966 [four-page foldout].

Junkelmann, Marcus. Hollywoods Traum von Rom. "Gladiator" und die Tradition des Monumentalfilms (Mainz: P. von Zabern, 2004).

Kantorowicz, Ernst H. The King's Two Bodies. A Study in Mediaeval Political Theology (Princeton: Princeton University Press, 1957).

Koestler, Arthur. The Gladiators (trans. Edith Simon; London: J. Cape, 1939).

Kracauer, Siegfried. "Ben Hur," in Karsten Witte, ed., Kino: Essays, Studien, Glossen zum Film (Frankfurt am Main: Suhrkamp, 1974) 163-165.

__. "Geschichte und Fantasie," in Theorie des Films: Die Errettung der äusseren Wirklichkeit (Frankfurt am Main: Suhrkamp, 1984) 115-134.

Kreimeier, Klaus. "Der mortifizierende Blick: Von der Wiederkehr des Immergleichen im Monumentalfilm," in Jürgen Felix, Bernd Kiefer, Susanne Marschall, and Marcus Stiglegger, eds., Die Wiederholung (Marburg: Schüren, 2001) 325-334.

Lagny, Michèle. "Popular Taste: The Peplum," Richard Dyer and Ginette Vincendeau, eds., Popular European Cinema (London: Routledge, 1992) 163-180.

Landy, Marcia. Cinematic Uses of the Past (Minneapolis: University of Minnesota Press, 1996).

Lochman, Tomas, Thomas Späth, and Adrian Stähli, eds., Antike im Kino: auf dem Weg zu einer Kulturgeschichte des Antikenfilms (Basel: Verlag der Skulpturhalle Basel, 2008).

Renoir, Jean. Ecrits 1926-1971 (Paris: P. Belfond, 1974).

Ricoeur, Paul. Temps et récit (Paris: Seuil, 1984).

Rosen, Philip. Change Mummified. Cinema, Historicity, Theory (Minneapolis: University of Minnesota Press, 2001).

Rosenstone, Robert A. "History in Images/History in Words: Reflections on the Possibility of Really Putting History Into Film," American Historical Review 93 (1988) 1173-1185; reprinted in Robert A. Rosenstone, Visions of the Past. The Challenging of Film to Our Idea of History, Cambridge, MA: Harvard University Press, 1995) 19-44.

Schenk, Irmbert. "Von Cabiria zu Mussolini. Zur Geburt des monumentalen Historienfilms in Italien," in Malte Hagener, Johann N. Schmidt, and Michael Wedel, eds., Die Spur durch den Spiegel. Der Film in der Kultur der Moderne (Berlin: Bertz, 2004) 179-192.

Schlüpmann, Heide. "Die Geburt des Kinos aus dem Geist des Lachens," Frauen und Film 53 (1992) 87-94. 
Schöttker, Detlev. "Benjamins Bilderwelten. Objekte, Theorien, Wirkungen," in idem (ed.), Schrift, Bilder, Denken. Walter Benjamin und die Künste (Frankfurt am Main and Berlin: Suhrkamp, 2004) 10-31.

Shaw, Brent D. Spartacus and the Slave Wars. A Brief History with Documents (Boston, MA: Bedford/St. Martin's, 2001).

Shohat, Ella. "Gender and Culture of Empire: Toward a Feminist Ethnography of the Cinema," in Hamid Naficy, Teshome H. Gabriel, eds., Otherness and the Media: The Ethnography of the Imagined and the Imaged (Langhorne, PA: Harwood Academic Publishers, 1993) 45-84.

Sobchack, Vivian C. "Surge and Spendor: A Phenomenology of the Hollywood Historical Epic," Representations 29 (1990) 24-49.

Späth, Thomas. "Faits de mots et d'images. Les grands hommes de la Rome ancienne," Traverse 5 (1998) $35^{-5} 6$.

Szondi, Peter. Die Theorie des bürgerlichen Trauerspiels im 18. Jahrhundert: der Kaufmann, der Hausvater und der Hofmeister (Frankfurt am Main: Suhrkamp, 1973).

Tasker, Yvonne. Spectacular Bodies: Gender, Genre and the Action Cinema (London: Routledge, 1993).

Trice, Ashton D., and Samuel A. Holland. Heroes, Antiheroes and Dolts: Portrayals of Masculinity in American Popular Films, 1921-1999 (Jefferson, NC: McFarland, 2001).

Tröhler, Margrit, and Henry M. Taylor. "De quelques facettes du personnage humain dans le film de fiction," Iris 24 (1997) 33-57.

Turconi, Davide. "I film storici italiani e la critica americana dal 1910 alla fine del muto," Bianco e Nero 24 (1963) 40-56.

Urbainczyk, Theresa. Spartacus (London: Bristol Classical Press, 2004).

van Hooff, Anton J. De vonk van Spartacus. Het voortleven van een antieke rebe (Nijmegen: SUN, 1993).

Vanoye, Francis. Scénarios modèles, modèles de scenarios (Paris: Nathan, 1991).

Ward, C. Osborne. The Ancient Lowly. A History of the Ancient Working People from the Earliest Known Period to the Adoption of Christianity by Constantine 4 (Chicago: C.H. Kerr, 1907).

Weber, Max. "Die Entzauberung der Welt," in Weber, Wissenschaft als Beruf (Stuttgart: Reclam, 1995).

Winkler, Martin M., ed., Spartacus: Film and History (Malden, MA; Blackwell, 2007).

Wyke, Maria. Projecting the Past: Ancient Rome, Cinema, and History (New York and London: Routledge, 1997). 



\section{WITH YOUR SHIELD OR ON IT: \\ THE GENDER OF HEROISM IN ZACK SNYDER'S 300 \\ AND RUDOLPH MATÉ'S THE 300 SPARTANS}

\section{Thorsten Beigel}

Since Russell Crowe succeeded in 2000 as a gladiator not only in the virtual Colosseum in Rome but also at the box offices all over the world, antiquity has continued to provide a fashionable genre for directors and film producers. One of the recent examples of the genre is Zack Snyder's 30o, an adaptation from Frank Millers graphic novel about the last stand of the Spartans at Thermopylae 480 BC. ${ }^{1}$

Miller's award-winning graphic novel narrates the story of Leonidas and his men through the eyes of the sole Spartan survivor Dilios, who has been dismissed by Leonidas before the final battle in order to "make every Greek know what happened here."2 Starting with a flashback that deals with the young Leonidas surviving the last trial of the agoge and returning back to Sparta as king, the story line continues with the arrival of the Persian envoys demanding the submission to King Xerxes. Leonidas decides to kill them - the incident is related by Herodotus (7.133), though referring to the envoys of Xerxes' predecessor Darius - and to face the imminent attack at Thermopylae. But since the Ephors, bribed by the Persians, refuse to send out the entire army on religious grounds, Leonidas resolves to "take a stroll" to the Thermopylae accompanied by three hundred chosen warriors as his personal body guard. The further course of the story follows more or less the well-known outlines of the Herodotean account but from a exclusively Spartan point of view. ${ }^{3}$ The frontal assaults of the Persians fail with heavy casualties but the traitor Ephialtes - depicted as a heavily deformed Spartan who is refused membership in the three hundred - helps Xerxes to outflank the lines of the Spartans, who are annihilated in their famous last stand.

1 Frank Miller and Lynn Varley, 300 (Milwaukie, OR: Dark Horse Books, 1999).

2 As revealed at the end, Dilios tells the story on the eve of the battle of Plataea 479 BC.

3 The role of the Greek allies, represented by an Arcadian force, is heavily downplayed. Being amateurs in contrast to the Spartan professionals they engage only after the main work has been done. 
Zack Snyder's 300 closely follows Miller's narrative and seeks to imitate the visual artistry of the graphic novel by making lavish use of computer technology and special effects. As a consequence, the film looks more like a historical fantasy than a typical historical drama. Nevertheless, it is not entirely a shot-for-shot adaptation, but shows some marked differences. ${ }^{4}$ The most obvious is that Snyder added the subplot in which Gorgo, the wife of Leonidas, tries to convince the Spartan council to send reinforcement. Perhaps the most striking difference is the heavily biased depiction of the Persians which significantly exceeds the original. While the Spartans are depicted as semi-nude, overly masculine heroes, their Persian counterparts appear as effeminate or even include such monstrous and grotesquely disfigured characters as the "Berserker" and the "Executioner." The Persians use weapons like a giant rhinoceros or grenades hurled by magicians and commit atrocities to civilians. Nevertheless, even their sinister, ninja-like elite corps, the Immortals, is no match for the brave Spartans. Soon after its release, the film engendered a controversial reception. The uncritical celebration of Spartan heroism and the biased depiction of the Persians brought protest upon Snyder for fostering racist, homophobic, and even fascist ideas. ${ }^{6}$ Also, popular culture parodies like Meet the Spartans and United 300 can be understood as a reaction to the blunt use of such cultural and sexual stereotypes. ${ }^{7}$

Since 300 focuses on a specific form of male heroism which Snyder (and probably the majority of the film audience as well) considers typically "Spartan", it may seem paradoxical to write about the role of women in this film. However, Snyder's portrayal of his male heroes does not depend on only the Spartiates themselves but also on the contrastive interplay between Leonidas and his men on the one hand and their counterparts on the other hand. Thus the digitally perfected, semi-nude bodies of the Spartans stand in contrast to the monstrous, disfigured horde of their Persian enemies, and the androgynous portrayal of King Xerxes as well as the derisive remarks about "boy-loving" Athenians and Arcadian amateurwarriors serve to sharpen the idealization of the Spartan protagonists. Even within the Spartan cosmos counterparts to the brave and straightforward heroes can be found, such as the corrupt politician Theron or the Ephors,

4 Cf. G.N. Murray, "Zack Snyder, Frank Miller and Herodotus: Three Takes on the 300 Spartans," Akroterion $5^{2}$ (2007) 11-35.

5 See Jeroen Lauwers, Marieke Dhont \& Xanne Huybrecht in this volume.

6 Lauwers in this volume and Murray, "Zack Snyder, Frank Miller and Herodotus," 12f.

7 Ralph Poole in this volume. 
who are depicted as boil-covered, lecherous old priests. Drawing on the example of Leonidas' wife Gorgo, this paper seeks to analyze in what way female gender roles contribute to the construction of male heroism. It will be demonstrated how the character of Leonidas is shaped by the portrayal of his wife, particularly when compared to Miller's original graphic novel. Finally, the comparison with Rudolph Mate's The 300 Spartans (1962) will show a different method of using gender stereotypes.

One thing that can be clearly stated about Miller's graphic novel is that women are virtually absent. Gorgo appears once only when the three hundred decamp.

In Miller's typically expressive style, highlighted with dynamic facial expressions and an imperious gesture, she supports Leonidas' plan to leave for the "Hot Gates," i.e., Thermopylae. The subsequent farewell of the married couple is truly "laconic" and does not allow any time for sentimental emotions (see below). Only at the end of the film does the fatally wounded Leonidas think of wife again.

In contrast, Snyder creates for the character of Gorgo a much greater role. At the beginning of the central story he focuses first on the royal family in their private quarters, and only then does he bring in the Persian envoy who abruptly interrupts them. Unlike Miller, Leonidas gains here an important facet. While Miller portrays him merely as the dutiful King, Snyder first of all establishes Leonidas as an affectionate father and husband. In the following scene the queen takes it for granted that she is allowed to participate in the hearing with the envoy and even addresses him at a personal level. To his indignant enquiry, "What makes this woman think she can speak among men?" she replies with a well-known Spartan apophthegm: "Because only Spartan women give birth to real men." ${ }^{8}$ As the story continues Gorgo is the one who ultimately motivates Leonidas to make his irreversible decision: before the king forces the Persian envoy into a deep cistern, he looks around to his wife to reassure himself that she concurs with his actions. Not until she nods in agreement does he carry out his plan, which provides the casus belli for Xerxes.

Gorgo appears in both scenes as an active, self-confident wife and queen who advises and supports her husband. This continues in the

8 See Plut. Lyc. 14.4: When some foreign woman, as it would seem, said to her: "You Spartan women are the only ones who rule their men," she answered: "Yes, we are the only ones that give birth to men." and Plut. Mor. 240 E 5 (Sayings of Spartan women): Being asked by a woman from Attica, "Why is it that you Spartan women are the only women that lord it over your men," she said, "Because we are the only women that are mothers of men." 
following scenes. Pretending religious objections (but in fact being bribed with Persian gold), the Ephors refuse to pursue Leonidas' plan to send out the entire Spartan army against the Persians. At night, when the sleepless Leonidas is brooding over his further steps, Gorgo urges him to act as a "free man" and to do everything necessary for the sake of Sparta. ${ }^{9}$ The dialog evolves into love-making, which gives the director the opportunity to display the completely nude bodies of his protagonists. While the film uses male semi-nudity otherwise as a symbol for military heroism (clearly a reference to "heroic nudity"), Leonidas and Gorgo serve here as a specimen of an idealized sexuality, thus forming a contrast to deviant forms of sexuality as, for instance, in the rape of Gorgo or the sexual orgy in Xerxes' tent.

As a preliminary result it can be stated that Snyder's Leonidas is portrayed not only as a king and warrior but also, due to the role of Gorgo, as a loving husband and father. Accordingly Gorgo appears as a wife and mother but nevertheless a queen who stands by her king's side and consequently subordinates her own fortune to the welfare of the state. The farewell scene, when Leonidas and the three hundred decamp to the Thermopylae, reflects that particular relation. First, helmet and shield are handed over to Leonidas by his wife and his son, and then Gorgo gives an amulet to her husband, which will be returned at the end of the film by the sole survivor of the three hundred, the narrator Dilios. For the last time Leonidas is depicted as husband/father and king/warrior. Gorgo accordingly speaks as both wife and queen when she says: "Come back with your shield or on it,"10 thereby proving herself a true Spartan woman. ${ }^{11}$

Compared to the corresponding scene in Miller's graphic novel the difference is quite obvious even though the dialog is exactly the same as in the film:

Gorgo: Spartan!

Leonidas: Yes, my lady?

Gorgo: Come back with your shield, or on it.

Leonidas: Yes, my lady.

9 Cf. Plut. Mor. 240 E "As she (sc. Gorgo) was encouraging her husband Leonidas, when he was about to set out for Thermopylae, to show himself worthy of Sparta..."

10 Again adapted from Plut. Mor. 241 F 16 (Sayings of Spartan women): "Another, as she handed her son his shield, exhorted him, saying, 'Either this or upon this.' " It is notable that such apothegms are related to Spartan mothers exhorting their sons, presumably because young soldiers were more likely to tremble in their first battle; see Sarah B. Pomeroy, Spartan Women (Oxford: Oxford University Press, 2002), 57

11 For the ideology of motherhood see ibid. 
Despite the similarity in dialog, in the graphic novel the couple concludes with a rather cool farewell. Gorgo merely alludes to a love act, which is not depicted by Miller, and this is rationalized by Leonidas' reply: "Sparta needs sons." 12

Whereas up to this point Gorgo appears only when she is together with her husband, she assumes a leading role in the domestic Spartan subplot after the three hundred decamp. Her endeavour to persuade the Spartan council to send out the entire army compels her to make a deal. She finds herself forced to agree to give herself to the corrupt councillor Theron in exchange for his support and the implementation of her plan. However, the act itself becomes a veritable rape - accompanied by Theron's malicious comment:

This will not be over quickly. You will not enjoy this. I'm not your King.

The petrified Gorgo endures this in front of the entrance of her house. In the following council meeting, however, Theron does not stick to the bargain and furthermore accuses Gorgo of adultery. Thereupon Gorgo wrests a sword away from a guard and stabs her adversary. The Persian coins that fall from his vestments immediately reveal Theron as a traitor. At the same time Gorgo, still holding the sword plunged into his belly, repeats Theron's words:

This will not be over quickly. You will not enjoy this. I am not your Queen! Clearly both scenes have a profound symbolic significance. Although Gorgo initially agrees to give herself to Theron and drops her dress off her shoulders as a sign of consent, the act at last becomes a rape when Theron brutally turns her around (thus being a pivotal moment in two respects) and pins her against the wall (see Figure 1$).{ }^{13}$ Consequently, by analogy Theron also suffers a penetration - but in his case with fatal consequences (see Figure 2).

Furthermore, the brute violation committed by Theron constitutes a striking antithesis to the preceding love act between Gorgo and Leonidas, and this is paralleled by the sites where both acts take place. That is, Leonidas and Gorgo lie in their bed inside their house whereas Gorgo gets raped standing at the entrance to her house, i.e., the inviolable border of

\footnotetext{
12 Obviously an allusion to Plut. Mor. 240 E 6 (Sayings of Spartan Women): "[Gorgo] asked what she should do; and he said, 'Marry a good man, and bear good children.' "

${ }^{13}$ I would like to thank the participants of the conference for their useful comments on that point.
} 


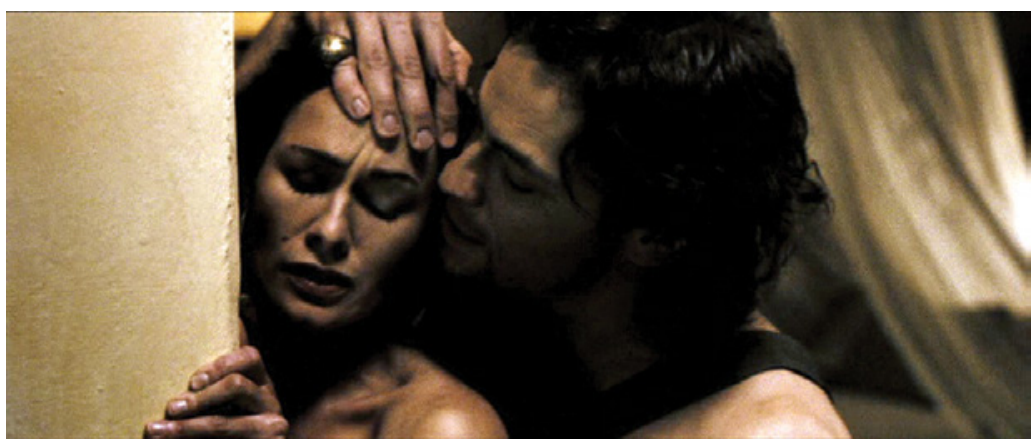

Figure 1

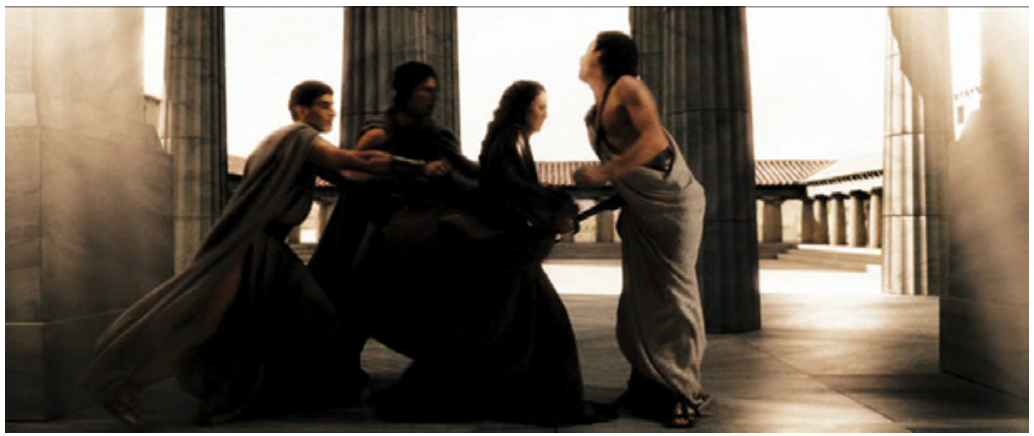

Figure 2

their home. Significantly, Gorgo takes public revenge in Theron's "house," the council chamber that Theron has claimed to own "as if it were build by my own hands." Therefore, these three scenes can be seen as a triptych that serves in part to distinguish the hero Leonidas from his adversary Theron. While Leonidas embodies the role of the loving husband and manly "warrior," Theron plays the part of the rapist and villainous "politician." The film shows us this also in their different visual presence. Even though both are Spartiates, only Leonidas is depicted as a semi-nude "warrior," while Theron always appears fully dressed. This triptych also serves to portray Gorgo as the female hero who is willing to endure Theron's sexual assault for her husband's and Sparta's sake. As a strong woman, she is also capable of taking revenge into her own hands - very much unlike, for example, the legendary Lucretia - thereby proving herself the appropriate counterpart to Leonidas. 
Snyder puts Gorgo's role as the ideal of a Spartan woman and queen into high relief as well by also depicting deviant forms of femaleness. As a case in point, he represents the oracle Pythia as a beautiful young woman. While uttering unintelligible sounds in the state of trance, her barely veiled body (probably a concession to the male demographic of the audience) is exposed to the sexual assaults of the lecherous and disfigured Ephors. As in the rape of Gorgo, a female body is abused by a counter-image of masculinity, thus forming a marked contrast to the royal couple's love act. In addition, the camera does not frame (the) Pythia as an independently individualized person but as merely a body.

Even the Persians provide another example of deviant femaleness: when the grotesquely disfigured traitor Ephialtes seeks out Xerxes' tent to offer his services to the "God-King," he enters a decadent and almost surreal setting. At first there is a seemingly familiar sight of an oriental court with lascivious dancing women. But suddenly the situation changes and the astonished Ephialtes (as well as the audience) is confronted with lesbian caresses. Finally, one of dancers displays the disfigured side of her face by turning her head, thus disclosing symbolically the shady side of Persian tryphe behind the attractive façade. This scene seamlessly conforms with the defaming depiction of the Orientals as disfigured and sexually deviant counterparts of the Spartiates, whose ideals - physically as well as sexually - are represented by Leonidas and Gorgo. In comparison to Frank Miller's graphic novel, Zack Snyder in both instances exceeds the original and sharpens the antagonism between his heroes and their enemies.

Therefore Snyder employs the role of Gorgo in several respects. On the one hand he broadens the character of Leonidas in comparison to Miller's original by depicting him not only as a king and warrior but also as a husband and father. Certainly this helps to soften the severity of the graphic novel and makes the film character accessible for a wider audience. Furthermore, the character of Gorgo offers a figure of identification to the female audience. At the same time her role permits the implementation of an additional sub-plot that helps to distinguish the hero Leonidas from a Spartan adversary like Theron. On the other hand, Gorgo's character serves to underscore the portrayal of Leonidas as the brave, masculine ideal as opposed to the villain Theron or the sexually ambiguous Persian King. Finally, Gorgo completes the construction of the Spartan myth, which Miller had exclusively defined in terms of male bravery, whereas Snyder assigns a female "co-hero" to his main character Leonidas.

For the characterization of Gorgo Snyder draws on a number of sources for inspiration, including such well-known elements of the classical 
tradition as quotations from Plutarch. As a consequence, her role seems to be consistent with the exceptional position of Spartan women attested by our ancient sources. ${ }^{14}$ Both laconophile writers like Xenophon or Plutarch as well as critics like Aristotle, who blamed the gynaikokratia for the decline of Sparta, agree that Spartan women enjoyed more freedom and equality than elsewhere in Greece. The key elements of the image of Spartan women are their comparatively high autonomy from men, the great importance of motherhood, a marked self-confidence, and beauty and physical fitness as well as the revealing dresses which alienated other Greeks and led to the nickname phainomerides ("thigh showers"). Hence, women have helped to shape the Spartan myth nearly as much as the Spartiates themselves.

In spite of the comparatively ample evidence about Spartan women in general, little is known about individual historical women like Gorgo. Although she is mentioned by Herodotus and Plutarch several times, the historical figure is contaminated by legendary elements. Herodotus (5.51.1-3) relates that as a child Gorgo warned her father, King Cleomenes I, about Aristagoras, the tyrant of Miletus, who offered a huge sum to persuade Cleomenes to support his rebellion against Persia: ${ }^{15}$

(1) [Aristagoras] first asked Cleomenes to send away the child, his daughter Gorgo, who was standing by him. She was his only child, and was about eight or nine years of age. Cleomenes bade him say whatever he wanted and did not let the child's presence hinder him. (2) Then Aristagoras began to promise Cleomenes from ten talents upwards, if he would grant his request. When Cleomenes refused, Aristagoras offered him ever more and more. When he finally promised fifty talents the child cried out, "Father, the stranger will corrupt you, unless you leave him and go away." (3) Cleomenes was pleased with the child's counsel and went into another room while Aristagoras departed from Sparta, finding no further occasion for telling of the journey inland to the king's palace.

Another story (Hdt. 7.239) reports that Gorgo has helped to discover a secret message sent by the exiled king Demaratos to warn the Spartans about the imminent Persian attack. The historical veracity of such

14 The real extent of these differences, however, is still open to debate. See Lukas Thommen, "Spartanische Frauen," Mus. Helv. 56/3 (1999) 129-149, and Pomeroy, Spartan Women.

15 Cf. Plut. Mor. 240 D 1 "Gorgo, daughter of king Cleomenes, when Aristagoras of Miletus was urging her father to enter upon the war against the Persian king in behalf of the Ionians, promising a vast sum of money, and, in answer to Cleomenes' objections, making the amount larger and larger, said, 'Father, the miserable foreigner will be your ruin if you don't get him out of the house pretty soon!" 
anecdotes is certainly doubtful but it can at least be stated that Spartan women advising her fathers or husbands were not wholly incredible to Herodotus or his audience. ${ }^{16}$ Our second source, Plutarch, ascribes several apophthegms to Gorgo employed in the film. ${ }^{17}$

At first glance Snyder's Gorgo fits quite well into the ancient paradigm of a Spartan woman. She is self-confident and able to assert herself even against men. Being an equal partner with Leonidas, both as a wife and a queen, she is willing to subordinate her personal well being to that of the state. And last but not least, the sayings which Plutarch attributes to the historical Gorgo are meant to give additional credibility to the film character. Nevertheless this cannot hide the fact that Gorgo's character is actually in essence a modern construction of femaleness. Not for nothing Snyder omits, for example, the permissiveness and nudity for which Spartan women were notorious in antiquity. ${ }^{18}$ In fact, what Snyder does is depict a modern ideal of a married couple within the world of classical Sparta.

This is a characteristic feature of the entire film which makes selective use of single elements of the classical tradition mixed with modern conceptions, thus producing an unhistorical amalgam. ${ }^{19}$ And so, a large number of critics considered 300 historically inaccurate. ${ }^{20}$ On the other hand, such distinguished scholars as Victor Davis Hanson and Mary Bean insisted that a film which uses several more or less historical details cannot be that wrong. ${ }^{21}$ However, such quarrels seem rather futile for the issue at stake, which is to examine how a cinematic (re)construction of historical myths and themes works.

16 Cf. Pomeroy, Spartan Women, 57 and 46.

17 On the Laconian Apothegms see Eugéne Napoléon Tigerstedt, The Legend of Sparta in Classical Antiquity, vol. 2 (Uppsala: Almqvist \& Wiksell, 1974) 16-30.

18 See Pomeroy, Spartan Women, esp. 14-6, and Paul Cartledge, "Spartan Wives: Liberation or License?" CQ 31 (1981) 84-105.

19 Cf, Touraj Daryaee, "Go tell the Spartans" Iranian.com, March 14, 2007, http://www iranian.com/Daryaee/2007/March/300/index.html: "Some passages from the Classical authors Aeschylus, Diodorus, Herodotus and Plutarch are spilt over the movie to give it an authentic flavor.... Classical sources are certainly used, but exactly in all the wrong places, or quite naively."

20 See, e.g., Ephraim Lyrtle, "Sparta? No. This is madness," Toronto Star, March 11, 2007, http://www.thestar.com/article/190493.

21 Victor D. Hanson, "History and the Movie 30o," private paper, October 11, 2006, http:// victorhanson.com/articles/hanson101106PF.html and Mary Beard, “A Don's Life: 10 Things The Makers of '30o' Got Right,” Times Online, October 3, 2007, http://timesonline.typepad .com/dons_life/2007/10/10-things-the-m.html. 
The use of "authentic" elements is a key feature of the legitimating strategy of historical films, even perhaps for any historical re-narration. One may think, for instance, of the chariots or the boar's tusk helmet in Homer's Iliad. For historians, the question of continuity and change of such constructions seems to be more important than debating the historic accuracy of blockbuster films. In the case of 300 , the 1962 Cinemascope film The 300 Spartans provides a possibility of comparison. ${ }^{22}$ Frank Miller, who saw the film at the age of seven, claimed that "this clunky old movie from 2oth Century Fox" inspired him to create his graphic novel..$^{23}$

The plot of Rudolph Matés film, which was written by George St. George, a host of Italian co-writers, and Paul Nord (credited as the "Historical Story Adviser"), can be summarized as follows. Threatened by the advance of Xerxes' army, the Greek states agree to defend the pass at Thermopylae under the leadership of the Spartan king Leonidas while the Athenian fleet is supposed to secure the seaside at Cape Artemision. Since the Spartan authorities refuse the immediate decampment of the entire Spartan army on religious grounds, Leonidas decides to defend the pass with only his own bodyguard of three hundred men and a small contingent of Greek allies. The Persian forces are repulsed with heavy losses, and Xerxes is nearly captured during a Spartan night attack on his camp, but with the help of the traitor Ephialtes, a sinister shepherd, the Persians manage to bypass the Greek positions and annihilate the Spartans by arrows.

A subplot tells the romantic love story of the young Spartiate Phylon and his fiancée Ellas. Since his father is considered as a traitor, Leonidas barres Phylon from the ranks of his corps. Nevertheless, Phylon, accompanied by Ellas, follows the three hundred secretly to fight with them and wipe out his disgrace. Due to his bravery in battle, Phylon is rehabiliated by Leonidas and sent back to Sparta with his fiancée, thus being the only Spartan survivors of the battle.

Like 30o, Maté's narrative unfolds under the overarching theme derived from the juxtaposition of Greek freedom and Persian tyranny. But whereas

22 For a fuller treatment of the film, see David S. Levene, "Xerxes Goes to Hollywood," in Emma Bridges, Edith Hall, and Peter John Rhodes, eds., Cultural Responses to the Persian Wars. Antiquity to the Third Millennium: 383-403 (Oxford: Oxford University Press, 2007) and Fernando Lillo Redonet, "Sparta and Ancient Greece in 'The 300 Spartans," in Irene Berti and Marta Garcia Morcillo, eds., Hellas on Screen: Cinematic Receptions of Ancient History, Literature and Myth (Stuttgart: Franz Steiner Verlag, 2008) 117-130.

23 D.R. Epstein, "Frank Miller, 300 Interview," Under Ground Online, accessed December 10, 2007, http://www.ugo.com/ugo/html/article/?id=16424. 
Snyder's portrayal of the Orientals can clearly be seen as a post-9/11 product, The 3 oo Spartans must be understood against the background of the Cold War. ${ }^{24}$ The different contexts of origin and reception of both films also become apparent in their representation of gender relations. Considering the role of Gorgo, her first appearance in Maté's film seemingly corresponds with the portrayal of Snyder's heroine. The scene depicts the initiation ceremony of the Spartiate Phylon, where Gorgo reminds the young man of the Spartan virtues and presents him with his shield. The solemnity of this rite of passage is underlined by her exhortation, to come back with his shield or upon it. Maté's Gorgo actually cites it in Greek, the meaning of her words being explained to the audience by a dialog between two other actors:

Gorgo: I'm giving you this shield. There are but five words to remember: e tan e epi tas

Woman: What does this it mean?

Ellas: With this or on this. Either come home victorious with this shield, or dead on it.

Just like Snyder, Maté portrays the queen as a personification of the ideal Spartan woman already known in classical antiquity. The quotation - just as in 300 - serves to create an "authentic" image of the Spartan way of life. However, the ensuing scenes show a marked difference between the two films. Maté's Gorgo appears only inside the house as the traditional place of a Greek woman (although Spartan women were rather an exception to the rule $)^{25}$ but not in the public sphere, let alone in the Gerousia like her counterpart in 30o. She also lacks the poise of her modern successor and is no match for her husband or other men. Consequently, she does not succour and advise her husband, but, even worse, serves as a virtual obstacle for the male hero. When Leonidas tells his wife that he is about to leave for Thermopylae with only three hundred men, Gorgo is anxious about his safety, so she implores him to wait until the entire Spartan army is ready to encamp. Leonidas, reminding her of his duty, stands firm. Hence, while Snyder's Gorgo plays an active part in the plot and provides at least two decisive stimuli for her husband, their relation in The 300

\footnotetext{
24 See Levene, "Xerxes Goes To Hollywood," 383ff. and Lillo Redonet, "Sparta and Ancient Greece in 'The 300 Spartans."”

25 For the social power and political influence of Spartan women see Pomeroy, Spartan Women, esp. 92f. and Maria Dettenhofer, "Die Frauen von Sparta: Gesellschaftliche Position und politische Relevanz," Klio 75 (1993) 61-75.
} 
Spartans is quite the other way around, for in the earlier film Leonidas has to prove himself a hero by ignoring the concerns of his wife.

The same pattern of behaviour can be found in the aforementioned subplot. After Phylon is barred from the ranks of the three hundred, his fiancée urges him to follow Leonidas secretly because she wants him to wipe out his disgrace and prove himself as a proper Spartiate (thereby, as a by-product, enabling him to marry her). Ellas fully identifies herself with Spartan values and even accompanies her fiancé on his way to the Thermopylae, where they find shelter in the hut of an old shepherd and his wife. While Philon is eager to engage, she becomes acquainted with the quiet and simple life of her hosts - not unlike Philemon and Baucis - and gradually dissociates herself from Spartan values. Therefore, Ellas dreams of a long and happy life with Phylon and wants to stop him from taking part in the battle. Here again, the male hero ignores a woman's concerns and wishes - and is proven right by the outcome of the story.

Significantly, the only strong female figure in Maté's film can be found on the Persian side, namely, Artemisia, ruler of Halicarnassos and Xerxes' ally. She is a self-aware and powerful adviser to the king, who is captive to her charm. Being more influential than any man in Xerxes' entourage, Artemisia knows how to use her position (and the King's obvious advances) for her own interests. Artemisia clearly represents a femme fatale and therefore serves - at least in terms of the 196os - as a negative female role model, especially because she is, unlike her Spartan counterparts, a powerful woman. Maté's film therefore displays a chiastic structure of gender relations: on the one hand the Spartan heroes Leonidas and Phylon, who have to prevail against their loving but ultimately weak women, and on the other hand the irascible and cruel tyrant Xerxes, who falls captive to the strong woman Artemisia.

To sum up, the analysis of Zack Snyder's film and the comparison with Frank Miller's graphic novel as well as Rudolph Maté's The 3 oo Spartans sheds light on the construction of male heroism by means of gender stereotypes. In contrast to Miller's 300 , where women are virtually absent, Gorgo's character is in many respects particularly important for Snyder's film. She offers a figure of identification to the female audience and softens the severity of the graphic novel, thus making the film accessible for a wider audience. Furthermore, she appears - at least at first glance - as a typical representative of a Spartan woman, giving a sort of authenticity to the film which is supported by the use of ancient sources, like the quotations from Plutarch. But above all Gorgo's role helps to distinguish the character of Leonidas as the male protagonist. As his adviser and 
companion she endorses his crucial decisions; together with her husband they represent the ideal couple in moral as well as sexual terms. The love-making between Leonidas and Gorgo forms a marked contrast to the sexual assaults of the Pythia by the Ephors and Theron's rape of Gorgo as well as the erotic temptations that Ephialtes witnesses in Xerxes' tent. Thus, due to the role of Gorgo, Leonidas is portrayed as the right-minded, heterosexual hero in contrast to the villain Theron, the lecherous Ephors, and the androgynous King Xerxes.

Similarly, Maté uses the female characters in his film as a means of characterizing the men, but according to the Zeitgeist of the 1960 s the gender relations work just the other way around. ${ }^{26}$ Leonidas and Phylon prove themselves Spartiates and heroes by prevailing against their women, while the tyrant Xerxes, who threatens the Greeks with slavery, turns out to be captive to Artemisia.

It is a commonplace that the cinematic reconstruction of history depends heavily on contemporary conceptions. In most instances antiquity merely serves as a framework, and as a consequence authentic ancient elements - such as the quotations drawn from Plutarch - are more or less used as set-pieces. Thus, 300 and The 300 Spartans reveal more about the change of gender relations from the 1960's to now. And finally, in spite of their different usage of female gender roles, both films illustrate the interdependence of (modern) gender constructions: precisely because both display such a pronounced image of male heroism, they are in need of corresponding female counterparts.

\section{Works Cited}

Beard, Mary. “A Don's Life: 10 Things the Makers of '30o' Got Right," Times Online, October 3, 2007, http://timesonline.typepad.com/dons_life/2007/10/10-things-the-m.html.

Cartledge, Paul. "Spartan Wives: Liberation or License?" CQ 31 (1981) 84-105.

Daryaee, Touraj. "Go Tell the Spartans," Iranian.com, March 14, 2007, http://www.iranian .com/Daryaee/2007/March/300/index.html.

Dettenhofer, Maria. "Die Frauen von Sparta: Gesellschaftliche Position und politische Relevanz," Klio 75 (1993) 61-75.

Epstein, D.R. "Frank Miller, 300 Interview," Under Ground Online, accessed December 10, 2007, http://www.ugo.com/ugo/html/article/?id=16424.

Hanson, Victor D. "History and the Movie 30o," private paper, October 11, 2006, http:// victorhanson.com/articles/hanson101106PF.html.

26 Lillo Redonet, "Sparta and Ancient Greece in "The 300 Spartans," 117: "The movie broadcasts indeed a reinvented picture of historical Sparta according to the cultural taste and the historical context of 1961." 
Levene, David S. "Xerxes Goes to Hollywood," in Emma Bridges, Edith Hall, and Peter John Rhodes, eds., Cultural Responses to the Persian Wars. Antiquity to the Third Millennium: 383-403 (Oxford: Oxford University Press, 2007).

Lillo Redonet, Fernando. "Sparta and Ancient Greece in 'The 300 Spartans'," in Irene Berti and Marta Garcia Morcillo, eds., Hellas on Screen: Cinematic Receptions of Ancient History, Literature and Myth (Stuttgart: Franz Steiner Verlag, 2008) 117-130.

Lytle, Ephraim. "Sparta? No. This is madness," Toronto Star, March 11, 2007, http://www .thestar.com/article/190493.

Miller, Frank and Lynn Varley, 300 (Milwaukie, OR: Dark Horse Books, 1999).

Murray, G.N. "Zack Snyder, Frank Miller and Herodotus: Three Takes on the 300 Spartans," Akroterion $5^{2}$ (2007) 11-35.

Pomeroy, Sarah B. Spartan Women (Oxford: Oxford University Press, 2002).

Thommen, Lukas. "Spartanische Frauen," Mus. Helv. 56/3 (1999) 129-149.

Tigerstedt, Eugéne Napoléon. The Legend of Sparta in Classical Antiquity, vol. 2 (Uppsala: Almqvist \& Wiksell, 1974). 


\title{
"THIS IS SPARTA!" \\ DISCOURSE, GENDER, AND THE ORIENT IN ZACK SNYDER'S 300
}

\author{
Jeroen Lauwers, Marieke Dhont and Xanne Huybrecht
}

Zack Snyder's 2006 film 30o, which is based on Frank Miller's 1998 graphic novel, ${ }^{1}$ tells the heroic story of the Spartan king Leonidas and his three hundred men. Because Leonidas is forbidden by the oracle and her priests from leading the Spartan army against the mighty Persian god-king Xerxes, he decides to head north himself with a "personal bodyguard" of three hundred of his finest men. This relatively small number of soldiers, joined by an auxiliary Arcadian force, holds the countless number of Persian soldiers back for no fewer than three days. Meanwhile in Sparta, Queen Gorgo works to have the Spartans send additional men to Thermopylae to rescue her husband and his Three Hundred, but her efforts are thwarted by the treason of the politician Theron. ${ }^{2}$

Ever since the movie's release, critical and popular opinions have advanced many different perspectives. A rather large number of people have found diverse reasons for considering 300 offensive. One aspect of this critique revolves around its so-called homophobia, ${ }^{3}$ for example, in the scene in which Leonidas arrogantly calls the Athenians "those philosophers and boy-lovers." Others vituperate the movie for its supposed fascist ideals, pointing out uncanny parallels between the Spartan society and the "Third Reich": the extreme nationalism, the mutual equality of the Spartiates and their superiority to the helots, the (primitive) genetic selection, and considering women as breeding machines for an ideal fighting

1 The movie quite strictly follows the design and the perspective of the graphic novel. Snyder even stated publicly that the film 300 is "probably about ninety percent the book" ("Interview with Zack Snyder," accessed November 30, 2011, http://www.latinoreview.com/ news/interview-zack-snyder-on-300-1558). However, since the present book is about antiquity in film, we focus almost exclusively on the movie.

2 Gorgo's name is never explicitly mentioned in the movie, but, following the ancient sources, IMDb lists Lena Headey's character as "Queen Gorgo."

3 E.g., François Peneaud and Joe Palmer, "Frank Miller and 30o's Assault on the Gay Past," AfterElton.com, March 5, 2007, http://www.afterelton.com/movies/2007/3/300.html. Interestingly, the Spartans can also be suspected of being crypto-homosexual; cf. (also for a discussion of the Iranian reception) Richard Corliss, " 7 Reasons Why 300 Is a Huge Hit," Time, March 14, 2007, accessed November 30, 2011, http://www.time.com/time/arts/ article/o,8599,1598977,0o.html. 
elite. ${ }^{4}$ Yet another accusation is $30 o^{\prime}$ s so-called facile embrace of racism towards modern Iran, the geographical, ethnic, and cultural descendant of ancient Persia. ${ }^{5}$ Some of the Persians in 300 are depicted as deformed or monstrous, sometimes even barely recognizable as human beings, and others are depicted as stereotypical and banal representatives of Western orientalism - effeminate, decadent, exotic.

In response to these ready-made and superficial criticisms, we aim to take the discussion to a deeper level, identifying and tracing the different forms of social discourse (both ancient and modern) which run throughout the movie. We will try to uncover the naturalizing processes in gender definition, in which the norms of the ancient narrator are manifestly reconstituted in the conventions of the genre of the modern action movie. By deconstructing this self-evident link between two historical forms of discourse, and by showing the historical discrepancy between both worlds in which they are performed, we aim to demonstrate how 300 can avail us of the opportunity to question the "natural" dominance of masculine discourse in our contemporary society. In doing so, we hope to achieve a refined historical assessment of gender as it is described, for example, by Judith Butler:

Gender ought not to be construed as a stable identity or locus of agency from which various acts follow; rather, gender is an identity tenuously constituted in time, instituted in an exterior space through a stylized repetition of acts... This formulation moves the conception of gender off the ground of a substantial model of identity to one that requires a conception of gender as a constituted social temporality. ${ }^{6}$

To do so we will provide more insight into the communicative value of the storytelling, and this equally for the characters in the movie as well as for the director of the film and his audience. Subsequently, we will address the depiction of gender and the Orient, neither of which can be thought apart from the other. Finally, we will turn our attention to the way in which 300 offers a remarkable example of the reception of classi-

4 Even Susan Sontag's terminology of "fascist art" is used to categorize this movie. See Roger Moore, “300 As Facist Art,” Orlando Sentinel Entertainment/Movies Blog, March 7 , 2007, accessed November30, 2011, http://blogs.orlandosentinel.com/entertainment_movies_ blog/2007/03/300_as_fascist_html.

5 See "Iran Condemns Hollywood War Epic," BBC News, last updated March 13, 2007, accessed November 30, 2011, http://news.bbc.co.uk/2/hi/6446183.stm for an online BBC news report about the reception of 300 in Iran.

6 Judith Butler, Gender Trouble (7th ed.; New York and London, Routledge, 2010) 191. 
cal antiquity, which is not entirely unprecedented but might never before have reached such an intense level of controversy.

\section{The Narratological Perspective ${ }^{7}$}

Throughout the entire film, the events are reported by one particular masculine narrator, Dilios, a soldier who fought in Thermopylae, and, as we learn later in the film, has been ordered by Leonidas himself to save his life and tell the Spartans and the other Greeks about the king's glorious sacrifice. Dilios underlines his own participation in this event by speaking of the Spartan heroes in the first person plural:

We march. For our lands, for our families, for our freedom. We march.

For the majority of the film, therefore, the story is told by a homodiegetic narrator who was in Thermopylae as a (one-eyed) eye-witness but who also adds elements to his story that he could not have witnessed himself, for instance, the encounter between Xerxes and Leonidas, and the interlude in Sparta. Moreover, during the scene in which Dilios leaves Thermopylae to fulfill his destiny, he does not talk about himself in the first person singular, which seems to imply that he does not consider himself to be at the center of the action, but rather as a mere extra in the grand tale about his king. In Dilios' narration, we thus find a tension between, on the one hand, the need to affirm his own presence among the Three Hundred in order to render his discourse at the same time more vivid and more credible, and, on the other, a more general perspective, which sketches the whole picture and allows the narrator to embellish his rhetorical discourse. An excellent example of the latter aspect is the analogy between the killing of the wolf in a narrow passage at the beginning of the movie and the subsequent battle against the great Persian "beast" in the narrow Hot Gates.

7 For this section, we mostly use the literary model of Mieke Bal in Narratology: Introduction to the Theory of Narrative (2nd ed.; Toronto: University of Toronto Press, 1997), which is also adopted, particularly with regard to film, by Peter Verstraten, Handboek filmnarratologie (2nd ed.; Nijmegen: Vantilt, 2008).

Note, however, that these insights are not generally accepted, especially not by the founding father of narratology, Gérard Genette, Narrative Discourse Revisited (trans. Jane E. Lewin; Ithaca, N.Y.: Cornell University Press, 1990) 72-78. Nevertheless, this theoretical framework is well-established and offers a sound basis for a narratological analysis. 
Dilios' narration is constructed with a clear purpose. The closing scene of the movie reveals that his tale has been designed to inspire and encourage his fellow soldiers just before the definitive battle in Plataea:

Just there the barbarians huddle, sheer terror gripping tight their hearts with icy fingers - knowing full well what merciless horrors they suffered at the swords and spears of three hundred. Yet they stare now across the plain at 10,000 Spartans commanding 30,000 free Greeks. The enemy outnumbers us a paltry 3 to 1, good odds for any Greek. This day we rescue a world from mysticism and tyranny and usher in a future brighter than anything we can imagine. Give thanks, men, to Leonidas and the brave Three Hundred. To victory!

The narration therefore recounts and organizes all the events in retrospect. The speech is a carefully composed narration in service of pro-Greek and anti-Persian propaganda. Therefore, one cannot expect Dilios' words to offer a detached or objective description. The events and characters in his speech have undergone the mediation of cultural ideas, stereotypes, discourses, and beliefs.

Up to this point, we have deliberately - for the sake of the argument ignored the intervention of an external narratological agent, i.e., the film's director. Nonetheless, the latter's function should not be underestimated. After all, it has been Zack Snyder's choice to take Dilios' standpoint as the discursive basis for his own narration about the famous battle, albeit heavily influenced by Miller's graphic novel. ${ }^{8}$ Furthermore, Snyder does not limit the film to a portrait of the man behind Dilios' voice-overs but offers instead a real-life visual equivalent of the latter's narrative. During this mise-en-scène, he often bans Dilios to the background to create a more direct and vivid visual realization. Too many references to the fact that the film is the visual pendant of a Spartan soldier's discourse would probably result in an undesired loss of spontaneity in the spectacular action scenes.

Why not, then, eliminate this discursive standpoint altogether and focus on the recreation of the actual event? By introducing a Spartan narrator, Snyder has highlighted the enormous ideological importance of this epic battle for the Greeks themselves, thereby showing how this otherwise small resistance of King Leonidas has inspired Sparta and many other citystates to organize a massive revolt against Xerxes. This approach may well

\footnotetext{
8 Nevertheless, the narrative approach slightly differs in the two media. See the appendix for a more systematic comparison and discussion.
} 
be justified, especially given the fact that Leonidas' rebellious behavior can be interpreted as a bold statement to the rest of Greece rather than an actual attempt to defeat the entire Persian army. ${ }^{9}$

But that is probably not the only reason why Snyder opted for this perspective. As the film demonstrates, the epic grandeur of the battle at Thermopylae can easily be molded into the style and conventions of the action movie, with grotesque visual effects and larger-than-life, hyper-masculine heroes. In most popular action movies like The Terminator (1984) and Robocop (1987), the directors very clearly rely on their audience's "suspension of disbelief," but since 300 stages an historical event, introducing a narrator may facilitate the audience's acceptance of the fantastic heroes, villains, and action scenes. In any case, the radical Spartan point of view, with its stress on toughness, combat, and athletic exercise, neatly fits the demands and expectations of modern aficionados of action movies.

\section{Gender and the Orient}

Of course, all this also has implications for the way in which masculinity and femininity as well as West and East are either praised or condemned in the film from the perspective of the male narrator Dilios, and via his intervention also through the eyes of the filmmakers. We first aim to analyze the phallogocentristic value scales according to which the narrator and the director offer their interpretation of the events at Thermopylae. In the next section, we will reflect on this value scale and investigate how an historical dimension might provide a proper response to the naturalizing processes of gender representation in 300 .

The Greek heroes of 300 are hyper-masculine super-warriors, needing nothing but a cape, a firm pair of underpants, a sword, and a shield. Their impressive muscles are their breastplates; their abdominals and quadricepses seem invulnerable to the Persian spears. During the entire film they heroically endure pain and grief, and they repress every "weak" emotion. Even when Leonidas sees his beloved wife for the last time, there is no sign of uncharacteristic melodrama:

9 Cf. Ernle Bradford, Thermopylae: The Battle for the West (New York: McGraw-Hill, 1980 ) 148: "The death of Leonidas and of his three hundred chosen men from Lacedaemon was seen at the time for what it was: a torch, not to light a funeral pyre, but to light the hitherto divided and irresolute Greek people." 
Goodbye, my love. He doesn't say it. There's no room for softness. Not in Sparta. No room for weakness. Only the hard and strong may call themselves Spartan. Only the hard. Only the strong.

The Spartans, as representatives of "real men," never give up, never abandon the battle field. Their heroism is directly linked to their courage and physical strength, prime examples of stereotypical male virtues.

The Persians are on the other side of the gender scale. They are associated with idle glamour, luxury, and Eastern exoticism. Very illustrative of this point is the harem scene during which the treacherous Ephialtes submits to Xerxes. The harem is constructed entirely of gold, and the women are extremely sensual and willing. ${ }^{10}$ Some deformed creatures, like the armless hermaphrodite and the woman with the disfigured face, are fairly indicative of a remarkable preference for decadent exclusiveness over conventional beauty. Xerxes' gentle words to Ephialtes seem quite appropriate - at least from a Persian perspective:

Everything you can ever desire. Every happiness you can imagine. Every pleasure your fellow Greeks and your false gods have denied you, I will grant you. For I am kind.

Of course, the narrator Dilios cannot have witnessed this harem himself, so this points even more directly to the propagandistic function of the scene. The grotesquely misshapen Spartan Ephialtes, rejected by Leonidas for his inability to serve in the army, is about to side with the Persians: the monster unites with the monstrous nation. Through the eyes of a Spartan soldier, all these decadent characteristics can only be interpreted as obvious signs of femininity, which is carried onto the battle field, where it is self-destructive.

On the visual level, the contrast between the Spartans and the Persians is underlined by their armor and physical appearance, even to the extent that the weaponry of the Spartan hoplites as we know it from historical sources has been exchanged here for a more idealizing image. The Spartans are presented in the Greco-Roman art concept of the "heroic nude."11

10 This is a stereotypical Orientalising perspective taken by Western men, who tend to be tantalized by the sensual, mysterious, submissive women that are associated with the east. Edward W. Said, Orientalism: Western Conceptions of the Orient (London: Penguin, 1995) 207: "women are usually the creatures of a male power-fantasy. They express unlimited sensuality, they are more or less stupid, and above all they are willing."

11 Cf. Christian J. Holoka, “3oo: History, Graphic Novel, Movie,” Michigan War Studies Review 3 (2007), accessed November 30, 2011, http://www.michiganwarstudiesreview .com/2007/20070504.asp. 
Ancient Greek heroes are commonly portrayed naked, wearing nothing more than a cloak and basic weaponry, which bestows upon them an air of divinity. This pose is an ode to the male human body. The Persians' armor, by contrast, marks their inferiority in comparison to the godly, manly, brave heroes of Sparta. Most of the Persian opponents wear light to moderately heavy costumes that allow them to move quickly on the battle field (albeit more often in retreat than in attack). Only the deformed gigantic Persian "Immortal," whose power exceeds even that of the Spartans, is depicted in clothing similar to Leonidas'. The former's brute force, however, is not able to cope with the latter's astuteness and swiftness, which adds considerably to the appreciation of Leonidas' supreme fighting skills.

The bipolarization of clothing styles is brought to a head in the confrontation between the two rulers. Leonidas is undeniably masculine: broad shoulders, heavy beard and moustache, and no other finery besides a wolf's tooth on a leather rope around his neck, a reference to his rite de passage. Xerxes, on the other hand, is a king with bling, wearing golden necklaces, rings, earrings and other piercings, useless fashion accessories, his head and body shaven, his nails polished, and his face plastered with make-up. David Meadows' description of Xerxes as "an over-sized drag queen" seems to be a rather justified translation to our modern standards. ${ }^{2}$ The Persian god-king, unarmed as he is, is obviously not able to fight or even directly command his own army. Whereas Leonidas commands his battling troops himself and fights along with them, Xerxes remains at a distance, inspecting the battlefield from his throne or from a high rock, far from any danger. Comparative scenes like these suggest that the real combat should be left over to real men without decadent refinement, not to a bunch of transvestites loaded with jewelry.

In sharp contrast to Xerxes, who, despite his sex, does not "perform" a masculine image, Queen Gorgo of Sparta does pursue her own honor by taking action, just like her male fellow-citizens. ${ }^{13}$ Already from the beginning of the story, her role as a powerful and respected Spartan woman is well-established, albeit predominantly through her procreating abilities:

12 David Meadows, “3oo and Iran," Rogueclassicism, March 17, 2007, accessed November 30, 2011, http://atrium-media.com/rogueclassicism/Posts/oooo5655.html.

13 The story line about the events in Sparta and, consequently, the character of Gorgo does not occur in Miller's graphic novel, and are therefore entirely new additions by the scenarists of the film. 
Persian messenger: "What makes this woman think she can speak among men?"

Gorgo: "Because only Spartan women give birth to real men."

The brief eye contact between Leonidas and his wife before he decides to kill the Persian messenger indicates Gorgo's influence on her husband, which suggests that both consider each other as equals. This is confirmed by the erotic scene in which Leonidas and Gorgo seem to have an equal amount of initiative and pleasure. Moreover, Leonidas is not afraid to show his respect for Spartan women in front of his opponent. In his encounter with Xerxes, Leonidas jokingly alludes to the Spartan women's courage and strength, especially in opposition to the Persian enemies:

Xerxes: Consider the fate of your women.

Leonidas: Clearly you don't know our women. I might have marched them up here, judging by what I've seen.

As appears already from the above discussion, Spartan women (and above all Queen Gorgo) can also excel within the framework of Dilios's discourse, but merely by behaving in a brave, essentially masculine way. Gorgo's fierce support of a just war is strikingly opposed by the treacherous conduct of the Spartan politicians, of whom Theron appears to be the prime example. Theron, the leader of the Spartan council, is depicted as a somewhat pathetic character, constantly trying to affirm and reinforce his own masculinity. Nevertheless, his efforts are deconstructed by the story-telling, and even by his own words and deeds. It appears that whoever is collaborating with the Persians is infected by unmanly conduct and cowardess.

A good example of this perversion of "traditional" gender roles is the scene in which Gorgo tries to persuade Theron to support her proposition to send the army to Leonidas:

Gorgo: I need your help in winning votes to send the army north to our king.

Theron: Yes, I can see the two of us standing together, me politician, you warrior. Our voices as one.

Theron calls Gorgo a warrior, in contrast to his own practices as a politician. The latter's exemplary activeness in demand of speedy deeds is in sharp contrast to the former's passive inclination to bureaucracy.

Later in the scene, however, Theron does try to reinstate the traditional order by pointing to the fact that Gorgo is a woman, whereas politics is a matter for men. 
Don't think that you, a woman, even a queen, can walk into the council chamber and sway the minds of men. I own that chamber, as if it was built with these hands.

However, when Gorgo decides to offer herself to Theron, the latter is apparently willing to drop this concern altogether. The moment before the actual abuse, when Theron turns Gorgo around and pushes her against the wall, he displays the politician's pathetic attempt to prove his own masculine dominance, but the fact that he had already given in to Gorgo's proposal proves his inherent mental and moral weakness.

In this respect, the rape that follows the conversation does not reestablish the traditional gender pattern, for neither does it place Gorgo in the passive feminine position nor Theron in the active masculine role. In fact, according to the way in which this scene is portrayed and its function in the wider narrative, it does not seem to be conceived as a forced rape at all. Gorgo deliberately chooses to offer her body to Theron in a strategic attempt to win him over for her cause. She takes off her clothes herself while retaining a determined look on her face. During the "rape" itself, the camera constantly focuses on Gorgo, zooming in on her facial expression, which exudes the queen's remarkable endurance and willingness to sacrifice herself for the sake of Sparta and Leonidas, as she had already confirmed earlier in the scene:

Theron: Do you love your Sparta?

Gorgo: Yes!

Theron: And your king?

Gorgo: I do!

From the male discursive standpoint which colors the characters' depiction, this scene seems to bestow on Gorgo a certain heroism, but not for her traditional feminine virtues but for her performance of the characteristic toughness which is also continuously on display in the actions of Leonidas and his three hundred brave men.

After this scene, Gorgo is allowed to speak in front of the council. The beginning of her speech is rather conventional, and points to her right to represent a standpoint that often cannot be heard:

Councilmen, I stand before you not only as a queen. I come to you as a mother. I come to you as a wife. I come to you as a Spartan woman. I come to you with great humility.... I am here for all these voices that cannot be heard: mothers, daughters, fathers, sons. 300 families that bleed for the very principles this room is built upon. 
After this traditional opening, we might expect Gorgo to continue this feminine discourse and beg the councilmen to make peace with the enemy and spare the lives of the men of the city. There is nothing of that in Gorgo's words, however, as she proceeds in an almost Churchillian fashion:

We're at war, gentlemen. We must send the entire Spartan army to aid our king in the preservation of not just ourselves but of our children.

Yet again, the gender roles are perverted. A woman comes to tell the councilmen to undertake action and fight for the defense of Greece. However, when Theron sees that Gorgo's speech seems to have an effect on the council, he launches a verbal ad hominem attack:

She's a trickster in true form. Do not play games with the members of this sacred chamber, my queen. Just hours ago you offered yourself to me. Were I a weaker man, I would have her scent on me still.

There is a twofold irony in Theron's words. First, he is the true trickster, since he gave his word to the queen and now breaks it in serving his own agenda. Second, he did fall for Gorgo's charms, so the weakness of which he supposedly accuses himself does actually pertain to him. Well knowing the appropriate behavior of an honorable Spartan man, Theron proves himself a despicable deviation.

Theron continues to insult Gorgo by calling her a "whore queen," after which Gorgo tries to hit the politician, but her attempt is blocked by the guards. Gorgo's first emotional response to Theron's personal insults is thus aborted. Nevertheless, when Theron explicitly points to her "inglorious behavior," Gorgo launches a more deliberate attack, acting as if she is willing to leave the council, but then grabbing a guard's sword and stabbing it in Theron's stomach.

Gorgo's assault is a clear inversion of the rape about which we spoke earlier. This time, however, the murder/rape is a brutal and - in the eyes of the storyteller - justified revenge. Gorgo stresses the parallelism between both scenes by using the exact same phrase as Theron during the previous rape scene:

This will not be over quickly. You will not enjoy this. I am not your queen.

However, the importance of this scene seems to extend far beyond Gorgo's personal revenge, for its political relevance is enormous. After the murder, when Persian golden coins fall out of Theron's pocket, the treason is finally revealed, which paves the way for the masculine discourse of war 
to win over the hearts of the councilmen. Gorgo thus appears to be one of the main saviors of the Greek and Spartan cause.

More generally, we may state that, in 300 , gender issues and orientalism are intertwined with one another, as they are both part of a wider propagandistic network. Masculinity and femininity are cut loose from the actual sex of the persons performing it. On the one hand, the male Persian army and Xerxes himself are ridiculed for their performance of effeminacy, just like their Spartan collaborators. On the other hand, we do find reverence and respect for women in 300 , but not for their femininity. Gorgo achieves her own honor and glory by taking action, speaking in front of the council, and carrying out a heroic masculine discourse.

\section{The Reception of/in 300}

In conclusion to this paper, we readdress the specific character of the story-telling in 300 and the negative criticisms it appears to have elicited. Snyder's narration of the battle in Thermopylae lifts this event out of the field of history into the realm of mythology. Indeed, when considered from the consideration of genre, 300 bears closer resemblance to the fantastic mythological movies and series around heroes like Hercules than to historical television documentaries that purport to portray an event just as it "really" happened. The genre of these mythological movies calls for its own particular characteristics and stereotypes. 300 has modeled its gender image after these demands by highlighting the omnipresence of a hypermasculine perspective and by almost exclusively valuing typically male virtues.

Nevertheless, 300 is more than just an artistic exercise in mythography. It also offers a piece of historical truth, albeit not a factual truth, but a truth of mentality history, as described by Foucault: ${ }^{14}$

a truth that is the order of discourse - a truth that makes it possible to employ, when dealing with the nature or history of knowledge, a language that will be true.

14 Michel Foucault, The Order of Things: An Archaeology of the Human Sciences (London: Tavistock Publications, 1970) 320. Cf. also Jacques Derrida, Of Grammatology (trans. Gayatri C. Spivak; Baltimore and London: The Johns Hopkins University Press, 1976) 10: "History and knowledge, istoria and epistémè have always been determined (and not only etymologically or philosophically) as detours for the purpose of the reappropriation of the present." 
The closing scene of the movie, where the Greek troops are assembled in Plataea, clearly demonstrates how not only real events matter, but also the way in which they settle themselves through cultural and discursive mediation in the collective memory, where they acquire the power to influence people's beliefs and behavior. It is only through this recognition that one can begin to understand the significance of Leonidas' sacrifice.

Against this backdrop, Zack Snyder provides a rarely formulated view of the Greeks and Hellenism. Although Hellenism is far from an uncontested and apolitical cultural domain, ${ }^{15}$ we may well wonder - and the negative criticisms of 300 seem to justify this assumption - whether presently most people do not feel inclined to accept a normative image of the Greeks, praising their artistic achievements and moral virtues. Snyder shows us a different type of reception. His Greeks - Spartans, and for once not Athenians - are not necessarily illuminative forbearers of Western civilization but historical people with their own assumptions, stereotypes, discourses, and values, which they most characteristically defined in opposition to the barbaric other. ${ }^{16}$ This contrastive self-conception results in antagonisms which are not only typical of war discourse but also of the historical definition of Greekness.

These perspectives compel us to realize that the worldview in the film is not immediately transmittable from the Spartans to ourselves - this perhaps in contrast to the impression generated by some other Hollywood blockbusters situated in the ancient world. ${ }^{17}$ The real dialogue between Greek and modern culture can start only from the acknowledgment of the other's otherness. The depiction of femininity and the Orient in 300 is not the dead end of this dialogue but merely stands at its cradle.

15 For an analysis of significant moments in the cultural history of Hellenism, see Simon Goldhill, Who Needs Greek? Contests in the Cultural History of Hellenism (New York: Cambridge University Press, 2002).

16 Snyder says: "I say that ' 300 ' is a movie that is made from the Spartan perspective and not just the Spartan's perspective, the camera is with the Spartans, but it's also the sort of Spartan sensibility of the battle of Thermopolis [sic]. If you had a Spartan and they were sitting around a fire and they were telling you, before anything was written down, what happened at Thermopolis this is the way that they would tell it, down to the fact that they don't have armor on. Everything about it is just to make the Spartans more heroic." "Interview with Zack Snyder," accessed November 30, 2011, http://www.latinoreview.com/ news/interview-zack-snyder-on-300-1558.

17 Cf. Joanna Paul, "Working With Film: Theories and Methodologies," in Lorna Hardwick and Christopher Stray, eds., A Companion to Classical Receptions (Oxford: Blackwell, 2008) 312: "[T]he raison d'être of some ancient world films seems to be to try and make us forget the gulf between ancient and modern, using all the cinematic weaponry of realism and naturalism to give the impression that the cinema screen provides a window on the ancient world." 
The critics' various objections to the film's viewpoints are therefore also a step in the direction of our own cultural self-definition. But, one may ask, should the fact that in 300 the dramatic action takes place in ancient Greece render the gender perspective any more problematic than in many non-historical action movies with equally hyper-masculine value scales? It is quite paradoxical that of all action movies, only a few have raised more criticisms about its worldview than 300 , which is nevertheless situated in a culture of a remote past. In this respect, the negative comments about 300 might have more to do with our own assumptions concerning the ancient Greeks than with the way in which their discourses are vividly performed on screen. If we are willing to view 300 as the staging of historically defined discourse, we might achieve a more refined dialogue between the discourses of our own culture and that of the ancient past, which creates a framework to question the self-evident air with which male gender construction is presented to modern audiences.

This leaves us with the conclusion that 300 offers a fairly peculiar reception of a battle which is generally regarded as a crucial event in the history of Western civilization. Instead of vituperating every moment when the Spartan view point does not coincide with our own, one can also focus on the "odd discourses" of the Greeks as a starting point for reflecting upon the world in which we now live. From such a perspective, perhaps 300 's greatest merits are its versatile mingling of ancient heroism and modern action drama, and its availing us of the opportunity to experience an insider's perspective into the Spartan way of thinking and speaking, which in turn allows for a cultural interaction between the world as it was, the world as it is, and the world as it should be. ${ }^{18}$

\section{Appendix: The Narrative Approaches in the Graphic Novel and the Film}

A comparison between the narrative approach of the graphic novel and that of the film might illuminate the typical features of the two media. Both approaches entail their own narrative difficulties, but in both cases, the narratological and logical incoherence does not obstruct a sound

18 Cf. William W. Batstone, "Provocation: The Point of Reception Theory," in Charles Martindale and Richard F. Thomas, eds., Classics and the Uses of Reception (Oxford: WileyBlackwell, 2006) 19: "This is the point of reception: where words, not my words, not your words, intersected with the past (memory, tradition, even individual history, and, of course, the unconscious) and the future (desire, chance, and ideology) are repeated in the future perfect of the present." 
interpretation of the book or film. Zack Snyder as well as Frank Miller use the specific character of their medium to their advantage in concealing the problematic status of their narrator.

As we have seen, the film version of 300 introduces only one main narrator, Dilios, whose story forms the basis for the entire depiction of the events. We have also already pointed out the fact that much of what Dilios says is not an eye-witness report but the product of the latter's propagandistic fantasy. However, since the external focalization of the camera gives the visual impression of objectively registering the true events, most of Dilios' inventions are likely to be interpreted by the audience as if they really happened. Moreover, when the viewers hear a voice-over commentary in the beginning of the movie and in other scenes as well, they are likely to associate this with an authoritative narrator, according to the conventions of the medium of film. Furthermore, Dilios qua narrator is only very scarcely shown to interfere with the action. All this conceals the latter's subjective involvement in the narration, even to the extent that many critics appear to take no notice of his presence. Thus, the narratological perspective adds for an attentive viewer a specific Spartan value scale, without, however, compromising the entertainment degree and the directness of the visual presentation.

In Frank Miller's graphic novel, the narrator is also a Spartan soldier, but not Dilios. The character Dilios is mentioned a certain number of times as a great story-teller, but the general perspective of the graphic novel is not his. Dilios' stories are always introduced by the main narrator, e.g.:

Dilios spins his stories. The story of Marathon. A perfect choice.

This implies that the narrator is an eye-witness of most of the events. His words are mere comments about what actually happened. Indeed, we do find a less extravagant depiction of the Persian troops in the graphic novel than in the movie. Except for the grotesque Persian attack with the elephants, the visual representation of the battle seems to stand closer to a credible picture of the war in Thermopylae (although there are still additions of epic grandeur from Miller himself).

The great advantage of adopting this narratological perspective for Miller's graphic novel is that Leonidas' death is narrated by a Spartan soldier who was actually there. Instead of isolating the narrator from the group of brave soldiers who died in Thermopylae, Miller stays with the action until Leonidas' final breath.

However, the strength of this approach is at the same time its weakness. The focus on the action through the eyes of a dying Spartan renders 
the crucial closing scene quite problematic. Since Dilios, the only survivor, is not the main narrator of the action, we encounter on the last two pages of the graphic novel, where the action is transposed to the battlefield in Plataea, a narrator who cannot but be already dead:

Captain Dilios spins his stories. His best story. The one about the Hot Gates. The Hot Gates - and beyond.

In the ultimate frame, however, this problem is fairly elegantly resolved. The narrator's final comment appears to be made from the standpoint of the entire Spartan army:

The order is given. The battle flutes play. To victory ... we charge.

The logical problem that the narrator can never have taken part both in the battle of Thermopylae and at Plataea is thus no insurmountable obstacle for the reader to enjoy this short closing scene as a part of the broader story-telling. However, the film scenarists could not rely on the same narrative trick, as the narrator in the film must necessarily have a certain voice and cannot at once represent the entire Spartan army. Therefore, despite entailing some problems of credibility, the change of perspective from an anonymous Spartan to Dilios seems the most obvious solution.

\section{Works Cited}

Bal, Mieke. Narratology: Introduction to the Theory of Narrative (2nd ed.; Toronto: University of Toronto Press, 1997).

Batstone, William W. "Provocation: The Point of Reception Theory," in Charles Martindale and Richard F. Thomas, eds., Classics and the Uses of Reception (Oxford: Wiley-Blackwell, 2006) 14-20.

Bradford, Ernle. Thermopylae: The Battle for the West (New York: McGraw-Hill, 1980).

Butler, Judith. Gender Trouble (7th ed.; New York and London, Routledge, 2010).

Corliss, Richard. "7 Reasons Why 300 Is a Huge Hit," Time, March 14, 2007, accessed November 30, 2011, http://www.time.com/time/arts/article/o,8599,1598977,00.html.

Derrida, Jacques. Of Grammatology (trans. Gayatri C. Spivak; Baltimore and London: The Johns Hopkins University Press, 1976).

Foucault, Michel. The Order of Things: An Archaeology of the Human Sciences (London: Tavistock Publications, 1970).

Genette, Gérard. Narrative Discourse Revisited (trans. Jane E. Lewin; Ithaca, N.Y.: Cornell University Press, 1990).

Goldhill, Simon. Who Needs Greek? Contests in the Cultural History of Hellenism (New York: Cambridge University Press, 2002).

Holoka, Christian J. “3oo: History, Graphic Novel, Movie,” Michigan War Studies Review 3 (2007), accessed November 30, 2011, http://www.michiganwarstudiesreview.com/2007/ 20070504.asp. 
Meadows, David. "30o and Iran," Rogueclassicism, March 17, 2007, accessed November 30, 2011, http://atrium-media.com/rogueclassicism/Posts/00005655.html.

Miller, Frank and Lynn Varley. 300 (Milwaukie, OR: Dark Horse Comics, 1998).

Moore, Roger. "300 As Facist Art," Orlando Sentinel Entertainment/Movies Blog, March 7, 2007, accessed November 30, 2011, http://blogs.orlandosentinel.com/entertainment_ movies_blog/2007/03/300_as_fascist_html.

Paul, Joanna. "Working With Film: Theories and Methodologies," in Lorna Hardwick and Christopher Stray, eds., A Companion to Classical Receptions (Oxford: Blackwell, 2008) 303-314.

Peneaud, François and Joe Palmer. "Frank Miller and 30o's Assault on the Gay Past," AfterElton.com, March 5, 2007, http://www.afterelton.com/movies/2007/3/30o.html.

Pomeroy, Arthur. Then It Was Destroyed by the Volcano: The Ancient World in Film and on Television (London: Duckworth, 2008).

Said, Edward W. Orientalism: Western Conceptions of the Orient (London: Penguin, 1995).

Snyder, Zack. 300 (Warner Bros Pictures, 2006).

Verstraten, Peter. Handboek filmnarratologie (2nd ed.; Nijmegen: Vantilt, 2008). 


\title{
"EVERYBODY LOVES A MUSCLE BOI": HOMOS, HEROES, AND FOES IN POST-9/11 SPOOFS OF THE 300 SPARTANS
}

\author{
Ralph J. Poole
}

In 2007-2008, a significant accumulation of cinematic and other visual media focused upon the celebrated episode of Greek antiquity recounting in different genres and styles the stand of the three hundred Spartans against the Persians at Thermopylae. Among them are David Padrusch's documentary The Last Stand of the 300 (2007), Zack Snyder's feature film 300 (2006), Collision Studios' video game 300: March to Glory (2007), Andy Signore's short film United 300 (2007), and the Jason Friedberg/Aaron Seltzer comedy Meet the Spartans (2008).

Why did the legend of the three hundred Spartans seem so attractive for contemporary American visual media at that time? An anecdotal, yet telling account stems from the economic sector of society. Emerging at the dawn of the worldwide financial crisis, the fight of the three hundred Spartans served as point of reference for the serious loss of confidence in the banking system and also in national politics in general. William Streeter of the $A B A$ Banking Journal specifically wondered about what was keeping bankers up at night:1

What a fragile thing confidence is. Events of the past six months have seen it coalesce and evaporate several times... This is what keeps central bankers awake at night. But then that is their primary reason for being, because the workings of economies and, indeed, governments, hinge upon trust and confidence... With any group, whether it be 300 Spartans holding off a million Persians at Thermopylae or a group of central bankers trying to keep a global financial community from bolting, trust is a matter of individual decisions. But these decisions are often influenced by events, peers, crowds, or a persuasive strong leader. Such a leader can convince others the best chance for survival or success is in overcoming fear and having confidence that together they can overcome the onslaught. Or, as Ben Franklin put it to his fellow revolutionaries, "We must hang together, gentlemen ... else, we shall most assuredly hang separately."

1 William W. Streeter, "Confidence Needs to Be Led," ABA Banking Journal 100.1 (2008) 4, accessed June 4, 2010, http://www.nxtbook.com/nxtbooks/sb/ababjo108/index .php?startid $=4$. 
This assessment draws an image of bankers as the last bastions of hope and confidence, as revolutionaries and fighters to a man - a curiously ambiguous image of the global finance market. Are the financial decisionmakers carriers of hope or kamikaze fighters? If the bankers are the spearheads of a credible battle, who then is the enemy? "Confidence, like string, can't be pushed. It must be pulled - by actions" - Streeter's final statement of the article. Even though the reference to the 300 Spartans stresses bravery in a just cause, there remains the silent implication of the historical fact that all Spartans fell in this battle. In its historical precedent, the action - called for in the article and warranted by referring to Benjamin Franklin as reincarnated American revolutionary/Leonidas-figure - led to sure death. Certainly, the author wished no such fate for these bankers.

Though this financial scenario is not necessarily typical for the broad reception of the story of the three hundred Spartans in contemporary America, it nevertheless shows to what extent the turbulence of the present is imbued by the notion of ancient heroism, be it within economic, political, or cultural scripts. For the remainder of this essay I will concentrate on the latter of these by focusing on two such reinscriptions of antiquity in current filmic productions: the two spoofs Meet the Spartans and United 30o, with Zack Snyder's 300 serving as intertextual foil against which to assess the comic quality of the two parodies. To be sure, all three films are parodies, but of contesting partiality since only Meet the Spartans and United 300 push the parodic element to the point of excessive ridiculousness and can ultimately be read as political satires on the American "War on Terror" in the aftermath of $9 / 11$. These films are therefore instances of what Martin Winkler has called "the extremes of unabashed embraces of the lurid and the ridiculous" within the longstanding cinematic tradition of retelling ancient myths and archetypes that filmmakers have used "consciously in order to comment on their own times."

Accordingly, I wish to view these films as parodies not only in their formal style as aesthetic interpretations of previous texts, but also and above all in their pragmatic functionality, i.e., to address their respective ideological implications. As much as they can be called comic parodies, it has to be stressed that they apply a mimetic technique that according to Jonathan Culler implies "a serious statement of feelings about real prob-

2 Martin M. Winkler, ed., Classical Myth and Culture in the Cinema (Oxford: Oxford University Press, 2001) 3. 
lems or situations." ${ }^{3}$ The films' specific moment of transgression results from the tension between formal double-voicedness and political critique or, as Linda Hutcheon concedes: "Parody is a form of auto-referentiality, but that does not mean that it has no ideological implications." ${ }^{4}$ Indeed, these films, I claim, are both highly self-reflexive in their aesthetics of parody and highly ideological in their politics of insinuation.

Harking back to Greek antiquity is phantasmatic and mythologizing when the reliance on a legend like that of the 300 Spartans is used to assess a current sensibility. Significantly foreshortening the myth of Greece as cradle of Western civilization, this brings antiquity to the present in order to reenact fantasies of violence and male heroism without questioning the underlying ethos of homosocial fraternity. The parodic invective - and the rhetoric applied in Meet the Spartans and United 300 may be understood as such - opens up to an aesthetic and ideological minefield. Adapting the Greeks of former times to a universal "we" of our times here as in other cases of such referencing surely triggers the question: "it's Greek to whom?" Scott Bravmann has provocatively posed this question in his study on Queer Fictions of the Past: ${ }^{5}$

One important way of beginning to address this question is to consider alongside these metaphoric and literal 'returns' to Greece the use of new, or alternative, or resistant, 'national' discourses in the struggle over possible meanings for queer historical subjects.

Bravmann calls queer such subjects operating within imagined cultural geographies, when there occurs the contesting of a "false (or at least falsely universalizing) characterization of 'Greece' as a significant locus of cultural truth for us." Adding to this, I would also claim as queer textual strategy the spoofing performed in Meet the Spartans, where a historical allegory like 300 crudely gets counteracted and is turned into its grotesque-comic opposite. We should ultimately ask, therefore, in what ways these spoofs make fun of 3oo's reenactment of the belief in America's Manifest Destiny (see Solomon's essay) and the adjoining cult of Spartan heroism?

\footnotetext{
3 Jonathan Culler, Structuralist Poetics: Structuralism, Linguistics and the Study of Literature (London: Routledge \& Kegan Paul, 1975) 153.

4 Linda Hutcheon, A Theory of Parody: The Teachings of Twentieth-Century Art Forms (Urbana: University of Illinois Press, 2000) 28.

${ }^{5}$ Scott Bravmann, Queer Fictions of the Past: History, Culture, and Difference (Cambridge: Cambridge University Press, 1997) 61-62.
} 


\section{Herodotus and the Legend of Heroic Sacrificial Death}

The historical origin of all the aforementioned films is first and foremost the account of the Spartans' uprising led by Leonidas against the Persian slave empire of King Xerxes of $480 \mathrm{BC}$. Already Herodotus in his Histories, which serve as major source for this now legendary story, speaks of Spartan manly heroism as best exemplified in the mythicized scenario of the "last stand." This fight to a man in its later reception has either served to glorify heroic martyrdom as the epitome of the Spartan democratic ethos, or has led to acerbic criticism and deriding laughter of these exaggerated male virtues. And it is not only recent examples in the American context that have called upon this heroic sacrificial death for contemporary political purposes: Hermann Göring also referred to the battle of Thermopylae to legitimize the battle of Stalingrad in 1943 as a fight of "no surrender." 6

Writing a generation or so after the war, Herodotus relates the events of the battle of Thermopylae in the seventh book of his Histories. Even though the historical validity of Herodotus' accounts have been contested (on the one hand they are most detailed descriptions of historical events, on the other there is compelling evidence of fake "eyewitness" accounts), the fascination with his "history" remains unbroken. ${ }^{7}$ Books 7 to 9 are about the Persian Wars against Greece. Book 7 ends with this important battle which marks the advent of the Second Persian War as well as the death of Leonidas I, who reigned as King of Sparta from 490 to 480 BC. Other historians such as Diodorus, Justin, Pausanias, and Strabo have also referred to the celebrated battle, but it was Herodotus' text that served as the blueprint for the legend. Herodotus (7.175) claims that because of the news of Xerxes marching against Europe, the Greeks decided to guard the mountain pass of Thermopylae "and so stay the barbarian's passage into Hellas." While several Greek cities sent out troops, it was the Spartan army of Leonidas that is especially highlighted: ${ }^{8}$

6 Paul Cartledge, Thermopylae: The Battle That Changed the World (New York: Vintage, 2006) 192; see also Anuschka Albertz, Exemplarisches Heldentum: Die Rezeptionsgeschichte der Schlacht an den Thermopylen von der Antike bis zur Gegenwart (München: Oldenbourg, 2006) 293-308.

7 See Charles Hignett, Xerxes' Invasion of Greece (Oxford: Clarendon, 1963) 105-148; Ernle Bradford, The Year of Thermopylae (London: Macmillan, 1980); George J. Szemler, William J. Cherf, and John C. Kraft, Thermopylai: Myth and Reality in 480 B.C. (Chicago: Ares, 1996); Nic Fields, Thermopylae 480 BC: Last Stand of the 300 (Oxford: Osprey, 2007).

8 Herodotus Histories 7.204-205. 
Each city had its own general, but the one most admired and the leader of the whole army was a Lacedaemonian, Leonidas, [who] had gained the kingship at Sparta unexpectedly.... He now came to Thermopylae with the appointed three hundred he had selected, all of whom had sons.

The legendary army of the so-called Three Hundred was the king's bodyguard in case of war and it was supposed to be assured by selection ("all of whom had sons") that in case of death the continuance of Spartiate families would not be endangered. After partial victories of the Greeks, the final battle ended as known with the ultimate demise of the Spartan army. Three of Herodotus' related events are important for such later fictionalized adaptations as our films:

(1) (7.133): The killing of the Persian messenger, which Herodotus actually relates back not to Xerxes, but to his predecessor Darius: "To Athens and Sparta Xerxes sent no heralds to demand earth, and this he did for the following reason. When Darius had previously sent men with this same purpose, those who made the request were cast at the one city into the Pit and at the other into a well." All adaptations change this historical sequence, thus disregarding Xerxes' forebodings and dramatizing the messenger's violent death as one of the triggering moments of warfare instead.

(2) (7.213): The betrayal of a Greek renegade marks another instance taken up by our films: "The king was at a loss as to how to deal with the present difficulty. Ephialtes, son of Eurydemus, a Malian, thinking he would get a great reward from the king, came to speak with him and told him of the path leading over the mountain to Thermopylae. In so doing he caused the destruction of the Hellenes remaining there."

(3) (7.220): As a result, all but the Spartan troops retreated, which as Herodotus claims ensured Sparta's heroic superiority and its lasting, if tragic fame: "It is said that Leonidas himself sent them away because he was concerned that they would be killed, but felt it not fitting for himself and the Spartans to desert that post which they had come to defend at the beginning. I, however, tend to believe that when Leonidas perceived that the allies were dispirited and unwilling to run all risks with him, he told them to depart. For himself, however, it was not good to leave; if he remained, he would leave a name of great fame, and the prosperity of Sparta would not be blotted out."

The Persian messenger's death, Ephialtes' betrayal, and the heroic last stand are those motifs that are central for most of the ensuing adaptations and parodies. In what follows I am attempting a three-tiered reading of the film Meet the Spartans under varying guiding aspects, each holding differing generic/aesthetic, historical/political, and gendered/ethnic implications, respectively. First, the film serves as parody on familiar American popular culture unearthing traditionally gendered Hollywood clichés like 


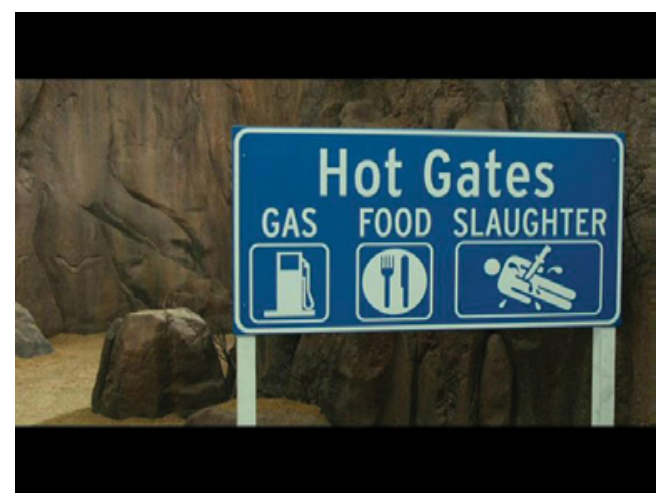

Figure 1

the myth of the male hero and its appending genre of the what we might label the Last-Stand film as spoof of reigning cults of masculinity. A second closer textual reading of Meet the Spartans reveals the film as parody of Zack Snyder's 3oo, where Leonidas is shown as a ritually steeled soldier willing to sacrifice his life as "free man"; in the spoof, Leonidas has turned into a lusty, yet incapable macho leader instead. Finally, a last section will bring the short film United 300 into the discussion of Spartan heroism as gross clownery.

Ribald Humor and Sandal Aesthetics: Meet the Spartans as Parody of American Popular Culture

The film Meet the Spartans is a co-production by Jason Friedberg and Aaron Seltzer. Their teamwork as writers and directors includes other parodic films like Scary Movie (200o), Date Movie (2006), and Disaster Movie (2008), but above all Epic Movie (2007) to which Meet the Spartans (2008) was first conceived as follow-up. In all these films, including Meet the Spartans, the Friedberg/Seltzer duo makes fun of common clichés of American film, television and popular culture (see Figure 1). But, in contrast to the other films, in Meet the Spartans they resort to the arsenal of antiquity to combine historical elements with thematic and aesthetic allusions to contemporary family comedies (e.g. Jay Roach's Meet the Parents (2000) and Meet the Fockers (2004), fantasy films like the Shrek-series, the James Bond-filmic style, the American Idol-talent show, and the American media star cult (Britney Spears, Paris Hilton, Angelina Jolie, Brad Pitt, Tom Cruise, Sylvester Stallone). While the film's fecal and ribald humor brought 
disastrous reviews (a considerable box office success not withstanding), one has to grant the film its successful over-the-top spoofing of precious and beloved gendered Hollywood clichés, especially when it comes to the cult of male heroism and the related heroic genre of the Last-Stand film with its variations of the sword-and-sandal film, the war melodrama, and the spaghetti Western. ${ }^{9}$ The genre of the historical epic in Meet the Spartans has been superimposed onto contemporary cinematic forms of popular male cinema leading to a parodic negotiation - and indeed clash - of reigning cults of masculinity.

In this sense, the parodic technique of Friedberg and Seltzer may be called "creative criticism" in Wes Gehring's terminology. ${ }^{10}$ This significant trademark of American parodic films in general relies on the fact, as Gehring claims that:

the genre often has been considered as something less than important; it has been defined as a parasitic growth on true works of art...

Especially Friedberg and Seltzer's favored use of wordplay, which in the guise of the joke is already a shortened form of parody, "may often seem the lowest form of literary art." ${ }^{11}$ Friedberg/Seltzer deliberately turn to this "trashy" tradition of American parody employing all registers of jokes in bad taste. In the course of his ritual initiation into manhood, for example, Leonidas (Sean Maguire) of Meet the Spartans has to undergo a form of torture that is taken right out of the James Bond film Casino Royale. In a clichéd manner, the torturer, clad in trendy black if blood-stained suit, tries to extract some bank account number from an utterly ignorant, loinclothed Leonidas, who is taken to be the famous secret agent. As in the prototypical Bond film, the perpetrator viciously assaults his victim, the difference being, of course, that while Leonidas writhes in great pain, he has no clue and thus no secret to hide, exclaiming in utter consternation: "Who the hell is Mr. Bond? I'm Leonidas!" For the spectator, the joke, which diegetically grounds on the misunderstanding of the two protagonists, arises predominantly on the level of the extradiegetic, namely, by

\footnotetext{
9 See Maggie Günsberg, "Heroic Bodies: The Culture of Masculinity in Peplums," in Italian Cinema: Gender and Genre (Houndsmill: Palgrave Macmillan, 2005) 97-132; Steve Neale, "War Films," Genre and Hollywood (London: Routledge, 2000) 125-133; Christopher Frayling, Spaghetti Westerns: Cowboys and Europeans from Karl May to Sergio Leone (London: Routledge, 1981).

10 Wes D. Gehring, Parody as Film Genre: Never Give a Saga an Even Break (Westport: Greenwood, 1999) 4.

11 Joe Lee Davis, "Criticism and Parody," Thought 26 (1951) 185; Gehring, Parody as Film Genre, 4.
} 
the clash of two starkly incongruent cultural epochs and filmic genres the high tech agent thriller and the historical epic. The male initiation, which Leonidas according to his cultural tradition is supposed to undergo, is void of any meaningful significance and turns into mere caricature of male power play.

This manner of comic contrast runs through the entire film and does not even stop short of the conjugal chamber. Here, the night before Leonidas leaves to fight his battle, he questions the prediction of the Oracle, who appears in the guise of the leading heroine from the American television series Ugly Betty. The ensuing dialogue again mixes thematic issues (the tragic hero's serious doubts) with comic bedroom farce (the husband lacking sexual prowess while his emasculating, sexy wife shows much more cleverness) and pop-cultural reference (The Oprah Winfrey Show). Thus Leonidas' wife Margo (Carmen Electra) responds to Leonidas' request for advice:

Margo: There's only one woman whose words you should listen to.

Leonidas (nodding in assent): Oprah.

Margo: Your wife!

The broad array of spoofed objects transcends all restriction of space and time. The Greek setting remains the outer framework from which the plot evolves, but the many contemporary references all stem from a different historical time and a different cultural and geographical space, namely current American popular culture and politics. While Leonidas has to survive in the wilderness as part of his initiation as warrior, for example, he is miraculously provided with a sandwich from the fast food-chain Subway, which he finds too appalling to eat even though on the verge of starving. And deciding whether one of the sons is allowed to join his father in the battle force (historically inaccurate because he is the only son and therefore prohibited to go to war according to Spartan law), the jury of a beauty pageant, spoofing the talent show America's Next Model, crowns him as "Sparta's Next Top Model," effectively allowing him to enter war and thus overturning Spartan law and turning him into a veritable pin up-boy warrior (see illustration).

The film here as elsewhere exceeds the generic borders of parody in a strict sense. According to Gehring: ${ }^{12}$

12 Gehring, Parody as Film Genre, 10. 


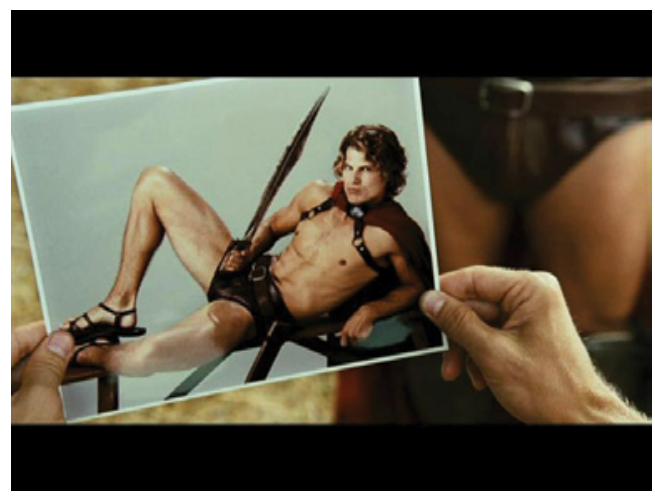

Figure 2

Parody ... is based on triggering a viewer's prior knowledge of a given genre or auteur, it is [therefore] important to showcase early on (through icons) which particular subject has been nominated for the user-friendly hot spot. Again, this accents the point that parody focuses on having fun with a given structure or text.

Undoubtedly, the film relies on the spectators' specific filmic and/or historical knowledge, but the main parodic aim is not only the spoofing of historical events and their filmic representations. The films does that, too, as I will show shortly. Rather, my point here is that the film uses the backdrop of antiquity to make fun and indeed to criticize phenomena derived from diverse backgrounds and sources and as such is a "compound parody," i.e., an eclectic mixture of various genres and subjects being parodied. ${ }^{13}$ For that reason, I want to highlight two scenes, which figure prominently in the filmic versions: the killing of the Persian messenger and the Last-Stand battle scene.

In 300 , the Persian messenger who in the name of Xerxes demands Sparta's submission gets thrown into the pit together with his entourage leading to the assault of the Persian army. In Meet the Spartans, the messenger (rapper Method Man) is kicked into the pit as well. But the pit in the course of the film serves as waste dump for all kinds of other disposable subjects: various pop stars such as Britney Spears and the whole team of the talent show American Idol are put on trial and chucked into the pit as cultural garbage. Politicians such as George W. Bush face the same ordeal (see Figure 2). Actors mime those film, television, and political icons 


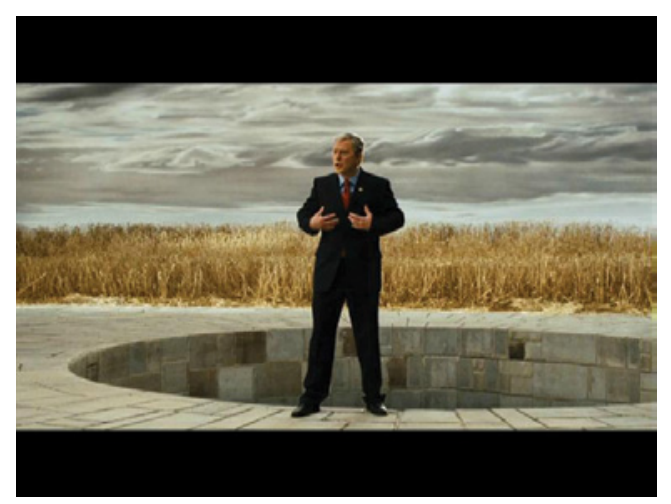

Figure 3

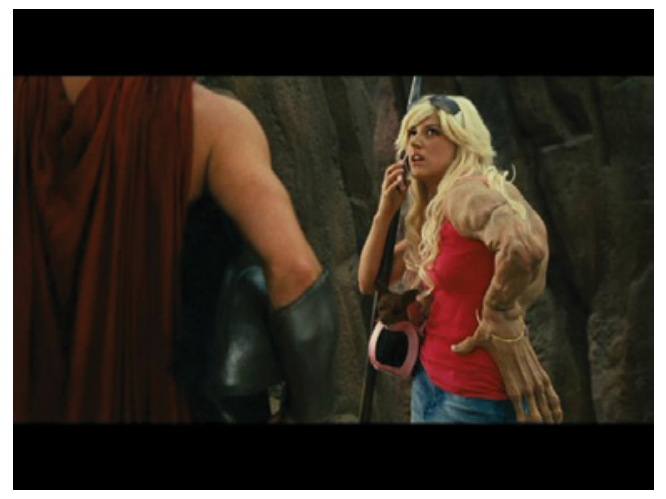

Figure 4

and in doing so vary a parodic technique that employs unknown actors instead of genre icons making benign fun of themselves through cameo appearances. Meet the Spartans, however, is a far cry from such a "friendly attack."14 The legendary betrayal of the Spartans by a Greek renegade, for instance, here features a hunchbacked Britney Spears impersonator (see Figures $3 \& 4$ ). The imitations are not only deliberately badly impersonated; the imitators or rather the referenced "icons" being imitated also serve as satirical butt of many acerbic jokes.

14 Ibid., 9 . 


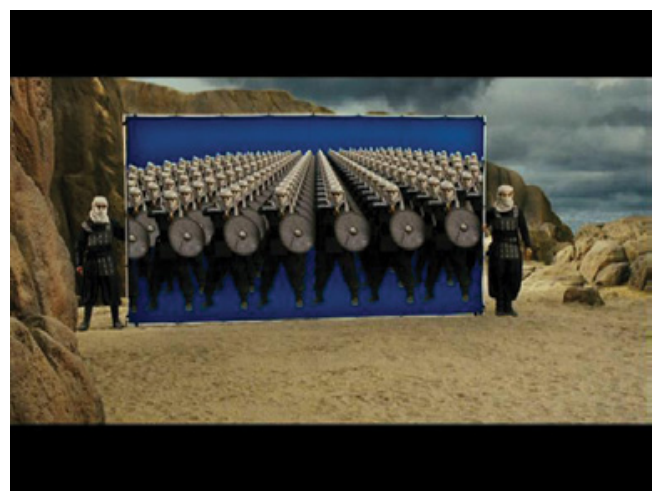

Figure 5

This parodic strategy is even further heightened through diverse autoreferential allusions. In the bedroom-scene mentioned above, for example, Queen Margo quotes a review of the film we are watching at the moment: "Harry Knowles at Ain't It Cool News says this film is just a cheap rip-off of $300 . "$ This makes fun of the film's generic "bad" style by performing this very style at the same time. Similarly, the battle scenes in Meet the Spartans are played out as comment on the constructedness of the film. The respective scenes in 300 were filmed in a complicated bluescreen technique, i.e., studio footage filmed in front of a bluescreen being filled up with visual effects in post-production. Meet the Spartans picks up this technique as diegetic motif and installs it as a strategy to be discussed and laughed at within the film. Gehring comments on this self-reflexive parodic method, claiming that ${ }^{15}$

Such movie self-consciousness represents the ultimate parody prick, since nothing affectionately deflates a celebrated genre or auteur faster than a comic reminder that this is, indeed, "only movie."

Accordingly, when the Persian army appears on the battlefield literally, they carry bluescreens on which they multiply troops by switching on the screen animation like a light bulb (see Figure 5). This satirizes the heroism of the warriors as much as it comically exposes and subverts the spectacular film technique of its pretext. 


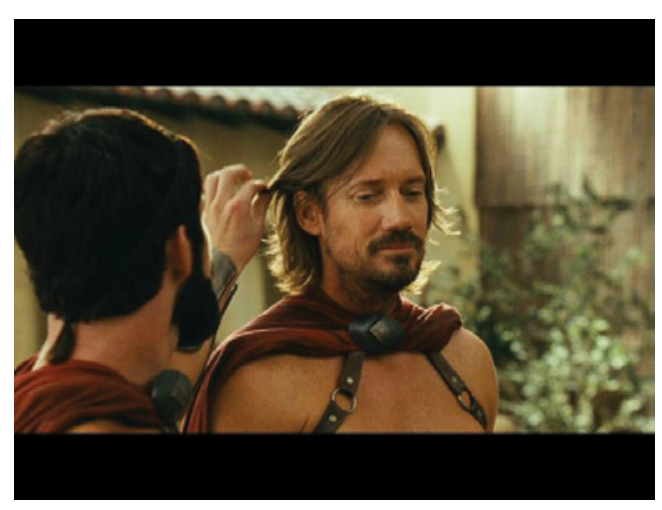

Figure 6

\section{Homo-Macho and Disco King: Meet the Spartans as Parody on the Spartan Three Hundred}

Herodotus 7.208-209: [Xerxes' scout] saw some of the men exercising naked and others combing their hair. He marveled at the sight and took note of their numbers... When Xerxes heard that, he could not comprehend the fact that the Lacedaemonians were actually, to the best of their ability, preparing to kill or be killed. What they did appeared laughable to him (see Figure 6).

Meet the Spartans is, in a strict parodic sense, a spoof of Snyder's 300. But this opens an even wider-reaching network of intertextual and intercultural cross-references. Not only does Snyder's film depend heavily on the graphic novel by Frank Miller (1998), which accounts for the stylistic mix of monumental epic and animation film of both ensuing movies. 300 furthermore refers to Rudolph Maté's The 300 Spartans (1962), which in turn needs to be seen within the cultural context of the Cold War forging a trace of political dichotomization that runs through all later works in their respective depiction of ethnic and national otherness. Each of these works narrates the legend of the Spartan uprising of 480 BC led by Leonidas against Xerxes' Persian slave empire. In 300 (both graphic novel and film), Leonidas is represented as heroic soldier, steeled by manly initiation, who with his three hundred selected Spartans is willing to fight to the last remaining man and who, while being deceived and betrayed, nevertheless dies as "free man" on the battlefield of Thermopylae. In contrast, Leonidas of Meet the Spartans, is denigrated as lusty, yet hardly heroic macho with only a scraggly troop of thirteen morons (see Figure 7 ). 


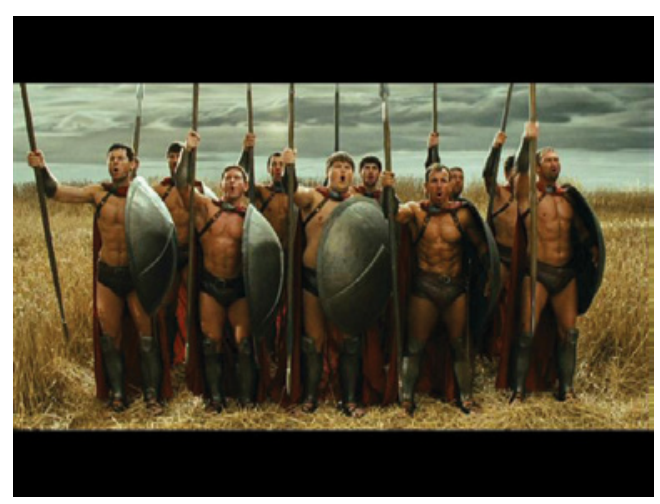

Figure 7

Leonidas' deconstructed manliness on the one hand psychologically undermines the myth of the last Spartan as being brave and stalwart. The substitution of soldiers putting up a manly fight with dance contests, game shows, and bluescreen animation, on the other hand, medially satirizes the mythic setting. Together with his soldiers, Leonidas dances and sings throughout the war scenario, and the Spartan warriors excel not as diehard fighters but as homophilic queens supervised by a ruler, who in his last night with his wife had to take a severe and literally castrating blow as potent lover. In that conjugal scene, Leonidas' heterosexual masculinity is put under scrutiny by female Spartan witnesses, who laugh at Leonidas as "Ken doll" pointing to the obvious lack of a (functioning) male sexual organ (see Figure 8). In a wider sense, this also serves as reference to the cinematic cult of muscles, thus shifting the focus from the hero's male chest in the traditional sandal epic to his genitals: ${ }^{16}$

For films with so many scantily clad men, however, there is no sense of genitalia - that is, the viewer's eye is drawn again and again to the same feature of Hercules, and it is not his bulging crotch; it is his chest.

In Meet the Spartans, there is plenty of crotch to pay attention to, albeit most phallic insinuations are meant in a ridiculing manner suggesting a dysfunctional heterosexuality.

Instead, Leonidas and his soldiers fondle, hug, and kiss each other, clearly enjoying their comrades' physical closeness (see Figure 9).

16 Robert A. Rushing, "Gentlemen Prefer Hercules: Desire / Identification / Beefcake," Camera Obscura 69.3 (2008) 180. 


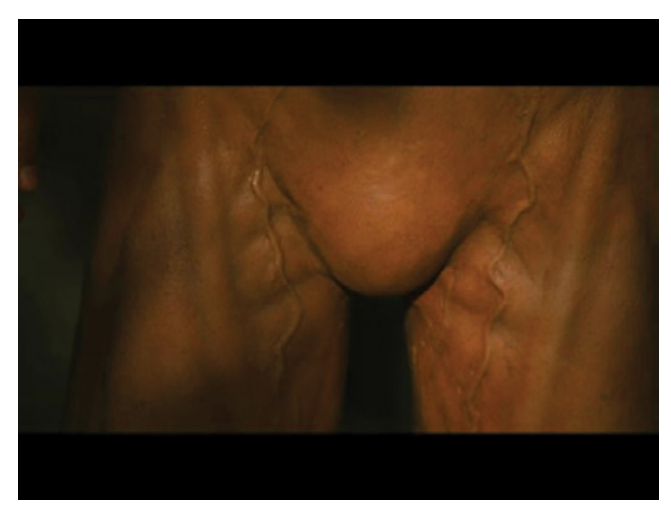

Figure 8

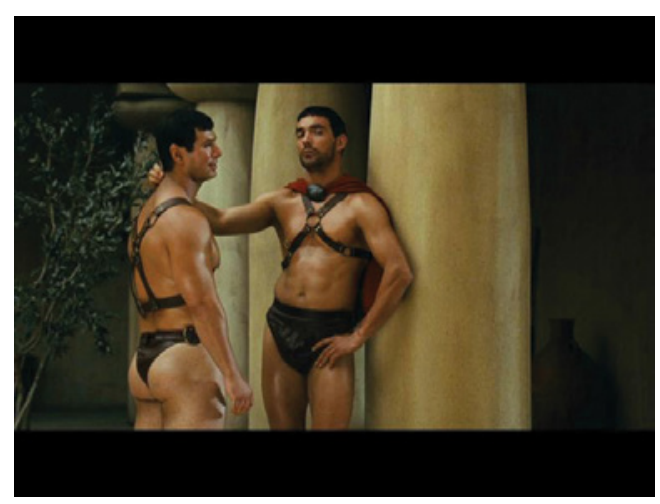

Figure 9

Holding hands, they pair up to march to war singing Gloria Gaynor's gay anthem "I Will Survive" (see Figure 10).

This gay cliché notwithstanding, the Spartans make fun of the "faggy" Persians. The film, however, does not grant Xerxes and his army a great deal of narrative and visual space, and thus prevents any rash conclusions as to their sexual predilections. The focus remains rather on the Spartans and their interactions with one another as well as the Persian enemies. In contrast to Zack Snyder's representation of Xerxes (Rodrigo Santoro) as highly fetishized and sexually androgynous god-king, Xerxes (Ken Davitian) of Meet the Spartans has all the same fetishistic paraphernalia, but is denigrated as a fat, old, and thus desexualized caricature (see Figures $11 \& 12$ ). 


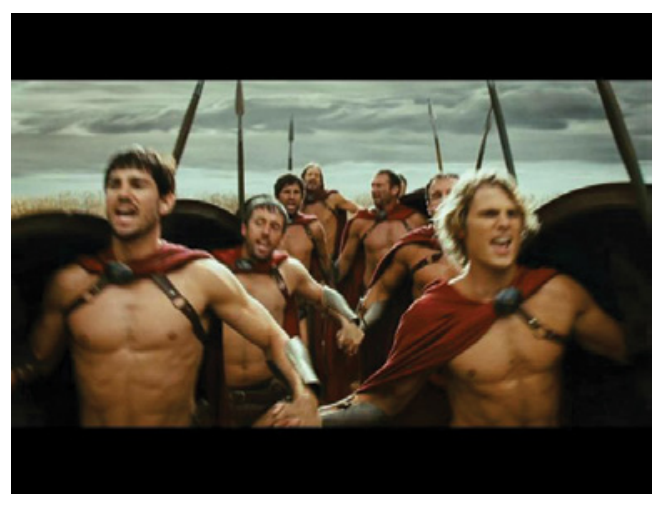

Figure 10

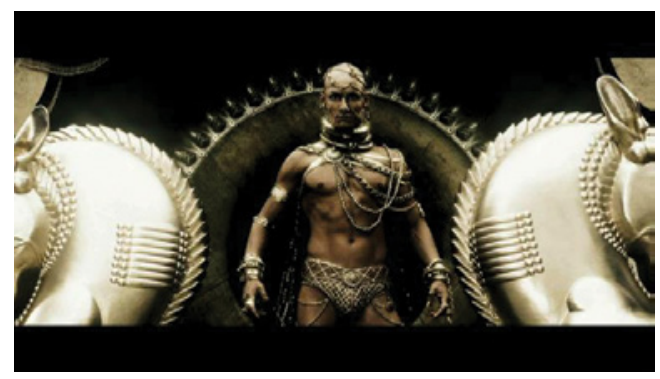

Figure 11

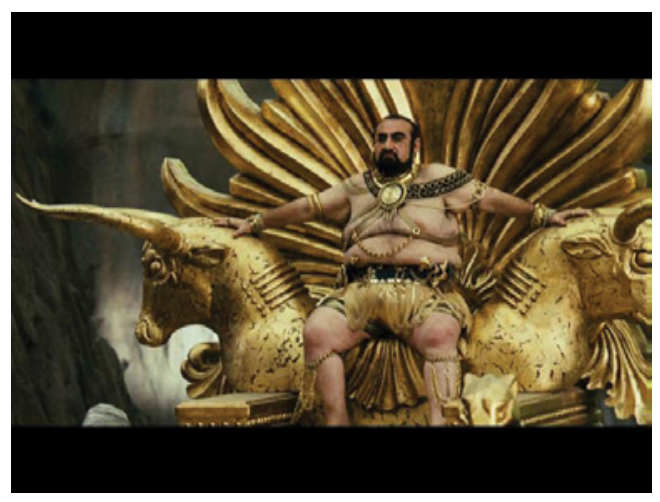

Figure 12 
The explicit allusion to the mockumentary Borat, where Davitian played Borat's quarrelsome fellow countryman, Meet the Spartans turns Xerxes into a comically grotesque power figure. This filmic rereading of the Xerxes figure marks an essential parodic strategy, because one iconic representation of masculinity - the androgynous Oriental - is substituted by another - the grotesque comedian. And only the first of these representations can serve as a paradigm of homosexualizing the image of the foe. This stereotyping has been noted by several critics, one of whom comments on Rodrigo Santoro's appearance in $300::^{17}$

King Xerxes who's dolled up with enough glittering threads and glossy makeup to make every David Bowie wanna-be from the mid-1970s chew his knuckles in fuming envy.

The numerous allusions to the homosexuality of the Spartans (and not of the Persians) in Meet the Spartans indicates a significant parodic turn that points towards the hiatus of a doubled historiography wherein ancient Greece is described as the founding model of Western civilization, on the one hand, and called upon as the grounding myth for the contemporary gay liberation, on the other. Whereas 300 applies homosexuality above all as habitual practice for the ethnically and culturally othered Persians (personified by Xerxes) and denies it for the Greeks, Meet the Spartans contrastingly installs the homosexual practice of the Greek antiquity for the Spartans, queering it comically, however. This queering needs to be stressed, precisely because it exposes the peculiar gap in 300: ancient Greek homophilia. Paul Cartledge asserts the consistent fascination with the social practices of the Spartans, including their institutionalized pederasty between a young warrior and an adolescent boy, as part of a stateordained pedagogical system. ${ }^{18}$ The Spartans practiced this educational method based on physical training (agoge) as an integral part of a young man's ceremonial masculinization: ${ }^{19}$

Sharing in a lopsided partnership of this nature had for the junior party the force of an initiatory ritual, an essential step along the gruelling road to his achieving full manhood.

17 Gene Seymour. “On the Field of This Battle, War is Swell.” Newsday, March 9, 2007, accessed December 2, 2009, http://www.allbusiness.com/humanities-social-science/ history/11900802-1.html.

18 Cartledge, Thermopylae, 208.

19 Ibid., 70. 
Not only does 300 eclipse the sexual part of the depicted practice of physical initiation, Leonidas also explicitly and disrespectfully comments on the other Greeks, especially the Athenians, as "philosophers and boy-lovers." He distinguishes them from the martially potent - and implicitly "womenloving" - Spartans and therefore falsifies a particular but essential aspect of Spartan cultural history.

Meet the Spartans twists the doubly denounced gender politics of 300 (androgynous Persians and pederast Athenians) into an affirmation of the Spartans as being full-fledged queer. It is not the other Greeks or foreign Persians who are "boy-lovers" or "dolled up." It is the Spartans who are lustily, ludicrously, and sensuously gay. This also accounts for the switch from serious to comic parody, because by setting free the anarchic possibilities of sexual play, a "trans-contextualization" occurs, i.e., an inversion as a resignified repetition revealing the pretext's ridiculousness. On the concept of comic ridiculing as parodic tradition, Linda Hutcheon claims: "As a subgenre of the comic, parody makes its model ludicrous." ${ }^{20}$ But she also warns that any anarchic-comic parody may have an authorizing effect: ${ }^{21}$

Nevertheless, parody's transgressions ultimately remain authorized authorized by the very norm it seeks to subvert. Even in mocking, parody reinforces; in formal terms, it inscribes the mocked conventions onto itself, thereby guaranteeing their continued existence.

This brings a reading of Meet the Spartans to a crucial moment that did not occur in this manner in 300 : does Meet the Spartans really (only) laugh at the exaggerated heterosexual manliness of the Spartans in 300 or at "Greek love" in more general terms?

Already in 1883, the British writer and critic John Addington Symonds wrote on Greek love as A Problem in Greek Ethics. ${ }^{22}$ Symonds' argument includes not only the thesis that Greek male homosexuality (paiderastia) was a gender-specific, i.e., male, practice and therefore caused a "problem" for Greek ethics, but that this in turn also remained problematic for modern ethics, since this, as Jeffrey Weeks states in reference to Symonds' emancipatory thesis, means "to establish, by using the Greek analogy, that [male] homosexuality could be accepted as part of the social mores

20 Hutcheon, A Theory of Parody, 51.

21 Ibid., 75 .

22 John Addington Symonds, A Problem in Greek Ethics: Being an Inquiry into the Phenomenon of Sexual Inversion (New York: Haskell House, 1971). 
of society"23 (original emphasis). Homosexuality as universal ethics on the one hand and yet based on a segregated gender notion on the other, obviously accounts for some of the ambivalences inherent in any reading of male homoeroticism in heroic genres, whether comic or otherwise. Even though harking back to a "Greek tradition" may serve as "potentially meaningful 'guide for life,' " David Halperin warns: ${ }^{24}$

If we are ever to discover who 'we' really are, it will be necessary to examine more closely the many respects in which Greek sexual practices differ from 'our own.'

To complicate things even more, the disclosure of the lacunae in the pretext 300 , brought about through the parodic excess of Greek homosexuality in Meet the Spartans, may furthermore be reinforced by looking at yet another generic citation. Both films rely to a great extent on the tradition of the historical sandal epic, which in the Italian variation of the peplum films have gained enormous popularity between the late 1950s (starting with Pietro Francisci's Hercules [Le fatiche di Ercole]) and the mid-196os. ${ }^{25}$ Robert Rushing claims that here undoubtedly a "classical" male genre has come into being that strongly implied subversive gender politics: how does a heterosexual male audience deal with the fact, he asks, that the peplum films show non-heteronormative spectacular performances of legions of almost naked, well-built, oil-shined male bodies? ${ }^{26}$

The hero must assume pose after pose to showcase his muscles, even when he is ostensibly relaxing.... He must also, of course, be clothed in a manner that shows off his physique - hence the name of the genre, the peplum, the loose-fitting, one-shouldered toga (but one should note that the peplum was an article of female clothing in ancient Greece). Very quickly, however, the hero takes off his peplum in favor of more revealing costuming: at times, the hero appears to be wearing nothing so much as a miniskirt or a cloth diaper.

Especially battle and torture scenes allow for a depiction of the male body as spectacle. The peplum has this in common with other male genres such

23 Jeffrey Weeks, Coming Out: Homosexual Politics in Britain from the Nineteenth Century to the Present (London: Quartet, 1977) 52.

24 David Halperin, One Hundred Years of Homosexuality: And Other Essays on Greek Love (London: Routledge, 1990) 1-2.

25 On alterity in American historical epics of this period, see Jan Timmer (347), who claims that while laughing at the foreign "other" in these films may weaken the foe's dangerous side, there is also the pitfall of building up new hierarchies of identity and alterity by infantilizing the "other."

26 Rushing, "Gentlemen Prefer Hercules," 164-165. 
as the Western, the horror film, and war and sports films. And yet, in the peplum such scenes remain the exception. Instead, these films stage the male body as erotic object throughout their narrative, not only in scenes of heightened physical activity. From this generic specificity, Rushing draws the conclusion that (1) the peplum represents a sort of proletarian fantasy, (2) it never was conceived of as a realistic, but rather as a postmodern ironic genre, and (3) it may come across as democratic, but actually tends towards authoritarianism. ${ }^{27}$ Kenneth MacKinnon even claims the principle pleasure of the male epic with its spectacular display of the male body lies in a phantasmatic satisfactions of masculinity which allows for passivity as well as activity. ${ }^{28}$ While he remarks that the male epic coasts "close to an open acknowledgment of the male spectator's eroticisation of the male," Paul Roen goes on to praise the peplum because it is: ${ }^{29}$

specifically tailored to suit the demands of a male homosexual audience with the films' dramatic emphasis on "rippling muscles, masculine camaraderie, and killing the bad guy (often as well-built as the good guy, and just as scantily clad)."

Hence the peplum goes "beyond gay camp, into the realm of soft core erotica." 30 Richard Dyer similarly attests the hybridity of this genre, but moves the discussion to the political: the ancient heroes in these Italian films were mostly played by American bodybuilders and should be seen within the context of a hegemonic discourse of the white, muscular male body. As such this steeled, trained body can be equated with an imperial desire for power: ${ }^{31}$

In short, the built body and the imperial enterprise are analogous. The built body sees the body as submitted to and glorified by the planning and ambition of the mind; colonial worlds are likewise represented as inchoate terrain needing the skill, sense, and vision of the coloniser to be brought to order. The muscle hero has landscaped his body with muscles and he controls them superbly and sagely; the lands of the muscle film are enfeebled or raw bodies requiring discipline. The built white male body and colonial enterprise act as mirrors of each other, and both, even as they display the white man's magnificent corporeality, tell of the spirit within.

27 Ibid., 166-167.

28 Kenneth MacKinnon, Uneasy Pleasures: The Male as Erotic Object (London: Cygnus Arts, 1997) 184.

29 Paul Roen, High Camp: A Gay Guide to Camp and Cult Films, vol. 1 (San Francisco: Leyland, 1994) 13.

30 Ibid.

31 Richard Dyer, White (London: Routledge, 1997) 165. 


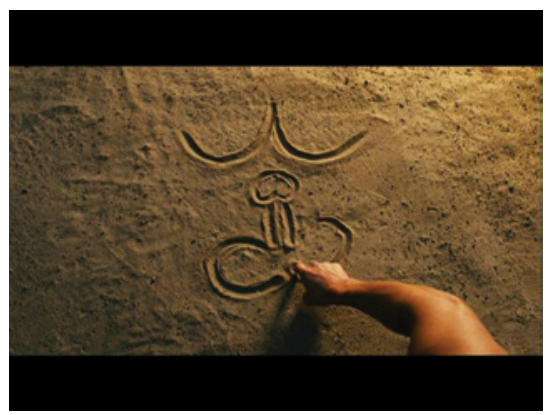

Figure 13

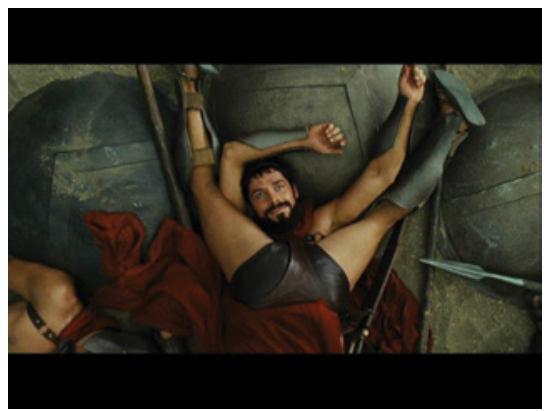

Figure 14

It is evident to what extent the male bodies of the Spartans undergo such physical routine in all films, how they are trained to be war machines and put to use in the name of the nation. The pressing question remains, however: who wears the sign of imperial power? Is it the Spartans, who as defenders of freedom are being turned into victims? Or the Persians, whose quantitative superiority compensate for their lack of individual bodily strength? The films answer these questions, at least on the diegetic level, in different manners: 300 leaves no doubt as to the physical superiority of the Spartans. Even though they succumb in battle, they remain victors because of the "spirit within." Meet the Spartans, with its portrayal of painted-on abs, clumsy behavior, silly disco dancing, and continuously showcased anal fixation (see Figures 13 \& 14), obviously makes fun of diverse pretexts and pop-cultural contexts, but ultimately the ambivalence cannot fully be erased as to whether on an extra-diegetic level this 
does not follow the ambiguous logic of what Hutcheon has called a reinscription of the ridiculed norm. ${ }^{32}$

\section{Perverse Persians? "Everybody Loves a Muscle Boi" and Post-9/11 Panics}

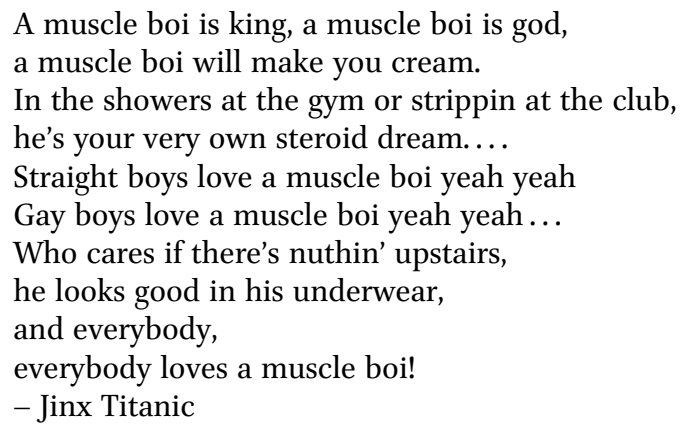

A third approach of reading spoofs of the Spartan three hundred tries to untangle the web of ambivalences by focusing on the performance of homoeroticism as it is crossed with oriental xenophobia. Here, another intertext gains importance: United 300, the short film which won the MTV award for Best Filmic Parody. It is a double parody on 300 as well as United 93, the latter focusing on the 9/11-terror attacks. As the director of United 300, Andy Signore, commented at the MTV-award ceremony, the film does not make fun of a tragedy but is meant as a tribute to all who fight tyranny. ${ }^{33}$ The film, as the comment implies, both picks up on the threat of terrorism and yet transcends the limitations of hastily drawn discriminatory politics therein. The short film shows the three hundred Spartans on board an airplane fighting terrorists who want to highjack the plane to Germany. Just as the Spartans defended the pass of Thermopylae, they here block the entrance to the plane's cockpit. A comic interlude occurs amidst the battle, when because of turbulences the "fasten seatbelts" signs light up and all comply docilely. The enemy "troops" fiercely fixate upon one another, but jump back to fighting action only after the signs are turned off again. Xerxes (Ken Gamble) wears the same "dolledup" costume as his counterpart in 300 but is less of a muscled hard body and more of a sleazy moron (see Figure 15).

\footnotetext{
32 Hutcheon, $A$ Theory of Parody.

33 “2007 MTV Movie Awards," accessed Dec. 3, 2009, http://www.mtv.com/videos/ misc/151824/united-30o-wins-best-movie-spoof.jhtml\#id=156og89.
} 


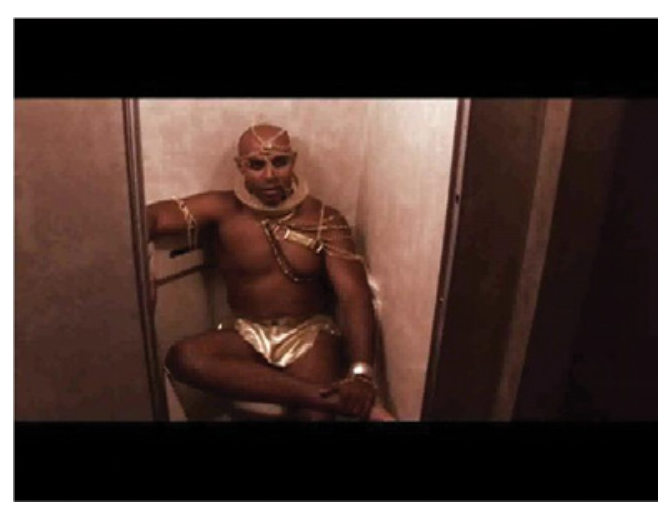

Figure 15

Significantly, his name has been changed to Jerxes, an allusion to both "jerk" and to "jerk off." This parodic ribaldry is heightened by the fact that Jerxes has withdrawn to the restroom during battle. Sitting on his "throne," he receives Leonidas. The ensuing dialogue is reduced to Jerxes' complaint that all Leonidas does is shout his part. This is also a comic comment on 300 and Leonidas' noisy declamations therein. The reference to United 93, on the other hand, gets more obvious when Leonidas warns him about the plan to force the plane to land. Jerxes retorts, "We'll be forced to land in Ohio!" to which Leonidas only laconically answers: "Then tonight, we dine in Cleveland!" Jerxes' final exclamation: “This is madness!" Originally, these were the words of the Persian messenger in 300 just before Leonidas throws him into the pit. Here, Leonidas kicks him out of the plane into the air with the farewell: "This is United!"

Paul Greengras' United 93 (2006) serves as foil for the short film. It is a filmic account of the events on board the United Airlines flight which was involved in the terror attacks of September 11, 2001. This is the plane that did not hit the Capitol in Washington, D.C. as planned, but due to the passengers' intervention was redirected towards Cleveland, Ohio, and ultimately crashed in the countryside. In an extremely shortened, but highly allusive way, United 300 picks up various elements from this film and mixes them together with allusions to 300 to create a wild slapstick parody. Not only do the Spartans look silly on board an airplane with their ancient warrior costumes, the mixture of white terrorists in plain everyday clothes with their Orientalized leader Jerxes in an antiquated costume also strikes the audience as totally incongruent. With his queer gear, he rather matches his Spartan adversaries, of whom one passenger wonders: "Who are the guys in the underwear?" 
The short film relies in its depiction of the Persian emperor on the homophilic androgyny of 300 twisting the stereotypical embodiment of "Oriental perversion" into a parody on the politics of Islamic terror. The clash of civilizations that in 300 is represented through stylized scenes of violence and sexual innuendos tinged with a fascist aesthetics has been taken here to its absurd extreme. In United 300 such crude humor unquestionably exposes and even subverts the homophobic racism and the politics of enemy stereotyping of its predecessors.

Already in 1962, Rudolph Maté's The zoo Spartans had obvious links to the contemporary dealings of the Cold War and was perceived as a landmark of the anti-Soviet propaganda film: ${ }^{34}$

This simply dripped with Cold War imagery, even to the extent of splashing across the screen uplifting slogans about the defence of freedom against slavery.

This film in turn served as inspirational backdrop for Frank Miller's graphic novel, the adaptation of which by Zack Snyder has then been read as allegory of the "War on Terror." Both films satisfy what Simona Slanička calls the desire for "grand narratives" in historical periods that are prone to great menace: ${ }^{35}$

Namely the 1950s with the imminence of the nuclear world war and the uncertainty caused by the 'invisible' and 'ubiquitous' Islamist terror after 2001's September 11th attacks.

Seth Tomko and Jenny Zimmerman, referring to Susan Faludi's earlier prediction, have interpreted the scenes of violence in 300 not only as glorification of male violence and belligerence but especially as adding fuel to the prejudices against the Middle East: ${ }^{36}$

34 Cartledge, Thermopylae, 193.

35 Simona Slanička, "Der Historienfilm als große Erzählung," in Mischa Meier and Simona Slanička, eds., Antike und Mittelalter im Film: Konstruktion - Dokumentation - Projektion (Köln: Böhlau, 2007) 436; translation mine. For the United States, the Vietnam War is yet another such historical crisis era calling for "grand narratives." See here especially Ted Post's film Go Tell the Spartans (1978, based on Daniel Ford's 1967 novel Incident at Muc Wa) about the early part of the Vietnam War in 1964. A unit of American military advisors in Vietnam prior to the major United States involvement find themselves caught in a helpless struggle against the Viet Cong. They are ambushed at a poorly-manned outpost that is near the scene of a massacre a decade earlier of French soldiers during the First Indochina War. The outpost is finally overwhelmed with only one American surviving. The film's title refers to the Greek poet Simonides' famous epitaph engraved on a commemorative stone at the burial ground at Thermopylae: "Go tell the Spartans, stranger passing by, that here, obedient to their laws, we lie."

36 Seth Tomko and Jenny Zimmerman, "Back to the '70s," The Atlantic Monthly 302 (2008) 14. See also Dennis Behreandt's remark on the release of 300 : "For Americans, with troops on the ground in the heart of the ancient Persian Empire in Iraq and Afghanistan, 
In 300 , we see freedom-loving Occidental men standing for vaguely democratic self-governance against what can only be described as a mob of swarthy foreign invaders directed by a megalomaniacal religious fanatic intent on subjugating or destroying the birthplace of Western ideology. Even the sacrifice made by the 300 Spartans is made to seem glorious compared to the empty and treacherous temporary victory of the Persians.

There are, of course, also critics who believe that the film's visual aesthetics are a tribute to the graphic novel's origins and thus generically imbued with exaggerations and foreshortenings, which actually suit the myth of this particular historical event quite well: ${ }^{37}$

The battle of Thermopylae no longer exists as mere fact. By now it even transcends legend, moving onto the ground of myth, where action and motivations seem guided less by soldiers and generals than by the gods, who are teaching lessons about courage, sacrifice and freedom.

The dominant reception of Greek antiquity as the cradle of Western civilization and democracy has been contested and rejected, prominently by Martin Bernal, who in his revisionist study, Black Athena, speaks of the "fabrication of ancient Greece" as birth of European culture. Regarding the Afro-Asian roots of Greek antiquity he demands "not only to rethink the fundamental bases of 'Western Civilization' but also to recognize the penetration of racism and 'continental chauvinism' into all our historiography, or philosophy of writing history" (2). He thinks it fatal to rely on the notion of a racially pure, i.e., white, ancient Greece for the sake of one's own legitimization, especially when "race" is marked solely as being "other" while "we" remain racially unmarked. This unmarked but implicitly "white" category then continues to be unquestioned as "a category of oppression operating through racial formations, racial ideologies, racialized fantasies, and racisms," as Scott Bravmann remarks. ${ }^{38}$ There can never be an "innocent" treatment of antiquity, especially when it comes to reconstruct social definitions of sexuality, because they: ${ }^{39}$

and with speculation that the war will spill over into the Persian homeland of Iran, history seems finally, in some way, to have come full circle after almost 2,500 years. Instead of Sparta, now it is America that faces the threat from Persia. In its retelling of the story of Thermopylae, 300 embraces the mythos of the battle rather than the historical truth of the era, and in doing so becomes an elaborate bit of present-day pro-war propaganda." Dennis Behreandt, "The Meaning of 300: in the Hands of Filmmakers, the Legendary Spartan Stand at Thermopylae Becomes Pro-War Political Propaganda in the New Film 30o," The New American 23.7 (April 2, 2007), accessed november 14, 2009, www.questia.com.

37 John Petrakis, "Comic-Book Violence," The Christian Century 124.8 (April 17, 2007) 42.

38 Bravmann, Queer Fictions of the Past, 67.

39 Ibid., 50. 
cannot be severed from the larger cultural projects of the fabrication of ancient Greece and the particular set of meanings ascribed to it, including the heavy political and cultural baggage of deep-seated theories of civilization, discourses on national survival, and racial belief systems.

A limited approach to Greek antiquity that leaves aside the consideration of racist discrimination therefore repeats a historical fiction that has been retrospectively fabricated in the first place. It also reenacts the racisms as well as other sorts of discrimination inscribed into such fictionalization.

The films at stake here fall into a period when the United States during George W. Bush's presidency gained strong support from a Christian fundamentalism leading to a (unsuccessful) proposal of a constitutional amendment in 2004 for declaring "gay marriage" as unconstitutional. Had this proposal, which was strongly supported by the President, been ratified, it would have been the first amendment to the constitution to install a model for discrimination instead of eliminating discrimination. Even though the law did not pass, this effort nevertheless speaks of a cultural climate in which it has become possible to repeal the already legalized possibility of a homosexual marriage in seemingly gay-friendly California. If a film like 300 represents the Spartans as white Greeks and the Persians as a hybrid mixture of Afro-Asian races, such mythicized stereotypes of inclusion and exclusion are invoked again allowing for analogies in contemporary politics. Robert Rushing ironically yet succinctly points out the aesthetic-political agenda of 300 as pertaining to the tradition of the performance of ambiguous heteronormativity in the historical epic: ${ }^{40}$

Snyder's 300 presses the modern peplum into similar work, imaging a cruel and authoritarian society (the Spartans) who turn out to be the only defenders of "freedom" (the freedom of infanticide and rape, evidently) against barbaric hordes from the East (the Persians) who wish to destroy their way of life. This, too, presses present-day desires (that, say, the invasion of Iraq might have been justified) into a phantasmatic past in which the Spartans actually quote members of the Bush administration to justify their call to war: "freedom isn't free," declares Queen Gorgo (Lena Headey).

In contrast, the two spoofs on 300 certainly push the Spartan legend to its absurd comic extremes, unearthing the cartoonish qualities of a frozen myth in the case of Meet the Spartans and disclosing the exaggerated cult of maleness as part of the war machinery in the case of United 300 . If one additionally wants to view parody as educational means that depends not

40 Rushing, "Gentlemen Prefer Hercules," 73. 
only on humor but also on negotiating deeper insights through humor, both spoofs may be seen as satirical parodies. ${ }^{41}$ In this sense, they are more than just a parody on the aesthetic norms of their pretexts. They also address social norms and as such take part in the longstanding central agenda of satire. The Spartans dancing to war to Gloria Gaynor's "I Will Survive" in Meet the Spartans and Jinx Titanic and his band Super 8 Cum Shot singing "Everybody Loves a Muscle Boi" during the closing credits of United 30o: these are unambiguously queer moments satirizing the present reemergence of an ancient cult of the male warrior. At the same time, these are instances of a queer alliance across the boundaries of nation, race, and religion as the claim "This is United!" has already suggested as parodic double entendre. Such code switches make serious fun of the politics of heteronormativity by queering the celebrated legend of the three hundred Spartans. As satiric parody, the "just cause" of the war on terrorism is thus disclosed as absurd battle against all that seems other, foreign, treacherous, barbarous, and perverse. Albeit waged in the name of freedom and democracy, the semiotic power of words and images inherent in such a war are dislodged and exposed as deeply anti-social, heteronormative, and racist elements pertaining to a white supremacist and imperialist ideology of "we."

\section{Works Cited}

“2007 MTV Movie Awards,” accessed Dec. 3, 2009, http://www.mtv.com/videos/misc/151824/ united-300-wins-best-movie-spoof.jhtml\#id=1560989.

Albertz, Anuschka. Exemplarisches Heldentum: Die Rezeptionsgeschichte der Schlacht an den Thermopylen von der Antike bis zur Gegenwart (München: Oldenbourg, 2006).

Behreandt, Dennis. "The Meaning of 300: In the Hands of Filmmakers, the Legendary Spartan Stand at Thermopylae Becomes Pro-War Political Propaganda in the New Film 3oo," The New American 23.7 (April 2, 2007), accessed November 14, 2009, www.questia.com.

Bernal, Martin. Black Athena: the Afroasiatic Roots of Classical Civilization, Volume I: The Fabrication of Ancient Greece 1785-1985 (New Brunswick: Rutgers University Press, 1987).

Bradford, Ernle. The Year of Thermopylae (London: Macmillan, 1980).

Bravmann, Scott. Queer Fictions of the Past: History, Culture, and Difference (Cambridge: Cambridge University Press, 1997).

Cartledge, Paul. Thermopylae: The Battle That Changed the World (New York: Vintage, 2006).

Culler, Jonathan. Structuralist Poetics: Structuralism, Linguistics and the Study of Literature (London: Routledge \& Kegan Paul, 1975).

Davis, Joe Lee. "Criticism and Parody," Thought 26 (1951) 180-204.

Dyer, Richard. White (London: Routledge, 1997).

41 Gehring, Parody as Film Genre, 3. 
Faludi, Susan. Stiffed: The Betrayal of the American Man (New York: Harper Perennial, 2000).

Fields, Nic. Thermopylae 48o BC: Last Stand of the 300 (Oxford: Osprey, 2007).

Frayling, Christopher. Spaghetti Westerns: Cowboys and Europeans from Karl May to Sergio Leone (London: Routledge, 1981).

Gehring, Wes D. Parody as Film Genre: Never Give a Saga an Even Break (Westport: Greenwood, 1999).

Günsberg, Maggie. "Heroic Bodies: The Culture of Masculinity in Peplums," in Italian Cinema: Gender and Genre (Houndsmill: Palgrave Macmillan, 2005) 97-132.

Halperin, David. One Hundred Years of Homosexuality: And Other Essays on Greek Love (London: Routledge, 1990).

Herodotus of Halicarnassus. The Histories (Trans. A.D. Godley; Pax Librorum, 2010), accessed June 6, 2010, http://www.paxlibrorum.com/ebooks/\#histories.

Hignett, Charles. Xerxes' Invasion of Greece (Oxford: Clarendon, 1963).

Hutcheon, Linda. A Theory of Parody: The Teachings of Twentieth-Century Art Forms (Urbana: University of Illinois Press, 2000).

MacKinnon, Kenneth. Uneasy Pleasures: The Male as Erotic Object (London: Cygnus Arts, 1997).

Miller, Frank and Lynn Varley. 300 (Milwaukie, OR: Dark Horse Books, 1999).

Neale, Steve. "War Films," Genre and Hollywood (London: Routledge, 2000) 125-133.

Petrakis, John. "Comic-Book Violence," The Christian Century 124.8 (April 17, 2007) 42.

Roen, Paul. High Camp: A Gay Guide to Camp and Cult Films, vol. 1 (San Francisco: Leyland, 1994).

Rushing, Robert A. "Gentlemen Prefer Hercules: Desire / Identification / Beefcake," Camera Obscura 69.3 (2008) 159-191.

Seymour, Gene. "On the Field of This Battle, War is Swell." Newsday, March 9, 2007, accessed December 2, 2009, http://www.allbusiness.com/humanities-social-science/ history/11900802-1.html.

Slanička, Simona. "Der Historienfilm als große Erzählung," in Mischa Meier and Simona Slanička, eds., Antike und Mittelalter im Film: Konstruktion - Dokumentation - Projektion (Köln: Böhlau, 2007) 427-437.

Streeter, William W. "Confidence Needs to Be Led," ABA Banking Journal 100.1 (2008) 4, accessed June 4, 2010, http://www.nxtbook.com/nxtbooks/sb/ababjo108/index.php? startid $=4$.

Symonds, John Addington. A Problem in Greek Ethics: Being an Inquiry into the Phenomenon of Sexual Inversion (New York: Haskell House, 1971).

Szemler, George J., William J. Cherf and John C. Kraft. Thermopylai: Myth and Reality in 480 B.C. (Chicago: Ares, 1996).

Timmer, Jan. "Fremdheit im Antikfilm" Mischa Meier and Simona Slanička, eds., Antike und Mittelalter im Film: Konstruktion - Dokumentation - Projektion (Köln: Böhlau, 2007) 343-358.

Titanic, Jinx. "Everybody Loves a Muscle Boi," accessed December 3, 2009, http://www .jinxtitanic.com/lyrics/muscleboi.html.

Tomko, Seth and Jenny Zimmerman. "Back to the '7os," The Atlantic Monthly 302 (2008) 14.

Weeks, Jeffrey. Coming Out: Homosexual Politics in Britain from the Nineteenth Century to the Present (London: Quartet, 1977).

Winkler, Martin M., ed. Classical Myth and Culture in the Cinema (Oxford: Oxford University Press, 2001). 



\title{
THE WOMANIZING OF MARK ANTONY: \\ VIRILE RUTHLESSNESS AND REDEMPTIVE CROSS-DRESSING \\ IN ROME, SEASON TWO
}

\author{
Margaret M. Toscano
}

This essay explores the way Roman masculinity functions as a signifier for imperial potency and domination, vulnerability, and loss, in Season Two of the acclaimed HBO-BBC series Rome. I argue that the development of the character of Mark Antony is pivotal for understanding how gender and sex are used as metaphors for the movement of power and redemption within the story. After the death of Julius Caesar, the eternal city erupts into mad chaos and a ruthless grab for power. Only those with steel nerves and blades can survive in this environment. Raw, masculine strength is needed to take control. What is respected in this context fits with traditional Roman notions of maleness - the ideal of the strong, "invincible warrior," who penetrates with but is not penetrated by his sword and his penis. ${ }^{1}$ Softness and vulnerability are not just despised as womanly; they presage the loss of empire.

In her essay, "Spectacle of Sex: Bodies on Display in Rome," Stacie Raucci argues that what is original about the way sexuality is treated in Season One of the HBO-BBC series is the way "the virtue and strength of men are contingent upon sexual prowess, and their arena is the bedroom, not just the battlefield." 2 She further argues that Mark Antony is "the primary sex symbol of the series" and that it is "by exhibiting his body, not by fighting, that Antony demonstrates his virility."3 Something fundamental about this equation changes, however, during the second season of Rome,

1 Octavian uses the term "invincible warrior" in Episode 8 to describe the ideal Roman male. Jonathan Walters, "Invading the Roman Body: Manliness and Impenetrability in Roman Thought," Judith P. Hallett and Marilyn B. Skinner, eds., Roman Sexualities (Princeton: Princeton University Press, 1997) 29-43, argues (30) that Roman discourse "defined men as impenetrable penetrators" in a way "that characterized those of high social status as being able to defend the boundaries of their body from invasive assaults of all kinds." Kirk Ormand, Controlling Desires: Sexuality in Ancient Greece and Rome (Westport, CT and London: Praeger, 2009), reinforces this model as he summarizes the scholarship on Roman masculinity from the past few decades.

2 Stacie Raucci, "Spectacle of Sex: Bodies on Display in Rome," in Monica Cyrino, ed., Rome, Season One: History Makes Television (Oxford: Blackwell, 2008) 208.

3 Ibid., 208-209. 
which throws everything off balance. Now the male body is not merely on display as a sign of prowess and strength. Instead, the male body is under attack as a representation of Roman invulnerability. That the noble statesman, Marcus Tullius Cicero, would end with his body broken into parts, with his hands and head displayed in the Forum, is not simply a warning to others but also a sign of fractured masculinity.

The question is whether any body, including the aristocratic male body, can remain inviolable in the midst of the vicious and violent power struggles of a monumental civil war. As the various factions, both among the plebs and elites, fight for control of Rome and empire, manliness itself becomes a contested category. In order to gain mastery over one's rivals, a man needs to penetrate not only his enemy's camp but also his manhood. Castration and anal rape are the actual mechanisms used by the plebs in the second season of Rome, whereas the ruling class uses more subtle weapons of political strategizing to unman their competitors. The gang boss Erastes Fulmen attacks Vorenus' person as the paterfamilias by claiming he "fucked" Vorenus' children before he killed them. Quintus Bubo is castrated because he defiled Carbo's nephew; then in retaliation Carbo is anally penetrated while using the latrine, which leads to escalated violence among the gangs on the Aventine. When Pullo bites off Memmio's tongue, reducing him to an animal in a cage, Memmio loses his manhood by losing his ability to speak and negotiate. And when the King of Bithynia says he wants to "see a Roman woman fucked by a baboon," it is not just spectacle he desires but the humiliation of the category "Roman" because "Roman woman" is still a class above "foreign man." When Atia resorts to male techniques to torture her old enemy Servilla by having her anally raped, it is at this point that Timon the Jew finally refuses to cooperate, as he shouts "I'm not an animal." He may not be able to claim Roman manliness, but he clings at the end to his humanness. ${ }^{4}$

Mark Antony, played by James Purefoy, begins the second season where he ended the first. As the best soldier in Rome, he is beloved by the people; he is the epitome of Roman maleness with a hard body and a hard-on that seemingly never abates. As such, he is the fit avenger of Julius Caesar's death. On the day of Caesar's funeral, he refuses to rise from the bed he shares with Atia until, as he says, "I've fucked someone." He jokingly says that the old slave woman Merula will have to do when

4 As Walters (36) illustrates, "the right to protect one's body from the sexual assault of another" was a right connected to Roman citizenship and class, which adds to Atia's humiliation of Servilla. 
Atia says she does not have time or the inclination. Calling him the "king of goats," Atia sends for one of the slave girls to meet Antony's need.

Antony's virility never wanes in the series; he remains sexualized and potent to his death in the last scenes. And his beautiful, fit body never becomes soft. But his masculinity changes as he lets himself be influenced by the input of the women around him that eventually softens him emotionally, leading to his tragic end. In the process, his character also changes and deepens as he feels the impact of his feelings for women and their feelings, which was not true in the first season. When Antony first encounters Cleopatra in Episode 2, Season Two, on her return to Rome, she tells him that he has "a changeable look" about him. Astute viewers will recall the connection the ancients made between women and instability, as expressed in Virgil's (Aeneid 4.569-70) well-known line: "Varium et mutabile semper femina" - "woman is always a fickle and changeable thing." That it is Antony who is changeable is a sign of his inclination toward feminization. When Octavian is debating about what to do with Antony and the grain problem in Episode 9, he remarks, "Who knows what Cleopatra has made him do. Antony was always a fool for his women."

It is not just that Antony has an eye for pretty women and a lust for their bodies, though he does throughout the series. In Episode 7, at Jocasta's wedding to Posca, Antony winks at a pretty female slave while he passively talks of marriage to Atia. It is not just that Antony's overwhelming passion for Cleopatra undoes his soldierly calculation and his sense of Roman masculinity. The important factor is that he begins to care about the concerns of women as the series progresses. In the private scenes between Antony and Cleopatra in Egypt, we see both a steamy, erotic passion and an intimate tenderness. "What's the matter, baby, are you sad?" he asks softly as he touches her affectionately in their last hours together. They talk about how happy their life together has been, almost like they are an ordinary married couple. ${ }^{5}$ Although Antony begins as the stereotypical womanizer who objectifies women, he gradually opens up to their feelings, as seen in his relationships with both Cleopatra and Atia.

Atia is crucial for understanding Antony's character development because she adds another dimension to what it means for him to be in the power of women. If Cleopatra were the only one who influenced him, then it could be attributed to the mysterious power of the foreign witch

\footnotetext{
${ }^{5}$ In James Purefoy's commentary about the relationship between "Antony and Cleopatra" recorded in the bonus features of the DVD, he movingly talks about the deep love between the mythic lovers.
} 
queen who gets him under her magical spell, or simply the power of eros that stimulates their monumental passion. But the fact that Antony develops a real relationship with Atia after all their years together as ardent lovers shows something more is happening to him as the series moves along. This is seen when Antony comes to Atia's door just before he leaves for Egypt, forced from Rome by Octavian who is angry at what he sees as the debauchery of his family. Like a lovesick man (amans) at the doorstep of his mistress (domina) in Roman elegiac poetry, Antony waits outside Atia's house, denied access by Octavian's guards but calling out his lover's name until she appears. After he tells her he is leaving, he finally gives her hope that he shares her love by telling her that he will send for her. When she asks when that will be, he promises her solemnly that they must be patient. His kissing of her hand signifies more than a mouth kiss would in this context because it shows respect, affection, and commitment. "I'll send for you," he says sincerely as he looks after her departing figure in longing sadness.

Of course Antony never keeps his promise. And when Atia shows up at his palace door in Alexandria with Octavia in a visual reworking of the earlier scene, Antony admits to his wife Cleopatra that he no longer loves Atia. But he will not deny that he still has feelings for her when Cleopatra tries to force some action from him by suggesting that they either invite the women in, kill them, or both. "Of course I no longer love her," Antony says to Cleopatra, "but neither do I think she needs public humiliation. I don't think she knows that her fucking son has manipulated her for his own ends." The fact that Antony does not want Atia demeaned more than she has been already shows his concern for her as a person because he wants no harm to come to her.

Ironically, as Antony is womanized by his womanizing, his character is arguably more sympathetic. I have chosen to use the term "womanization" of Mark Antony in my title rather than the more familiar "feminization" because I believe that the transformation of Antony in this series is different than the usual portrayals of Antony being brought under feminine power. In the case of both Atia and Cleopatra, an interactive process is involved; what starts out as a passionate sexual affair becomes a marriage on several levels. Antony lets himself be penetrated emotionally by both of these women; he is vulnerable to them because he loves them and cares about their welfare. The mutability of terms and relationships is shown in the way Antony uses the vow "on Juno's cunt" repeatedly in the Season Two. While the vulgar Anglo-Saxon word for female genitalia is used derogatorily on a number of occasions in the Season Two when 
men who want to debase other men turn them into subjugated women, Antony does not use the term in this way. Rather, he seems to be acknowledging the power of this female deity as the goddess of marriage.

While there is a long and varied history of representing Antony's feminization in text and film, Rome's Antony stands out for the nature of his transformation. Whether it is to be found in such ancient writers as Cicero and Plutarch or in modern films from Cecil B. Demille's Cleopatra (1934) with Claudette Colbert to Joseph L. Mankiewicz's epic version with Elizabeth Taylor and Richard Burton, or even in Franc Roddam's 1999 Hallmark made-for-television production of Cleopatra, the traditional feminization of Antony involves the demeaning of Roman manhood through Antony's debauched living and decadence, intensified once he comes under the power of Cleopatra. To be feminine is to give in to personal pleasure and desire at the expense of public and familial duty in each of these contexts. As Anthony Corbeill demonstrates in his exploration of this topos in Roman political speeches, it was common for a speaker to accuse his opponent of being an effeminate male, which was associated with the excesses of profligate spending, banqueting, and orgies: "late Republican invective against effeminacy tended to be conflated with fears of the immoderate feast." 6

Such associations are especially evident in Cicero's famous denunciation of Mark Antony in his Second Philippic, where he accuses Antony of playing the part of the submissive and passive female in a sexual relationship with Curio in his youth, which prefigures his later moral degeneracy and lack of self-control. ${ }^{7}$ Describing one period of Antony's debauched life while he was in residence at Varro's villa, Cicero (Philippic 2.105, 41) lambastes his enemy: "the whole place rang with the voices of drunken men; the pavements swam with wine; the walls were wet; boys of free birth were consorting with those let for hire; harlots with mothers of families."8 Here Cicero connects the drunkenness and licentiousness of Antony's wild parties with the breakdown of social order in Rome. Roman manliness is about maintaining the boundaries of class and gender that keep Roman power inviolable. For a Roman "vir" to play the part of a woman

\footnotetext{
6 Anthony Corbeill, "Dining Deviants in Roman Political Invective," in Hallett and Skinner, eds., Roman Sexualities, 115 .

7 John T. Ramsey, ed., Cicero: Philippics I-II (Cambridge: Cambridge University Press, 2003) 227 , observes that it was common practice for Roman orators to accuse their political opponents of being a passive partner in a homosexual relationship.

8 The translation here is from Walter C.A. Ker, trans. and ed., Cicero: Philippics (Cambridge, MA: Harvard University Press, 1926).
} 
in any way was to threaten the structure and therefore the safety of the Roman state.

While Cicero's railing against Antony is portrayed in Episode 3 of Season Two, the new context reconfigures its meaning. All of the original accusations are there. Cicero, in absentia, calls Antony "a drink-sodden, sex-addled wreck" who was "bankrupt even before coming of age." Blaming Antony for the current war and destruction, Cicero calls him "Rome's Helen of Troy," adding that "a woman's role has always suited you best." As the senate house clears out since all can see Antony's reaction and guess the consequences, the senator who is reading Cicero's words for him hesitates and trembles in fear before reading the last line, only proceeding when Antony threatens him. But no sooner is the last line out of his mouth, than Antony springs forward and seizes the metal scrollholder, with which he brutally beats the reader to death. For most viewers, who assuredly will not be familiar with Cicero's Second Philippic, the accusation of femininity is not an accurate portrayal of Antony up to this point in the series since he has been the epitome of the macho fighter, the "brawler," as Jonathan Stamp calls him in his commentary. ${ }^{9}$ Rather, Cicero's speech is a foreshadowing of what is to come when Antony meets Cleopatra in Alexandria. Stamp asserts that Antony "becomes effeminate through his association with Cleopatra," which reflects Plutarch's portrayal of Antony.

Though Cicero was one of Plutarch's main sources for his life of Antony, Plutarch ignores the supposedly erotic nature of Antony's youthful relationship with Curio. ${ }^{10}$ Instead, Plutarch focuses on the tragic tension between Antony's outstanding characteristics (bravery, generosity, great military leadership, eloquence, and forthrightness) and his personal weaknesses (love of pleasure, debauchery, ambition, boastfulness, and susceptibility to flattery) that made him open to Cleopatra's powerful charms and control. Plutarch associates the unmanning of Antony with the fact that he had "surrendered" his authority to a woman and had become a mere "appendage" to her $\left(5^{0}, 5^{2}\right) .{ }^{11}$ Plutarch describes Antony's appearance as masculine and handsome, with his "virile" likeness to Hercules (4). It is Cleopatra and her drugs that weaken the great Roman so that he is

9 This is in one of the extra features on Disc V: "Antony and Cleopatra."

10 C.B.R. Pelling, ed., Plutarch: Life of Antony (Cambridge: Cambridge University Press, 1988), 118, notes this but adds that still Antony was accused of being passive in his relationships with others, such as Fulvia, not just Cleopatra.

11 Quotations are from Volume IX of Bernadotte Perrin, trans. and ed., Plutarch's Lives (Cambridge, MA: Harvard University Press, 1920). 


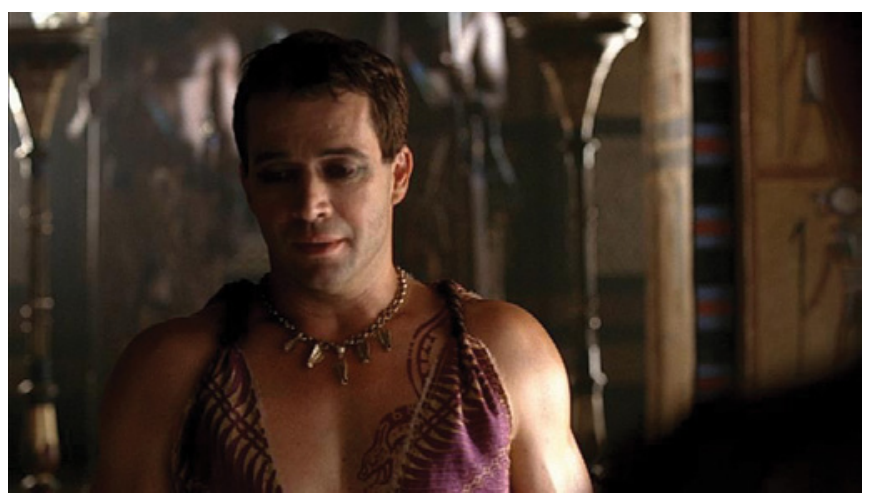

Figure 1

no longer "master of himself" (6o). Such a portrayal of Antony's loss of full manhood is also adopted by DeMille, Mankiewicz, and Roddam.

Rome's Antony shares this sense of disgrace for the corruption of his Roman maleness, but his feminization goes much further than any Antony before him because of his flamboyant cross-dressing. His drastic change is represented visually and vividly in the last two episodes of Season Two where he puts on feminine garb and make-up, reflecting what the Romans saw as the degenerate softness of Egypt and the East, which they despised as womanly. ${ }^{12}$ Antony appears in a series of women's attire in these scenes, but the purple gown he wears after submitting to Cleopatra regarding Atia's treatment is the most strikingly feminine, with its print and deep-cut neckline (see Figure 1). Antony dons this dress after his passionate fight with the Egyptian queen that ends in rough sex, reflecting her domination of him sexually and psychologically. The femininity of the purple gown and Antony's make-up is made stronger by its contrast with Vorenus' Roman soldier's outfit. Antony has come to ask Vorenus whether he has whisked the Roman women out of danger and is therefore relieved to find they are gone. With his usual honesty, Vorenus informs Antony that Octavia left him a message: "Sir, your wife instructed me to tell you that you are cowardly scum." When Antony assures Vorenus that he wants to know his opinion about the matter, the soldier tells his commander that Antony is no coward but he does have a "sickness of soul."

12 Corbeill, "Dining Deviants in Roman Political Invective," 107, explains how the Roman "fear of Hellenic or Eastern influence" was linked with Roman wariness about the "effeminate man." Both threatened the power of the Roman male by "the infusion of different ways of thinking about government and society." 
Vorenus' Romanness stands in stark contrast with Antony's increasingly Egyptian appearance. Rome's Antony is also more orientalized than any Antony before him, represented visually by his Egyptian eye make-up, body paint, and tattoos, which add to his womanly demeanor. The masculine hardness (duritia) of Vorenus is juxtaposed with Antony's feminine softness (mollitia).$^{13}$ And yet there is ironic tension in Antony's appearance. While his dress is soft, his body, still very evident under his clothing, is hard and very masculine in appearance, as is his stance and walk. I believe that this disjunction adds to the "queering" of Mark Antony in the last two episodes of the finale to the Rome series. As Donald Hall points out in his book on Queer Theories, "queerness" is not so much about sexual orientation as it is about "a questioning of the conventional."14 To be queer is "to abrade the classifications, to sit athwart conventional categories or traverse several"; it is to occupy the "lower half" of a "hierarchical binary"; it is about unmooring "social systems and identities." ${ }^{15}$ The transvestite Antony traverses categories of male and female, Roman and foreigner, soft and hard, soldier and prostitute.

Thus, the "queering" of Mark Antony represents much more than the loss of power of a great Roman general as he gives in to debauchery, drunkenness, lack of soldierly discipline, and old-fashioned Roman virtues. The "orientalizing" and "womanizing" of Mark Antony is not simply about the deterioration of a Roman man; it is also paradoxically about questioning the destructive forces of a virile imperialism. The macho Antony appearing as an Egyptian hermaphrodite questions the very notion of imperialism. At what price is such power bought? My reading of Season Two suggests that the filmmakers subvert both the category "Roman" and the category "masculine" in order to critique imperial aspirations that inevitably lead to carnage and destruction, especially of the most vulnerable elements of society, such as Vorenus' children. ${ }^{16}$

13 Ormand, Controlling Desires, 137, explains the importance of these Roman terms for the categorization of male and female gender and sexuality. In her "Introduction" to Roman Sexualities, 12-13, Marilyn Skinner notes how the "softness" of female sexuality was linked with "transvestite theatrical fantasies" in Roman literature.

14 Donald E. Hall, Queer Theories (New York: Palgrave MacMillan, 2003) 7; Hall (4) sees both Judith Butler, Bodies That Matter: On the Discursive Limits of "Sex" (London and New York: Routledge, 1993) and Eve Kosofsky Sedgwick, Epistemology of the Closet (Berkeley and Los Angeles: University of California Press, 1990) as his intellectual and theoretical models.

15 Ibid., 13-14.

16 In his commentary in the "Antony and Cleopatra" bonus feature, Jonathan Stamp says that history takes on a mythic quality when it "reflects contemporary concerns." The essays in Sandra R. Joshel, Margaret Malamud, and Donald T. McGuire, Jr., eds., Imperial 
This interrogation of power is especially evident in the contrasting masculinities of Antony and Octavian, where there is a chiastic reversal in the series. Antony's and Octavian's stars cross, as do their swords, at least metaphorically. The softening of Antony is contrasted with the hardening of Octavian, who begins Season Two as a slightly effeminate adolescent still under the influence of women. But as Octavian rises to power, he gains virility by ignoring the womanly pleas around him. Three scenes mark the crisscrossed movement of these two important male figures, both for history and the series.

The first is in Episode 2, where Octavian is still played by the younger actor, Max Pirkis. He announces to his mother and Antony that he has sold his goods to pay the plebs their promised legacy from Julius Caesar and that he intends to enter public life and therefore needs a public display of unity from his family. When Antony asks him "who the fuck" he thinks he is, he answers, "Caesar's son." A violent, physical fight ensues, stirred on by Octavian calling his mother a "whore" and each man slapping the other. Though Antony could clearly have killed his opponent, he is restrained by his feelings for Atia. But he tells "the boy": "You're lucky you're breathing." To which Octavian replies: "You're not fit to lead Rome."

The second scene is at the Battle of Philippi in Episode 6. While Octavian is now played by the older actor, Simon Woods, who is virile but youthful looking, he still fights against the epithet "boy," though he has already outmaneuvered Antony in Gaul without entering the conflict himself. Here the manly and experienced soldier Antony is contrasted with the inexperienced Octavian, who, unlike the other Roman leaders, never enters the actual battle. In this scene we see Antony at his best as a soldier who is manly and brave in the one elaborate battle scene depicted in both seasons of the Rome series. But Antony is also realistic about the confusion and mess of battle. He says, "when in doubt, attack"; and "watch, boy, this is how history is made." But when it is all over, Antony also tells Octavian that victory is "smoke, shit, and rotting flesh." The power balance between the two men will soon shift.

The third scene takes place in Episode 8 after Octavian learns from Maecenas that Antony's marriage to his sister Octavia is a sham since Antony is still having relations with Atia and Octavia is involved with Octavian's other close friend Agrippa. When Octavia makes a joke about

Projections: Ancient Rome in Modern Popular Culture (Baltimore and London: Johns Hopkins University Press, 2001) all argue that this is one of the appeals of the image of Rome for modern filmmakers. 
being in a form of "benign slavery" under Octavian's rule over the family, he protests on the basis of moral, as well as legal authority. "I am master of this family," he says, "and you have rebelled against me." He condemns both his mother and sister for their adulteries, exclaiming that he expected no better from his mother but felt Octavia owed him more since he had shown her nothing but love. When Antony stands up for Octavia as her legal husband, Octavian tells his political rival that the people will denounce him when they find out that Antony wears "cuckold horns." Octavian goes on: "I will publish your shame; you will be a figure of fun; your soldiers will mock you behind your back." When Antony begins to raise his fist, Octavian says, "Go on, strike me; see what will happen." Antony controls himself, but retorts, "You would disgrace your sister?" Octavian responds that she has already disgraced herself. After Antony leaves, powerless to do anything else, and when Atia and Octavia now realize they will be under house arrest, Octavia tells Livia, her new sister-in-law: "You are marrying a monster."

Octavia's comment encapsulates the dramatic question surrounding Octavian's character in Season Two. Has he bought imperial power at the price of ruthless monstrosity? Though he realizes that others see him as cold and heartless, he accepts this as the price of ruling, trained as he is in philosophy. When Octavian asks Pullo whom the people are blaming for the grain shortage, expecting a forthright answer, Pullo does not disappoint him: "You - you are the man in charge." Pullo explains that the people do not believe the newsreader when he puts the blame on Antony because they still love him; but they do see Octavian as distant and cold.

It is Octavian's virile, hard body that offers the spectacle of manliness for the viewers in the second season of Rome. Other than Brutus' in the rebirth scene, Octavian's body is the one we see the most - from several angles as he pumps his young wife Livia vigorously in Episode 9. But at the same time, Octavian's virility and thus maleness is also interrogated because he can only be aroused by sadistic roughness, not by feminine allurement. Should Gaius Octavian Caesar, as the first citizen in Rome, be the model for male sexuality? When Octavian questions Livia in the previous episode to see if she will make a suitable spouse, he asks her whether her current husband or father has ever beaten her. She assures him that they have had no reason; to which he answers that he shall on occasion beat her when she marries him. But he tells her that she should take no offense from it. He will only do it because it gives him "sexual pleasure."

While Octavian has little if any compassion, he prides himself on his morality and purity. In a speech to the wealthy women of Rome about 
moral reform in Episode 8, he asserts that it is "the women of Rome with their steely virtue and chaste morals who have conquered the world." He lauds them for "their virtuous light" that allows men to trod "the perilous paths of glory." He compares them to the "she-wolf who suckled Romulus and Remus" because they "have raised a nation of wise statesmen and invincible warriors." He thanks them for their contributions and assures them that when the time is right he will enact laws that reward virtue and severely punish moral infractions against marriage. When Maecenas amusedly compliments him later for his diplomacy, Octavian replies with all seriousness that he meant "every word."

This scene is overlaid with irony on several levels. First, while Octavian is delivering his impassioned speech about the need for decency in order for Rome to thrive, the viewers are presented with a visual montage, first of Antony and Atia engaged in passionate sex in one frame, then of Agrippa and Octavia making love in another, followed by Gaia emerging from a shop where she has bought poison to destroy Eirene. Part of the irony is that while betrayal of marriage is clearly shown in these scenes, so is love and fidelity because both Atia and Octavia are engaged in love affairs that combine sex with intimate relationship and commitment. For the first time, both women are shown emotionally happy in bed with their lovers. It is also ironic that Octavian talks of the softening and civilizing effect of women on the "fierce but uncouth" men as Rome rose to her greatness; but he himself will not be mollified by women in any way, as seen later in the same episode when Octavian puts his mother and sister under house arrest for their adulteries. ${ }^{17}$

In addition to Octavian, Antony's maleness is also compared and contrasted with that of Lucius Vorenus. At first the two men seem like complete opposites, other than the fact they share superb soldiering skills. Vorenus is stoic and adheres to old-fashioned morals, whereas Antony is decadent and pleasure-driven. But, as already mentioned, Vorenus recognizes that he and Antony share "a similar sickness," one he cannot quite name; but he knows it is sending them both on their way to tragic deaths. As Antony's power begins to decline, his outward maleness and Romanness is also brought into question with his dress and behavior. But he

17 Guilia Sissa, Sex and Sensuality in the Ancient World (New Haven and London: Yale University Press, 2008) 154, explains how mollita was not just connected with gender for the Romans, but with "culture, civility, and urbanity. Whereas the growth of the individual is from soft to hard, the evolution of societies goes in the opposite direction - from hard to soft." The inevitable tension between these opposite trajectories is evident in the Rome series too. 
also acquires an integrity of character and a stoic acceptance of his own tragedy at the end, much like Vorenus. As Antony and Vorenus row away from the burning ships on a small boat after the Battle of Actium, Antony declares: "All my life I've been fearful of defeat. But now that it has come, it's not near as terrible as I'd expected. The sun still shines, water still tastes good. Glory is all well and good, but life is enough, eh?" But faced with surrender later as he looks into the face of Cleopatra, Antony breaks down and cries. With tears rolling down his cheeks, he begs her to consider death because he will not "surrender or run and hide under bushes like hunted animals."

Importantly, it is Vorenus, not Cleopatra, who shares Antony's last moments when Antony decides to end his life quickly now that he thinks Cleopatra has gone ahead of him. Antony wants a Roman death and a good Roman sword with which to do it, which he borrows from Vorenus. He also asks Vorenus to hold the sword for him, as he remarks, looking around, that this is a "good place to die" because men who knew Alexander once stood there. When Antony bares his chest to receive the blade, we see that he has not grown physically soft. His male body is still beautiful in its virility. When Vorenus tells Antony that it has been an honor serving him, Antony is pleased: "Has it? Good, I hope so. Tell the people I died well. I died Roman." And he does. Antony's death is redemptive because of his recognition that his own failures have led him to his end. ${ }^{18}$ This is especially evident by the visual remembrance this death scene has with a much earlier scene in which Antony goes to Vorenus' house (at the request of Pullo who is worried that his friend cannot emerge from his grief over Niobe's death). As Antony stands up close to Vorenus, looking him in the face, he says, "No man is beyond redemption, Lucius, not even you." In Antony's death scene, the men face each other in the very same pose, reminding us of Antony's words whispered to Vorenus long ago. As Antony dies, he falls into Vorenus' arms, embracing him like a lover. Perhaps Antony, too, is not beyond redemption.

Symbolically this is represented when Vorenus recovers Antony's Roman manhood for him by immediately wiping off his Egyptian makeup. Then Vorenus puts the outfit of a Roman general on his leader before he props him up for public viewing. But Antony's masculinity has been transformed. There is a stark contrast between the brute soldier of the

18 Although Plutarch also pictures Antony as tragic, it centers around a much different tension: nobility of birth vs. moral degeneration. In Rome, Antony's nobility only emerges at the end. 
beginning of the first season of Rome, who seemed to have no thoughts beyond fighting and screwing, and the man we see in these last scenes, who cries, philosophizes about death, and even questions himself before acting. The softened Antony loses an empire but gains in character and irony as he is womanized, penetrated, and redeemed in death. The hardened Octavian gains an empire but loses his soul, and his sense of irony, as he is thoroughly ro-manized and iconized in imperial triumph in the last frames of the series. ${ }^{19}$

\section{Works Cited}

Butler, Judith. Bodies That Matter: On the Discursive Limits of "Sex" (London and New York: Routledge, 1993).

Corbeill, Anthony. "Dining Deviants in Roman Political Invective," in Judith P. Hallett and Marilyn B. Skinner, eds., Roman Sexualites (Princeton: Princeton University Press, 1997) 99-128.

Cyrino, Monica, ed. Rome, Season One: History Makes Television (Oxford: Blackwell, 2008). Hall, Donald E. Queer Theories (New York: Palgrave MacMillan, 2003).

Hallett, Judith P., and Marilyn B. Skinner, eds. Roman Sexualities (Princeton: Princeton University Press, 1997).

Joshel, Sandra R., Margaret Malamud, and Donald T. McGuire, Jr., eds. Imperial Projections: Ancient Rome in Modern Popular Culture (Baltimore and London: Johns Hopkins University Press, 2001).

Ker, Walter C.A., trans. and ed. Cicero: Philippics, Loeb Classical Library (Cambridge, MA: Harvard University Press, 1926).

Ormand, Kirk. Controlling Desires: Sexuality in Ancient Greece and Rome (Westport, Connecticut and London: Praeger, 2009).

Pelling, C.B.R., ed. Plutarch: Life of Antony (Cambridge: Cambridge University Press, 1988).

Perrin, Bernadotte, trans. and ed. Plutarch's Lives, Vol. IX, Loeb Classical Library (Cambridge, MA: Harvard University Press, 1920).

Ramsey, John T., ed. Cicero: Philippics I-II (Cambridge: Cambridge University Press, 2003).

Raucci, Stacie. "Spectacle of Sex: Bodies on Display in Rome," in Cyrino, ed., Rome, Season One (Oxford: Blackwell, 2008) 207-218.

Sedgwick, Eve Kosofsky. Epistemology of the Closet (Berkeley and Los Angeles: University of California Press, 1990).

Sissa, Giulia. Sex and Sensuality in the Ancient World (New Haven and London: Yale University Press, 2008).

Walters, Jonathan. "Invading the Roman Body: Manliness and Impenetrability in Roman Thought," in Hallett and Skinner, eds., Roman Sexualities (Princeton University Press, 1997) 29-43.

19 When his sister and mother ask whether he is joking when he proposes sending them to Alexandria to talk to Antony in Episode 9, Octavian comments, "I cannot remember the last time I made a joke." 



\title{
CLEOPATRA'S VENUS
}

\author{
Elisabeth Bronfen
}

Venus, taking her name from the Latin word for a gracefulness adept in exercising an alluring charm, came to be known as the "patron goddess of all persuasive seductions, between gods and mortals, and between men and women." ${ }^{\prime \prime}$ Seminal for the imaginary alignment Western culture, in turn, came to draw between Cleopatra VII, the last pharaoh of Ancient Egypt, and this goddess of seduction, is the way both Greek and the Roman mythology cast her as a representative of an ambivalent charm, combining erotic power with a capacity for deception. Although Venus was first and foremost conceived as an emblematic figure for the feminine procreation necessary for the continuity of the community, the mythopoetics of antiquity sometimes also places her in proximity to Hesiod's first woman, Pandora, whose curiosity released a plethora of destructive forces into the world. With the snake as one of her attributes, Cleopatra, in turn, was repeatedly painted to resemble Eve, the first woman of JudeoChristian mythopoetics, whose curiosity, also, was made responsible for the loss of paradise and the introduction of death and sin into human existence. ${ }^{2}$ There is, however, a further similarity at issue between these two feminine embodiments of deceptive sexual allure, namely, the lack of agreement on their historical origins. Greek literature in particular often claimed that Venus came from the East, while Cleopatra, whose family was of Greek origin, self-consciously styled herself as Eastern royalty, only to have herself declared a living embodiment of the Egyptian goddess Isis. ${ }^{3}$ What Venus and Cleopatra thus also share is the way in which they

1 See John Scheid's entry on "Venus" in Simon Hornblower and Antony Spawforth, eds., The Oxford Classical Dictionary 3 (Oxford: Oxford University Press, 1996) 1587.

${ }^{2}$ For documentation on the visual analogies between Cleopatra and both Eve and Venus, see the Musée Rath's exhibition catalogue, Claude Ritschard and Allison Morehead, eds., Cléopâtre dans le miroir de l'art occidental (Genève: Musée d'art et d'histoire, 2004), March 25 to August 1, 2004.

3 See Stacy Schiff, Cleopatra: A Life (New York: Random House, 2010) for the most recent discussion of the ambivalent mythic narratives surrounding this historical figure. See also Prudence J. Jones, ed., Cleopatra: A Sourcebook (Norman: University of Oklahoma, 2006) for a representative selection of texts dealing with her hybrid representation, as well as Sabine Kubisch and Hilmar Klinkott, Kleopatra. Pharaonin. Göttin. Visionärin (Stuttgart: Konrad Theiss Verlag, 2011) especially for the way it foregrounds her political role. 
were conceived as culturally hybrid figures. Both were worshipped within a cultural domain to which they were also declared to be foreign. Their cultural uncanniness continues to be part of their seductive power, allowing them to bridge the Western world with its Oriental influences.

Indeed, if their allure is familiar and strange, it is so powerful perhaps precisely because it is both. Venus was a double-voiced goddess in that she was worshipped by girls about to be married, who hoped for successful sexual reproduction. Yet she was also the protectress of prostitutes, whose profession depended on sexual charms. Although a wide range of attributes came to be ascribed to Venus, for the purpose of my discussion of the way Cleopatra was reconfigured along the lines of this love goddess, this essay will focus only on her significance as a divine embodiment of a femininity, especially in the literary tradition prominently associated with Mars, the war god of antiquity. While in mythopoetic texts, the martial power of Venus/Aphrodite pertains primarily to a battle of the sexes, it is worth recalling that in the mythic story of the Judgment of Paris, she is the one who wins the competition against Hera and Athena, and in so doing is partially responsible for the outbreak of the Trojan War. The conjunction between sexual allure and war, in turn, becomes more prominent regarding Cleopatra, who quite explicitly did not shirk from battle and for whom the role of warrior queen supported rather than contradicted her impersonation of a love goddess. Indeed, the cultural afterlife of Cleopatra's Venus this essay proposes is grounded on the way this last Egyptian pharaoh thrives on a transitional hybridity in more than one sense. Both in the literary and the visual representations we have of Cleopatra, we find a sovereign who crosses not only her Greek heritage with her Egyptian symbolic political mandate. Nor is she simply reduced to the feminine embodiment of an Oriental allure that came to successfully entrap two Roman war heroes. She is also conceived as a transitional figure in the sense that her demise marks the end of a political dynasty, serving to consolidate the hegemony of Roman rule.

The image most readily associated with Cleopatra is that of her beautiful corpse, either exposed as a naked body, with a snake at her breast, or placed on public display in full funeral regalia. Over her dead body, Octavius came to celebrate his political ideology by erecting a monument to precisely the embodiment of a foreign but seductive culture he had vanquished and sacrificed. ${ }^{4}$ Indeed, it is important to remember that we

${ }^{4}$ For a discussion of feminine sacrifice as constitutive within foundation myths, see Elisabeth Bronfen, Over Her Dead Body: Death, Femininity and the Aesthetic (New York: Routledge, 1992). 
know very little about the actual historical person Cleopatra; we have little factual evidence of what she looked like. Instead, most research on her cultural afterlife draws attention to the way she functions as an enigmatic figure to whom we have access only through the long tradition of posthumous representations she has been able to call forth. Her affective effect is on the level of memory and representational traces. Even the coins and sculptures of her may well say more about how she wanted herself to be viewed and remembered by posterity than what she actually looked like. ${ }^{5}$

Equally seminal is the fact that her cultural survival in the image repertoire of western literature, painting, and film has its beginnings in Octavius' propaganda, whose purpose was fairly straightforward. To salvage Antony's name, it was of utmost importance to paint his warrior queen as the wicked, morally depraved, oriental, lascivious whore. The Roman authors on whose texts all subsequent reconfigurations necessarily must rely paint her as the femme fatale in a battle between valiant Roman politicians, for which, having successfully brought about the downfall of his rival, Mark Antony, Octavius needed his Egyptian queen to take the full blame. Since the medieval period, each century, as Lucy Hughes-Hallett documents, has accentuated this story differently, and yet we find with an astonishing persistence the rhetorical gesture of feminine sacrifice. ${ }^{6}$ The visual and narrative celebration of Cleopatra's beautiful corpse is coterminous with the successful destruction of a sexual charm attributed to the East. At the same time, this belated mythic narrative seeks to screen out the manner in which Cleopatra's erotic allure was already during her lifetime coupled with political power and, as such, posed an actual political threat to the government in Rome. If in its foundation myth Augustan propaganda maligns her, it obliquely discloses its own desire and need for a coverup. At issue is precisely the duplicitous rhetoric of fetishism at work. By erecting a monument to the vanquishing of this last Egyptian pharaoh, what came to live on in the cultural imaginary of the West is precisely the myth of an oriental femme fatale, commemorating a feminine allure that uncannily straddles the political and the public. Indeed, it is fruitful

5 For feminist research seeking to reconstruct and critically reflect on this history of belated transmission, see Mary Hamer, Signs of Cleopatra (London: Routledge, 1993). For archeological reconstructions of her representations, see the catalogue from the Brooklyn Museum's exhibition of Cleopatra's Egypt: Age of the Ptolemies (Mainz: Philipp von Zabern, 1989) as well as Susan Walker and Peter Higgs, Cleopatra of Egypt: From History to Myth (Princeton: Princeton University Press, 2001).

6 Lucy Hughes-Hallett, Cleopatra: Histories, Dreams and Distortions (New York: Harper \& Row, 1990). 
to recall that had Cleopatra not committed suicide, Octavius would have put her on display in his victory parade through Rome. Given her suicide, he could instead only include a statue of her dead body, with the fatal serpent at her naked breast, in his procession.

If, then, Cleopatra is an empty figure (a historical " $\mathrm{X}$ "), whom we have come to know only belatedly through her subsequent representations, to reconstruct her involves what Mieke Bal calls doing "preposterous" history. We need to reimagine her as the effect of the recyclings through which she has had such an affective cultural effect. ${ }^{7}$ We need to look back at her from the position of a belated viewing, through the lens of representations that have come to make up her myth. While Venus is not the only iconographic point of reference in the plethora of paintings that have come into circulation since the late medieval period, this essay will focus on Cleopatra's posthumous staging as a duplicitous love goddess because this visual trajectory allows one to uncover more than the continuation of the misogynist tradition Octavius' propagandists inaugurated, a tradition in which she first and foremost survives as the fatal love goddess who bewitched two valiant Roman war heroes. Instead, to focus on Cleopatra's Venus allows one to foreground the issue of an ambivalent feminine selfempowerment, able to seduce both Mark Antony and the audience, as Shakespeare's reconfiguration of Plutarch's calculating queen intones. As Catherine Belsey notes, his "Cleopatra is like a work of art, and like Venus, goddess of love; she is like a picture of Venus, since fancy, or fantasy, can improve on nature; and yet she outdoes all these possibilities, which is to say, she outdoes divinity, nature and art." 8 My own critical point is that even if we remain within the domain of fancy and fantasy, with each century reimagining a Cleopatra befitting its cultural needs, it is possible to redraw the lines of her cultural survival so as to foreground her malleable power rather than her fatality.

The most explicit connection between Cleopatra and Venus involves the way she appeared as a goddess in Rome. As Sally-Ann Ashton notes, the first reference "is to a statue in the temple of Venus Genetrix, which was said to have been dedicated by Julius Caesar but which, sadly,

7 See Mieke Bal, Quoting Caravaggio. Contemporary Art, Preposterous History (Chicago: University of Chicago Press, 1999). Other cross-associations exist with Lucretia, in which the dagger takes the place of the snake; with Dido lamenting the Roman lover who abandoned her; and with Christ's dead body, serving as the object of a collective gaze of mourning.

8 Catherine Belsey, "Cleopatra's Seduction," in Terence Hawkes, ed., Alternative Shakespeares (London: Routledge, 1996) II, 45. For a collection of the texts on which her myth in Western culture is based, see Jones, Cleopatra: A Sourcebook. 
does not survive." ${ }^{\prime 2}$ The fact that we have only a description of this statue by Appian in his Civil War turns this first example into a perfect starting point for a discussion of how Cleopatra's "preposterous" Venus exists only as a composite of cultural traces through which we can reconstruct her seductive force belatedly. Other historical sources recall how, in her lifetime, Cleopatra, brilliant at all politically tuned self-staging, had used her luxurious festivities in Alexandria so as to recast her relationship with Mark Antony in term of Venus reveling with Mars. Indeed, around 1650, Leonhard Kern produced two ivory statues posing as in a joint dance. Although the title given is "Antony and Cleopatra," the couple could just as easily recall images of Venus and Mars (or Eve and Adam for that matter). Seminal about this iconographic casting is that while Venus functioned as a war goddess only in the battlefield of love, Cleopatra was a warrior queen for whom the self-fashioning as love goddess was not in contrast to but part and parcel of her self-fashioning as a ruthless military strategist (even if the choice of naval battle at Actium would ultimate cause the utter destruction of her forces). The conceptual alignment between sexual allure and war finds its acme, of course, in the twentieth-century pin-up, with Marilyn Monroe emerging as the most resilient example of a love goddess whose beauty served to screen out the horror and actual carnage of battle. Yet in this spirit we also find one of Hollywood's cinematic reconfigurations of Cleopatra's myth playing to the erotic allure of a call to battle. The penultimate sequence of Gabriel Pascal's film version of Bernhard Shaw's Caesar and Cleopatra sets in with a close-up of Vivien Leigh's face. A lap dissolve moves to the scenes of battle her court intrigue has prompted - initially the valiant march of Caesar's bombastic army, with him at the head and his Egyptian queen by his side, then a series of vignettes documenting the battle in which he successfully vanquishes the enemy. Yet even as the camera tracks the flight of the few survivors of this campaign, it tarries with the causalities. We see the corpses of proud Roman soldiers lying in the sand, their shields and spears abandoned.

One is, again, prompted to recall how, in the mythic narrative of the Judgment of Paris, the promise Venus gives to the young Trojan prince who declared her to be the most beautiful of the three goddesses, ultimately came to launch a thousand ships. Indeed, the final sequence of the film culminates in a chiasmic return to a superimposition of Cleopatra's beautiful face over the remnants of war's carnage. We might also, however,

9 Sally-Ann Ashton, Cleopatra and Egypt (Oxford: Blackwell Publishing, 2008) 143. 


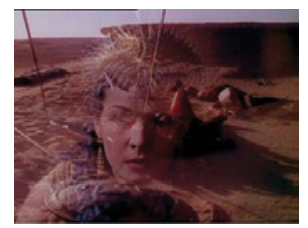

Vivien Leigh in Caesar and Cleopatra (1945).

recall that this film was released in 1945, and thus obliquely referenced global military destruction of the second World War. Vivian Leigh's star image covers over what it also alludes to. We first see her again in a closeup, staring into space in wide-eyed horror, and then she too dissolves into a shot of the sphinx while the voice-over, in reference both to the pharaoh she is playing and the ancient sculpture referring to another powerful feminine force, explains, "part brute, part woman, part god." The sequence ends with a monumental celebration of Caesar's military triumph and his departure for Rome. Although Vivian Leigh is perhaps the least well-known of Hollywood's film icons to bring Cleopatra to the screen, her performance draws a seminal ambivalence to our attention. What the mise-en-scène, along with this star presence, brings to the screen is not the child queen Shaw's misogynist drama foregrounds. By the end of World War II, Vivian Leigh had become a global celebrity owing to her performance of Scarlett O'Hara in Gone with the Wind, a different homefront war heroine. Against the play's script, her star allure brings this Hollywood Cleopatra closer to Shakespeare's vision, suggesting that as a love goddess, this pharaoh - and this movie star - have an agenda of their own. The beautiful face, out of which a triumphant military campaign along with its dead emerge and to which images of this destruction return, is shown to represent a woman who uses the battle between two opposing masculine fronts to perpetrate a different, more enigmatic political fantasy. In Gabriel Pascal's film, the deception ascribed to Venus involves not only sexual charm but also the desire for political power this screens out only imperfectly.

We might thus fruitfully speak of three distinct thematic domains that come together over Cleopatra's Venus. The first involves the issue of celebrity as a modern form of political charisma. The second points to the deployment of theatrical spectacle to support political power, while the third involves imaginary projection as a tool not only for subsuming femininity into masculinist self-representations of political power but also serving articulations of feminine self-negotiation. To illustrate the first point, let us recall that Vivian Leigh was not the first star to play Cleopatra. Rather, she continues a long line of female performers who passionately identified 
with the Egyptian pharaoh who, herself, had performed the goddess Isis for the edification of her subjects, declaring herself to be a living embodiment of this deity. The chain of projections is complicated by the fact that while celebrity studies has argued that we identify with stars to give coherence to our lives, stars have themselves identified with mythic figures to give coherence to their celebrity image. In the case of Cleopatra, a wide range of theater actresses, opera singers, writers, and movie stars have chosen her as their figure of identification, with Sarah Bernhardt as perhaps the most notorious. Not only is her performance of Cleopatra as a reconfiguration of Venus documented by a plethora of photographs taken of her while she was enacting this role for diverse theater productions; Bernhardt also had Alfons Mucha and Georges Fouquet devise a snake bracelet for this particular role, while both Gustave Moreau and Georges Antoine Rochegrosse painted her as Cleopatra. ${ }^{10}$ If each age reconceives this enigmatic historic figure to befit its cultural needs, the preference this prominent actress showed for the role of Cleopatra not only places the Egyptian queen into a paradigm of modern femininity; it also self-consciously underscores her intent in reconfiguring the far more passive femme fatal of the masculinist tradition of Symbolist painting to befit her own celebrity image. Bernhardt, known for a carte de visite showing her sleeping in her coffin, repeatedly used the icon of feminine death to reassert her own vitality as an artist. If she has herself painted as Cleopatra, the identification is not with an oriental prostitute and the evil seductress of Roman warriors. It is with a feminine figure of political power whose most prominent weapon was her theatrical charm.

Regarding the second domain, the conjunction between theatrical spectacle and political power, another aspect to Cleopatra's charm emerges. Hybridity is again at issue in the double divinity ascribed to her - her own decision to have herself worshipped as a mortal embodiment of the Egyptian goddess Isis, and Caesar's commemoration of her in a temple honoring Venus. Both mark a political strategy that has left its traces in Cleopatra's cultural survival. Along with the staging of her corpse there is the infamous scene during one of her lavish banquets, when she is said to have dissolved one of her most valuable pearls in a cup of vinegar so that by drinking it, she could prove to Mark Antony her proclivity toward extravagance. In Pliny the Elder's Natural History we read: “There were two pearls, the largest in history; and Cleopatra, the last of the Queens of Egypt, owned them both... the servants placed before her only a single

10 See Claudia Balk, Theatergöttinnen. Inszenierte Weiblichkeit. Clara Ziegler - Sarah Bernhardt - Eleonora Duse (Basel: Stroemfeld Verlag, 1994). 
cup of vinegar, the sharpness and power of which disintegrates pearls to pulp. She was wearing in her ears that especially unusual and truly unique work of nature. And so, with Antony eagerly anticipating what she would do, she took one off and dropped it in, and when it was wasted away she swallowed it."11 Finally, we have her famed journey up the Nile. Conjecture has it that she staged this to perform her proximity to the customs of her Egyptian subjects. Regardless of the actual intention, in hindsight it recalls the political spectacle of an equally hybrid Queen, namely Elizabeth I, who was known to perfect the theatrical staging of her body so as to perform her political sovereignty. The summer progresses with which she toured England at an enormous expense served to bodily reconfirm the bond between this early modern queen, who herself emerged from a civil war and was beset by conspirators. Elizabeth I is a love goddess in her own right, even if it is the Virgin Queen and not Venus whom she chose as her iconographic reference. The point of analogy between her and Cleopatra is the the hybridity their feminine queenship puts on display, appropriating a masculine position of power by overtly staging feminine charm. Indeed, both allow us to rethink the gendering of a spectacle of political power, given that Elizabeth I and her Egyptian predecessor perform a fusion of natural and symbolic body, rendering complex the notion of the King's two bodies. Their physical substance declares their political power, while the theatrical spectacle serves as the performance of this sovereignty. Most importantly, what is foregrounded is not fatality but the ability to appropriate and reconfigure themselves within a symbolic system of interpellation. ${ }^{2}$

Once we focus on Cleopatra as a figure of public allure, a third conjunction between celebrity, politics, and spectacle emerges. More than any other mythic or historic queen, she came to be a screen of projection not only for male artists, negotiating the ambivalence surrounding Venus' sexual charm, but also for society women, seeking to put the actual power of their prosperity on display. Along with the enormous visual archive of public performers playing the role of Cleopatra in drama, opera and film, we have paintings and photographs of society women dressing up

11 Quoted in Jones, Cleopatra, 107-108.

12 For a discussion of the theatricality of political power in the English Renaissance, see Louis Montrose, The Subject of Elizabeth: Authority, Gender, and Representation (Chicago: University of Chicago Press, 2006). For a discussion of Elizabeth I as a celebrity icon, see Elisabeth Bronfen and Barbara Straumann, "Political visions: the two bodies of Elizabeth I," in Liz Oakley-Brown \& Louise J. Wilkinson, eds., The Rituals and Rhetoric of Queenship: Medieval to Early Modern (Dublin: Four Courts Press, 2009). 
as Cleopatra for costume balls or photo sessions, turning their bourgeois salon into a stage. In this visual archive, many of the women portrayed are anything but love goddesses. The fact that they often choose to sit on a throne illustrates how their identification with the infamous seductress of antiquity was neither with her extravagance (the sacrifice of her most valuable pearl), nor with an eroticization of her death (the snake at her naked breast). Rather, at issue is an appropriation of her allure as royalty, of her power as a public figure of fascination and adoration. It is, of course, not surprising that we find far fewer representations of Cleopatra as a powerful political ruler, patron of the arts, and author of several book in the archive of Western painting and literature. More surprising is the fact that society women of the 18th and 19th century served to bring this other face into circulation by virtue of their performative recitation.

When one turns to the traditional image repertoire of Cleopatra, one is, in fact, struck by the exchangeability of attributions of feminine sexual allure which repeatedly brings her in close proximity to Venus. In a painting of her dying by Jan van Scorel (1520), the presence of the snake wrapped around her right wrist alone indicates that this is not a painting of the love goddess herself, even while we have an oblique reference to sexual self-satisfaction, with her left hand disappearing just beneath her crotch. Michelangelo's portrait (1533), in turn, emphasizes the eroticism of her death, with the serpent's head lovingly enfolding her naked left breast, even while producing the hybridity between beast, woman, and goddess which the voice-over comment in Gabriel Pascal's film invokes. The self-pleasure we find depicted in many of the classic paintings suggests that Cleopatra was conceived as the agent of her own desire, even if this is a fatal self-enjoyment. Some of the most dramatic depictions of selfempowerment can be found in the paintings by Artemisia Gentileschi, whose "Cleopatra" (1620) moves into the league of Christian martyrs, with her head bent backwards as though ecstatically enjoying her own selfexpenditure. Looked at obliquely, however the snake her queen is holding in her right hand could be seen to signify the paint brush. Her Cleopatra's dying allure can be construed as a comment on the act of a woman, painting herself into a masculine tradition of feminine self-sacrifice.

This image repertoire has found its most pointedly cultural survival in the arena of 2oth century celebrity culture, where, however, the issue of feminine self-empowerment is everything but oblique. More than any other Hollywood actress, Theda Bara, the most notorious of all silent cinema vamps, has come to be closely aligned with her performance of 


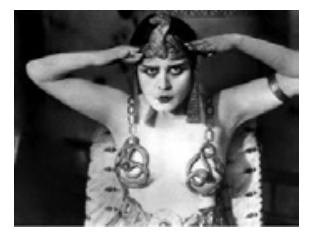

Theda Bara in Cleopatra (1917).

the last Egyptian pharaoh. ${ }^{13}$ Her Cleopatra (1917) set both the visual and the dramatic tone for all subsequent film versions, even though, like the statue of Venus in Rome, the actual footage of the film is now all but lost. Befitting the wager of this essay, we have, instead, a plethora of film stills, attesting as visual traces to this iconic cinematic performance. In these we find an appropriation of the orientalist fantasy of symbolist painting productively fused with the sexual power of the modern women. Even while Theda Bara picks up on a tradition that puts the exposed female body on display for the voyeuristic pleasure of a masculine spectator, she adds something distinctively new, namely an aggressive self-enactment which would again come to be censored by the Hays Production Code by the mid1930s. What we see in these film stills is a female star, identifying herself with the power of a previous political celebrity, unabashedly putting her sexual allure on display to celebrate a charm utterly devoid of all fatality. Instead, as a figure of projection, Theda Bara's Cleopatra came to allow all subsequent film actresses to reflect on their own cultural and economic force. Successful hybridity is taken to a different level, even if Theda Bara herself never made the move into sound film. The eroticism she embodies is joyfully ambivalent, crossing an invitation to voyeurism with pleasurable exhibitionism. She perfectly brings into dialog the Hollywood star system's commodification of the actress and her own idiosyncratic self-projection.

While Mae West is perhaps the more obvious continuation of such audacious female sexuality on screen, Claudette Colbert's rich baritone voice gives a particularly American tone to the Egyptian pharaoh in Cecil B. DeMille's Cleopatra of 1934. Her performance was to become the epitome of 1930 glamour, prompting her female audience to buy cosmetic products that used Cleopatra on their label, while the film icon became the subject of Reginald Marsh's painting A Paramount Picture (1934). With two ordinary women posed in close proximity to the glamour picture on the poster, the painting captures this process of consumer identification. At the same

13 In general, see Maria Wyke, The Roman Mistress: Ancient and Modern Representations (Oxford: Oxford University Press, 2002) 244-320. 


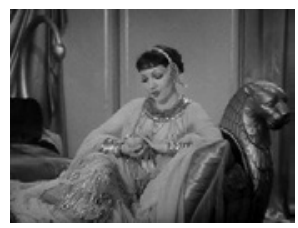

Claudette Colbert in Cleopatra (1934).

time, given Colbert's recycling of Theda Bara's costume, one can also not help but see her performance as a repetition of an earlier cinematic style. There is, however, a far more astonishing postmodern turn to Theda Bara as Cleopatra. For the December 1958 issue of Life, Richard Avedon photographed Marilyn Monroe in a series of scenes in which she impersonates five cinema enchantresses, who, as the accompanying text states, "embody the fancies men dream by - the places thy might have visited with her, music danced with her, suppers shared with her." The text to the two photographs in which Monroe poses as Theda Bara's Cleopatra, explains: "the movie's first heavy-breathing temptress and the original vampire was Theda Bara - and this is Marilyn Monroe as this most famous of all vamps. In A Fool There Was and 40 other films made between 1915 and 1921, Theda played the heartless siren who toys with her men, ruins them and tosses them aside. Her greatest line of dialogue was 'Kiss me, my fool' - and millions of men recklessly wished that they could be her fool, just for one kiss. She puzzled Marilyn, who, as she fell into Theda Bara's famous Cleopatra pose, giggled, 'What am I supposed to be thinking of?'”

What we might think about is the issue of recycling at stake when a star turns herself into a previous star's incorporation of an ancient political star. Warhol's silk screens of Marilyn Monroe self-consciously put on display the fading such seriality implies. Yet in Avedon's photo shoot we also find an idiosyncratic reconfiguration of the canon, with Monroe writing herself into the pantheon of famous seductresses. Of course, the Hollywood star who is most readily associated with Cleopatra today is Elizabeth Taylor, whom Warhol painted in this role. During her monumental arrival in Rome together with the son she has born Caesar an enormous black sphinx serves as her carriage. Cleopatra is dressed entirely in gold so as to visualize her statuary quality, and yet, after Caesar has smiled to her and beckoned her to approach, she does not merely bow before him. Liz Taylor adds her own mark of audacity - she winks at the Roman sovereign. In this reenactment of political spectacle, banking on Cleopatra's alliance with the public stagings of queenship, a private love story has come to be crossed with national interests, bringing the East into the heart of the 


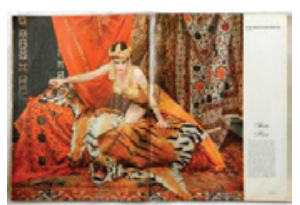

Marilyn Monroe as Cleopatra.

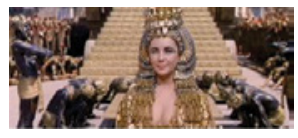

Elizabeth Taylor in Cleopatra (1963).

West. Yet what Taylor's performance also does is fuse Cleopatra's embodiment of divinity with an insistence on the singularly human, the mother bringing to the father the fruit of their love, under the protection of Venus. Ambivalence is again inscribed in the love goddess iconography Mankiewicz's film self-consciously alludes to. There is nothing fatal, passive or fetishistic about this self-enactment. Instead, we are meant to enjoy Liz Taylor, a global icon of 6os glamour, performing her own status as a powerful female film icon. The celebration of a love goddess's political sovereignty is mapped onto the bombastic celebration of a Hollywood star.

As with Vivian Leigh's performance, it is again fruitful to note the historical context from which this film, released in 1963, emerges. Unable to compete against the rising power of television, Hollywood had recourse to epic films to celebrate its own monumental power one last time, as though cognizant of its imminent demise. Spectacle and seduction are taken to an extreme, with Taylor's wink adding a moment of irony, of self-conscious play with the tradition of Cleopatra's afterlife in visual culture. This wink is also an homage to a moment of transition. Liz Taylor would continue as a film star, even if the fated Egyptian pharaoh has remained the role with which she continues to be identified. The classic Hollywood system did not survive; indeed, Fox studios would ultimately collapse under the financial strain of producing Cleopatra. In hindsight one can detect a poignant analogy to the demise of the historical Cleopatra's reign. Her monumental reimagination on the Hollywood screen marks the end of the very studio system to whose own monumentality this epic film speaks. While Marilyn Monroe, the most resilient of all Hollywood love goddesses, never played Cleopatra apart from her photo session with Avedon, she, too, is connected to this fated filming. Her role involves a competition that once more recalls the Judgment of Paris, so seminal to the notoriety of Venus herself. In her 


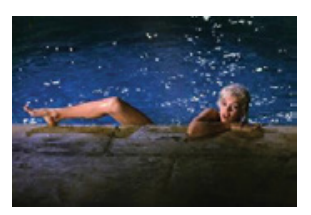

Marilyn Monroe in Something's Got to Give (1962).

case, however, it was the men of the press who were called upon to decide which of the screen goddesses - Monroe or Taylor - was the most fair.

Monroe was having trouble with the production bosses of Fox studios during the shooting of what was to become her last unfinished film, Something's Got to Give. She had repeatedly missed coming to the set and would ultimately find herself embroiled in a law suit. Jealous over the attention Liz Taylor was getting in the media for her spectacular appearance as Cleopatra, as well as the stormy romance with her co-star Richard Burton, Monroe came up with a ruse worthy of Cleopatra's own intrigues against her political competitors. She invited the press to the shooting of the infamous scene in which she swims naked in her estranged husband's backyard pool. The photographs, which successfully displaced Liz Taylor from the covers of the high gloss magazines attest to a sexual audacity coupled with an unbridled self-enjoyment that - again in hindsight - mark her real tribute to Theda Bara and to the ancient queen both film icons helped resuscitate for the twentieth century.

\section{Works Cited}

Ashton, Sally-Ann. Cleopatra and Egypt (Oxford: Blackwell Publishing, 2008).

Bal, Mieke. Quoting Caravaggio. Contemporary Art, Preposterous History (Chicago: University of Chicago Press, 1999).

Balk, Claudia. Theatergöttinnen. Inszenierte Weiblichkeit. Clara Ziegler - Sarah Bernhardt Eleonora Duse (Basel: Stroemfeld Verlag, 1994).

Belsey, Catherine. "Cleopatra's Seduction," in Terence Hawkes, ed., Alternative Shakespeares (London: Routledge, 1996) II, 45.

Bronfen, Elisabeth. Over Her Dead Body: Death, Femininity and the Aesthetic (New York: Routledge, 1992).

Bronfen, Elisabeth and Barbara Straumann. "Political visions: the two bodies of Elizabeth I," in Liz Oakley-Brown \& Louise J. Wilkinson, eds., The Rituals and Rhetoric of Queenship: Medieval to Early Modern (Dublin: Four Courts Press, 2009).

Brooklyn Museum of Art. Cleopatra's Egypt: Age of the Ptolemies (Mainz: Philipp von Zabern, 1989).

Hamer, Mary. Signs of Cleopatra (London: Routledge, 1993).

Hughes-Hallett, Lucy. Cleopatra: Histories, Dreams and Distortions (New York: Harper \& Row, 1990).

Jones, Prudence J., ed. Cleopatra: A Sourcebook (Norman: University of Oklahoma, 2006). 
Kubisch, Sabine and Hilmar Klinkott. Kleopatra. Pharaonin. Göttin. Visionärin (Stuttgart: Konrad Theiss Verlag, 2011).

Montrose, Louis. The Subject of Elizabeth: Authority, Gender, and Representation (Chicago: University of Chicago Press, 2006).

Ritschard, Claude and Allison Morehead, eds. Cléopâtre dans le miroir de l'art occidental (Genève: Musée d'art et d'histoire, 2004), March 25 to August 1, 2004.

Scheid, John. "Venus," in Simon Hornblower and Antony Spawforth, eds., The Oxford Classical Dictionary (3rd ed.; Oxford: Oxford University Press, 1996).

Schiff, Stacy. Cleopatra: A Life (New York: Random House, 2010).

Walker, Susan and Peter Higgs. Cleopatra of Egypt: From History to Myth (Princeton: Princeton University Press, 2001).

Wyke, Maria. The Roman Mistress: Ancient and Modern Representations (Oxford: Oxford University Press, 2002). 


\section{MYTHOLOGICAL ANCIENTS}





\title{
OVER HIS DEAD BODY: MALE FRIENDSHIP IN HOMER'S ILIAD AND WOLFGANG PETERSEN'S TROY (2004)
}

\author{
Andreas Krass
}

In the literary history of male friendship, a particular discursive scenario is ubiquitous. As one friend has just died, the other laments about his terrible loss. This is the case with Achilles \& Patroclus in Homer's Iliad as well as David \& Jonathan in the Old Testament, Aeneas \& Pallas in Vergil's Aeneid, Laelius \& Scipio in Cicero's On Friendship, and Michel de Montaigne \& Étienne de la Boétie in Montaigne's Essay on Friendship. ${ }^{1}$ It seems that male friendship needs a discursive license to be legitimized as a topic in literary texts. A man passionately expressing his love for another man will not be disparaged if the person he talks about is dead and if his thoughts and feelings are uttered in the mode of grief. The taboo of judging someone who has lost his closest friend excels the taboo of what is called "homosexuality." In my article, I would like to show how this discursive arrangement works by the example of "one of the most celebrated figures in the legends of Greek mythology," i.e., Achilles and his friend Patroclus. ${ }^{2}$ By comparing the first (Homer's Iliad) and - for the time being - latest (Wolfgang Petersen's Troy) major account of their story, I will analyze the different ways in which male friendship is dealt with in antiquity and modernity. ${ }^{3}$

${ }^{1}$ Cf. Andreas Krass, "Männerfreundschaft. Bündnis und Begehren in Michel de Montaignes Essay De l'amitié," in Andreas Krass and Alexandra Tischel, eds., Bündnis und Begehren. Ein Symposium über die Liebe, Berlin 2002 (Berlin: Geschlechterdifferenz und Literatur, 2002) 127-141.

2 Dorothea Sigel, "Achilles," in The New Pauly, Brill Online, June 29, 2010, accessed November 25, 2011.

${ }^{3}$ For the medieval discourse on Achilles and Patroclus, see Andreas Krass, "Achill und Patroclus. Freundschaft und Tod in den Trojaromanen Benoîts de Sainte-Maure, Herborts von Fritzlar und Konrads von Würzburg," in Zeitschrift für Literaturwissenschaft und Linguistik 114 (1999) 66-98. For filmic studies, see Martin M. Winkler, ed., Troy: From Homer's Iliad to Hollywood Epic (Malden, MA: Blackwell, 2007); and Kostas Myrsiades, ed., Reading Homer: Film and Text (Madison, NJ: Fairleigh Dickinson University Press, 2009). 
The Ancient Tradition:

From Homer's Iliad to Aeschines' Against Timarchus

In his groundbreaking study, Greek Homosexuality (1979), Kenneth J. Dover examines literary and pictorial records of sexual relationships between men in Greek antiquity. ${ }^{4}$ The story of Achilles and Patroclus as portrayed by Homer, Aeschylus, Plato, and Aeschines is, among many others, one of the most prominent instances. Like John Boswell in his famous study, Christianity, Social Tolerance, and Homosexuality: Gay People in Western Europe From the Beginning of the Christian Era to the Fourteenth Century (1980), Dover does not hesitate to apply the term "homosexuality" to premodern narratives and persons. ${ }^{5}$ From today's perspective it seems inadequate to do so since every epoch and culture have their own discourses on erotic relationships between persons of the same gender. Therefore this article intends to examine the precarious border between male friendship and sexuality rather than ask whether or not Achilles and Patroclus were "homosexuals."

\section{a) Brothers-in-arms: Homer}

The story of Achilles and Patroclus is told in the second half of the Iliad. ${ }^{6}$ Because Achilles has refused to participate any longer in the siege of Troy, Patroclus asks Achilles to lend him his weapons so he can fight against the enemy instead. Achilles agrees, and while wearing his armor, his fellow warrior and friend Patroclus along with the other Greek soldiers succeed in pushing the Trojans back to their ramparts. Apollo, however, favoring the Trojans, unexpectedly strikes Patroclus from behind. Weakened by this supernatural strike, Patroclus falters, is defeated, and is ultimately killed by Hector. The latter steals the armor Patroclus is wearing and puts it on. When Achilles is told that his friend is dead, he mourns him and swears to take revenge. Even unarmed, he manages to retrieve Patroclus' body from the battlefield. His mother, the nymph Thetis, asks Hephaes-

4 Kenneth J. Dover, Greek Homosexuality (rev. ed.; Harvard University Press, Cambridge, Massachusetts 1989); cf. Elke Hartmann, "Homosexuality," in The New Pauly, Brill Online, accessed November 25, 2011; B.R. Burg, ed., Gay Warriors, A Documentary History from the Ancient World to the Present (New York: New York University Press, 2002) 5-26.

5 John Boswell, Christianity, Social Tolerance, and Homosexuality: Gay People in Western Europe from the Beginning of the Christian Era to the Fourteenth Century (Chicago/London: 1980); Boswell also wrote about Achilles and Patroclus: "Battle-Worn: Gays in the Military 300 B.C.," in The New Republic 208 (May 1993) 15-18.

6 Homer, The Iliad (trans. Robert Fagles; New York: Penguin Classics, 1990). 
tus, the god of fire and metalworking, to forge a new armor for her son. On the following day she gives this new armor to Achilles and promises to prevent Patroclus' body from decaying. Wearing his new armor, Achilles fights a duel against Hector, who is still wearing Achilles' armor, and kills him. This avails Achilles and the Greeks the belated opportunity to lament Patroclus' death. At night the ghost of the deceased friend appears and demands of Achilles to expedite his funeral. The next morning Patroclus' body is cremated and his ashes are collected. Achilles, still furious about his friend's death, derides Hector's dead body and drags it around the tomb again and again.

Homer refrains from ascribing a sexual relationship to Achilles and Patroclus. Yet he portrays their friendship as highly passionate. In the first lines of his poem he introduces Achilles as a warrior driven by strong feelings (1.1-2):

Rage-Goddess, sing the rage of Peleus' son Achilles murderous, doomed, that cost the Achaeans countless losses.

At the outset Achilles' rage - "the leitmotiv of the Iliad" - is directed towards Agamemnon for kidnapping Briseis, one of his female slaves and lovers. ${ }^{7}$ The death of Patroclus marks a significant turning point. Now, Achilles' anger is redirected towards Hector for killing his friend. As Jan Stenger points out, the close connection between Achilles' wrath and Patroclus' fate "is probably a creation of the poet of the Iliad." 8 When Achilles rejoins the war, he intends to take revenge for his beloved friend rather than defend the Greeks. Rage and love seem to be two sides of the same coin.

How deeply the two brothers-in-arms love each other first becomes clear when Patroclus approaches Achilles with the request to send him out in his stead. Patroclus bursts into tears and Achilles feels deeply sorry for his friend (16.1-12):

So they fought to the death around that benched beaked ship as Patroclus reached Achilles, his great commander, and wept warm tears like a dark spring running down some desolate rock face, its shaded currents flowing. And the brilliant runner Achilles saw him coming, filled with pity and spoke out winging words: "Why in tears, Patroclus?

7 Dorothea Sigel, "Achilles."

8 Jan Stenger, "Patroclus," in The New Pauly, Brill Online, accessed November 25, 2011. 
Like a girl, a baby running after her mother, begging to be picked up, and she tugs her skirts, holding her back as she tries to hurry off - all tears, fawning up at her, till she takes her in her arms...

That's how you look, Patroclus, streaming live tears."

The intimacy of their friendship is compared to the close relationship of a mother to her daughter. In this ironical but nonetheless telling attribution of gender roles, Patroclus is compared to a girl, even though Homer elsewhere clearly portrays him as senior to Achilles. ${ }^{9}$ By effeminizing and emotionalizing the two friends, Homer indicates on a symbolic level that they are not only warriors but also intimate friends who express empathy for each other.

The motif of the armor also addresses the topic of male friendship. It works on a literal as well as a symbolic level. The armor signifies Achilles' identity and Patroclus' identification with Achilles. Since both the old and the new armor are gifts of the gods, they are vested with divine power which protects the legitimate owner but not necessarily the wearer from any harm. That is why both Patroclus and Hector can be killed even while wearing Achilles' armor. The armor also serves as a marker of male homosocial relationships, including kinship, friendship, and hostility, which change throughout the story:

1. Hephaestus gives the armor to Peleus

2. Peleus gives it to this son Achilles

3. Achilles lends it to his friend Patroclus

4. Hector steals it from his enemy Patroclus

5. Hephaestus gives new armor to Achilles

6. Achilles kills Hector (still wearing Achilles' old armor) divine protection

kinship

friendship

hostility

divine protection

revenge

With the transfer of the armor, social relationships between men are instigated. Since these relationships are charged with affective energy, they can be described as expressions of what Eve Kosofsky Sedgwick calls "male homosocial desire." ${ }^{10}$ Thus, the armor has two meanings. On the one hand, it is part of and leads to certain interactions between men. On the other hand, it signifies the continuum of male homosocial desire,

\footnotetext{
9 Homer Iliad 11.787.

10 Eve Kosofsky Sedgwick, Between Men - English Literature and Male Homosocial Desire (New York: Columbia University Press, 1985) 49-66.
} 
which, as Sedgwick argues, is often mediated by women. Achilles' mother Thetis is in the position of the mediator when asking Hephaestus to forge a new armor for her son.

The replacement of the stolen armor as well as the grief of Achilles over Patroclus is told in the eighteenth book of the Iliad. When a messenger appears to inform Achilles about the death of his friend, the latter is overwhelmed by a terrible suspicion (18.1-15):

So the men fought on like a mass of whirling fire as swift Antilocus raced the message toward Achilles. Sheltered under his curved, beaked ships he found him, foreboding, deep down, all that had come to pass. Agonizing now he probed his own great heart: "Why, why? Our long-haired Achaeans routed again, driven in terror off the plain to crowd the ships, but why?

Dear gods, don't bring to pass the grief that haunts my heart the prophecy that mother revealed to me one time... she said the best of the Myrmidons - while I lived would fall at Trojan hands and leave the light of day. And now he's dead, I know it. Menoetius' gallant son, my headstrong friend! And I told Patroclus clearly, 'Once you have beaten off the lethal fire, quick, come back to the ships - you must not battle Hector!"

The message of Patroclus' death leaves Achilles speechless. He expresses his grief by physical gestures that indicate his wish to join his friend in death (18.24-30):

A black cloud of grief came shrouding over Achilles. Both hands clawing the ground for soot and filth, he poured it over his head, fouled his handsome face and black ashes settled onto his fresh clean war-shirt. Overpowered in all his power, sprawled in the dust, Achilles lay there, fallen...

tearing his hair, defiling it with his own hands.

The messenger is aware of Achilles' suicidal thoughts and holds his hands in order to prevent him from killing himself (18.36-38):

Antilochus kneeling near, weeping uncontrollably, clutched Achilles' hands as he wept his proud heart out for fear he would slash his throat with an iron blade.

Achilles' wish to join his dead friend underlines the concept of passionate friendship. Friendship is presented here as a union of two persons in life and death. Achilles loves his friend as much as his own life. When the 
comrades join in his grief, Achilles' mother comes to help her son mourning for his friend (18.62):

I am agony - mother of grief and greatness - O my child!

This is an ironical inversion of the previously described scene (Iliad 16.112) in which Achilles had pitied his lamenting friend Patroclus. Now it is Achilles who desperately seeks motherly comfort. When Thetis encourages her son to allow himself to grieve, Achilles answers (18.92-109):

O dear mother, true! All those burning desires

Olympian Zeus has brought to pass for me -

but what joy to me now? My dear comrade's dead -

Patroclus - the man I loved beyond all other comrades,

loved as my own life - I've lost him - Hector's killed him,

stripped the gigantic armor off his back, a marvel to behold -

my burnished gear! Radiant gifts the gods presented Peleus

that day they drove you into a mortal's marriage bed...

I wish you'd lingered deep with the deathless sea-nymphs,

lived at ease, and Peleus carried home a mortal bride.

But now, as it is, sorrows, unending sorrows must surge

within your heart as well - for your own son's death.

Never again will you embrace him striding home.

My spirit rebels - I've lost the will to live,

to take my stand in the world of men - unless,

before all else, Hector's battered down by my spear

and gasps away his life, the blood-price for Patroclus,

Menoetius' gallant son he's killed and stripped!

When Achilles calls Patroclus his "my dear comrade...the man I loved beyond all other comrades, loved as my own life," he refers to five frequent features of the premodern discourse on male friendship:

(1) Male friendship is a form of love.

(2) Male friendship is an exclusive relationship with one partner.

(3) Male friendship is a union of two persons who wish to live and die together.

(4) Male friendship implies passion in the sense of strong emotions.

(5) Male friendship implies passion in the sense of suffering and death.

In his lament, Achilles also refers to the triangular relationship between his friend Patroclus, his enemy Hector, and himself as well as to the leitmotif of the armor. As soon as Achilles has finished his monologue, Thetis promises him to take care of a new armor. 
The second lament is located in the twenty-third book of the Iliad, in which Homer describes the funeral games for Patroclus. Achilles asks the Myrmidons to help him bewail the late Patroclus and to organize funeral games in his honor. Thetis shows up to rekindle their pain. In the first part of his lament, Achilles promises to take revenge (23.22-27):

Farewell, Patroclus, even there in the House of Death! Look - all that I promised once I am performing now: I've dragged Hector here for the dogs to rip him raw and here in front of your flaming pyre I'll cut the throats of a dozen sons of Troy in all their shining glory, venting my rage on them for your destruction!

In the second part of his lament, Achilles announces that he refuses to take a bath until the burial of his friend and that he will cut his hair for him (23.50-54):

No, no, by Zeus - by the highest, greatest god!

It is sacrilege for a single drop to touch my head until I place Patroclus on his pyre and heap his mound and cut my hair for him - for a second grief this harsh will never touch my heart while I am still among the living.

This way, Achilles demonstrates that he has entered a rite of passage. His words and gestures both imply his passage from life to death. When he parts from his comrades to withdraw to the shore - i.e., to the boundary between land and water - it becomes even clearer that his life is completely transforming. He falls asleep, and the ghost of his dead friend appears. Patroclus reminds Achilles of their shared life and expresses his desire to be reunited with his friend in death (23.89-110):

Oh give me your hand - I beg you with my tears! Never, never again shall I return from Hades once you have given me the soothing rites of fire. Never again will you and I, alive and breathing, huddle side-by-side, apart from loyal comrades, making plans together - never...

But one more thing. A last request - grant it, please. Never bury my bones apart from yours, Achilles, let them lie together... just as we grew up together in your house,...

Then the famous horseman Peleus took me into his halls, he reared me with kindness, appointed me your aide. 
So now let a single urn, the gold two-handled urn your noble mother gave you, hold our bones - together!

Patroclus' speech describes friendship as lifetime companionship that begins in childhood and survives death. The two-handled urn symbolizes the lasting unity of the friends. While the two handles refer to the friends, the gold of which it is made signifies the value and honor of their relationship. Again, Achilles' mother plays an important role by handing over that urn to her son and thus providing him with the symbol of his endless friendship with Patroclus. In this context, friendship and kinship intermingle. Being friends simultaneously means being as intimate as brothers. Achilles promises to fulfill Patroclus' request (23.111-119):

Why have you returned to me here, dear brother, friend?

Why tell me of all that I must do? I'll do it all.

I will obey you, your demands. Oh come closer!

Throw our arms around each other, just for a moment-

take some joy in the tears that numb the heart!

In the same breath he stretched his loving arms

but could not seize him, no, the ghost slipped underground

like a wisp of smoke... with a high thin cry.

By attempting to hug his dead friend, Achilles touchingly demonstrates his desire for the beloved friend. Although death has separated them, Achilles and Patroclus are still united by their affection for each other (23.23-24):

All night long the ghost of stricken Patroclus

hovered over me, grieving, sharing warm tears.

Achilles wakes his comrades, sharing his vision with them and they start erecting the pyre. While Patroclus is carried to the burial place, Achilles holds his head (23.156-158):

...brilliant Achilles

held the head, in tears. This was his steadfast friend

whom he escorted down to the House of Death.

By cutting off his hair and giving it to his friend as a symbolic offering, Achilles emphasizes his union with Patroclus once more (23.163-164, 172-175):

Stepping back from the pyre he cut the red-gold lock

he'd let grow long as a gift to the river god Spercheus - ...

Now, since I shall not return to my fatherland,

I'd give my friend this lock...

and let the hero Patroclus bear it on his way. 
While the pyre is burning, Achilles pours wine onto the soil. For this purpose he uses a two-handled cup that again refers to his intimate bond with Patroclus (23.249-258):

All night long they hurled the flames - massed on the pyre, blast on screaming blast - and all night long the swift Achilles, lifting a two-handled cup, dipped wine from a golden bowl and poured it down on the ground and drenched the earth, calling out to the ghost of stricken, gaunt Patroclus.

As a father weeps when he burns his son's bones, dead on his wedding day, and his death has plunged his parents in despair... so Achilles wept as he burned his dear friend's bones, dragging himself around the pyre, choked with sobs.

In Book 18, Achilles compares his friend to a girl seeking comfort from her mother; in Book 23, the narrator in turn compares Achilles to a father weeping for his son who died on his wedding day. Achilles is like a father as well as a mother to Patroclus, while the latter is like a daughter and likewise a son to Achilles. The gender identification gets more complicated when taking into account that the narrator refers to the wedding day of the dead son. It is obvious that Patroclus is compared to a groom, even though it remains vague as to who plays the role of the bride. This role is implicitly left to Achilles. It is left to the readers to understand the funeral as a wedding ceremony uniting the friends forever.

\section{b) Lover and Beloved: Aeschylus, Plato, Aeschines}

Homer portrays Achilles and Patroclus as friends who love each other exclusively. Their bond begins in childhood and does not end in death. The two-handled urn in which they both will be buried is a symbol for their marriage-like union. While Homer makes it clear that their souls are as one, he refrains from specifying the physical dimension of their love. Dover notes that: ${ }^{11}$

Homer...nowhere speaks of an erotic relationship between Achilles and Patroclus. We would reasonably attribute the poet's silence to the absence of any erotic element from the relationship as he envisaged it.

11 Dover, Greek Homosexuality, 197. 
However, many ancient playwrights, philosophers and orators after Homer drew other conclusions. Aeschylus, Plato, and Aeschines, for example, never doubted that Achilles and Patroclus were not only friends but also lovers who entertained a sexual relationship. ${ }^{12}$

\section{The Ancient Tradition: Aeschylus}

Aeschylus' Myrmidons, which dramatized the story of Achilles and Patroclus, is lost. There are several extant fragments, though, preserved for us by subsequent ancient authors. ${ }^{13}$ As Pantelis Michelakis argues in his book Achilles in Greek Tragedy (2002), these fragments testify to a homoerotic relationship between Achilles and Patroclus. ${ }^{14}$ Those fragments belonged to the scene in which Achilles mourns his dead friend. The first one reads: 15

You showed no reverence for (my) chaste respect of (your) thighs, oh ungrateful for (my) many kisses.

Achilles accuses Patroclus of betraying him even though he has always kissed his friend's mouth and showed "respect" for his thighs. Clearly, this accusation is devised to express how much Achilles misses his friend. Since Patroclus left Achilles unwillingly, there is no reason for blaming him of infidelity. As the "respect" of the friend's thighs refers to the practice of femoral intercourse, the "many kisses" may also be considered an expression of erotic intimacy. This applies notwithstanding the attribute "chaste" Achilles adds to the noun "respect." In contrast to a Christian notion of chastity, Aeschylus refers to the integrity rather than absence of physical love. As Dover states: ${ }^{16}$

The thighs seem to have been a powerful stimulus, to judge from Sophokles fr. 320 (Ganymede's thighs 'set Zeus aflame') and Aiskhylos fr. 228 (Achilles, bereaved, recalls the thighs of Patroklos).

12 Cf. Stenger, "Patroclus": "Although there is nowhere in the Iliad any explicit reference to homosexuality, despite their close friendship, ... their relationship was later interpreted in that sense."

13 Aeschylus, Agamemnon, Libation-Bearers, Eumenides, Fragments (trans. Herbert Weir Smyth; Cambridge, Mass./London: Harvard University Press, 1992), 426.

${ }_{14}$ Cf. Pantelis Michelakis, Achilles in Greek Tragedy (Cambridge: Cambridge University Press, 2002) 41-52; Dover, Greek Homosexuality, $197 \mathrm{f}$.

${ }^{15}$ Fragment 64 (135), translated by Michelakis, Achilles in Greek Tradegy, 43.

16 Dover, Greek Homosexuality, 40; Dover refers to a different counting of the fragments. 
The second fragment also alludes to the practice of femoral intercourse where Achilles mentions the "reverent company of your thighs." ${ }^{17}$ In the third fragment, Achilles again addresses his friend's thighs, this time using a litotes:18

And yet - for that I love him - they are not repulsive to my sight.

Here Achilles declares his love for Patroclus by confessing how very much he desires his friend's thighs.

In Aeschylus' fragments the attractive thighs function as a pars pro toto for the beloved friends. A similar notion is represented in a painted bowl made in Greece around the year 500 вC - the very time when Aeschylus would have been writing the Myrmidons. The painting shows Achilles dressing the wounds of his friend:

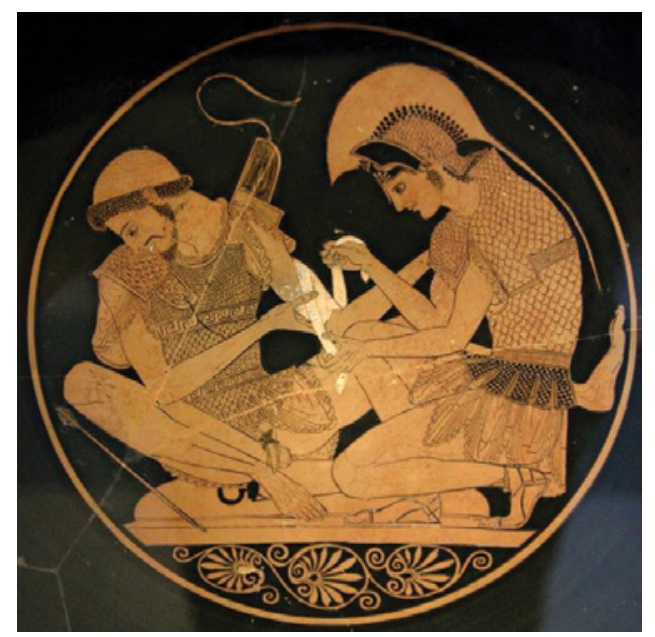

Figure 1 Achilles and Patroclus (Antikensammlung Berlin F2278). ${ }^{19}$

While Patroclus is sitting on a round shield Achilles (right) kneels next to him and wraps his left arm with a white bandage. The arrow that Achilles has removed from Patroclus' body is visible in front of them. Patroclus helps

17 Fragment 65 (136), translated by Michelakis, Achilles in Greek Tradegy, 43.

18 Fragment 66 (137), translated by Smyth, 426.

19 Tondo of an Attic red-figure kylix, ca. 500 BC, from Vulci, Wikimedia Commons, Akhilleus Patroklos Antikensammlung Berlin F2278.jpg; cf. Dover, Greek Homosexuality, 214 (R 39). 
Achilles fix the bandage but turns his face away. According to Homer, Patroclus is portrayed as the older friend. Here he wears a beard, Achilles does not. The friends are shown in a quite intimate situation. Both are naked below their transparent skirts. ${ }^{20}$ As Patroclus spreads his thighs his private parts can be seen. Dover points out:21

Patroklos in R39 (F 2278), while his wound is being bound up by Achilles, sits on his right heel in such a way that his genitals rest on the upper surface of his foot; it is as if the painter were under a powerful constraint not to conceal the genitals.

Achilles kneels exactly between the legs of his friend. Indeed, their thighs are in close company, as Aeschylus suggests. Furthermore, the geometrical composition of the painting is highly significant. The friends are surrounded by two circles - a vertical one since the bowl in which the painting is located is round, and a vertical one since the friends are sitting on a round shield lying on the ground. The center of the painting is filled by a tangle of limbs and bandages that literally ties the friends to each other. These iconographical features strongly suggest that the two warriors are also lovers. ${ }^{22}$

\section{The Ancient Tradition: Plato}

Plato mentions Achilles and Patroclus in his Symposium (179e-18ob). ${ }^{23}$ Phaedrus, one of the participants in the dialogue on love, generally agrees with Aeschylus that Achilles and Patroclus were lovers. He invokes Achilles decision to join his friend in death:

20 Dover, Greek Homosexuality, 130, states: "The clothing... may be diaphanous, especially if it is the skirt of a tunic, as in R39 (Achilles)."

21 Dover, Greek Homosexuality, 130.

22 Cf. Plato's notion of the army of lovers: “The best conceivable organization (supposing it were somehow possible) for a community or a battalion would be for it to consist of lovers and their boyfriends, since they'd compete with one another in avoiding any kind of shameful act. It's hardly an exaggeration to say that a handful of such men, fighting side by side, could conquer the whole world. I mean, it goes without saying that the last person a lover wants to be seen by, in the act of deserting or throwing away his weapons, is his boyfriend; however many times he had to choose, he'd rather die than that. And as for abandoning his boyfriend or not helping him when danger threatens - well, possession by Love would infuse even utter cowards with courage and make them indistinguishable from those to whom bravery comes most easily," Plato, Symposium (trans. Robin Waterfield: Oxford and New York: Oxford University Press, 1994) 11 (178e-179a).

23 Cf. Dover, Greek Homosexuality, 197; Michelakis, Achilles in Greek Tragedy, 47-49. 
Although Achilles found out from his mother that his killing of Hector would cause his own death and that if he avoided doing this he'd go home and die of old age, he was brave enough to stand by his lover Patroclus and to avenge him - he didn't choose just to die for Patroclus, but even to die $a s$ well as him, since Patroclus was already dead (179e).

Despite supporting Aeschylus' idea of the heroes being lovers, Phaedrus criticizes him for suggesting that Achilles was older than Patroclus. According to Homer, he claims that Achilles was younger and more attractive than his friend:

Now, Aeschylus is talking nonsense when he claims that Achilles was Patroclus' lover: Achilles was more attractive than Patroclus - in fact he was the most attractive hero there was - and was still beardless. He was also much younger than Patroclus, as Homer records. Anyway, while it's true that there is no courage which the gods value more highly than the courage of love, they are more amazed and impressed by, and more generous towards, a loved one's affection for a lover than a lover's for his boyfriend, since a lover is possessed by a god and therefore in a more godlike state than his beloved (180a-b).

In Plato's opinion, the beloved is more respectable than the lover because he is looking for knowledge and wisdom rather than beauty and youth. By stressing that Achilles is younger than Patroclus he also emphasizes the notion that Achilles was the boyfriend of Patroclus.

\section{The Ancient Tradition: Aeschines}

The Greek statesman Aeschines - one of the canonical ten Attic orators brings up the example of Achilles and Patroclus in his speech against Timarchus who had accused him on the charge of high treason. ${ }^{24}$ In his response Aeschines successfully questions Timarchus' credibility by claiming that the latter had prostituted himself to men in his youth and thus lost his civil liberty including the right to speak to the public. Aeschines insists on the distinction between prostitution and love. He claims that male-to-male prostitution is condemnable while mutual love between men is socially acceptable. By drawing on Homer's description of Achilles and Patroclus he attempts to vindicate his case against Timarchus (In Tim. 142):25

${ }^{24}$ Cf. Dover, Greek Homosexuality, 19-109, esp. 4of.; Michelakis, Achilles in Greek Trag$e d y, 5^{0}-5^{2}$.

${ }_{25}$ Aeschines, Against Timarchus, quoted after Michelakis, Achilles in Greek Tragedy, 51. 
I will speak first of Homer, whom we rank among the oldest and wisest of the poets. Although he speaks in many places of Patroclus and Achilles, he hides their love and avoids giving a name to their friendship, thinking that the exceeding greatness of their affection is manifest in those of his hearers who are educated.

As Michelakis explains: ${ }^{26}$

Aeschines argues that Achilles and Patroclus were lovers, yet he adduces as evidence of his view Homer, not Aeschylus. For Aeschines, Homer's silence over the nature of the relationship of Achilles and Patroclus makes it clear that in the Iliad the two heroes are lovers.

\section{The Modern Reception: Wolfgang Petersen's Troy (2004)}

The phenomenon of eloquent silence is as characteristic for Troy as for the Iliad. When playwright David Benioff and director Wolfgang Petersen decided to adopt Homer's Iliad as a blockbuster movie they had to consider the issue of homosexuality. It is very unlikely that they were not aware of the ancient discourse that viewed Achilles and Patroclus as lovers. Apparently the filmmakers wanted to prevent the predominantly heterosexual audience from gathering the impression that the film - featuring Brad Pitt in the role of Achilles and the formerly unknown fashion model Garret Hedlund in the role of Patroclus - was telling the story of two gay warriors.

\section{From Friendship to Kinship: Hetero-Sexualizing Achilles}

Troy responds to this dilemma by exchanging friendship with kinship. In the movie, Achilles and Patroclus are no longer friends but relatives. While in the Iliad the two characters are friends from childhood who grew up together, Troy advances their close relationship to a new level and declares them cousins. ${ }^{27}$ In the scene that shows the two warriors together for the first time, Achilles is teaching Patroclus how to master the sword. As they are fighting, Odysseus enters. This scene serves as the opportunity to introduce Patroclus: ${ }^{28}$

26 Michelakis, Achilles in Greek Tragedy, 51.

27 Cf. Kim Shahabudin, "From Greek Myth to Hollywood Story: Explanatory Narrative in Troy," in Winkler, From Homer's Iliad to Hollywood Epic, 107-118.

28 This and the following quotes were taken from www.script-o-rama.com, which no longer makes the Troy script available online. 


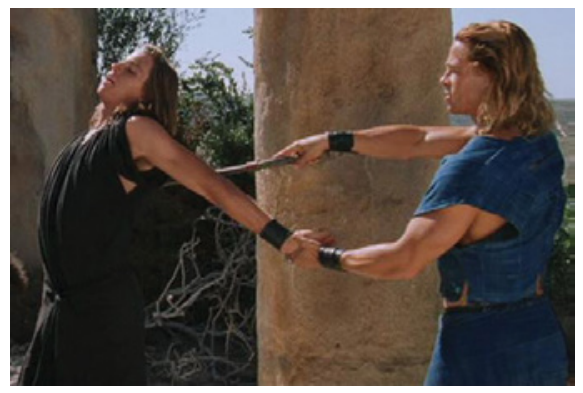

Figure 2 Achilles and Patroclus fighting.

Achilles: Patroclus, my cousin. Odysseus, king of Ithaca. Odysseus: Patroclus. I knew your parents well.

Patroclus: I miss them.

Odysseus: Now you have this one watching over you, eh?

Patroclus: Learning from Achilles himself.

Odysseus: Kings would kill for the honor.

This conversation works on two levels. The explicit message is directed at Odysseus, who learns that Achilles and Patroclus are relatives. This information is unusual because in premodern epics heroes are introduced as their father's son rather than their cousin's cousin. In fact, Odysseus replies that he knew Patroclus' parents well. The irritation resulting from this unlikely conversation is caused by the implicit message addressed to the audience rather than to Odysseus. By stating that Patroclus is his cousin, Achilles does not have to say that Patroclus is not his lover. It is the underlying performative function of this scene to confirm the taboo of homosexuality.

The dialogues and the visual representation of the story, however, seem contradictory in this scene. When Achilles is shown as a warrior teaching his youthful cousin (nephew, rather) how to handle the sword, the audience is reminded of the ancient concept of pederasty. With their long, blond hair, loose blue garments and exposed muscular arms and thighs, Achilles and Patroclus meet the homoerotic cliché of Greek athletes. Moreover, they are lookalikes - Patroclus represents a younger version of Achilles; respectively, Garret Hedlund a younger version of Brad Pitt who is twenty years older than his fellow-actor. Achilles' explicit introduction of Patroclus as his cousin leaves enough room for a strong homoerotic message that is implied by the pictures in the scene. If the viewers replaced the word "cousin" with the word "lover" - or turned off the sound - they might think this scene belonged to a gay film. 
Troy, therefore, creates a double bind: what you see is different from what you hear, and what you hear is different from what you see. When Odysseus jokingly says to Patroclus, "Now you have this one watching over you, eh?" his words insinuate a relationship between lovers. Odysseus' statement that kings would kill for the honor of being "watched over" by Achilles implies that he, being a king himself, wants to be in the position of Patroclus. Later on, when Achilles is shown in deep despair about the death of Patroclus, one of his comrades will reiterate - and thus remind the audience - that they were cousins - not lovers.

While Homer tells the story of a male homosocial world, the film heterosexualizes the constellation of characters. Troy establishes a network of parallel homosocial as well as heterosexual couples amongst the Greeks as well as the Trojans. The relationship between Achilles and Patroclus is mirrored by the relationship between Hector and Paris. They are also presented as relatives who look alike despite of their age difference. Paris is a younger version of Hector, as Patroclus is a younger alter ego of Achilles. In both cases the rivalry of two men over a woman is crucial. As Paris kidnaps Helen, who is the wife of the Spartan King Menelaus, Achilles kidnaps Briseis, who - in the film, not in Homer's epic - is introduced as the niece of the Trojan King Priam. In the Iliad, the story of Briseis is only briefly mentioned when she is kidnapped and returned. Petersen's Troy, however, transforms this minor episode into a full-fledged love story including a dramatic scene that shows Achilles rescuing Briseis from the burning city of Troy. Correspondingly, Paris makes sure that Helen and Andromache get saved from the fire. In the film Hector and Andromache have a baby that is also rescued. Thus, the film provides the male heroes with heterosexual love stories that are not even part of Homer's text. Again, the strategy of hetero-sexualizing the male heroes results in ambivalence. By stressing the parallel of the two male couples (Achilles/Patroclus, Hector/Paris), the film not only elaborates the patriarchal ideal of male solidarity and fighting spirit but also abets the suspicion of homosexuality. Adding women, heterosexual desire, and babies to the male heroes averts this suspicion.

\section{Queer Moments: Of Armors and Necklaces}

The film is quite vague about the quality of affective bonds between men. On the one hand it enhances the intimacy of the relationship between Achilles and Patroclus, on the other it sends strong signals that discour- 
age possible suspicions of homosexuality. I would like to argue that this ambiguity is a deliberate strategy of the film in order not to frighten the heterosexual audience away. ${ }^{29}$ As Sedgwick argues, patriarchal societies are based on male bonds charged with homosocial desire. ${ }^{30}$ She suggests that the virtual continuum of male homosocial desire is disrupted by the taboo of homosexuality. Paradoxically, the rigorous denial of homosexual desire allows a maximum increase of homosocial desire. As long as men deny being homosexual, they are permitted to maintain affective or even passionate relationships with other men. However, the heteronormative framework of Troy is undermind by several queer moments. As shown earlier, Homer uses the motif of the transferred armor to mark a series of male homosocial bonds. The armor is given first from Peleus to his son Achilles, then from Achilles to his friend Patroclus, and eventually from Patroclus to their enemy Hector. In Troy only one transfer of the armor is accounted for, namely, the transfer from Achilles to Patroclus. While the reader of Homer's Iliad is aware that it is Patroclus who is wearing Achilles' armor, the audience of Troy is as much surprised as Hector when it turns out that he killed Patroclus instead of Achilles.

While the film reduces the number of armor transfers, it introduces the symbol of the seashell necklace as compensation. We need to take a closer look to understand what happens to the necklace. To begin with, Achilles' mother Thetis collects shells from the ocean and tells her son:

I'm making you another seashell necklace. Like the ones I made you when you were a boy. Do you remember?

Later in the film Achilles removes the necklace from his dead friend's neck and eventually gives it to his lover Briseis. This implies that Achilles once gave the necklace as a sign of his love to Patroclus, an event not shown in the film. By being transferred,

1. from Thetis to Achilles,

2. from Achilles to Patroclus,

3. from Patroclus to Briseis,

${ }^{29}$ For contrast, see Konstantinos P. Nikoloutsos, "The Alexander Bromance: Male Desire and Gender Fluidity in Oliver Stone's Historical Epic," Helios 35 (2008) 223-251.

30 See note 8 . 
the necklace indicates a genealogy of desire including three kinds of love that appear equivalent (see Figures 3-5).

Achilles loves Patroclus like a mother loves her son and like a man loves his concubine. The shell necklace as motif of a transferred object allows much more interpretational leverage than the armor, which is a signifier of male homosocial desire. While the armor represents masculinity, the necklace made of seashells symbolizes femininity. The shell can even be interpreted as a vaginal symbol as opposed to the phallic sword by which both Patroclus and Hector are killed. By putting Achilles' relationship to Patroclus on the same level with his relationship to Briseis - a symbolic transaction performed in the name of the mother - the film blurs the dividing line between homo- and heterosocial (if not homo- and heterosexual) desire. Still, the border is reinstated at the same time. When Thetis gives the necklace to her son, she reminds him of the fate the gods have imposed on him. Either he will marry a woman, live happily, and eventually be forgotten, or he will join the war, be killed in battle, and hence be commemorated forever. A decision needs to be made for either Patroclus or Briseis. Obviously Achilles prefers and thus chooses Patroclus. When Achilles eventually gives the necklace to Briseis, she will clearly not be the replacement for Patroclus because Achilles himself is going to die very soon. Nevertheless, the handing over of the token of love is quite suitable to please that part of the audience that prefers the heteronormative rather that the queer reading of the film.

\section{Conclusion}

While Homer's Iliad presents the lifetime relationship between Achilles and Patroclus as a passionate friendship, Petersen's Troy exchanges friendship for kinship to obscure the well-known fact that in the ancient tradition the relationship of the two brothers-in-arms was explicitly interpreted as mutual love, which included sexual intercourse. While Homer restricted himself to a symbolic mise-en-scène (exchange of armors, twohandled urn, feminization of the friends, mother as mediator), Aeschylus, Plato, and Aeschines openly discuss the erotic dimension of their love. Plato takes issue with Aeschylus over whether Achilles was the lover or the beloved, and Aeschines reads Homer's silence about the sexual quality of the relationship as a sign of decency rather than denial. Obviously, they considered love between men a socially acceptable if not desirable kind of male homosocial desire. This changed when the ancient discourse 


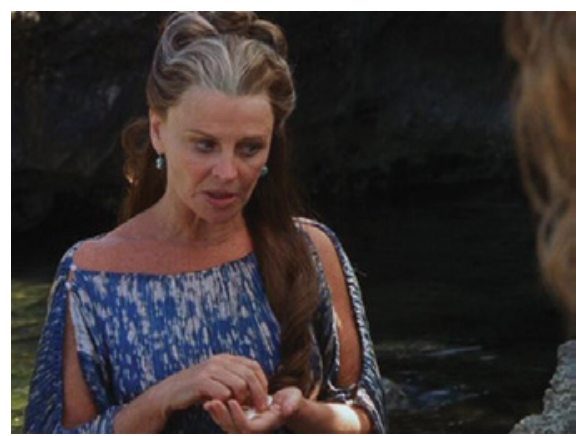

Figure 3 Thetis collects shells.

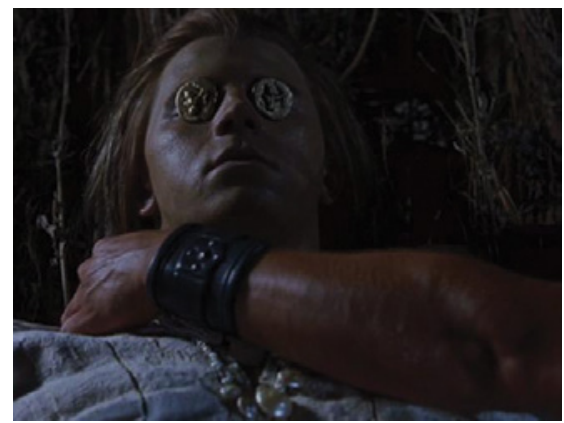

Figure 4 Achilles removes the seashell necklace from Patroclus' neck.

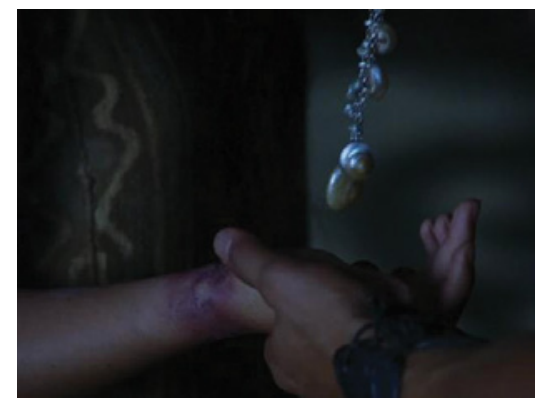

Figure 5 Achilles hands the seashell necklace over to Briseis. 
of pederasty - not to be confused with pedophilia - was replaced by the medieval discourse on sodomy and subsequently by the modern discourse of homosexuality. As opposed to the Iliad, Troy had to deal with the taboo of male homosexuality. It does so by creating a double entendre that works for both the heterosexual and homosexual audience. The heterosexual audience is invited to read the story of Achilles and Patroclus as one about close relatives who take care of each other and to identify with the patriarchal ideal of male homosociality. Homosexual viewers, however, are free to focus on the pictures that allow a queer interpretation of the story. Troy exploits the fact that the relationship between Achilles and Patroclus can be understood either as homosociality or as homosexuality, depending on whether the audience focuses on the explicit or the implicit message of the film.

\section{Works Cited}

Aeschylus. Agamemnon, Libation-Bearers, Eumenides, Fragments (trans. Herbert Weir Smyth; Cambridge, Mass./London: Harvard University Press, 1992).

Boswell, John. "Battle-Worn: Gays in the Military 300 B.C.," in The New Republic 208 (May 1993) $15^{-18 .}$

- Christianity, Social Tolerance, and Homosexuality: Gay People in Western Europe from the Beginning of the Christian Era to the Fourteenth Century (Chicago/London: University of Chicago Press, 1980).

Burg, B.R., ed. Gay Warriors, A Documentary History from the Ancient World to the Present (New York: New York University Press, 2002).

Dover, Kenneth J. Greek Homosexuality (rev. ed.; Harvard University Press, Cambridge, Massachusetts, 1989).

Hartmann, Elke. "Homosexuality," in The New Pauly, Brill Online, accessed November 25, 2011.

Homer. The Iliad (trans. Robert Fagles; New York: Penguin Classics, 1990).

Krass, Andreas. "Achill und Patroclus. Freundschaft und Tod in den Trojaromanen Benoîts de Sainte-Maure, Herborts von Fritzlar und Konrads von Würzburg," in Zeitschrift für Literaturwissenschaft und Linguistik 114 (1999) 66-98.

—_. "Männerfreundschaft. Bündnis und Begehren in Michel de Montaignes Essay De l'amitié," in Andreas Krass and Alexandra Tischel, eds., Bündnis und Begehren. Ein Symposium über die Liebe, (Berlin: Geschlechterdifferenz und Literatur, 2002) 127-141.

Michelakis, Pantelis. Achilles in Greek Tragedy (Cambridge: Cambridge University Press, 2002).

Myrsiades, Kostas, ed. Reading Homer: Film and Text (Madison, NJ: Fairleigh Dickinson University Press, 2009).

Nikoloutsos, Konstantinos P. "The Alexander Bromance: Male Desire and Gender Fluidity in Oliver Stone's Historical Epic," Helios 35 (2008).

Plato. Symposium (trans. Robin Waterfield: Oxford and New York: Oxford University Press, 1994).

Sedgwick, Eve Kosofsky. Between Men - English Literature and Male Homosocial Desire (New York: Columbia University Press, 1985). 
Shahabudin, Kim. "From Greek Myth to Hollywood Story: Explanatory Narrative in Troy," in Winkler, From Homer's Iliad to Hollywood Epic, 107-118.

Sigel, Dorothea. "Achilles," in The New Pauly, Brill Online, June 29, 2010, accessed November 25, 2011.

Stenger, Jan. "Patroclus," in The New Pauly, Brill Online, accessed November 25, 2011.

Winkler, Martin M., ed. Troy: From Homer's Iliad to Hollywood Epic (Malden, MA: Blackwell, 2007). 



\title{
MODELS OF MASCULINITIES IN TROY: ACHILLES, HECTOR AND THEIR FEMALE PARTNERS
}

\author{
Celina Proch and Michael Kleu
}

\section{Introduction - What Does it Mean to Be a Man?}

Films, as reconstructions and interpretations of reality, provide insights into social constructions of reality. ${ }^{1}$ They are one of the visual forms in which and with which a contemporary society is portrayed. ${ }^{2}$ Popular and successful Hollywood cinema productions have therefore proven to be an abundant resource for analyzing gender relations. Films set in the ancient world are no exception. In fact, while they usually employ storylines passed down over many centuries, they often turn out to be especially interesting in the ancient and modern values, moral conceptions, and societal norms they adopt and implement.

Our particular focus here is Wolfgang Petersen's Troy, ${ }^{3}$ which is "inspired by" Homer's Iliad and focuses on two male characters - the Greek Achilles, introduced via a text insertion at the beginning of the film as the mightiest warrior of all times, and his Trojan counterpart Hector, the heir to King Priam's throne. ${ }^{4}$ The intention of this study is to analyze the depiction of masculinity in the film by examining both the representation of Achilles and Hector and the extent to which the narrative structures and

1 See Rainer Winter, "Film und gesellschaftliche Wirklichkeit. Zur Aktualität der Filmsoziologie", in Jutta Allmendinger et al., eds., Entstaatlichung und soziale Sicherheit. Verhandlungen des 31. Kongresses der Deutschen Gesellschaft für Soziologie (Opladen: Leske und Budrich, 2004) 112.

2 Norman K. Denzin, "Reading Film - Filme und Videos als sozialwissenschaftliches Erfahrungsmaterial”, in Uwe Flick, Ernst von Kardorff und Ines Steinke, eds., Qualitative Forschung. Ein Handbuch. (Reinbek bei Hamburg: Rohwolt, 200o) 416-428.

3 For reference, we are using the 2007 director's cut. For Troy in film, see Anja Wieber, "Vor Troja nichts Neues? Moderne Kinogeschichten zu Homers Ilias," in Martin Lindner, Drehbuch Geschichte: Die antike Welt im Film (Münster: LIT, 2005) 137-162; Martin M. Winkler, ed., Troy: from Homer's Iliad to Hollywood Epic (Malden, MA: Blackwell, 2007); Wolfgang Kofler and Florian Schaffenrath, "Petersens epische Technik: Troja und seine Homerische Vorlage," in Stefan Neuhaus, ed., Literatur im Film: Beispiele einer Medienbeziehung (Würzburg: Königshausen \& Neumann, 2008) 313-330.

4 Most film adaptions focus on Helen and the conquest of Troy, so Achilles is usually disregarded or plays a minor role. Cf. Susanne Gödde, "Achilleus," in Der Neue Pauly, suppl. 5 (2008) 13. The same applies to Hector. 
the staged manliness contain references to values and standards in the real world.

In our title we have deliberately chosen to employ the term "masculinities" in its plural form following the assumption of a diversity of masculinities that form the basis of Raewyn Connell's influential sociological research widely promulgated in her 1995 book of that title. ${ }^{5}$ Connell's conclusions provide the groundwork for our typology of the forms of masculinity. But before we commence with the analysis of manhood in Troy's Achilles and Hector, we have to delineate several aspects of gender. We define gender as a social and cultural construction. Different designs of gender can be found in diverse cultures and historical epochs. The disparity between them is determined by not only the cultural and historical environment but also the local social context in which an individual dwells. Within a school, neighborhood, or work place, one can identify different constructs of masculinity as well as various patterns of behavior and ways of dealing with the male body.

This spectrum of masculinities is shown to the audience of Troy in the form of personified characters. The filmmakers present a variety of masculinity types which portray the genre's binary oppositions - good and evil. ${ }^{6}$ According to Connell's model of social gender structure, masculinity is always conceived in relation to various masculinities as well as in relation to women, whereby the relations are characterized by a difference in access to power. This hierarchy is topped by the so-called hegemonic masculinity. At the bottom of the hierarchy is where one finds women; in between the two are the other forms of masculinity. The latter are characterized by subordination, complicity, or marginalization. Hegemonic masculinities are the most important pillars of patriarchy, perpetuating the existing social system by persistently reproducing the relations of power. Marginalized masculinities have access to fewer resources of power than the hegemonic. Characteristically included in this lower cat-

5 Originally published in 1995 by Allen \& Unwin, now in a second edition: Raewyn Connell, Masculinities (Berkeley and Los Angeles, University of California Press, 2005). We have employed the German translation by Christian Stahl: Robert W. Connell, Der gemachte Mann. Konstruktion und Krise von Männlichkeiten (Opladen: Leske und Budrich, 1999).

6 Following predominantly Martin Lindner, Rom und seine Kaiser im Historienfilm (Frankfurt am Main: Verlag Antike, 2007) 98-103, 180f., and 214, we employ the term "filmmakers," because in addition to the director Wolfgang Petersen, the producers, scriptwriters, artistic designers, and not at least the actors have an influence on the final presentation of the movie as well. 
egory are homosexuals and heterosexuals with female attributes. ${ }^{7}$ But masculinities can also be marginalized if their status is lowered because of their ethnicity, class membership, or social status. Complicity as a form of manhood covers those masculinities that do not match the hegemonic ones but nonetheless benefit from their status and thereby participate in the patriarchal dividend. These variations of classification make clear that Connell's model is a dynamic one in which it is not always possible to separate the attributes clearly. And, lastly, the relations of power can be changed at any time, and the occurrence of an attribute can express itself differently from individual to individual.

In Troy the diversity of masculinities is illustrated by means of different social and hierarchic positions - kings and armies, leaders and subordinates. Even within the army there are warriors with a particular prestige. In the Thessalian army, for example, Boagrius immediately captures the audience's attention by his impressive body height and muscle mass. According to Connell, there was and still is no field more important for the construction of masculinities in the Western world than the military. ${ }^{8}$ Watching a film about the Trojan War, the audience finds itself taken into an ancienttype world of particularly masculine dominance, and here Achilles and Hector quite obviously represent hegemonic masculinities. Both are military leaders, highly appreciated by their soldiers, each of them playing the role of the mightiest warrior in their respective armies. ${ }^{9}$

To a lesser extent Achilles and Hector also fulfill the criteria for complicity. Hector supports his father Priam in order to keep alive the latter's hegemony from which he benefits directly as the heir to the throne and successor to the position of paterfamilias. Achilles condemns Agamemnon, but he needs to fight in the king's war in order to win the immortal glory he longs for so badly. Although reluctant to serve under Agamemnon, early on in the film we see that he is willing to accept this relationdependence. ${ }^{10}$

7 In Troy one can identify Paris as a representative of this type of masculinity because of his traditionally female characteristics. For example, his actions are motivated by emotions and he acts cowardly in battle.

8 Robert W. Connell, "Arms and the Men: Using the New Research on Masculinity to Understand Violence and Promote Peace in the Contemporary World," in Ingeborg Breines, Raewyn Connell, and Ingrid Eide, eds., Male Roles, Masculinities and Violence: A Culture of Peace Perspective (Paris: UNESCO, 2000) 21-31.

9 Connell describes military leaders as prime examples for hegemonic masculinity. Cf. Connell, Der gemachte Mann, 98.

10 At the same time Agamemnon is dependent on Achilles without whom he cannot win the war. But ultimately Agamemnon and not Achilles is the commander-in-chief of the Greeks. 
Insofar as subordination is concerned, there is a significant difference between Achilles and Hector. Hector obeys his father's commands because he benefits from the latter's reign, and he also represents the ideal son who honors his father's word, even if he might entirely disagree with him. ${ }^{11}$ Achilles does not obey Agamemnon, and he makes it clear that he does not consider Agamemnon to be his king. He listens only to people he trusts - like Odysseus. Their circumstances differ somewhat: Hector subordinates himself to some kind of ideal king, while Achilles refuses to obey a demonstrably poor ruler..$^{12}$ In this regard, subordination is not a useful criterion for analyzing the different representations of manliness illustrated by Achilles and Hector.

Achilles and Hector therefore both represent a hegemonic masculinity combined with some elements of complicity. On the other hand, although Achilles and Hector both conform to Connell's typology in these ways, their characters differ considerably from one another's. We will discuss this aspect of their characterization insofar as it pertains to their relations with their female partners, but only after we have focused our analysis on several physical aspects of the performances by the actors portraying our heroes.

\section{Stars, Gendered Bodies and the Female Gaze - the Corporeality of the Heroes}

Gender is understood not as a characteristic but as a social experience of interacting individuals. According to Judith Butler, this is particularly relevant to the performative construction of gender. ${ }^{13}$ The body fulfills social actions and serves thereby as a production site of gender-defining behaviors. Since we are engaged in examining the construction of masculinities in Troy, first we have to elaborate on the physical construction of manhood. Gender is defined in most film productions by resorting to standardized visual images. The gender identity is recognizable as a procedural and emblematic system. Achilles' and Hector's body representa-

11 The ideal son motif corresponds with Hector's image in the Iliad. Cf. Georg Wöhrle, Telemachs Reise. Väter und Söhne in Ilias und Odyssee oder ein Beitrag zur Erforschung der Männlichkeitsideologie in der homerischen Welt (Göttingen: Vandenhoeck \& Ruprecht, 1999) $85^{-98}$.

12 It is not by chance that King Priam brings Achilles to his senses and that the latter tells him: "You are a much better king than the one leading this army."

13 Judith Butler, "Leibliche Einschreibungen, performative Subversionen," in Das Unbehagen der Geschlechter (trans. Kathrina Menke; Frankfurt am Main: Suhrkamp, 1991) 190-208. 
tion is based mainly on the choice of the actors. Since teenagers are one of the main target groups for a blockbuster film, the casting process tends to focus on the idols of younger demographic groups. ${ }^{14}$ By casting Brad Pitt, the filmmakers chose definitively one of the most successful male darlings of the public, an established sex symbol. Because every image involves special audience expectations concerning physical appearance, the actor who would portray Achilles embarked upon a course of intensive muscle training so he could embody the viewers' ideal of what the mightiest Greek fighter in the Trojan War would look like. ${ }^{15}$ Pitt's enormous success as an actor proves that the concept of masculinity he represents has an important significance to the social discourse in our contemporary world. By casting Eric Bana for the role of Hector, the filmmakers chose a less popular actor. Nevertheless, his body constitution meets the demands of the target group regarding a hero.

The film displays the bodies of Achilles and Hector as trained and tailored for fighting, especially when compared to those of Agamemnon and his brother Menelaus. Agamemnon, who appears on the battlefield only rarely, appears to have a strong body, as does his brother, but they are clearly more barrel-chested and corpulent than well-defined and muscular. And they clearly have more body hair than the younger warriors. In contrast to these negative characters, Achilles und Hector represent the current ideal of male beauty.

Drawing upon classical feminist film theory, Laura Mulvey writes about the male gaze, which determines "three different looks" associated with cinema: those of the camera, the audience, and the actors as they look upon each other. ${ }^{16}$ In Troy we can speak also of a female equivalent: the female-heterosexual audience looks at a stage-managed spectacle created especially for her. However, the heterosexual-male audience is not neglected either. The audience's inner Narcissus is satisfied by identifying with the cinematic male heroes. The male protagonist Achilles, who is

14 Wieber, "Vor Troja nichts Neues?" 157 and 161.

15 Susanne Weingarten, Bodies of Evidence. Geschlechtsrepräsentationen von Hollywoodstars (Marburg: Schüren, 2003). In films set in the ancient world, the male protagonists are by tradition muscular. Cf. Anja Wieber-Scariot, "Film," in Der Neue Pauly 13 (1999), Supp. 1133-1141, esp. 1137. Kim Shahabudin, "From Greek Myth to Hollywood Story, Explanatory Narrative in Troy," in Winkler, Troy, 109-110: "While stories in the press continued to refer to Homer's poem and Schliemann's excavations, the main focus of publicity prior to release was on the film's exposure of Brad Pitt's body."

16 Laura Mulvey, "Visuelle Lust und narratives Kino," 30-46 in Gertrud Nabakovski, Helke Sander, and Peter Gorsen: Frauen in der Kunst (Band I, Frankfurt am Main: Suhrkamp, 1980). 
genre-typical, becomes the object of viewing pleasure. In several close-ups the male and female watchers can enjoy Brad Pitt's muscular, well-defined body. But in several notable themes Achilles is presented in a manner usually employed in the traditional fragmentary portrayal of women. In a love scene with Briseis that we discuss below, the audience's attention is directed to Achilles' body, shown in a feminized way as a male pinup. Traditionally the beautiful body is the female's sphere. In Troy female characters are usually clothed - except for Helen and two nameless playmates of Achilles. ${ }^{17}$ In contrast, it is Achilles' male body that is used in ways usually reserved for big-screen females. In many scenes the audience sees Achilles in his tent, which would normally provide the traditional domestic sphere of the female. We can watch him changing his clothes and washing himself, and at one point he is totally naked. When he does not wear his armor, the clothing he wears over his shoulders sports a low neckline that clearly corresponds to traditional cinematic female style, contrasted by his modern looking boots - Achilles is never shown in sandals - and unshaved armpit hair. ${ }^{18}$

In its subtext Troy gives plenty of possibilities for a homosexual, oppositional ("counter-hegemonic") reading. ${ }^{19}$ But because homoeroticism and explicit exhibition of the male body as an erotic object are still proscribed in our contemporary society, the filmmakers fully distract the audience from the erotically motivated view - which the audience does not even admit to itself. ${ }^{20}$ Abiding by a veritable production code, by which we mean the self-censorship by filmmakers fearful of pressure from socially conservative special interest groups, the audience is repeatedly reminded of Achilles' heterosexuality, which they are accustomed to reading as the norm in a blockbuster film. For example, although the film depicts Achilles and Patroclus as handsome and athletic young men, the audience is immediately and clearly told that they are cousins. In this way

17 Here the filmmakers defy genre conventions. Usually the staging of women is connected with eroticization. Anja Wieber-Scariot: "Film," 1137.

18 Cf. Wieber: "Vor Troja nichts Neues?" 159.

19 See Stuart Hall, "Encoding/decoding," in Centre for Contemporary Cultural Studies, ed., Culture, Media, Language: Working Papers in Cultural Studies, 1972-79 (London: Hutchinson, 1980) 128-38. In his work Hall describes different kinds of decoding media messages: the dominant, the negotiated, and the oppositional reading. The latter describes readers, whose social situation places them in a directly oppositional relation to the dominant code. He or she understands the preferred reading but does not share the told code and therefore rejects the dominant reading.

20 In Anja Wieber's point of view, homoerotic motivated curiosity is nowadays not a taboo anymore for the film industry. Cf. Wieber, "Antike am laufenden Meter: Mehr als ein Jahrhundert Filmgeschichte," in Mischa Meier and Simona Slanicka, eds., Antike und Mittelalter im Film: Konstruktion - Dokumentation - Projektion (Köln: Böhlau Verlag, 2007) 34. 
the filmmakers employ a strategy for stating heteronormativity and avoid any suspicion of establishing a homoerotic relationship between them. ${ }^{21}$ Similarly, when the audience views Achilles' bare back, the filmmakers make sure that Briseis is included in the shot. This is a strategically functional move designed to engage the male spectator. By arranging a mixedgender ensemble to legitimate his visual reception of male nudity they free him from suspecting that Achilles is homosexual. Another strategy of legitimization that avails the audience of a free view of the masculine body is the athletic staging. Although the audience sees Achilles' body in a number of battle scenes, here the male body is not only beautiful but functional: the muscles are used as battle weapons, as tools for winning a contest, and not as attributes of attractiveness. ${ }^{22}$

The visual representation and display of Achilles in Troy is remarkable in alternating throughout the film between a male and a female delineation. Within the domestic sphere of his tent he performs in a feminized and erotic way, while in battle his body resembles an extremely violent war machine. The filmmakers illustrate the Homeric epithet "swift-footed" by conferring upon him a fighting style characterized by speed and athletic grace and balance. ${ }^{23}$ We see this fighting style for the first time in his initial action sequence - the combat with Boagrius. Although the hero has overslept after an apparently exhausting night with the two aforementioned naked women, he quickly dispatches this visually intimidating warrior. With quick steps Achilles runs towards him, jumps up high in the air, and kills him with a single stab of his sword. This graceful act of killing is presented in one of the few slow-motion scenes of the movie, presumably to warrant special attention from the audience. Later, at the action climax of the film, the performance of Achilles' body stands out during the staging of his death. Unlike the other victims of the war, Achilles remains apparently unharmed until the very end, and his death scene continues to emphasize the aesthetical depiction of his attractive, albeit expiring, body.

21 Cf. Kofler and Schaffenrath: "Petersens epische Technik," 319, footnote 16; Shahabudin, From Greek Myth to Hollywood Story, 113; Wieber, "Vor Troja nichts Neues?" 160-161. While the nature of their relationship remains open in the Iliad, some of the later ancient traditions regard them as a couple. See Krass in this volume.

22 Steve Neale, "Masculinity as Spectacle: Reflections on Men and Mainstream Cinema," in Steven Coham and Ina Rae Hark, eds., Screening the Male: Exploring Masculinities in Hollywood Cinema (London: Routledge, 1994) 9-20; also Guido Zurstiege, "Fit und flott - und ein wenig sexy in schwarz-weiß, die strukturelle Ambivalenz werblicher Medienangebote," in Christina Holtz-Bacha, ed., Stereotype? Frauen und Männer in der Werbung (Wiesbaden: VS Verlag für Sozialwissenschaften, 2008) 107-123.

23 Cf. Kofler and Schaffenrath, "Petersens epische Technik," 320-324. 


\section{The Hero and His Relationships: Achilles the Lonely Hero}

The first time we see Achilles on the screen he is naked and asleep between two undressed women. This tableau is significant for his characterization, for it characterizes him as a heterosexual, white man - two of Connell's attributes of hegemonic masculinity. The audience assumes that for Achilles women must be merely objects of sexual desires. This is underlined by his sleeping with two women instead of only one, a sign of his virility. If Achilles had been introduced lying in bed with only one woman, the audience might have interpreted this to mean that he had a stable relationship. But by being shown together with two women, the assumption instead is that Achilles is the personification of a single man who refuses to integrate into society. His marital status represents his resistance to social norms, his refusal to assume adult responsibilities and commit to a family, the latter sphere usually the realm of women. The only two things Achilles seems to be interested in are immortal fame and his cousin Patroclus. ${ }^{24} \mathrm{He}$ follows his own set of values, and this results frequently in irresponsible behavior. For example, because he oversleeps he arrives late for the battle against the Thessalians. Notable as well is that Achilles is the only Greek wearing turquoise clothes, the lone exception being his mother Thetis, who is actually a goddess. This color is in other scenes almost exclusively reserved for the Trojans, and it clearly portrays a positive ambience. ${ }^{25}$

After the warlike Achilles leads the Greek army in successfully establishing a beachhead along the Trojan coastline, his priorities start to change. His soldiers, the Myrmidons, find Briseis hiding in Apollo's plundered temple and bring her to Achilles' tent. Briseis is the niece of the Trojan king Priam and the cousin of his sons Hector and Paris, and she was introduced in the film when her cousins returned from their diplomatic mission to Sparta. This is a scene of pageantry, and she is introduced prominently when first Paris, then Hector, and finally King Priam address and call her by name, thereby signalizing the significance of her character. The brothers are pleasantly surprised to see and hear that Briseis has become a ser-

24 Shahabudin, "From Greek Myth to Hollywood Story," 116: "The main theme of Troy, however, is not Achilles' rage as in the Iliad but his glory."

25 The positive presentation of the Trojans corresponds to the rather negative characterization of the Greeks that focuses on Agamemnon and some of the soldiers. Other Greeks like Odysseus, Nestor, Patroclus, or Ajax are shown positively and are sometimes even likeable. Menelaus only becomes a revengeful cuckold when Helena runs away with Paris. Before, he is a king who wishes peace with the Trojans. 
vant of Apollo. King Priam immediately clarifies for the audience that "the young men of Troy were devastated when Briseis chose the virgin robes." On this occasion all Trojans wear turquoise clothes (see above). Only Briseis is dressed in a white robe and veil, which underscores her virginity. ${ }^{26}$ In the darkness of Achilles' tent, which reflects his introverted character, she wears the same robe now while sitting on the ground, bound to a pole, her lips bleeding. Briseis attracts Achilles' attention only after his adjutant Eudorus points out that she was put there for his "amusement." Taking a closer look at her while undressing himself, he asks for her name. Briseis now glances at Achilles for the first time. Instead of telling him her name she condemns the murdering of the priests and calls him a killer. The ground-view camera shows her to us seated in the foreground as Achilles stands upright in the background. The opposing camera angle originates from the perspective of Achilles' eye: Briseis sits in front of a bag overflowing with plundered gold objects to remind the audience of her captivity. Neither her tough and brave behavior, nor Achilles' nudity, which contrasts with her virgin robes, correspond at all to this novel tableau. ${ }^{27}$

A minute later, Achilles, now wearing a wrap-around loincloth, moves much closer to Briseis. He moves so close to the camera behind her that his view angle becomes much steeper. This perspective of him looking down on her is used to frame a dialogue that would seem to take the opposite frame, for after touching and smelling her hair he assumes that she must be of royal blood because of the haughty manner in which she speaks - as one in high position speaks to subordinates. He asks for her name; in fact, he asks for her name twice, which emphasizes that for him she is not just booty but a human being. She refuses to give him an answer until Achilles cuts her bonds and crouches down next to her. Now eye-toeye with him, Briseis finally introduces herself. In response to his asking her if she is afraid, she now looks up at him slightly and answers with the question, "Should I be?". Her anxious voice and her wounded lip point up the real balance of power between them. After a brief interruption by Eudorus, they resume the conversation on eye-level again.

Briseis: What do you want in Troy? You didn't come for the Spartan queen. Achilles: I want what every man wants; I just want it more.

Briseis slightly averts her gaze from him. Calling her "girl," he tells her that she is the only person from Troy that does not have to fear him.

${ }^{26}$ Cf. Alena Allen, "Briseis in Homer, Ovid and Troy," in Winkler, Troy, 148 and 156.

27 Cf. Allen, "Briseis in Homer," 157. 
The interruption by Eudorus was to summon Achilles to Agamemnon's tent, where a few minutes later Achilles is engaged in a verbal fight with the king. The argument climaxes when Agamemnon shocks Achilles by having two of his soldiers drag Briseis into the scene. She has a bleeding nose and is crying. The camera focuses now on the appalled face of Achilles. Everything would seem to be leading to a violent resolution, but Briseis abruptly speaks out:

Stop! Too many men have died today. If killing is your only talent, that's your curse. I don't want anyone dying for me.

It is remarkable that she, as a captive, influences the course of action by terminating the fight. It is even more impressive that Achilles, who was just going to kill his compatriots, listens to Briseis. ${ }^{28}$ Agamemnon, amused, remarks: "Mighty Achilles, silenced by a slave girl." As a result she stays in Agamemnon's tent, and Achilles, deeply offended, refuses to participate in any subsequent battles. After a military defeat, Agamemnon, without having touched her, turns Briseis over to his soldiers. When one of them tries to brand her with a hot iron, she fights back by slapping him. At the very last minute Achilles appears, kills two of the offending Greeks, and carries Briseis, who has fainted, to his tent. Achilles, who admires her courage, tries to wash her face with a wet cloth but she interferes twice by beating him. He throws the cloth into her face, she throws it back at him; after he gives up trying to clean her, she takes the cloth herself. While he looks down at her and she looks up at him, she asks if he likes provoking her. Instead of providing an answer he just smiles what might be considered a positive response. The scene ends with Briseis' comment on Achilles' opinion about the gods:

I thought you are a dumb brute. I could have forgiven a dumb brute.

She does not agree with what he said but she has now understood that Achilles is more profound than she first supposed. ${ }^{29}$ As in the scene before, Briseis is visually portrayed as a victim, but this visual representation is not consistent with her tough and self-confident behavior. This is precisely what makes her so interesting for Achilles, who does not even

28 In Homer' Iliad (1.193-222) it is the goddess Athena who prevents Achilles from killing Agamemnon. Cf. Allen, "Briseis in Homer," 158; Jon Solomon, "Viewing Troy: Authenticity, Criticism, Interpretation," in Winkler, Troy, 97.

29 Cf. Allen, "Briseis in Homer," 159; Joachim Latacz, "From Homer's Troy to Petersen's Troy," in Winkler, Troy, 41-42. 
try to touch her. ${ }^{30}$ Their relationship is portrayed as one of equals. ${ }^{31}$ His conduct towards Briseis differs from the other Greeks' attitudes towards women. According to the genre-typical usage of binary oppositions, the "bad guys" regard women as an object of pleasure. Agamemnon considers Briseis his booty, and his brother Menelaus wants his wife Helen back in order to restore his honor and recover his decorative possession. For Achilles, Briseis is a counterpart. After he has rescued her from the Greek soldiers, she approaches him while he is sleeping and holds a dagger to his throat. The captive could free herself and kill the most dangerous of the hostile warriors. Achilles wakes up and even encourages her to stab him. She cannot go through with it, and Achilles grabs her and throws her on her back. The assassination attempt quickly evolves into a love act during which Briseis still holds the dagger - as some kind of phallus symbol - at Achilles' throat for some time. The petite woman needs the weapon to match the mighty warrior. But finally the virgin is overpowered by Achilles' masculinity. The tough girl is domesticated. The emotionality attributed to women triumphs over rationality.

Interestingly, this scene corresponds with a similar one in Oliver Stone's Alexander (2004) which was released six months after Troy. There the Bactrian noble Roxana tries to kill her husband Alexander on their wedding night, also by threatening the man with a dagger. Just as Achilles is an enemy of Briseis' people, the conqueror Alexander is an enemy of the Bactrians, so that in both films the women could have freed their homelands from grave danger. But in both instances even the unarmed man is superior to the armed woman, and the assassination attempt ends up in a love scene. One significant difference between the two love scenes is that Roxana in Alexander is depicted as unfettered and wild, particularly in the erotic scene which features the naked Alexander and Roxana acting out an extraordinary realization of a clash of cultures. The love scene between Achilles and Briseis is more romantic and tender, and what stands out is Achilles' nudity - a stark juxtaposition with Briseis, who is still wearing her white robe. As mentioned before, it is Achilles who is staged in the traditional female way. In the morning Briseis finally appears nude in the bed, but she is covered by a black blanket. The black color may be intended to symbolize a new unity with Achilles, whose distinctive ship

30 Cf. Allen, "Briseis in Homer," 149.

31 Cf. Ibid., 157. 
is unique amidst the white-sailed Greek fleet by having a black sail. ${ }^{32}$ Following this analogy, Briseis belongs now to Achilles. The latter sits next to her gazing thoughtfully at the peaceful, sleeping woman. He is dressed in turquoise now, the color he wore in his homeland during the peacetime, suggesting that the war is over for him and that he has found peace in the relationship he has now developed with this woman. And indeed, Achilles now decides to sail home. He tamed the proud virgin, and Briseis domesticated the mighty warrior. ${ }^{33}$

During the next night they appear together in bed, she nestles up against him while he is holding her in his strong arm. Although they are presented more or less on an equal footing, the man definitively assumes the traditional role of the protector. For example, while they are sleeping the camera shows that he is holding her from behind. In another scene she looks up at him and he down at her as he asks if she is willing to leave Troy, which means, in an indirect way, that he is asking if she can imagine leaving together with him. Briseis does not answer the question but breathes heavily and puts her hand on his shoulder.

Everything could have led to a happy end if Hector had not killed Patroclus, mistaking him for Achilles. When Eudorus delivers to Achilles the shocking news about his cousin's death, the latter turns completely wild and first threatens to kill Eudorus and then grabs Briseis - not wearing her virgin robe any longer - by her throat when she tries to interfere. He holds her up in the air - his posture resembling an ancient statue - while his foot is pressing hard against the throat of Eudorus, who is lying on the ground, spitting blood. Shortly before Briseis loses consciousness, Achilles manages to control his anger and stops acting so violently. His rage and pain have reversed his domestication, and the thirst for revenge dominates his thoughts. ${ }^{34}$

In the subsequent sequence in which Briseis tries to make Achilles spare her cousin Hector's life, Achilles stands upon his chariot, raising his position to a much higher level than hers, and consequently she looks up at him in a very steep angle. However, her words cannot reach the fearless warrior any longer. Achilles leaves without saying anything and ultimately kills Hector. Once again, Achilles' characterization as individu-

\footnotetext{
32 In Homer's Iliad all ships are described as being black. Here, only the vermilion red boat of Odysseus is an exception (Hom. Il. 2.493-76o).

33 Cf. Allen, "Briseis in Homer," 159; Shahabudin, "From Greek Myth to Hollywood Story," 115 .

34 Cf. Allen, "Briseis in Homer," 160.
} 
alist and rule-breaker is realized on screen. ${ }^{35}$ He desecrates the corpse of Hector, breaking broadly accepted human conventions.

During the night King Priam comes secretly to his tent, and after talking to Achilles, Priam brings him back to his senses. Achilles requests that Briseis follows her uncle back to Troy. Before she leaves, looking back at him several times, Achilles says:

If I have hurt you, it is not what I wanted.

As a goodbye present Achilles gives Briseis a necklace he received from his mother Thetis. Since he had given the same necklace earlier to Patroclus, the gesture emphasizes how much Briseis means to him. ${ }^{36}$ But Achilles does not give up on her. He joins the Greeks sitting in the wooden horse and enters Troy ultimately to save her life. Achilles again fulfills his role as protector. After looking desperately for her - his search appears to be brief sort of odyssey - he rescues her once again shortly before some Greek soldiers are about to kill her. For the second time a happy ending for the two seems to be well within reach until Paris appears and kills Achilles with several shots from his bow. While dying Achilles takes Briseis' face into his hands and tries to calm her down. Just before she is forced to leave the city in order to save herself, he concludes:

You gave me peace in a lifetime of war.

\section{The Hero and His Relationships: Hector the Family Man}

Hector represents quite the opposite of Achilles. He is a married man who dedicates his life to the protection of Troy and his family. In spite of his being an extremely capable military leader and the greatest warrior of Troy, warfare has nothing glorious for him. ${ }^{37}$ It is because of his family responsibility that he finds himself the antagonist of Achilles, the adventurer in search for glory. He abhors killing the defenseless and makes sure that all civilians living outside Troy are brought behind its enormous walls for their protection. Unlike the maverick Achilles, he is very well integrated

\footnotetext{
35 Achilles is presented as a maverick in several scenes. Cf. Wieber, "Vor Troja nichts Neues?" 158.

36 Cf. Allen, "Briseis in Homer," 160.

37 This is a parallel to Maximus (Russell Crowe), the protagonist of Gladiator (2000). Cf. Anja Wieber, "Hauptsache Helden? Zwischen Eskapismus und Identifikation - Zur Funktionalisierung der Antike im aktuellen Film," in Martin Korenjak and Karlheinz Töchterle, eds., Pontes II. Antike im Film (Innsbruck: Studien Verlag, 2002) 15-16.
} 
in his social environment, and he is often shown together with his family or with his people - to illustrate how meaningful family is to him. The film introduces him to the audience while he is sitting next to his brother Paris during their diplomatic mission to Sparta. A few minutes later he refuses a woman offered to him by King Menelaus, explaining that his wife is waiting for him in Troy. Afterwards he is frequently shown together with his wife and his infant son or watching over his son's cradle.

When he returns from Sparta, the inhabitants of Troy offer him the aforementioned welcome celebration. Shortly before Briseis is introduced, Hector's wife Andromache appears for the first time on the screen. She enters the scene from the background on the left and slowly nears her husband, the back of whose head is centered by the camera so that we see Andromache from the same perspective as he does. She tenderly looks up at him with her big brown eyes. The baby in her arms identifies her as the wife Hector spoke about in Sparta. The scene ends showing the couple gazing happily at their son. Quite differently from the introduction of Briseis, here the audience does not know her name until the end of the film. Therefore she is reduced to the role of Hector's wife.

A few minutes later we visit the family in its private residence in the palace. Hector, wearing his own wrap-around robe, exercises his role as protector of the family as he sits topless on the bed holding his son in his muscular arms. Furthermore, this image reveals, alongside his warmth and affection, perhaps a bit of vulnerability. This time Andromache comes from the right and mounts some stairs before she reaches the bed and looks down at them happily. The higher position of the bed conveys the high value of the family. The room is spacious and bright, contrasting with the dark tent of Achilles. It is not a closed room; only pillars separate it from a balcony open to the seaside. No word is spoken in this scene that exhibits Hector's idyllic family life. But this harmony is about to be disturbed since the scenes before and afterwards display war preparations and sacrifices for Apollo. The background music changes to a more hectic one, intensified by the marching soldiers with their long spears. Suddenly an alarm signal is given by the soldiers and we see Andromache looking with fright to a point next to the camera, probably the seaside. Hector appears next to her with a grave countenance. From the balcony he sees the huge Greek fleet approaching the city.

After the first day of fighting, Hector and Andromache sit together on their bed. The cradle stands directly in front of them. Because the room is now illuminated by torches, the atmosphere is much more sober. Hector is deeply impressed by his first contact with Achilles and shares his impres- 
sions with his wife. Extraordinarily, his face is shown looking up at her slightly, while the audience sees him from the ground-camera's perspective. Andromache, filmed from the same perspective, looks down at him begging him not to fight. Because of the camera angle, Hector is shown at least on an equal position although he is sitting and she is standing. Her request to him not to join the fight discloses her presentiment of what is about to occur, so again the woman serves as a symbol for emotionality whereas the man stands for rationality. The prince and commander-inchief has no other choice, so she is depicted as the anxious housewife who has no deeper understanding of her man's duties. We notice as well that Hector shares his thoughts and sorrows with her without receiving any feedback, additional evidence of her passive role. ${ }^{38}$ While they are talking, the camera centers on the baby to underscore their sorrows and the insecurity of their future. Hector reminds his wife of his duties but admits to her that he actually does not want to leave:

You know I don't want to fight. I want to see my son grow tall. I want to see the girls chasing after him.

This confirmation of Hector as a family man provides still another boost to the film's postulated heteronormativity. ${ }^{39}$ Andromache reminds him of her seven brothers lost in the Spartan Wars and points out she could not stand losing him as well. The scene displays her devotion to Hector and the reasons for her deep fear. ${ }^{40}$ She starts crying, and Hector leaves the room after kissing her without saying a word. He is the protector of the family but at the same time responsible for the whole city of Troy. The obligations required by his status as the crown prince come before his private happiness. Andromache is portrayed in an old-fashioned way as "just" a scared housewife who is proud of her husband. The contrasting description of Hector and Andromache reconstructs once more the gender dualism. ${ }^{41}$

38 One of the central aspects of Mulvey's theory is her criticism of the passive role of women in films. Cf. Mulvey, "Visuelle Lust und narratives Kino," passim.

39 In the Iliad Hector wishes that his son Astyanax will become like him, maybe even better, and imagines him coming home covered with the blood of a slain opponent for the joy of his mother (Hom. Il. 6.477-481). Cf. Wöhrle, Telemachs Reise, 91-92.

40 The scene corresponds to the Iliad in which Andromache asks Hector not to fight and reminds him of the death of her father and her seven brothers (Hom. Il. 6.407-439).

41 The attributes ascribed to Andromache and Hector reflect female and male stereotypes that were identified by Williams and Best. According to their study, stereotype items describe women as, for example, anxious, dependent, emotional, fearful, and whiny, whereas men are connoted with adjectives like active, courageous, forceful, or logical. Cf. 
After killing Patroclus instead of Achilles, Hector seems profoundly changed. ${ }^{42}$ Because he is sure that Achilles will take revenge, in a night scene he shows Andromache a secret way out of the city. He does this to assure himself that his family will be saved if he should prove unable to protect them anymore. Later that same night, the worried Hector is shown standing in his room, looking at his son's cradle. Andromache is lying on the bed asleep, but her posture is that of a crying woman. A crosscut scene the next morning shows Hector and Achilles putting on their armor. Compared to the energetic Achilles, Hector is shown as hesitant in the foreground, while the cradle and his sleeping wife can be seen in the background. ${ }^{43}$ When he leaves the room Andromache wakes up and watches him leave without saying a word. In the palace Hector says goodbye to his family and his friends as if he knew already he would not survive the fight. Ultimately his wife arrives with their son, and he reminds her of the secret exit. A final close-up shows him kissing the forehead of his son while Andromache puts her chin on the back of the boy's head. For a last time the family is shown in unity. As an omen of Hector's death, the infant starts to cry.

\section{Conclusion}

As mentioned at the outset, Achilles and Hector both correspond to Connell's model of hegemonic masculinity. What makes it extremely remarkable is that Achilles' depiction alternates between the traditional male and female staging. First, according to their roles as the mightiest warriors of their armies, they are both the protectors of their beautiful female partners. ${ }^{44}$ On one side we see the serious, dutiful, and responsible Hector fully integrated into his social environment, and on the other Achilles, the lonely wolf, who refuses to conform to the Greeks' value system. ${ }^{45}$ If we spoke about Westerns, whose storylines clearly follow in the tradition of Homer, Achilles would represent the outlaw, the lonely rider, or the gunslinger, while Hector would be the sedentary farmer or the duteous

John E. Williams and Deborah L. Best, Measuring Sex Stereotypes: A Multination Study (Beverly Hills: Sage Publications, 1990).

42 Cf. Kofler and Schaffenrath, "Petersens epische Technik," 329.

43 Cf. Ibid., 329-330.

44 This corresponds to the genre's conventions. Cf. Wieber-Scariot, "Film," 1137.

45 According to this description, Hector faces the combat with Achilles although he foreshadows his own death and follows the aristocratic code by doing so. On the contrary, Achilles disgraces the latter's corpse and thereby violates the conventions. 
sheriff. ${ }^{46}$ Another cliché is Achilles' domestication by a woman. If he had not been killed we could imagine him establishing a family and becoming Hector's double.

Interestingly, the filmmakers give both men their female counterparts as partners. Like Achilles, Briseis refuses to establish a family when she chooses the life of a virgin priestess. When she is a captive she does not behave like one but, on the contrary, acts tough and with self-confidence. She has opinions of her own and does not hesitate to express them. Achilles is attracted to her precisely because of these attributes. She represents a challenge to him, which is emphasized by her plans of remaining a virgin for life. They both have strong personalities that challenge and want to be challenged. ${ }^{47}$

Andromache falls under a slightly old fashioned image of the perfect housewife who takes care of her house and family while her husband Hector fulfills his obligations. She is devoted and reliable - just like her husband. Most of the time she is shown with a grave face, which correlates to Hector's worried countenance. She does not express her own opinions except for begging her husband not go to war. To support this characterization, her name is mentioned for the first time only a few minutes before the end of the film. She is not depicted as a remarkable character but only as Hector's wife. Nevertheless Hector confides in her, sharing with her his burdens. ${ }^{48}$ The relationships we have described mirror the different characters of Achilles and Hector.

Although they perform in an ancient setting, Achilles and Hector represent current types of Western masculinities. This brings up an important question: to what kind of values and standards in the real world do the represented masculinities and the narrative structures in the film refer? As the protector and provider of his family Hector approximates the modern image of man who confides in his wife about his work-related problems and personal sorrows and contributes to the familial well-being by providing quality parenting for his son. The filmmakers might have constructed

46 Cf. André Bazin, "Der Western oder: Das amerikanische Kino par excellence," in Bert Rebhandl, ed., Western. Genre und Geschichte (Vienna: Zsolnay, 2007) 40.

47 Briseis's personality in the film is much more complex than in the Iliad because the filmmakers conflated her with several other characters from Greek mythology, like Cassandra, Polyxena, Clytemnestra, and the goddess Athena. Cf. Allen, "Briseis in Homer," 158, 160-161; Solomon, "Viewing Troy," 97.

48 Particularly in comparison to the Homeric Hector and his relation to Andromache: "Nay, go thou to the house and busy thyself with thine own tasks, the loom and the distaff, and bid thy handmaids ply their work: but war shall be for men, for all, but most of all for me, of them that dwell in Ilios." (Hom. Il. 6, 490-493). 
him as a role model for an adult audience that has already begun a family and achieved something in life worthy of being defended. ${ }^{49}$

The philosophy of life Achilles outlines at the beginning of the film does not include the aspiration of fathering a family, and his disputes with Agamemnon may well represent intergenerational conflict. ${ }^{50}$ On account of his love for Briseis, he reconsiders his judgment and apparently is willing to enter a relationship. The development of his character follows a current trend in our contemporary society - to postpone having a serious relationship and follow individualistic goals in life. ${ }^{51}$ The filmmakers might have constructed Achilles as a role model for a younger audience that is still unbound and adventurous.

As we see, the filmmakers, in producing Troy, did the same as Homer had done before: they took an old epic story and adapted it to their own times. ${ }^{52}$

\section{Works Cited}

Allen, Alena. "Briseis in Homer, Ovid and Troy," in Martin W. Winkler, ed., Troy: from Homer's Iliad to Hollywood Epic (Malden, MA: Blackwell, 2007).

Bazin, André. "Der Western oder: Das amerikanische Kino par excellence," in Bert Rebhandl, ed., Western. Genre und Geschichte (Vienna: Zsolnay, 2007) 40.

Butler, Judith. "Leibliche Einschreibungen, performative Subversionen," in Das Unbehagen der Geschlechter (trans. Kathrina Menke; Frankfurt am Main: Suhrkamp, 1991) 190-208.

Connell, Raewyn. Masculinities (Berkeley and Los Angeles, University of California Press, 2005).

Connell, Robert W. "Arms and the Men: Using the New Research on Masculinity to Understand Violence and Promote Peace in the Contemporary World," in Ingeborg Breines, Raewyn Connell, and Ingrid Eide, eds., Male Roles, Masculinities and Violence: A Culture of Peace Perspective (Paris: UNESCO, 2000) 21-31.

- Der gemachte Mann. Konstruktion und Krise von Männlichkeiten (trans. Christian Stahl; Opladen: Leske und Budrich, 1999).

Denzin, Norman K. "Reading Film - Filme und Videos als sozialwissenschaftliches Erfahrungsmaterial," in Uwe Flick, Ernst von Kardorff und Ines Steinke, eds., Qualitative Forschung. Ein Handbuch. (Reinbek bei Hamburg: Rohwolt, 2000) 416-428.

Gödde, Susanne. "Achilleus," in Der Neue Pauly, suppl. 5 (2008).

49 Wieber supposes in respect to Gladiator (2000) and The Patriot (2000) that the emphasis on family values satisfies the longings of the contemporary audience living during a period often characterized by singles and patchwork families. Cf. Wieber, "Hauptsache Helden?" 16.

50 Cf. Wieber, "Vor Troja nichts Neues?" 158-159.

51 Cf. St. Hradil, Die Single-Gesellschaft, Munich 1995.

52 Cf. Manfred O. Korfmann, "Was there a Trojan War? Troy between Fiction and Archaeological Evidence," in Winkler, Troy, 21; and Latacz, "From Homer's Troy to Petersen's Troy," 41-42; cf. "Vor Troja nichts Neues?" 162. 
Hall, Stuart. "Encoding/decoding," in Centre for Contemporary Cultural Studies, ed., Culture, Media, Language: Working Papers in Cultural Studies, 1972-79 (London: Hutchinson, 1980) 128-138.

Kofler, Wolfgang and Florian Schaffenrath. "Petersens epische Technik: Troja und seine Homerische Vorlage," in Stefan Neuhaus, ed., Literatur im Film: Beispiele einer Medienbeziehung (Würzburg: Königshausen \& Neumann, 2008) 313-330.

Korfmann, Manfred O. "Was there a Trojan War? Troy between Fiction and Archaeological Evidence," in Winkler, Troy.

Lindner, Martin. Rom und seine Kaiser im Historienfilm (Frankfurt am Main: Verlag Antike, 2007).

Mulvey, Laura. "Visuelle Lust und narratives Kino," 30-46 in Gertrud Nabakovski, Helke Sander, and Peter Gorsen, Frauen in der Kunst (Band I, Frankfurt am Main: Suhrkamp, 1980 ).

Neale, Steve. "Masculinity as Spectacle: Reflections on Men and Mainstream Cinema," in Steven Coham and Ina Rae Hark, eds., Screening the Male: Exploring Masculinities in Hollywood Cinema (London: Routledge, 1994) 9-20.

Shahabudin, Kim. "From Greek Myth to Hollywood Story, Explanatory Narrative in Troy," in Winkler, Troy.

Weingarten, Susanne. Bodies of Evidence: Geschlechtsrepräsentationen von Hollywoodstars (Marburg: Schüren, 2003).

Wieber, Anja. "Antike am laufenden Meter: Mehr als ein Jahrhundert Filmgeschichte," in Mischa Meier and Simona Slanicka, eds., Antike und Mittelalter im Film: Konstruktion Dokumentation - Projektion (Köln: Böhlau Verlag, 2007).

_. "Hauptsache Helden? Zwischen Eskapismus und Identifikation - Zur Funktionalisierung der Antike im aktuellen Film," in Martin Korenjak and Karlheinz Töchterle, eds., Pontes II. Antike im Film (Innsbruck: Studien Verlag, 2002).

_ _. "Vor Troja nichts Neues? Moderne Kinogeschichten zu Homers Ilias," in Martin Lindner, Drehbuch Geschichte: Die antike Welt im Film (Münster: LIT, 2005) 137-162.

Wieber-Scariot, Anja. "Film," in Der Neue Pauly 13 (1999).

Williams John E. and Deborah L. Best. Measuring Sex Stereotypes: A Multination Study (Beverly Hills: Sage Publications, 1990).

Winkler, Martin M. ed., Troy: from Homer's Iliad to Hollywood Epic (Malden, MA: Blackwell, 2007).

Winter, Rainer. "Film und gesellschaftliche Wirklichkeit. Zur Aktualität der Filmsoziologie," in Jutta Allmendinger et al., eds., Entstaatlichung und soziale Sicherheit. Verhandlungen des 31. Kongresses der Deutschen Gesellschaft für Soziologie (Opladen: Leske und Budrich, 2004) 112-116.

Wöhrle, Georg. Telemachs Reise. Väter und Söhne in Ilias und Odyssee oder ein Beitrag zur Erforschung der Männlichkeitsideologie in der homerischen Welt (Göttingen: Vandenhoeck \& Ruprecht, 1999) 85-98.

Zurstiege, Guido. "Fit und flott - und ein wenig sexy in schwarz-weiß, die strukturelle Ambivalenz werblicher Medienangebote," in Christina Holtz-Bacha, ed., Stereotype? Frauen und Männer in der Werbung (Wiesbaden: VS Verlag für Sozialwissenschaften, 2008) 107-123. 



\title{
"INCLUDE ME OUT" - ODYSSEUS ON THE MARGINS OF EUROPEAN GENRE CINEMA: LE MÉPRIS, ULISSE, L'ODISSEA
}

\author{
Christian Pischel
}

\section{The Diagram}

Homer's Odyssey is considered one of the founding documents of European literature. As we know, the text intertwines the motifs of the odyssey or epic voyage, the intended homecoming, which is constantly being delayed and prevented by temptations and perils, and a structurally analogous narrative. Just as Odysseus traverses the world several times in search of Ithaca, the epic poem unites several temporal levels, narrative voices, and points of view until his return home, where the narrative does not end but culminates in the renewed and condensed mirroring of the entire process, the texture in all its to and fro and back and forth: Athena extends the night so that the reunited couple may tell each other the story of their twenty-year separation. Theresia Birkenhauer writes: ${ }^{1}$

The Odyssey is as artfully told as the narration is emphatically addressed in the epic. The hero's labyrinthine parcours through uncanny spaces finds expression in the equally varied forms of discours, of narrative.

In what follows, the epic quality of the material will serve as a backdrop against which I will explore three cinematic adaptations of the Odyssey. The films are the major Italo-American co-production Ulisse (Ulysses, 1954) directed by Mario Camerini, which is remembered today mainly because it starred Kirk Douglas, Le Mépris (Contempt, 1963) by Jean-Luc Godard, and a lesser-known eight-part television miniseries from 1968 entitled L'Odissea directed by Franco Rossi. Based on the dates alone and read against the cycles of film history, these films are strikingly grouped around a distinct period in the history of European cinema. These three productions mark the era of the epic and sword-and-sandal (peplum) film, which, from the mid-1950s to the mid-196os, attracted international attention for the second time in Italian film history. While in the 1910s the

\footnotetext{
1 Theresia Birkenhauer, "Episches Erzählen - ein Erfahrungsraum," program for Isabel Mundry, Ein Atemzug - die Odyssee, Deutsche Oper Berlin, 2005/2006 Season. 
genre had already become a dominant product on the international market in the form of hugely elaborate and costly feature films, it returned as a low-budget mass product after Pietro Francisci's 1958 Le Fatiche di Ercole (Hercules) unexpectedly became one of the highest grossing films of the year. Cheaply produced successors followed certain patterns, series, and variations, whose shared characteristics Richard Dyer tersely described as follows: ${ }^{2}$

Peplum films are adventure films centred on heroes drawn from classical (including Biblical) antiquity played by US bodybuilders.

The concept of the male hero and the casting alone already reveal a significant difference between the Homeric epic and the aforementioned film versions. If we examine the historical formation of the genre and insert the adaptations of the Odyssey, what emerges is the diagram of a repeated, reciprocal mismatch. Ulisse, despite its international cast and high budget, did not unleash the wave, but preceded it by several years. Le Mépris, made at the peak of the genre, expresses itself in strongly self-reflexive changes of level, which place the genre, antiquity, and also gender tensions in quotation marks to the point of alienation. And for television L'Odissea shifts to a serial format, at a time when, as the film historian Pierre Sorlin has shown, the Italo-Western had long since supplanted the epic film. ${ }^{3}$ "Include me out" appears to be Odysseus's position on the genre.

The present essay seeks to describe these films in the constellation between the Homeric epic on the one hand and genre film on the other, and to use these reciprocal relationships to reveal the significant marginality of the Odyssey adaptations within genre film. All of the examples are grouped around the genre, but each of them deviates from it in its own way, and this deviation unfolds, as we will see, as a reflection on the relationship between narrative, gender tensions, and subjectivity. Thus each film will be queried as to its specific model of the epic and correlating concept of the subject. As we will see, the reason the films miss the mark lies in the mismatch between genre cinema's hyperbolic masculine acting subject and the ambivalent subjectivity of the Homeric figure of Odysseus. This cannot be explained solely on the level of narrative, however, in a purely representative reading of the hero, for example, but emerges only in the question of the concept of the epic that each film projects.

2 Richard Dyer, White: Essays on Race and Culture (London, 1997), p. 165.

3 Pierre Sorlin, "Die Genrefilm der 196oer Jahre. Kolossalfilm und Western," in Das goldene Zeitalter des italienischen Films. 196oer Jahre, ed. Thomas Koebner and Irmbert Schenk (Munich, 2008) 371-90. 
With reference to their respective film-aesthetic processes, the productions cited here can only be interrogated as to how they themselves create a reflection on the announced context. For that reason, the focus is less on the plot, the "eloquent" scenes, or character delineation; the following analysis of the films is intended to develop and elucidate a picture of the cinematic form and show how the aesthetic possibilities of film and television were used to express a notion of the epic.

\section{Ulisse (1954)}

When Mario Camerini made Ulisse in 1954 the response was positive, but far removed from the prototypical status achieved three years later by Pietro Francisci's Le Fatiche di Ercole, which offered a full realization of Dyer's definition: Steve Reeves, who had had a successful career as a bodybuilder before turning to acting, embodied the stereotypical strong man and thus put his stamp on the figure of Hercules, which would represent the stable axis of the further development of the genre. Even past the apogee of the genre in the mid-196os, it was heroes such as Hercules, Samson, and Maciste (a legendary figure invented by Gabriele D'Annunzio) who strutted their poses and feats of strength on the pseudo-antique stages of the Italian sword-and-sandal films, displaying their muscle mass and virile agency in exhibition battles.

Odysseus, in contrast, is portrayed less as a muscle man than as a scrupulous but passionate adventurer, whose contradictory yearnings - for the unknown, on the one hand, and for home and hearth on the other must be pacified. From the perspective of the Homeric Odyssey, one is tempted to regard this as a forceful handling of literary complexity. In genre film, however, it is an impressive testament to the integrative power of Hollywood, the capacity to mold heterogeneous material into apparently originless narrative, which draws the impetus for events solely from the story itself. The narrative process retreats behind the opulence of the depicted world or is tied to the diegetic figures. In this sense, Hans Blumenberg describes the realistic legacy of the epic as the restraining of its narrative quality. ${ }^{4}$

Since Homer, the epic has been the genre devoted to absorbing the world, to putting oneself in the place of the world according to the abundance und degree of reality, in order to gather wholly unto oneself the intensity of relationships to reality.

\footnotetext{
${ }^{4}$ Hans Blumenberg, Die Lesbarkeit der Welt (Frankfurt am Main, 1981) 222.
} 
It is doubtful whether Homer's Odyssey in particular stands for this type of realistic illusionism with the epic polyphony described by Birkenhauer, but there is no question that within the epic's books, the density of the narrated world repeatedly works against the narrative process. This dimension - the worldliness of the epic - meets the aesthetic potential of the classic Hollywood film to provide a positive image of the world even on a large scale and to relate it to the emotional life of its protagonists. In short, it is a realism that, like the wandering seafarer, is capable of traversing the entire world. Unlike epic poetry, which starts by invoking the Muses, so that the events may be told, Ulisse begins with the antagonism between world and desire within the diegesis - the absence of Odysseus from his appointed place, which supplies the basic dramaturgical tension for the whole film.

In the first shot, we see the spinning maids, admonished by Eurycleia, being dismissed for the night. In the reverse shot, Penelope rushes into the room wearing a flowing black veil and reports that she has spied the vague outlines of a ship in the twilight. Odysseus's nursemaid interprets her hopeful words: what she saw is a function of her longing, at which point Penelope's touching gaze moves in all directions, until the laughter of the suitors can be heard from off-screen. A situation becomes concrete and is immediately applied to the unfulfilled wishes and tribulations of a sensitive female soul. What is expressed here evolves over the course of the film into the melodramatic image of a lonely woman whose tears over the unknown fate of her husband turn into the soft-focus veil of her own close-up.

Ulisse continues with this logic, qualifying its images as outward circumstances or inner states and setting them in dynamic relation to one another so that the world, whether as resistance or fulfillment, is related to the protagonist's emotional life. The characters function as an impetus for the action-images, personalize the memory-images, and put the affection-images in perspective. From within, the diegetic world projects itself as a hall of mirrors, in which desire and law are constantly modulating one another, and to which a psychoanalytic interpretation has a purely reconstructive relationship: the sirens tempt Odysseus with the voice of Penelope; Circe presents herself as a variant of all women, but appears as the blonde version of his wife; 5 the mother in the realm of the dead admonishes his return; and archaic law appears in the form of the hyper-

5 Silvana Mangano plays both Penelope and Circe. 
masculine Cyclops. The epic operates within the boundaries set out by the cathartic tale of a conflicted soul; epic poetry's power to open up the world is translated into the reflected images of a desiring male subject, to which Penelope's tears respond. In this sense, gender binarism is incorporated into the tension that carries the entire narrative arc and conceives of the topos of homecoming as the reunification of originless, reciprocally gendered souls, in keeping with the matrix of monogamous marriage.

Naturally, the episode with Polyphemus also undergoes a corresponding transformation: Odysseus must not deny his identity. No "mimicking the amorphous" preserves him, as Adorno and Horkheimer put it. ${ }^{6}$ Neither does Odysseus cling to the woolly underbelly of the ram in order to escape the Cyclops' cave, nor does he have to resort to the insipid wordplay whose interpretation the Dialectic of Enlightenment unfolds: ${ }^{7}$

In the Greek version it is a play on words; in a single word the name - Odysseus - and the intention - nobody - diverge. To modern ears Odysseus and Udeis still sound similar, and it is conceivable that in one of the dialects in which the story of the return to Ithaca was handed down, the name of the island's king did indeed sound the same as "nobody." The calculation that, once the deed was done, Polyphemus would answer "Nobody" when the tribe asked who was to blame, thus allowing the perpetrator to escape pursuit, is a thin rationalistic screen. In reality, Odysseus, the subject, denies his own identity, which makes him a subject, and preserves his life by mimicking the amorphous realm.

In the film, however, the mastery of higher powers remains tied to being "somebody." While Homer's work highlights the capacity to negate and position oneself, the film exclusively emphasizes the self-identity of the acting subject: Odysseus, back on the ship after a successful ruse, mockingly and boastingly dares to call out not just his name but also his descent and homeland. But it is not simply his proud name, which marks him as an acting male subject, nor his athletic figure, which precisely locates him between the effeminate Phaeacians and the testosterone-loaded god's son Polyphemus. The film removes all ambiguity from the protagonists and not merely on the level of representation; a further aspect of the figure of Odysseus becomes clear against the backdrop of the Homeric epic. As Adorno and Horkheimer note, ${ }^{8}$

\footnotetext{
${ }^{6}$ Max Horkheimer and Theodor W. Adorno (Gunzelin Schmid Noerr, trans.), The Dialectic of Enlightenment: Philosophical Fragments (Stanford CA: Stanford University Press, 2002), 53 .

7 Horkheimer and Adorno, Dialectic of Enlightenment, 53.

8 Ibid., 61.
} 
It is in the self-reflection which causes violence to pause at the moment of narrating such deeds. Speech itself, language as opposed to mythical song, the possibility of holding fast the past atrocity through memory, is the law of Homeric escape. Not without reason is the fleeing hero repeatedly introduced as narrator.

The escapee of Homer's Odyssey tells a story, narrating himself and his own tale, reconstituting himself as the polymorphous, manifold, and undifferentiated entity that has emerged only painfully. The cinematic Odysseus, however, is only threatened with disintegration in retrospect, and undergoes no self-formation in the loss of self. Thus the story of his odyssey, too, is not a tale such as that told in the epic of the Phaeacian King Alcinous. Instead, it comes into play as a flashback to his memories, at the very moment when the Phaeacian physician suggests to him the possible identity of hero, since he has been suffering from amnesia since the shipwreck. Lost in thought, he looks out to sea, answers his wife's tearful gaze, and relives the odyssey in his mind. And yet it is not his own voice that begins to tell the story, but autonomous recollection, which had already left him when he lost his memory and now returns as a claim to reality. In this sense his subjectivity remains solely on the level of the story. There is no doubt that it generates desires and ruses, but no narrative of itself. As sprawling as the parcours of Ulisse is, the discours unfolds here solely from the tension between the gendered souls, who like the traversed world have become the subject matter represented by the film.

\section{Le Mépris (1963)}

The film tells the story of a couple, Paul and Camille, who are drawn into a film production: the adaptation of Homer's Odyssey by Fritz Lang. There is much to indicate that Godard's film version of Alberto Moravia's novel Il disprezzo (Contempt) should not be understood solely in the context of auteur and œuvre or the tension between literature and film. Among the film's many allusions, one, I believe, is especially worth emphasizing in this context: Godard quite expressly addresses the genre of epic and sword-and-sandal films, just as $\grave{A}$ bout de souffle (Breathless, 1960) addresses the gangster film or Les Caribiniers (1963) the war movie. ${ }^{9}$ This is suggested not just by the volume of relevant productions that year, and

9 Jacques Aumont, "The Fall of the Gods: Jean-Luc Godard's Le Mépris," in Susan Hayward and Ginette Vincendeau (eds.), French Film: Texts and Contexts (London and New York, 1990) 218-19. 
not just by the Odysseus theme, which shimmers through in the reflection of the film production within the film and the story of its protagonists, Camille and Paul. There are also countless details such as the Cinecittà studios as a setting, the crass calculations of the producer, Bardot's naked movie-star body, and not least the film's multilinguality, which in its constant mistranslations reads like an ironic commentary on the eclecticism of the genre - or the sometimes Babylonian conditions of production and distribution. The list could go on and on.

However much it might be interpreted as a commentary on the swordand-sandal film, Le Mépris operates, as Jacques Aumont has emphasized, within the aesthetic paradigm of the literary avant-garde of the 1950s and 1960s. Rather "coincidentally," according to Aumont, Godard's film follows the trends set for instance by the Nouveau Roman or the Tel Quel group, to the extent that it reflects formally and politically on its own poetics and seeks to render its aesthetic strategies transparent within itself. This "modernist" approach takes a line of attack all its own, since it adopts a dimension of the Homeric epic especially in its mise-en-scène: a reflexive definition of the epic, which likewise sets the process of narration within the narrated world.

"The cinema," said André Bazin, "substitutes for our look a world which conforms to our desires." Contempt is the story of this world.

These words are spoken by a male voice during the film's opening sequence. Here is an echo of the aforementioned opening dialogue from Ulisse, in which Eurycleia refers to Penelope's gaze as the expression of her longing. And in the subsequent odysseys we actually experience a world tailored to our desires, desires encapsulated in a triangular family structure and the temptations and dangers that derive from it. But instead of producing an additional, coherent diegesis, the mise-en-scène, as it unfolds in the first five minutes, already shows that Le Mépris distances itself from this world in order to narrate it, clearly revealing how it dissects the components and conditions that constitute this world in order to make of its functions the interrogated subject matter of the film. And now this world of desire is narrated, the acousmatic voice says, and this narration unfolds as an emphatically analytical poetics: this construction of perceptible telling and being told is the film.

Shooting from a low angle, the camera shows us an alley between buildings on the Cinecittà studio lot in Rome, which ends at visually at a housing development on a hill. In the wide Cinemascope format, the depth of the shot is only suggested by vanishing lines, which delineate 
the tracks along which a camera dolly slowly moves towards us. While a man's voice reads the credits against the background of Georges Delerue's mournful score, the camera crew accompanies a young woman walking into the foreground. Almost imperceptibly, the camera rises towards its approaching counterpart and the crew disappears from the frame until only the cameraman Raoul Coutard and his camera can be distinguished from the blue of the sky. He turns the camera precisely, rolls down, and the literally Cyclopean Cinemascope lens is staring us in the face.

As Farocki and Silverman assess from the corresponding camera angle, what follows now is the "the reverse shot to the shot," what this camera appears to show us: the image of a bed seen through a red filter; on it is Bardot's naked back with Michel Piccoli lying on it and facing her. ${ }^{10}$ Camille initiates a game in which she asks whether he likes one after another of her body parts, going through the various modes of filmic intentionality in the process. She spells out the ways in which the spectator relates to her: some body parts are evoked in their absence (appearing only in silhouette on the sheets, and others are addressed as mirror images), while we see others concretely on screen. All this is accompanied by the repetitive structures of the music, the gliding camera, and changes of light first to white and then to the blue of a nuit américaine. The spectator is already in the thick of things, oscillating between the filmic complexity on display and simple desire, between the individual components, the colors, the regions of the body, words, and music, on the one hand, and their undivided affective impact on the other. It is actually the naked Bardot, but cited through the open construction, as if in quotation marks.

As in the opening sequence, in what follows, too, Le Mépris takes things apart, assembling paratactically, to borrow Rancière's term. ${ }^{11}$ It sets versions alongside versions, translations alongside translations, Greek against Roman antiquity, blue next to yellow next to red, Poseidon against Athena. The mise-en-scène creates strings of correspondences and reminiscences, which are constantly becoming entangled. The camera moves towards us with its anamorphotic lens, addresses us as desiring subjects, and follows the naked Bardot in Cinemascope, the format of spectacle, which later on in the film Fritz Lang would claim was good only for shooting snakes and funerals. The format responds to the camera, Bardot to the format, the female body to exhibitionism as marketing logic, the muscle-bound male

\footnotetext{
10 Kaja Silverman and Harun Farocki, Speaking About Godard (New York, 1998) 33.

11 E.g. Jacques Rancière, (Gregory Elliott, trans.), The Future of the Image, (London, 2007) 46.
} 
bodies of sword and sandal films, our desire, etc. But Le Mépris does not lose itself in the abyss of endless allusions when it goes through the semiotic "exchangeability" of things. Rather, it adopts a sort of dual strategy, on the one hand displaying things in their symbolic, relational value, and on the other repeatedly emphasizing the state of presumptive "self-sufficient" concretion.

If the film begins with the approaching Cyclopean camera, it initially insists on the monocular vision, the simplicity of the cinematic image, which is associated over the course of the film with the figure of Fritz Lang. As a monocle-wearing director and personification of a glorious cinematic past, he represents the positive side of film, especially clearly in the scene in which his figure teaches us about the Greek belief in reality. Horkheimer and Adorno have similar associations with the Cyclops in Homer's Odyssey: ${ }^{12}$

The singleness of the eye suggests the nose and mouth, more primitive than the symmetry of eyes and ears, without which, and the combining of their dual perceptions, no identification, depth, or objectivity is possible.

Much the same is attributed to the camera; like Polyphemus, its one-eyed vision knows no negation. The nominalism of Odysseus is foreign to it, since its first language is concretion.

Joseph Vogl elaborates on this subject using an incidental scene towards the end of the film: ${ }^{13}$

Fritz Lang strolls past, hesitates, points to Francesca, who is leaning against the flaking red of the wall in a yellow bathrobe, and says, "Lovely yellow color," while he walks on.

Vogl then develops a Deleuzian reading of the situation, which interrupts the film's color code for a moment and marks the interval, since yellow according to Piercian semiotics - is still firstness, pure potency. This means that it is established as a quality of sensation, whose effability and materiality are pending. The scene continues, however, and underlines how the potentiality of "yellow" is actualized. Naturally it is Fritz Lang who makes this comment about the color event, but he is followed by Paul, the scriptwriter. When the latter encounters the translator Francesca, she does what she always does, she exchanges, but not as usual words in one language for another; in this case, she exchanges firstness

\footnotetext{
12 Horkheimer and Adorno, Dialectic of Enlightenment, 50.

13 Joseph Vogl, "Schöne gelbe Farbe, Godard mit Deleuze," in Friedrich Balke and Joseph Vogl (eds.), (Gilles Deleuze. Fluchtlinien der Philosophie) (Munich, 1996) 252.
} 
for the relationship, "yellow" for the emblem of intrigue. For it is a pistol she pulls from the yellow bathrobe, which, according to Francesca, Paul had forgotten on the boat, and hands it to him. This immediately creates a relationship, which becomes part of the texture of the intrigue. A gun and a girl, Godard notoriously said, is all you need for a movie - and naturally the gun alludes to the producer Prokosch, his rival, but it also refers back to Francesca, to whom he had previously made advances. The girl and the gun - they emblematically represent the dramaturgical push and pull that rescues the characters from the underdetermined situations, the "any-space-whatevers," and entangles them with one another. ${ }^{14}$

Far removed from the questions of intrigue, such as why Camille despises Paul, or whether Odysseus had had enough of Penelope, as Paul speculates, a central principle of mise-en-scène appears here in a nutshell. The film begins by laying out its objects separately, but openly, only to join them in fatal constellations in a second step. And yet undetermined intervals repeatedly remain in between them. These potentials are threatened by the decision prototypically represented by the producer Prokosch's constant demand that his interlocutors choose between yes and no. "I wanna hear now, yes or no, if you're gonna rewrite his stuff?" - "Let's have a drink at my home. Yes or no?" We can literally watch pure situations of perception - colors and sounds, but also bodies and words appear and then be sucked into the narration, but only to add another level to the epic. After all, Le Mépris operates not just performatively here but also allegorically to refer to a concept of the epic that encompasses its own conditions. Viewed from this allegorical standpoint, Lang alternates between the imperturbability of the cinematographic apparatus and classic realism. The scriptwriter Paul refers to the afterwardness of writing, just as Camille only stands for Brigitte Bardot herself, who for her part represented the very epitome of erotic production value in those years. Francesca functions as the unreliable medium through whom the various production authorities communicate. But it is ultimately the production, manifested in Prokosch, that exerts the pressure to engage in relationship games. The potential of "yellow" becomes a bathrobe from which a pistol emerges, which transforms the bathrobe into the attractive girl with whom Paul was flirting when Prokosch turned to his wife.

Thus ultimately it also becomes clear that Le Mépris develops a notion of the epic that can only be grasped as an aggregate of the process, con-

14 Gilles Deleuze (Hugh Tomlinson and Barbara Habberjam, trans.), Cinema 1: The Movement Image (Minneapolis, MN, 1986) 208. 
dition, and object of the narrative. It is an epic that knows its intervals and conditions and that also marks the construction of gendered, in this case above all female, bodies. For, as the above-described scene at the beginning of the film illustrates, the mise-en-scène emphasizes that it did not simply find the genders as they were, that they do not come from a previous world that the film merely represents. This exact body, which is displayed from the beginning as the erotic center of the narrated world, points beyond this world - to the production, which forces it into a relationship, into desire or contempt. And this also points to the authority that moved Godard himself to film additional scenes with Bardot, whose market value he immediately converted into reflexive-aesthetic added value..$^{15}$

\section{L'Odissea (1968)}

The television production L'Odissea aired some five years later, at a time when the Italian sword-and-sandal film was already well past its peak. As with Ulisse fifteen years before, the producer was Dino de Laurentiis, and Franco Rossi, whose roots lay in Italian neo-Realism, was hired as the main director. The eight-part television format conscientiously translated the epic quality of the Odyssey into episodes, for which reason the individual parts have little of the architecture of suspense traditional in epic film. Instead, L'Odissea is wholly devoted to a reconstruction of the Homeric epic: it includes all of the perspectives, most of the characters, places, and occurrences, while undertaking some dramaturgical filling in of cracks, embellishing this or that aspect and above all adding a wealth of concrete detail.

It is no accident that the film begins with a prologue at the excavations in Troy, south of the present-day Turkish city of Çanakkale, where it takes its cue from the factual nature of the remains. To the solemn tones of the commentator, the camera pans the desolate landscape and then the massive ruins, observing the paved paths, exploring the roughness of the stones, the cracks, laying out rhythmic perspectives through the deserted ruins. Then the film switches to close-ups of Mycenaean death masks, in the manner of the so-called gold mask of Agamemnon discovered during Schliemann's excavations. The camera eyes them, tracks their faces, shooting them in profile and zooming in, as if this movement could

15 Aumont, "The Fall of the Gods," 218-19. 
compensate for the silence of their expressions. After the credits there follows a horizonless shot of the shore, and a female voice announces herself as Athena on her way to Ithaca; a panning shot, however, captures a mature, bearded man who begins to climb the karstic slope to a settlement on a hill: the divine voice has assumed the guise of Mentis, a male narrator now announces. Then we look into the palace, or more precisely the chamber in which Penelope (Irene Papas) works at the loom, packing the weft with the weaving comb, then walks to the window, closes the curtains, and gazes silently. Massive walls, crude wooden grates, and loosely woven fabrics define the visual space. A short while later, when a top view shows the palace courtyard, the scene is complete, for we see people grinding, combing, and shearing among gnarled trees. The ostentatious textures as well as the constant preparing, washing, or roasting show us how this world is grounded in the activities of everyday life, and is constantly being reproduced through labor. There is nothing here of the gaudy splendor familiar to us from the costumes and sets of genre productions. It was from this agrarian world, the film intimates, that Odysseus went off to war. He repeatedly incorporates this world as a point of reference, since it is against the image of home and hearth that the distance travelled is measured. In this sense, the nature of the surfaces, the shadings, the ornaments, and the fineness of the weave change with the stations of his journey. Despite its closeness to genre film, even the Polyphemus episode directed by Mario Bava remains committed to this poetics: the cave of the Cyclops consists of scattered tree trunks, bits of cheese adhere to beards, the breaking of bones is accompanied by painful cracks, and sharpening the stake that will be used to blind the Cyclops becomes a time-consuming labor.

The art direction, however, deviates from actual archeological meticulousness. The nature of the objects and the wealth of detail are more reminiscent of the forced sensualization of the open-air museum, in which legibility is everything. Thus the blood is too red, the dirt too picturesque, and the knitting and the seams too crude, as if the physicality of this world had to be redeemed on the television screen. But this is not the expression of some "misguided" realism, but the very foundation of this production's epic quality. L'Odissea incorporates the polyphony of memory, narration, and song into its serial format and delivers it by unfolding the various spaces under the premise of accessibility to the senses. The diversity of pictorial textures lives up to the pluralism of the epic, so that we see how each perspective and each voice is situated in an experiential world. For Odysseus and Penelope, as well as for Telemachus, this means that they 
are subject to strictly worldly entanglements. In this sense, it is neither want nor absence that drives them, neither "adventurous" urges nor simple longing. Instead, they find themselves in concrete situations, specific relationships to the world. To that extent, L'Odissea pursues a materialistic poetics, which draws its impetus not from gendered predispositions or preexisting psychic driving forces, but rather from different ways of being-in-the-world. To be sure, L'Odissea, too, treats the standard male acting subject with which Odysseus could be identified in Ulisse, depicting him as relative in a twofold manner. That is, on the one hand it shows him in his particularity, when he seeks for a time to extricate himself from the entanglements of the world and then falls back into dependency. It also means showing the male subject in his perspectivity, counterposing his story with the episodes in which, for example, Penelope claims and defends the oikos as her own life-nexus.

The figures act and endure here according to their specific worlds of experience, and this, which is the aim of the mise-en-scène, is made tangible for the viewer. As a context of agrarian production, a shipwreck on foreign shores, or moments of hospitality, these individual spheres of experience are far more dominant than predispositions of character or gender, psychic driving forces, or divine interventions. It is thus this pluralism that relies on the episodic structure just as it honors the epic polyphony. The (re)construction is dedicated to this respective being-in-the-world, to the extent that it conveys to the viewer the essential ability to exchange experiences, which Walter Benjamin understood as a precondition for storytelling. ${ }^{16}$ The forms of gender derive from the respective logics of these worlds. It is no longer the primacy of the gendered psyche - the impulsive male and the patient and receptive female - that is being staged, but rather the primacy of an experiential world from which gender polarity arises in the first place: what man and woman can be is turned into a film experience, an existentially bound gender situated in the world.

\section{"Include Me Out"}

We have now presented three different concepts of the epic, each of which differs in its own way from the recitation of heroic deeds pursued in the

\footnotetext{
16 Walter Benjamin, "Der Erzähler. Betrachtungen zum Werk Nikolai Lesskows," in Benjamin, Gesammelte Schriften, II, 2. (Frankfurt am Main: Suhrkamp, 1977) 438-65; English: "The Storyteller: Reflections on the Works of Nikolai Leskov," in Benjamin (Harry Zohn, trans.), Illuminations (New York: Schocken Books, 1969) 83-109.
} 
genre of the sword-and-sandal film. In Ulisse we saw classic psycho-realism, in which subject and world refer to one another seamlessly, whereby this relationship is marked by gender, by the adventurous male heart on the one hand, and the yearning of Penelope on the other. Le Mépris, in contrast, integrates the boundaries of its own narrative into its concept of the epic. The mise-en-scène repeatedly seeks to overtake an exterior world, whether by suturing the camera into the diegesis, imagining a world before its narration, or by the function of the production, personified by Prokosch as the center of gravity of the whole complex of actions. In intervals, indeterminate perceptions and unpositioned subjectivities are realized, become linked, and identified relationally.

In this way, the film places quotation marks around the characters, the genders, and the relationships they enter into. The final example, L'Odissea, in contrast, highlights the experienceability of divergent contexts, thereby interweaving the parcours of the story with the epic discours. It suggests a notion of the epic that relates the respective alienness of the journey's destinations to the perspectivity of the narrative process, thereby ascribing an irreducible pluralism to both. These experiential spaces, which L'Odissea creates over its eight episodes, lend sensory form to this pluralism, while certifying for the figures, genders, and relationships - (by showing them) the degree to which their potentials are measured by the experiential worlds, i.e., their identities are constituted by pacing off these realms of experience.

These three strongly filmic means of developing a concept of the epic also develop corresponding concepts of the subject, which cannot be separated from gender: preformed as gender binarism, referred reflexively to the conditions of production, or situated realistically. There is also some indication that the question of the mismatch between genre film and Odysseus points to the construction of the epic, which the Homeric figure of Odysseus challenges, and thus extends beyond the superficial contrast with the hyperbolic masculinity of the protagonists of genre film.

In Le Mépris, Fritz Lang refuses his producer's invitation by saying "Include me out." As we have seen, "include me out" applies not just to the Cyclopean realistic camera, which of necessity does not belong to the depicted world, and not just to the Homeric Odysseus and his capacity for self-denial or his absence from home; it also refers to the mutual incompatibility of Odysseus and the Italian sword-and-sandal film.

Should we attribute this to the nature of the figure or, to be more precise, to the cunning that the Dialectic of Enlightenment elucidates as the ambivalent history of the emancipation of the modern subject? Was the genre film incapable of bearing the self-denial of its main character? This 
may be the case, but the reference to an isolated character trait appears rather weak. If we turn once again to the Homeric epic, a further aspect presents itself. For we must take into account that the figure of Odysseus represents a particular interpretation in the work of Horkheimer and Adorno, just as do the reflections we have made on the margins of the genre. Their history of the Enlightenment focuses more on the protagonist's cunning qualities, his capacity for instrumental negation, and less on his second well-known epithet: Homer's epic also refers to him as Odysseus the much-enduring. Horkheimer and Adorno address this endurance only as forbearance, the painful passing of the tests set him. In Homer's epic, however, endurance insists on the value it has in its own right, since it is the mirror image of cunning - the instrumental self-reference that gains us the world - of the melancholy self-reference that transforms the world into an image of its loss. Successful self-mastery through self-denial correlates structurally with the experience of powerlessness, for in both instances the individual retreats from the world, extricating him/herself from immediate entanglements.

Against the backdrop of a subject who experiences power and powerlessness equally, the mismatch between the genre and the figure of Odysseus appears more serious than it seemed at first. For the Italian sword-and-sandal genre, it is not just the melancholy of its male protagonist, or, more generally, the ambivalence of the experiencing subject, that constitutes the scandal; the actual problem is the challenge that the epic quality of Homer's Odyssey represents, since it refers fundamentally to a concept of the subject derived from the interval between impulse and response. It is only in this intermediate space that a ruse can be considered, just as it can be filled with the experience of loss, mourning, and dependency. What appears problematic here are not the values of the potential contents of experience, since the indeterminate openness of the subject proves to be an elementary precondition of narrative reflection. Constituted in this manner, the experiencing subject is capable of articulating itself through storytelling, by placing itself in relation to the various experiences and processing the contradiction between instrumental and pathetic self-reference through narrative. According to Horkheimer and Adorno, this contains an element of emancipation, since it is a matter of "the self-reflection which causes violence to pause at the moment of narrating...."17

17 Horkheimer and Adorno, Dialectic of Enlightenment, 61. 
In this sense, Homer's Odysseus insistently poses the question of the relationship between accessing the world and losing it, how these processes are distributed, and how they are expressed. This produces the sharpest contrast to the genre of the sword-and-sandal film, above all to the imagination of self-identical male agency, which in its filmic form promises a seamless succession of altered world conditions. Perhaps for that reason, the melancholy of the Odyssey is its most radical, and certainly its most instructive, element, since, more strongly than the cunning that still operates indirectly on the world, it generates the freedom of narrative expression. A general reference to the constant stream of tears, laments, longing, pain, and mourning in Homer's epic poem must suffice at this point.

\section{Conclusions}

Ulisse expresses the relationship between deceit and forbearance in the tension between the sexes, bringing it into a binary order. The worldexploring element lies with the male side of the couple, while the loss is borne almost exclusively by Penelope. Le Mépris, in contrast, resists a predefined order, revealing in the process how couples, genders, and intrigues can be cited and yet remain indeterminate until they inevitably fail under the driving power of "yes or no." Godard's film externalizes the pattern of action and suffering to such an extent that the defining and acting moment ultimately always points outward, to the production process and its market exploitation. In L'Odissea, in turn, each gender role is explored in its specific existential basis and narrativized pluralistically. The television production reconstructs the subject as a site of experience, not simply by representing it as a figure, but also by reflecting it in television viewers, especially since the alienness and density of different experiential worlds are perspectivized with them in mind.

Each notion of the epic always also contains the gendered division of experience, but if we place the three poetics alongside one another, it becomes visible as a filmic construction and not simply a representation of roles. Only the concrete film experience, which becomes comprehensible only through the analysis of the mise-en-scène, conveys the concept of the epic realized in a specific instance as the self-created relationship between what is seen, felt, and understood. In epic poetry, in contrast to genre film, the quality of the epic speaks of the fundamental necessity of the experience of powerlessness for the male subject as well. 


\author{
"Include me out" means freeing the subject from the immediate con- \\ texts of violence.
}

\title{
Works Cited
}

Aumont, Jacques. "The Fall of the Gods: Jean-Luc Godard's Le Mépris," in Susan Hayward and Ginette Vincendeau, eds., French Film: Texts and Contexts (London and New York: Routledge, 1990).

Benjamin, Walter. "Der Erzähler. Betrachtungen zum Werk Nikolai Lesskows," in Benjamin, Gesammelte Schriften, II, 2. (Frankfurt am Main: Suhrkamp, 1977) 438-65; English: "The Storyteller: Reflections on the Works of Nikolai Leskov," in Benjamin, Illuminations (trans. Harry Zohn; New York: Schocken Books, 1969) 83-109.

Birkenhauer, Theresia. "Episches Erzählen - ein Erfahrungsraum," program for Isabel Mundry, Ein Atemzug. die Odyssee, Deutsche Oper Berlin, 2005/2006 Season.

Blumenberg, Hans. Die Lesbarkeit der Welt (Frankfurt am Main: Suhrkamp, 1981).

Deleuze, Gilles. Cinema 1: The Movement Image (trans. Hugh Tomlinson and Barbara Habberjam; Minneapolis MN: University of Minnesota Press, 1986).

Dyer, Richard. White: Essays on Race and Culture (London: Routledge, 1997).

Horkheimer, Max and Theodor Wiesengrund Adorno. Dialektik der Aufklärung: philosophische Fragmente (Frankfurt am Main: Fischer, 1998). English: The Dialectic of Enlightenment: Philosophical Fragments (trans. Gunzelin Schmid Noerr; Stanford CA: Stanford University Press, 2002).

Rancière, Jacques. The Future of the Image (London: Verso, 2007).

Silverman, Kaja and Harun Farocki. Speaking About Godard. (New York: New York University Press, 1998).

Sorlin, Pierre. "Die Genrefilme der 196oer Jahre. Kolossalfilm und Western," in Thomas Koebner and Irmbert Schenk, eds., Das goldene Zeitalter des italienischen Films: $1960^{\text {er }}$ Jahre. (Munich: Ed. Text + Kritik, 2008).

Vogl, Joseph. "Schöne gelbe Farbe, Godard mit Deleuze," in Friedrich Balke and Joseph Vogl, eds., Gilles Deleuze - Fluchtlinien der Philosophie, (Munich: Fink, 1996). 



\title{
BETWEEN MYTHICAL AND RATIONAL WORLDS: MEDEA BY PIER PAOLO PASOLINI ${ }^{1}$
}

\author{
Lada Stevanović
}

The subject of this chapter is Pier Paolo Pasolini's film adaptation of one of the most shocking and intriguing plays from Greek antiquity, Euripides' Medea. This is a text that continues to inspire generations of artists - mostly playwrights, but also writers and film directors - who approach it in many different ways, dealing with the issues of an oppressed foreign woman, who, in the Euripidean account, brutally killed her children. ${ }^{2}$ Copious research in the reception of ancient tragedies has shown that adaptations of dramas, interpretations, and translations have always depended on particular contexts in which recognized social and political needs of the moment were addressed according to cultural variations, sensitivity of the artist, personal style, creativeness, and affinities. Before I turn my attention to Pasolini's Medea, however, I will offer my interpretation of the essence of the Euripidean play that Pasolini adopted in its original context - ancient Athens, where it was written and produced late in the fifth century BC. After doing so, I will offer my interpretation of Pasolini's film, especially as regards his attitude toward and relation to Euripides' text, and regarding certain specificities that he developed as a consequence of a new context the 1960 - in a dimension we might say intersected with Pasolini's reading of Euripides' drama and this ancient tragedy.

I turn first to Euripides' drama in the ancient context in which it appeared and discuss briefly the meaning of theater in Athenian public life. Ancient tragedy explored mechanisms that lead to the destruction of the individual, dealing with all the contradictious powers that can influence any culture and any individual in the conflicted society. ${ }^{3}$ As one of the institutions of Athenian democracy, the theater was also a venue in

1 This paper was commenced during the postdoctoral research project "Ancient Drama in Contemporary Theater, Cinema and Literature" at the Institute for Advanced Studies, University of Edinburgh and finished in Belgrade in the project "Cultural Heritage and Identity" No. 177026, financed by the Serbian Ministry of Science.

2 This drama has a rich history of adaptations that has been (as much as it is possible) reviewed, analyzed, and presented in Edith Hall, Fiona Macintosh, and Oliver Taplin, eds., Medea in Performance 1500-200o (2nd ed.; Oxford: Oxford University Press, 2000).

${ }^{3}$ Jean-Pierre Vernant and Pierre Vidal-Naquet, Mit i tragedija u antičkoj Grčkoj (Beograd: n.p., 1995) 103-104. 
which audiences were forced to confront many questions, especially those that were too complicated or sensitive to be raised in the assembly and discussed in the general public. ${ }^{4}$ This institutionalized "control" aspect of the assembly opened a space for subversiveness, which Froma Zeitlin identifies as female because it confronted the community with the domain that was considered to be feminine, and in a way that was feminine. That is, although the theater was a homosocial institution, it functioned in the feminine way through the transgressions and the display of the (male) actor's body, through the confrontation with pain and loss, and through the multiplication of identities. In that way theater was the arena for challenging the dominant ideas and concepts of identity. ${ }^{5}$ The subversiveness of the Athenian theater in general and of Euripides' Medea in particular is precisely one of the most important links and issues that I would like to address in discussing Pasolini's film.

That the main character of Euripides' play and of Pasolini's film is a mother who kills her children leaves no doubt that this drama is dealing with the issue of power and the problem of the Other. This is demonstrated through Medea's status as a woman and a foreigner, which has been the aspect of this drama most frequently identified and exploited in adaptations. ${ }^{6}$ A very important aspect of the representation of Medea's womanhood is that she, though a barbarian, is at the same time represented as a Greek mother and wife. ${ }^{7}$ The radical act of Medea's infanticide may be understood as the only way in which she could overcome the

4 Nicole Loraux, The Mourning Voice, An Essay on Greek Tragedy (Ithaca NY: Cornell University Press, 2002) 15: "But theater, tragic theater at least, was also - and perhaps best equipped to deal with issues that the citizens of Athens preferred to reject or ignore."

5 Froma Zeitlin, Playing the Other (Chicago: The University of Chicago Press, 1996) $362-364$.

6 Edith Hall stresses the point that one of the important issues that Greek tragedy (in particular Medea and Heracles) problematises, and that is so little recognized in today's world, is the problem of children's rights. Until today, only one of the adaptations has addressed this, Peter Sellars's The Children of Herakles. In order to emphasize the political dimension of the play, the director invited "real-life" children, Kurdish asylum-seekers, to sit on the stage silently throughout the pla; in Ondine Corinne Pache, ed., Baby and Child Heroes in Ancient Greece (Urbana IL: University of Illinois Press, 2004) 9. Another unresearched domain that the Medea myth opens is the problem recognized by Pache, who argues that this myth (regardless of version) embodies a mythical representation of parents' darkest fear - direct and indirect responsibility for their children's life and, even more important, death. This conclusion is the result of the systematic and profound research on myths (and the Medea myth is one of these) and cult practice in honor of dead children.

7 According to William Allan, Euripides: Medea (London: Duckworth, 2002) 67, this very contradictious representation (of barbarian and of Greek as barbarian) is one of Euripides' ways to confront his audience with prevailing stereotypes about barbarians and to call them into question. 
situation in which she found herself. With the act of killing her own children, Medea - as a woman and as a wife - confronted the power of her husband and - as a foreigner - the power of the king. Medea's attack on her children and Jason's future bride Glauce, King Creon's daughter, was an act in which she utilized the only advantage that a woman had over men - the ability to give birth. ${ }^{8}$ However, the main contradiction around which the plot of the tragedy is actually woven is that Medea's only advantage is simultaneously her greatest disadvantage. I am thinking here about the reduction of Medea to a mother function, one who has already fulfilled her destined role and become useless and despised. It is this which impels her to reject the prescribed role and to reestablish herself in relation to Jason and the dominant society in the only way that was available to her. The shocking and horrible act of infanticide was so painful and harmful for Medea that nobody expected that she would ever do it. However, she reacted in the only way in which she could reestablish herself socially - in the only way in which she could become a real oppositional force, noticed and heard, which was otherwise impossible. ${ }^{9}$

In my view, therefore, Euripides' choice to radicalize the myth (since in most of the earlier versions, it is not Medea but the Corinthians who kill Medea's children in order to punish her) and make it even more shocking was aimed at disturbing the Athenian audience and confronting them with these problems - the issue of power and the problem of the Other. Although there are scholars who argue that Euripides' Medea is driven only by passionate and irrational motivations, we should not forget that in line 1079 Medea emphasizes that her ultimate devotion to her principles does not mean that she is irrational. ${ }^{10}$

And I know well what pain I am about to undergo, but my wrath (thumos) overbears my calculation (boulematôn).

8 Even Jason in Euripides' play (573-575) complains about men's dependence on women regarding childbirth. "Mortals ought, you know, to beget children from some other source, and there should be no female sex."

9 In the text of Ruth Hazel's "Electra: A Fragmented Woman," in L. Hardwick, ed., Theatre Ancient and Modern (Milton Keynes: Open University, 2000) 82-90, Hazel points to the deconstruction of numerous female characters in Greek dramas (Electra, Hecuba, Medea, Antigone, Jocasta), who, "stripped of the social roles which had previously defined them (queen, wife, mother, daughter), are de-constructed as social entities and reduced to their essentials: their psychological make-up and their physical attributes of age and gender."

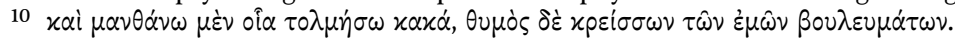


Or, to put it in words of Rush Rehm:11

When Medea is saying that her thumos is stronger than her boulematôn, she does not mean that her passion is stronger than her reason, but that her commitment to her principles [namely to take vengeance on enemies and avoid their mockery] is stronger than any competing claims." ${ }^{2}$

According to Froma Zeitlin, Medea actually adopts the male, heroic mode of behavior, claiming that she would rather fight in a battle than give birth again, and identifies therefore with men as her model and anti-model destroyer. Medea is courageous, energetic, and loyal, and as any other hero, she chooses to act, and to kill, unlike the many other women in tragedies who decide to commit suicide, traditionally a woman's way of confronting problems. In the view of Nicole Loraux, it is often that women die in tragedy by their own hand because, doomed to fateful circumstances with no choice or option to behave actively and independently, their only opportunity for confrontation and rebellion takes place in their nuptial bed, identified by Loraux as a woman's battlefield. ${ }^{13}$ Although Medea longs for her own death: (227)

I am undone, I have resigned all joy in life, and I want to die -

she decides to perform a more radical act. She is one of the rare women who accepts this heroic model, who dares to be angry at her oppressors and seek vengeance.

Pasolini problematized as well the issue of the social unacceptability of women's aggression and active confrontation with those who have power

11 Rush Rehm, Marriage to Death: The Conflation of Wedding and Funeral Rituals in Greek Tragedy (Princeton: Princeton University Press, 1996) 147. This verse is part of one of the most frequently discussed and variously understood verses in Medea's monologue $\left(105^{6-80}\right)$. It is not rare for scholars investigating the play to focus on this monologue and particularly verses 1078-1080, interpreting them as revealing Medea's inner conflict between reason and passion. Helene P. Foley, "Tragic Wives: Medea's Divided Self," in Female Acts in Greek Tragedy (Princeton: Princeton University Press, 2001) 244-248, warns about the danger of taking an anachronistic approach to this issue and imposing modern ideas on this passage, emphasizing that it was precisely a simplified reading of Medea's conflict as a struggle between reason and passion that would lead to understanding the drama as merely a story about passion and jealousy.

12 This nuance points to Euripides' awareness of women's position and related stereotypes, especially when we keep in mind that the dominant discourse in antiquity aligned men with reason and women with emotion. For the ancient trope that the open display of emotions was considered as "effeminate," see, for example, Plato, Laws, 732c, Republic 387b-d; and 6o6c. For Euripides' awareness of women's subordinate position, see Allan, Euripides: Medea, 230-252.

13 Nicole Loraux, Tragic Ways of Killing a Woman (Cambridge, MA: Harvard University Press, 1987). 
in the double enactment of Glauce's death. In the first enactment, which Medea imagines, Glauce dies shortly after she puts on her new dress - a wedding present from Medeas - and it bursts into flames. In the second, which is the "real" enactment, Glauce receives the present and then leaps from the castle walls. So now she commits suicide, as if wearing this dress were for Glauce the same as being "in Medea's shoes." The argument in favor of such an interpretation is that even Creon, when talking to Medea about her exile, says that his main reason for forcing her into exile is that he is worried for his daughter, who sympathises with Medea. Creon may claim that these worries are his only motivation for Medea's exile, but he ultimately confirms that his reasons for banishing Medea lie in his disdain of her barbaric origins. At the end of the Euripidean exchange between Medea and Creon (270-356), Pasolini (who wrote and directed the film) appends the following lines:

In truth, I am not banishing you because of hate..., or suspicion, because you are different, a barbarian, who came here with the markings of another race upon you..., but rather out of love for my daughter, who feels remorse for you. She knows what you are suffering, and she suffers too.

Although he claims the contrary, Creon's statement actually confirms his racist position. He makes the type of discriminatory statement which usually begins with a denial of being a chauvinist, nationalist, or racist, after which follows the discriminative argumentation for rejecting the Other, which, according to the speaker, derives from the real facts. Although he uses only one such statement, Pasolini raises a question that would be of great importance in any chauvinist discourse.

Another significant aspect of the film is the mythical one. But before examining Pasolini's approach to myth, I will turn once more to Euripides' drama. It is precisely because the issue of myth is so important and operative in Pasolini's version that I need to address briefly Euripides' plot and the plots of ancient tragedies in general. These plots were usually mythical stories or events from the distant past. In the words of Nicole Loraux: ${ }^{14}$

Tragedy represents the grief of the Other, not the Self. The Other must be distanced from the Self, whether in time (hence the appropriateness of myth in general) or in space (hence of the appropriateness of Persia in Aeschylus's Persians).

14 Nicole Loraux, Mothers in Mourning (Ithaca NY: Cornell University Press, 1998) xi. 
One of the most important reasons for this can be traced to the Athenian city-state's ban on adapting recent events for tragic plots. The Athenians introduced a law aimed at controlling the plots of tragedies and their emotional impact after the 493 BC performance of Phrynichus's drama The Capture of Miletus. The plot of this play was related to the tragic Persian siege of Miletus. The Athenians felt such sympathy for the Ionians who experienced this horrible event and suffered such turmoil themselves that they enacted this ban..$^{15}$ Although it did not seem so at first, the ban on this particular play influenced the whole tragic genre. ${ }^{16}$ From that time on, plots could be based only on the mythical stories or something that happened long before.

In addition, Athenian playrights employed and created many different variants of Greek myths in their dramas, which was an important factor in making them so suitable for problematizing different issues. By reusing old myths with which the audience was familiar but then adapting them to address a variety of issues, they did not have to focus on the original story so much as the way in which they wanted to retell and reshape it.

Pasolini had innovative reasons for devising a mythical theme for his Medea. This film belongs to a period in the 1960 s during which Pasolini wrote and directed a group of films with mythic themes closely related to not the ancient canon but his extreme leftist ideas - the rejection of modern Western society and the critique of power in the Foucauldian sense. ${ }^{17}$ The mythical world that Pasolini devised for Medea, her relationship with gods and nature, is a world that he sets in opposition to the modern rational world of linear historical progress. We can interpret this through Julia Kristeva's notion of masculine and feminine time. That is, the masculine time is linear and oriented towards progress - Jason belongs to this time - while the woman's time is cyclical and repetitive but also monumental, and does not fit into the aforementioned historical time-

15 Herodotus, Histories, 6.21.

16 Loraux, Mothers in Mourning, 85-86.

17 In his November 1, 1975 interview with Furio Colombo, his last [We are all in danger, online at http://www.leftcurve.org/LC3oWebPages/Pasolini's\%2oLast\%2oInterview.html], Pasolini said: "Power is an educational system that divides us into subjects and subjected. Nevertheless, it is an educational system that forms us all, from the so-called ruling class all the way down to the poorest of us. That's why everyone wants the same things and everyone acts in the same way. If I have access to an administrative council or a Stock Market manoeuvre, that's what I use. Otherwise I use a crowbar. And when I use a crowbar, I'll use whatever means to get what I want. Why do I want it? Because I've been told that it is a virtue to have it. I am merely exercising my virtue-rights. I am a murderer but I am a good person." 
frame. ${ }^{18}$ According to Kristeva, the beginning of the feminist movement can be characterized by the fight of suffragettes and existential feminists for gaining the right to vote, which aimed at bringing women into and including them within the projects of history, and, as Kristeva defines it, into the linear time progression. On the other hand, Kristeva claims that during the second phase, after 1968, feminists rejected linear time and turned to the searching of those aspects of women's identity (intrasubjective and corporeal experiences) that cannot be reduced to and identified with those of men. This identity is multiplied and so impossible to define, and it is related with the archaic and mythical memory. The third phase is a combination of these two as an effort to insert women into history while rejecting the limitations of the historical time and its subjectivity. This phase shortly precedes the time when Kristeva wrote this article in the 1980s. ${ }^{19}$ Pasolini's film reflects the feminist attitude of the time when he filmed Medea in 1969, criticizing and rejecting linear historical time and progress, and showing in his film that the acceptance of this dominant historical model and an effort of the Other to be included in it, may have disastrous consequences. ${ }^{20}$ In one interview Pasolini himself confirmed this with the following words: ${ }^{21}$

I don't believe in this history and this progress... what is required is total criticism, desperate and useless denunciation.

In this sense Pasolini creates in Medea a product of the clash between non-historical/non-progressive and historical time. He recognizes the repression and unrecognized status of the domain/time to which Medea originally belongs, especially when it is merged into and swallowed by the dominant masculine one. However, Medea's rebellious reaction also belongs, as I have already stated, to the domain of rational entrance into historical linearity, because it was her only option to be noticed and respected. It is therefore possible to claim that Pasolini's political orientation, standing up for the non-European, postcolonial Other and all those

18 Julia Kristeva, "Women's Time," in Toril Moi, ed., The Kristeva Reader (New York: Columbia University Press, 1986) 191-193.

19 Kristeva, "Women's Time," 193-195.

20 As I have already said, Medea actually adopts the male, heroic way of behavior. Medea was initially released in Italy in December, 1969.

21 Pier Paolo Pasolini, 1976 Lettere Luterane, Torino, Einaudi Editore, 115 from Ana Grgić, Salo o le 120 giornate di sodoma, 10, accessed November 29, 2011, http://www.scribd .com/doc/14430537/Pier-Paolo-Pasolini-Salo-or-120-Days-of-Sodom. 
people who are socially endangered in the twentieth century, ${ }^{22}$ served as his reason for choosing a myth about the infanticidal mother Medea, revealing that repression and lack of space in which the Other can react or speak may lead to a very radical reaction and catastrophic events after which "nothing is possible anymore," as Medea says at the end of the film. ${ }^{23}$ Such powerful artistry and expression in Medea Ian Christie describes as an "act of artistic terrorism."24

Although Pasolini did not alter the main line of the plot, he did not adhere firmly to Euripides' text. Pasolini himself is on record stating that themes that appear in his Medea are the same that can be found in his other films, while Euripides' play was only a source of some quotations. ${ }^{25}$ From the very beginning of the film, the first half of his narrative does not belong at all to Euripides drama. He uses this footage to capture images of Colchis, the arrival of the Argonauts, the taking of the fleece, the encounter with Pelias and his daughters, and so on. However, in my view, despite these numerous variances and still subsequent inconsistencies in regard to Euripides' text (as we saw with the appendix to Creon's speech discussed above), Euripides' drama is not reduced in scope. Pasolini used such other film tools as picture, tone, costume, text, silence, frame, and montage to express everything that exists in Euripides' Medea, and, most importantly, to focus on the issues of power, political subversivness, and the reaction of the oppressed. For example, his eclectic use of costumes, music, and ambience corresponds to the dominant problem of the film - exclusion of the Other, and Pasolini playfully includes and mixes elements of different cultures, challenging the dominant ideas that devaluate eclecticism and thereby questioning the concepts of nation and national cultures that are

22 Pasolini especially refers to contact of Africa with Western civilization and to the poor working class of Italy. See more in Kenneth MacKinnon, Greek Tragedy into Film (Rutherford NJ: Fairleigh Dickinson University Press, 1986) 148. He also says "There is a key idea held in common by everyone, sincerely or not: the idea that the worst evil in the world is poverty and that therefore the culture of the poorest classes must be replaced with the culture of the dominant class. In other words, our guilt as fathers is constituted by this fact: believing that history is nothing other and can be nothing other than bourgeois history." Cf. Sam Rohdie, The Passion of Pier Paolo Pasolini (Blooomington IN: Indiana University Press, 1995) 168.

23 An irrefutable fact of which Pasolini must have been aware is that the time of rationality and progress opened a space for women and other oppressed groups to start conquering space to speak and react.

24 Ian Christie, "Between Magic and Realism: Medea on Film," in Edith Hall, Fiona Macithosh, and Oliver Taplin, eds., Medea in Performance 1500-200o (Oxford: Oxford University Press, 2001) 154-155. Two other examples are the films Pigsty and Salò o le 120 giornate di Sodoma.

25 Jean Duflot, Entretiens avec Pier Paolo Pasolini (Paris: Pierre Belfond, 1970) 111. 
always dependent upon the process of homogenization that stigmatizes the Other. ${ }^{26}$

Medea begins with the scene of mythical past that precedes Euripides' drama: on his fifth birthday Jason is with the (unnamed) Centaur who, according to the myth, brought him up. The naked boy, riding on the back of the equine portion of the centaur, is listening to the story of the Golden Fleece. His four-footed teacher talks to him about nature and tells him that everything that he sees is just a phantasm, that god is hidden everywhere, and that everything is sacred - but that "holiness is also a curse." This should be understood in the light of the ancient meaning of "sacred," that is, pertaininig to any religious understanding of cosmic totality, as opposed to the rationalistic worldview. That is, if we analyse some Greek and Latin roots and terms that denote "sacred" and "holy" (Greek $\pi \alpha v a \gamma l$, a $\gamma 10$ - and Latin sacer), which at the same time denoted "accursed" and "execrable," we may understand that these two concepts and two aspects of the same sacred reality are actually impossible to separate. ${ }^{27}$ So, what is also necessary to understand regarding the traditional religious worldviews is that gods, belief systems, cults, and the sacred in general are rarely related to something that is exclusively "good" or exclusively "bad," or, as the centaur says in the film:

The gods that love can also hate.

This is similar to the concept of taboo that always concerns danger (especially when not treated according to the religious rules), which at the same time contains strength, potential protection, and power. ${ }^{28}$

This episode and the centaur's explanation of the sacred might also reflect Pasolini's attitude towards religion. Although he claimed that he was an atheist, answering a question at a 1966 press conference about his atheism and dealing with religious themes, he answered:29

26 MacKinnon, Greek Tragedy into Film, 147-148, reports that the costumes represent a mixture of Andalusian and Mexican motives, and that the music and instruments are Japanese, Arabic, Bulgarian, and Tibetan, while the film was shot in Cappadocia, Syria (Aleppo), but also "a large fortress in Pisa." The fortress is in Aleppo. Explaining the eclecticism of another film, Oedipus Rex, Pasolini himself said that his intention was to represent the myth as a dream, and that the only way was that of aestheticization. Cf. MacKinnon, 144.

27 Veselin Čajkanović, Studije iz srpske religije i folklora (Beograd: SKZ BIGZ, 1994) 2, 250.

28 Much influence on his work made ethnological research and anthropological theory especially works by Mircea Eliade, Lévi Bruhl, and James George Frazer. Cf. Duflot, Entretiens avec Pier Paolo Pasolini, 111.

29 http://users.hal-pc.org/ questers/pasolini.html. 
If you know that I'm an unbeliever, than you know me better than I do myself. I may be an unbeliever, but I am an unbeliever who has a nostalgia for a belief.

In another interview he said:30

I suffer from the nostalgia of a peasant-type religion, and that is why I am on the side of the servant... But I do not believe in a metaphysical god. I am religious because I have a natural identification between reality and God. Reality is divine. That is why my films are never naturalistic. The motivation that unites all of my films is to give back to reality its original sacred significance.

Sacredness for Pasolini lies in reality, which for him is divine, and this should be understood as the rejection of any mystification on the account of respect towards reality and life, or towards bare life as it is defined by Giorgio Agamben. Pasolini rejects Christianity, he rejects the institution of the religion, and in the same way he rejects the political institutions pointing to the delicate and fragile spot in modern democracies, which claim that life has the highest value, at the same time endangering it. ${ }^{31}$

Let me turn now to the third segment of the initial centaur episode, in which the centaur now addresses the adult Jason, saying:

In the ancient world myths and rituals are living reality. Part of man's everyday life. For him reality is such a perfect entity that the emotion he experiences at the sight of a tranquil sky... equals the most profound professional experience of modern man.

After that centaur predicts the future for Jason, telling him that he will go to Colchis to take power from his uncle, and that he will find there a world different from the one he knows. In this world mythical beings are real, real beings are mythical, and life is real as well. The centaur also tells Jason that through the act of cultivating land people discovered the most important truth, and that is the "final lesson - The Resurrection." In addition, he foretells that Jason will make many mistakes and that everything that will happen to him will be related and determined by divine will. Already this introductory scene contains the core of the problem that reverberates throughout the film, and that is the conflict between two worlds: one mythical and religious, the other real, political, and rational. The paradox

30 Guy Flatley, “One Man's God, Another Man's Devil,” The New York Times (April 20, 1969) D15; cf. http://www.moviecrazed.com/outpast/pasolini.html.

31 Giorgio Agamben, Homo Sacer, Sovereign Power and Bare Life (trans. Daniel HellerRoazen; Stanford, CA: Stanford University Press, 1998) 13: "Today politics knows no value (and consequently no nonvalue) other than life, and until the contradictions that this fact implies are dissolved, Nazism and fascism - which transformed the decision on bare life into the supreme political principle will remain stubbornly with us." 
is, of course, that Jason belongs to both of these worlds. All the same, although Medea originates in the religious and mythical domain, with no other outlet for her to react and confront Jason, she transgresses into the world of reality, politics, and rational confrontation.

The film immediately moves to the setting in Colchis, beginning with the scene that deals with the secret of life, the one that was mentioned by the centaur: the cyclic nature of life. A fertility ritual is performed, and a young man, with a smile on his face, is sacrificed to gods. Pasolini pays a great amount of attention to the details, including the smile of the victim in the ritual sacrifice that symbolizes consent, a necessary component for the successful ritual. The sacrifice episode concludes with the sequence in which Medea, who as a priestess that turns the wheel (a symbol of life-cycle), says:

Give life to the seed and be reborn with the seed.

On her way to Greece, Medea is utterly horrified at the disrespect the Argonauts display towards the gods, and through the rest of the film (except for the love scene between Medea and Jason in Corinth), the clash between Medea's world of the sacred and religiousness and Jason's world of reality and rationality will dominate. The tension between these two worlds is visually represented in the scene with two centaurs. One of them is the one who nurtured and educated Jason, and he belongs to the world of the irrational and sacred. The other belongs to the rational world.

There is no doubt that two centaurs appear because Jason's destiny is interlaced with both worlds. But another possible interpretation of the presence of the two centaurs might posit that the first centaur personifies Greek pagan tradition and the religious principles of Greek Others (women, barbarians, children) according to which the majority of the people in ancient Greece lived, while the other represents the Platonic tradition of rationality that corresponds to the dominant and elite ideas of Greek identity. In spite of the great esteem in which rationality was held by Plato and his followers in particular, it is impossible to claim that this was the single or the prevailing principle in antiquity. However, the European elite, especially that of the nineteenth century, decided to disregard the traditional ancient Greek religious belief system and favored instead the tradition of Platonism as the only relevant system, comparing it to their own Christian values. ${ }^{32}$ Pasolini's awareness of this problem

32 Wole Soyinka, Myth, Literature and the African World (Cambridge: Cambridge University Press, 1990) 3: "This gradual erosion of Earth in European metaphysic scope is probably due to the growth and influence of the Platonic-Christian tradition." 
actually represents his criticism of colonization, this time the European colonization of the ancient Greek past, in which Europe was inclined to cherish and emphasize exactly and only those values that corresponded to its own ideology. In these terms it is possible to claim that Pasolini's film corresponds with the studies of antiquity of his period, because it was precisely during the 1960 s that representatives of the French anthropological school of antiquity began to study the colonization and idealization of the ancient past.

After ten years, Jason has fallen out of love with Medea. In their palace, Medea finds out from her nurse that the people of Corinth are afraid of her. Struggling in her helplessness, with the support of the chorus of women, Medea realizes that she is the same as she used to be, "a vessel for a wisdom that comes from outside myself." This means that she belongs completely to the gods, and this corresponds to Greek ideas about prophets and poets, who did not consider themselves responsible for what they spoke or created. The gods and muses worked through them in order to establish a satisfactory level of divine balance and justice. Pasolini visualizes the divine support Medea is given by her grandfather, the sun-god Helios, to kill her sons and Glauce by framing the sun and then showing Medea looking towards the sky.

Medea also asks for the help and support of her nurse, who questions Medea about the pain that she will impose on herself. In the dialogue in which Pasolini paraphrases Euripides, Medea's ultimate response to the nurse is that she, being a woman, should understand her.

Nurse: Now that you have told us of your intentions, we want to be of help to you, but at the same time, respectful of the most sacred human laws.

Medea: It's too late to take any other course. You cannot assent to what I am about to do, because you have not suffered the wrongs I have!

Nurse: How will you find the courage to do what you plan?

Medea: I will find the courage when I think how great will be his suffering. Nurse: But yours will be no less, poor desperate woman that you are!

Medea: That's enough, Nurse! It is time to act.... You love me, and you are a woman.

This puts Medea's problem into a wider context and questions the position of any Greek woman. By doing so, Pasolini indirectly suggests that Medea's religious belief in the world beyond belongs not only to irrational barbarians but also any (Greek) woman.

The scene in which Medea prepares to kill her sons resembles a religious sacrifice with the ritual washing of the victim that often precedes it and the climax of fire. Medea bathes the boys in a stone tub-altar that 
has the symbolic shape of a circle, as does the room in which the tub is placed. Pasolini does not show us the act of killing, and he replaces Helios' chariots that in Euripides' version come to take Medea and boys away with the final scene that takes place outdoors in the sunlight.

Pasolini created a contemporary adaptation of Euripides' drama on film. Although he did not follow Euripides' text literally and omitted much of the dialogue, his film does not reduce Euripides' tragedy. Pasolini created myth on film and by visualizing a mythical language adapted for the contemporary spectator to replace the perspective of the ancient spectator. To achieve this effect, for example, he replaced Helios' chariots flying across the sky with Medea looking at the Sun. Similarly, the initial sequence between Jason and the centaur was used to introduce the modern spectator to the mythical reality to which Medea belongs and which, in the Greek world, belongs above all to women, children, and foreigners - to the Other. Pasolini succeeded in problematizing the issue of myth and Greek attitudes towards mythical reality, which is a dimension necessary for understanding this ancient drama. On the one hand, there is a myth about Medea that raises the question about the position of women and foreigners in a patriarchal society. Pasolini also puts into focus the cyclical concept of nature in which people express themselves through the ritual, perceiving themselves as a part of the natural and the cosmic totality. This is exactly the component used by Pasolini to introduce the problem of the modern European attitude towards the Other, above all in the wider social context - toward anyone who is not oriented to the progression of linear time and whose values therefore differ from those who dominate.

Although the film belongs to the mass media, Pasolini's Medea cannot be defined as a product of a popular culture, above all because people are not yet ready to face the problem of the Other. In that context I would like to mention the observation by Judith Butler that it is precisely the people excluded from society (women, foreigners, children) who make possible the existence of public space, from which they are, paradoxically, excluded. The problem of Otherness is raised in this drama by the act of violation of tabooed social norms, which are, according to Butler, closely related to and dependant on the state: ${ }^{33}$

Not only does the state presuppose kinship and kinship presuppose the state but "acts" that are performed in the name of the one principle take

33 Judith Butler, Antigone's Claim: Kinship between Life and Death (New York: Columbia University Press, 2000) 11-12. 
place in the idiom of the other, confounding the distinction between two at a rhetorical level and thus bringing into crisis the stability of the conceptual distinction between them.

It is possible that the collective unreadiness to confront the existing family or state value system is a reason that this (as well as other contemporary adaptations of Medea) are part of the high culture. The plot of Medea is too shocking, and it does not offer stereotypes that popular culture might use. Apart from that, this drama directly confronts the audience with violence and murder, making obvious that there are murders that are, on the one hand, socially acceptable and justified (like those in wars), and, on the other, those that are hypocritically judged - as if every violent death were not always about the death of someone's children and someone's closest kin.

\section{Works Cited}

Agamben, Giorgio. Homo Sacer, Sovereign Power and Bare Life (trans. Daniel HellerRoazen; Stanford, CA: Stanford University Press, 1998).

Allan, William. Euripides: Medea (London: Duckworth, 2002).

Butler, Judith. Antigone's Claim: Kinship between Life and Death (New York: Columbia University Press, 2000).

Čajkanović, Veselin. Studije iz srpske religije i folklora (Beograd: SKZ BIGZ, 1994).

Čale-Feldman, Lada. Euridikini osvrti : o rodnim izvedbama u teoriji, folkloru, književnosti $i$ kazalištu. (Zagreb: Naklada MD centar za ženske studije, 2001).

Christie, Ian. "Between Magic and Realism: Medea on Film," in Edith Hall, Fiona Macithosh, and Oliver Taplin, eds., Medea in Performance 1500-200o (Oxford: Oxford University Press, 2001).

Colombo, Furio. We are all in Danger, The Last Interview with Pier Paolo Pasolini, accessed November 28, 2011, http://www.leftcurve.org/LC3oWebPages/Pasolini's\%2oLast\%20 Interview.html.

Duflot, Jean. Entretiens avec Pier Paolo Pasolini (Paris: Pierre Belfond, 1970).

- Dernières paroles d'un impie: entretiens avec Jean Duflot (Paris: Pierre Belfond, 1981).

Flatley, Guy. “One Man's God, Another Man's Devil,” The New York Times (April 20, 1969) D15. [http://www.moviecrazed.com/outpast/pasolini.html]

Foley, Helene P. "Tragic Wives: Medea's Divided Self," in Female Acts in Greek Tragedy. (Princeton: Princeton University Press, 2001) 243-272.

Gordon, Robert S. C. Pasolini: Forms of Subjectivity (Oxford: Clarendon Press, 1996).

Harrison, Thomas. Greeks and Barbarians (Edinburgh: Edinburgh University Press, 2002).

Hazel, Ruth. "Electra: A Fragmented Woman," in L. Hardwick, ed., Theatre Ancient and Modern (Milton Keynes: Open University, 2000) 82-90, accessed November 28, 2011, http://www2.open.ac.uk/ClassicalStudies/GreekPlays/Conf99/hazel.htm.

Kristeva, Julia. "Women's Time," in Toril Moi, ed., The Kristeva Reader (New York: Columbia University Press, 1986) 187-213.

Loraux, Nicole. Mothers in Mourning, with an Essay of Amnesty and Its Opposite (Ithaca NY: Cornell University Press, 1998).

- The Mourning Voice, An Essay on Greek Tragedy (Ithaca NY: Cornell University Press, 2002). 
—. Tragic Ways of Killing a Woman, (Cambridge MA: Harvard University Press, 1987). MacKinnon, Kenneth. Greek Tragedy into Film (Rutherford NJ: Fairleigh Dickinson University Press, 1986).

Pache, Ondine Corinne. Baby and Child Heroes in Ancient Greece (Urbana IL: University of Illinois Press, 2004).

Rehm, Rush. Marriage to Death: The Conflation of Wedding and Funeral Rituals in Greek Tragedy (Princeton: Princeton University Press, 1996).

Rohdie, Sam. The Passion of Pier Paolo Pasolini (Blooomington IN: Indiana University Press, 1995).

Soyinka, Wole. Myth, Literature and the African World (Cambridge: Cambridge University Press, 1990).

Vernant, Jean-Pierre and Pierre Vidal-Naquet. Mit i tragedija u antičkoj Grčkoj (Beograd: n.p., 1995).

Zeitlin, Froma. Playing the Other (Chicago: The University of Chicago Press, 1996). 



\title{
"UNIVERSAL'S RELIGIOUS BIGOTRY AGAINST HINDUISM": ${ }^{1}$ GENDER NORMS AND HINDU AUTHORITY IN THE GLOBAL MEDIA DEBATE ON REPRESENTING THE HINDU GOD KRISHNA IN XENA: WARRIOR PRINCESS
}

\author{
Xenia Zeiler
}

\section{The Complex Gender Subtext of Xena: Warrior Princess}

Xena: Warrior Princess, the successful American fantasy franchise often described as "historical fantasy," has been referred to as a pop cultural phenomenon and its leading character Xena as a feminist and lesbian icon. The cult television series, which has aired in more than one hundred countries, opens up several remarkable points for discussion on filmtheory as well as gender-theoretical issues. This paper's analysis broaches the issues of gender, authority, and religion.

The TV series emerged as spin-off from the TV series Hercules: The Legendary Journeys (1995). ${ }^{2}$ Both series were produced by Sam Riami and Rob Tapert. Both were shot mainly at Auckland, New Zealand. But unlike Hercules: The Legendary Journeys, of course, its spin-off, Xena: Warrior Princess, features a strong female protagonist. Arising from a relatively marginal role at the time of her introduction as an enemy of Hercules in Hercules: The Legendary Journeys (Season One, Episode 9), Xena was developed in her own series as a complex, strong, determined, and surely independent character. Within the series featuring Hercules as the protagonist, the female character Xena remains very limited in many aspects. From her initial portrayal as one of the many opponents of the unquestioned (male) hero Hercules, she is in subsequent episodes (1.12-13) won over by him and becomes his ally. But in her very own domain, in the new series, she is developed as quite a different personality.

Throughout six seasons in a total of 134 episodes, she is repeatedly fighting against humans, gods, heroes, and other beings and creatures, but she continues as well in search of her own inner progress. She does so, and this is striking at first, without developing and maintaining important

\footnotetext{
1 Tusta Krishnadas (World Vaishnava Association spokesman), India-West, March 30, 1999, accessed November 30, 2011, http://lisatsering.tripod.com/xena33o.html.

2 The television series debuted in 1995. Five pilot films preceded it in 1994.
} 
relations to males. All the academic works on Xena I consulted agreed that she took over a hitherto male-dominated genre as action heroine in fantasy television shows. ${ }^{3}$ They understood her character to be much more "heroic,"4 "empowering,"5 "physically strong," ${ }^{\text {and }}$ "strong psychologically and emotionally,"7 than those of her male counterparts in the series. And Xena was especially described as "tough." ${ }^{8}$ Without doubt, she is self-sufficient when it comes to males. In general, female leading figures, "tough girls" 9 and "action chicks"10 dominate the plots. Xena's teachers and guides, for instance, M'lila or Lao Ma, are female, and even her most intelligent enemies (for instance, Callisto) are female as well. As a female action hero, Xena "crosses multiple boundaries," ${ }^{11}$ and she "represents a turning point in the portrayal of women in fantasy television." ${ }^{12}$ Female fans in particular approved, and several empirical studies pointed out that a large percentage of the audience for Xena: Warrior Princess was female. ${ }^{13}$ The Raimi/Tappert series successfully depicted Xena as a warrior: she kills hostiles and leads entire armies. But more remarkable, surely, is the detailed portrayal and discussion of the complex facets of Xena's inner (female) landscape in the series. To a significant extent this is what attracted such large an audience to the series, and this is what kept it in production for six seasons. The complex gender subtext of the series and the constant inner (emotional and ethical) struggles of the female leading

3 This turn in the portrayal of women as though, fighting and even violent in recent film history, of course, is limited neither to television nor to fantasy. For an overview of violent women in the American film, see Hilary Neroni, The Violent Woman: Femininity, Narrative, and Violence in Contemporary American Cinema (New York: State University of New York Press, 2005) 15-40.

4 Sharon Ross, "'Tough Enough': Female Friendship and Heroism in Xena and Buffy," in Sherrie A. Inness, ed., Action Chicks: New Images of Tough Women in Popular Culture (New York: Palgrave Macmillan, 2004) 232.

5 Sara Crosby, "The Cruelest Season: Female Heroes Snapped into Sacrificial Heroines," in Inness, Action Chicks, 169.

${ }^{6}$ Sherrie A. Inness, Tough Girls: Women Warriors and Wonder Women in Popular Culture (Philadelphia: University of Pennsylvania Press, 1999) 167.

7 Ross, “'Tough Enough,” 233.

8 Inness, Tough Girls, 161, and Ross, “'Tough Enough,” 232.

9 Inness, Tough Girls.

10 Inness, Action Chicks.

11 Charlene Tung, "Embodying an Image: Gender, Race, and Sexuality in La Femme Nikita," in Inness, Action Chicks, 99.

12 Steven Savile, Fantastic TV: 50 Years of Cult Fantasy and Science Fiction (London: Plexus Publishing Limited, 2008) 206.

13 See, for instance, Mohini Krischke-Ramaswamy, Populäre Kultur und Alltagskultur: funktionelle und ästhetische Rezeptionserfahrungen von Fans und Szenegängern (Konstanz: UVK-Verlagsgesellschaft, 2007) 133, or Nikki Stafford, How Xena Changed Our Lives: True Stories by Fans for Fans (Toronto: ECW Press, 2002) 182. 
character were intensively discussed by fans, ${ }^{14}$ especially on the Internet, in a large number of blogs, ${ }^{15}$ fan sites, ${ }^{16}$ fan club sites, ${ }^{17}$ chat rooms, ${ }^{18}$ and forums. ${ }^{19}$

Important for a large section of this audience as well as for this paper is a specific gender subtext in Xena: Warrior Princess. We find a lesbian subtext in the series; it is implied in the basic structure of the series. Gabrielle, Xena's best friend and permanent companion, possibly shares a lesbian relationship with the heroine. The series toys with this potential constantly, and it does so in a very intriguing and sensitive manner at the same time. Part of the intrigue is that it never clarifies the situation but leaves space for ambiguity right until the last episode. Maybe (and, in my opinion, most likely) it was exactly this originality in the gender subtext of the plot, the indication of a lesbian relationship instead of its full disclosure or conclusive denial, that kept the fascination going for a considerable part of the audience. The implied lesbian subtext of the series was, not surprisingly, discussed widely and variably interpreted by fans. Many of these discussions indeed took a sexual relationship between Xena and Gabrielle for granted, ${ }^{20}$ and they debated more the specific nature of this relationship than its mere existence. ${ }^{21}$ It surely is a large thrill-factor in the series for an audience not interested primarily in the much quoted action horizon. But, as we shall see, especially this

14 For a discussion of the communication habits among fans of Xena:Warrior Princess, see, for instance, Krischke-Ramaswamy, Populäre Kultur und Alltagskultur, $145^{-150 .}$

15 See, for instance, http://www.xenafan.com/, accessed November 30, 2011.

16 See, for instance, http://www.warriorprincess.com/, accessed November 30, 2011.

17 See, for instance, http://www.creationent.com/outback/fanclubs/, accessed November 30, 2011.

18 See, for instance, http://talkingxena.yuku.com/, accessed November 30, 2011.

19 See, for instance, http://www.xenaforum.de.vu/, accessed November 30, 2011.

20 For an empirical study on this topic focussing on the lesbian and gay audience of Xena: Warrior Princess, see, for instance, Walter Alesci, "Xena: Warrior Princess Out of the Closet? A Melodramatic Reading of the Show by Latin American and Spanish Lesbian and Gay Fans," in Rikke Schubart and Anne Gjelsvik, eds., Femme Fatalities. Representations of Strong Women in the Media (Göteborg: Nordicom, 2004).

21 For the interpretation of Xena and Gabrielle as a butch-femme couple by the audience, see, for instance, Rikke Schubart, Super Bitches and Action Babes: The Female Hero in Popular Cinema, 1970-2006 (Jefferson NC: McFarland \& Company, 2007) 219. For contrasting Xena's destructive side with Gabrielle's constructive side, see, for instance, Kathleen Kennedy, "Love Is the Battlefield: The Making and the Unmaking of the Just Warrior in Xena, Warrior Princess," in Early and Kennedy, Athena's Daughters, 41-47. For a detailed discussion of Xena's sexual violence in especially online fiction, see Helen Caudill, "Tall, Dark, and Dangerous: Xena, the Quest, and the Wielding of Sexual Violence in Xena OnLine Fan Fiction," in Early and Kennedy, Athena's Daughters, 27-39. 
subtext of the series was inevitably regarded as a matter of concern by a number of religious organizations.

\section{Hindu Religious Traditions in Xena:}

Warrior Princess - Krishna and the Bhagavadgita

The plot of the series is set in a broad mythological frame covering a wide variety of historical epochs, religious traditions, and geographical regions. Various mythological figures, heroes, and gods are adapted and brought into this frame. Xena fights her way through all of this, using her own distinctive style of fighting and her unique weapon, the Chakram. ${ }^{22}$ The storylines of the episodes are freely based on either ancient traditions or religions (the story then often loosely makes use of historical facts), wellknown mythologies and legends, or pure fiction. Historical individuals, like Julius Caesar, appear in the series, as well as mythological heroes like Hercules and gods like Zeus. Not surprisingly, by far the most episodes borrow from epochs, traditions, religions, and geographical areas widely known to a particularly Western audience. Ancient Greek, Roman, or even Egyptian epochs, traditions, and religions are often portrayed and referenced, and the producers also repeatedly draw on Christian and Jewish traditions. Only very seldom do we find references to Asian contexts. In the rare instances that they are introduced into the series, they refer mainly to East Asian traditions - particularly to ancient or medieval Chinese or Japanese warrior traditions. ${ }^{23}$ Merely three episodes of Xena: Warrior Princess are set in a Hindu mythological context. However, one of these episodes caused unexpectedly controversial and heated public debate. The episode, "The Way" (4.16), ${ }^{24}$ created a heave of protest from a considerable number of Hindu organizations based in the United States and in India, which the production team obviously had not anticipated. Subsequently, this concern was intensely and at times passionately discussed in different media genres, especially on the Internet. The issue had far-reaching consequences and in the end led to the introduction of a pro-

22 The Chakra is considered a very potent weapon in Hindu mythology and is especially connected to the god Vishnu. For a discussion of this topic in Hindu mythology and art, see W. E. Begley, Viṣnu's Flaming Wheel: The Iconography of the Sudarśana-Cakra (New York: New York University Press, 1973).

${ }^{23}$ For a short introduction in this topic, see Kennedy, "Love Is the Battlefield," 47-52.

24 "The Way" was first released on February 22, 1999. It was shot in December, 1998. 
duction code, a self-imposed censorship by the production management of Xena: Warrior Princess at Universal Studios.

"The Way" is (very) loosely based on the Hindu epics Ramayana and Mahabharata. It stages mythological figures - gods, but also one demonlike figure - from both epics. The main characters introduced here are Indrajit (from the Ramayana), Hanuman (from the Ramayana), Krishna (from the Mahabharata), and Kali (who does not figure in the epics but is very popular in recent Hinduism and, presumably, also known to a large part of the Western audience). The only (but nevertheless very potent) "evil" character out of these four in Hindu mythology is Indrajit, who is analogously depicted as an enemy of Xena and her allies in the series. Thus, in the episode's context, only one out of four figures from the Hindu pantheon is depicted as malevolent. But again, this still stays exactly in line with the mythological context of the Ramayana, where Indrajit is understood as "evil" and demon-like. Indrajit is the least-known figure out of the Hindu characters portrayed here. He never rose into a prominent position in the Hindu pantheon beyond the mythology of the Ramayana.

The episode begins revealing the evil of Indrajit right from the outset. Gabrielle is in danger, kidnapped by Indrajit, who threatens to kill her unless Xena intervenes to save her. On her way to free Gabrielle (and to battle Indrajit, of course) Xena gets into touch with the Hindu gods, one after the other. She first meets Hanuman, who advises her to ask Krishna for help. Calling him the supreme personality of the godhead, he convinces Xena that he is the key in the fight against Indrajit. But arriving at Krishna's temple, Hanuman holds a surprise for Xena. Only by praying to Krishna, he reveals, will the god listen and appear. Xena is used to opposing the gods rather than honoring them, so she is skeptical. But because she believes Hanuman, who convinces her that Krishna is her only hope against Indrajit, and because her love for Gabrielle compels her, she agrees and starts to pray to Krishna. The god appears, and a very personal, intense conversation between the two takes place. Basically, Krishna strengthens Xena, who at this point in the series is also beginning to have doubts about her life as a warrior. Using arguments of rebirth and karma, Krishna encourages her to fight:

Xena: Krishna?... Krishna? Thank you for coming. Where's Hanuman?

Krishna: I asked him to step outside. I thought it best that we be alone for this.

Xena: What? We are going after Eli and Gabrielle, right?

Krishna: How do you expect to defeat Indrajit?

Xena: I can't without your help. 
Krishna: But I can't help you ... unless you let me.

Xena: I'm not one for cryptic talk... Get to the point.

Krishna: You must open up your heart to me, if you are going to tap into the strength that will allow you to defeat Indrajit.

Xena: I thought that's what the prayers were for?

Krishna: That got my attention. Now ... you have to go one step further. You have to embrace the Way.

Xena: The Way? I've heard about the Way in Greece, Chen, Anatoli, and now India. I don't get it... The Way is not for people like me.

Krishna: You're wrong... You're very close to the Way now. However, missing it by the width of a hair is the same as missing it by the height of a mountain. Xena: I'm close? I don't think so. I don't have the patience of Gabrielle, the love of Eli, or the serenity of my mentor, Lau Mah. I'm just an angry asskicking...

Krishna: Warrior.

Xena: Yes, a warrior.

Krishna: You say that with disgust.

Xena: Well it doesn't rank up there with the saints, does it?

Krishna: Xena... You have seen what you're destined to be. In your next life you will walk the Way of the saint.

Krishna: You will never achieve that life if you don't follow that Way that you're on now.

Xena: The Way of the Warrior?

Krishna: Yes...You must not be hesitant to fight in a just cause. It is better to die following your own Way than it is following someone else's. When you ride into combat, act without detachment and carry with you the confidence that you are fulfilling your calling in this life. Then you will know the Way.

Xena: I understand...

Krishna: Then go... Rise up like fire and burn all that oppose you. And if you're following the path of the Way, call my name and the strength to defeat Indrajit will be given to you. Are you ready?

Xena: I'm ready.

This conversation, especially the last part, reads almost as if drawn from the Mahabharata and, to be exact, from the Bhagavadgita. ${ }^{25}$ The arguments stay very close to the original source. At one of the crucial points in the frame-story of the Mahabharata, Krishna instructs the doubtful warrior Arjuna to fight, and in this context he reveals the Bhagavadgita. Arjuna in the Mahabharata is the leading archer in the army of the Pandavas, a group of five brothers fighting a battle against their reigning cousins,

25 For a translation of the complete Bhagavadgita, see, for instance, J.A.B. van Buitenen, The Bhagavadgita in the Mahabharata: Text and Translation (Chicago: University of Chicago Press, 1981). 
the Kauravas. Both parties have clearly assigned roles in the Mahabharata. The righteous, brave Pandavas have no choice but to fight the evil, greedy Kauravas for the throne. Of course, this conflict has to be interpreted in a larger scope - for instance, in the mythological story of the Mahabharata, it is essential to initiate a final battle between virtue and evil, a battle to secure righteousness not only in the kingdom but in the universe itself. At the very beginning of this battle, Arjuna, who is usually depicted as a heroic warrior, is overwhelmed by doubts about the battle's justness and, basically, by scruple. He does not want to kill his relatives and venerated teachers on the Kauravas' side. At this point, in between the two armies ready to start the battle, Arjuna refuses to fight. His charioteer Krishna, depicted throughout the Mahabharata as friend and guide of the Pandavas, starts to instruct Arjuna about the duty of warriors. This is where Krishna reveals the Bhagavadgita is interpolated.

The Bhagavadgita, the "Song of the Lord," is an interpolation in the Mahabharata and may be and often is seen as a self-contained script. In the form of an instruction, Krishna reveals several central aspects of dharma and faith, which have been essential to most Hindu religious traditions up to the present. Krishna teaches about the nature of dharma in the world, about rebirth and karma, about detachment to one's actions and, most important, about the necessity to follow the path into which one is born. Along with this come teachings about the possible ways to god and practical directions on social and ritual behavior. Probably the most important teaching of the Bhagavadgita (besides the prominent instructions on duty) is bhakti - unconditional, emotional, self-surrendering love for Krishna. ${ }^{26}$ Early in the episode, Xena has been made aware of this essential concept of the Bhagavadgita by Hanuman, who encourages Xena to pray to Krishna. And Krishna himself (only after Xena proved her acceptance of bhakti by praying), introduces Xena to a kind of short version of the Bhagavadgita's teachings.

Following the first encounter with Indrajit, Hanuman, and the central conversation between Krishna and Xena in "The Way," towards the end of the episode there is a fourth encounter of a different nature with another figure from the Hindu pantheon. After Xena accepted Krishna's encouragement and instruction, she seeks battle with Indrajit. But her own combat skills are not enough, and she is near death. We have to recall at

${ }^{26}$ For an informative collection of articles highlighting different aspects of bhakti, see Karel Werner, ed., Love Divine: Studies in Bhakti and Devotional Mysticism (Richmond: Curzon Press, 1993). 
this point that Xena is battling Indrajit to rescue Gabrielle. Xena's defeat would mean she failed Gabrielle, and Xena's death would result in Gabrielle's death as well. It seems that this is the reason why Xena decides to call on Krishna again. She does so only at the very last moment before dying, whispering Krishna's name. And as Krishna promised, he is there to help. He transforms Xena into a figure very much resembling the Hindu goddess Kali. The iconography is unmistakable. The long, red, protruding tongue, the hairstyle, and all the other attributes of the figure clearly indicate Kali. Xena now rises, multi-armed, equipped with several weapons, and obviously endowed with a potential of extremely powerful energy. In this new form Xena succeeds in killing Indrajit in direct combat. She immediately reverts to her own form, which marks the end of the battle.

Interestingly, this transformation of the action heroine into a very popular Hindu goddess, brought about by a Hindu god, did not meet with publicly expressed concerns from Hindu organizations. This very intimate encounter of Xena with a Hindu deity, the implied rise of Xena to the position of a goddess, and her temporary incorporation in the Hindu pantheon, did not cause agitation or protest. ${ }^{27}$ Where a Western public might see potential for concern, no complaint arose. Where, from a Western perspective, the transformation of Xena into Kali may be understood as a very liberal incorporation of a deity from a living religious tradition into a fantasy plot of a television series, Hindu believers and organizations obviously felt no need to interfere. Also the depiction of Hanuman and Indrajit in the episode found no negative reaction. What caused a very strong and far-reaching protest from several Hindu organizations was the representation of Krishna.

\section{"Lord Krishna is not a fictional character that you can just put words in his mouth"28}

Both the Ramayana and Mahabharata, but also especially the Bhagavadgita, are texts extremely well-known and revered in Hinduism. The

27 On the contrary, this portrayal was even publicly defended. See Hinduism Today, June, 1999, accessed November 30, 2011, http://www.hinduismtoday.com/modules/smartsection/item.php?itemid=4398.

28 Tusta Krishnadas, spokesman for the World Vaishnaiva Association, on March 5th, 1999, in an interview with Lisa Tsering, Staff Reporter from India-West, the largest weekly newspaper in the United States for news from South Asia, http://lisatsering.tripod.com/ xena35.html, accessed November 30, 2011. 
teachings and doctrines of both epics, as well as the mythologies and their protagonists, are repeatedly recited (at religious functions and secular gatherings), recounted (written in literature and orally retold for family and friends), drawn (for example, in comics), and filmed (for both cinema and television). In sum: they are known to virtually every Hindu from a very young age on. Hanuman and Krishna have both been depicted in a large number of important and acknowledged religious texts also beyond the epic period; today they belong to the most popular gods in Hinduism. Kali is one of the most influential and well-known goddesses of presentday Hinduism. In "The Way," it would seem, the production team decided to incorporate several dimensions of influential (if not dominant) perceptions of modern Hinduism. The episode interlaces basic orientations or teachings of the Bhagavadgita in the plot, namely, rebirth, karma, dharma (duty and/or obligation, in "The Way" as in the Bhagavadgita explicitly elucidated by using the warrior's duty as an example), and bhakti. It depicts three of the most popular Hindu deities and ventures into the sphere of action and character attributed to them. Out of the four figures mentioned, certainly Krishna is the most popular and influential deity in recent Hindu traditions. ${ }^{29}$

From a Western perspective, again, at first, there does not seem to be much reason for criticism of the representation of the Hindu deity Krishna in "The Way." If we presume that deities in general can be interwoven into plots of fantasy stories or television series, particularly if the deities are central to living religious traditions, then, apparently, Krishna's depiction in "The Way" would seem to have been the result of an attempt to be respectful to Hindu religious traditions. The production team obviously did its homework by reading up on the Bhagavadgita, Mahabharata, and Ramayana. A well-known Hindu academic professor even served as consultant. $^{30}$ The iconography of the deities (and the "villain") from the Hindu mythological tradition seemed to have been accurately portrayed in the episode, a point which was frequently applauded, especially by fans. In summary, the plot and visual representations of the story's protagonists pointed toward a very well-informed production team. Nothing, then, signalized trouble ahead, especially for this episode.

29 For Krishna's development in important Hindu textual sources from the Mahabharata on, see Freda Matchett, Krṣna: Lord or Avatāra?: The Relationship Between Krṣna and Viṣnu (London: Routledge, 2001).

30 Ravi Arvind Palat at present is Professor of Sociology at the State University of New York. 
The representation of Krishna nevertheless created a number of protests from several Hindu organizations, especially from diaspora organizations based in the United States and New Zealand, but also from India, which the production team clearly had not anticipated. Officially the discussion in the world-wide press and, especially, on the Internet, started with severe criticism from an influential American-based Hindu organization. The World Vaishnava Association, which not only initiated the protest against "The Way" but also continued to lead it during the following debate, was founded in 1994 as a federation to promote internationally the devotion of Krishna. ${ }^{31}$ It sees itself as an organ for more than one hundred Hindu groups worldwide, including the influential Vishwa Hindu Parishad and the Overseas Friends of the BJP. The World Vaishnava Association's primary concern about the episode focused on Krishna's portrayal as a fictional character, as Tusta Krishnadas, spokesman for the association, expressed it: ${ }^{32}$

Lord Krishna is not a fictional character that you can just put words in his mouth. Even if he is presented as good or nice, you don't treat the Supreme Godhead that way.

Fictionalizing Krishna and the way this supposedly degrades or "cheapens and trivializes" the deity, continued to be the main point of contention for the association and various organizations expressing their solidarity with it. ${ }^{33}$ This concern dominated the public debate about "The Way." But alongside this, also right from the beginning of the debate, a second topic was raised in a parallel discussion by the World Vaishnava Association.

This second concern as well was supported by several other diasporabased organizations, such as the American Hindus Against Defamation, the New Zealand School of Meditation, the Wellington Indian Association, and the Chaitanya Mission of Los Angeles:

"The episode is offensive in two ways," said Krishnadas. "One, it treats Lord Krishna, the Supreme Personality of Godhead, speaker of the Bhagavad Gita, as fictional. Two, it makes it appear that Lord Krishna and Vedic religion approves of and gives its blessing to homosexual relationships,

31 For the self-introduction of the World Vaishnava Association, see http://www.wvavvrs.org/, accessed November 30, 2011.

32 Tusta Krishnadas, spokesman for the World Vaishnaiva Association, on March 5th, 1999, interviewed by Lisa Tsering for India-West, http://lisatsering.tripod.com/xena35.html, accessed November 30, 2011.

33 Ajay Shah of the American Hindus Against Defamation, on March 5th, 1999, interviewed by Lisa Tsering for India-West, http://lisatsering.tripod.com/xena35.html, accessed November 30, 2011. 
which is false."... Krishnadas commented, “'Xena' increasingly tries to link itself with spirituality and yoga but simultaneously promotes a lesbian relationship between the lead characters. This is an absolute outrage since Vedic scriptures, the scripture of yoga, reject homosexuality as a perversion." 34

This second objection seems crucial to me. The World Vaishnava Association takes a sexual relationship between Xena and Gabrielle for granted and brings up the issue in public. This statement reveals a very clear notion concerning gender norms and, more specifically, also sexual norms. The World Vaishnava Association and the supporting organizations disapprove of the series' lesbian subtext, and judging from the information in this statement, it even seems most likely that especially for that reason they also disapprove of Hindu deities (and even concepts, such as yoga) being involved in Xena: Warrior Princess. Considering the integration of the two arguments, it is very surprising that this second argument for the most part bypassed the public awareness in the debate on "The Way." It played nearly no role in the media discussion. ${ }^{35}$ And it was barely disputed by fans in public. ${ }^{36}$ Also, the most important result arising from the debate on "The Way" - the aforementioned temporary imposition of a production code, a self-imposed censorship by Unversal Studios - was not officially connected to the concerns of the World Vaishnava Association with homosexuality or with gender issues in general.

We may only guess why this argument disappeared from the public discussion soon after it was stated. The reasons why this specific controversy between Hindu organizations and Universal Studios was removed from public view has not been explained by either side. But it seems that both parties, eventually, wanted to avoid discussing this sensitive issue in public. The World Vaishnava Association and its supporters may not have wanted to further stress a strong homophobic argument, especially in the Hindu diaspora context. On the other side, Universal Studios may have wanted to keep up its ambiguous toying with a possible lesbian

34 Interview of Lisa Tsering for India-West with Tusta Krishnadas on March 5th, 1999, http://lisatsering.tripod.com/xena35.html, accessed November 30, 2011.

35 For one example of public response to the controversy, see the open letter by Ravi Arvind Palat, official counselor for the episode, http://www.warriorprincess.com/way protest.shtml\#furor, accessed November 30, 2011.

36 For one example of a discussion on this topic and a statement of Universal Studios on the issue, see http://www.warriorprincess.com/wayprotest.shtml\#tapert, accessed November 30, 2011. 
relation between Xena and Gabrielle instead of fully acknowledging it in a public discussion, which would probably have been necessary in responding to the concerns expressed by the World Vaishnava Association. By defining the relationship as lesbian, the series would have most likely drawn unwanted attention from a larger homophobic public in general. De facto, the media discussion on this topic ended with a withdrawal of the comment on homosexuality by the World Vaishnava Association. All arguments leading to the production code after this focused on the representation of Krishna as fictional character.

The development which finally led to the production code officially began shortly before the episode was first aired in February, 1999. The World Vaishnava Association ${ }^{37}$ as well as the American Hindus Against Defamation $^{38}$ submitted letters to Renaissance Pictures demanding detailed information about the rumored representation of Krishna and a suspension of that episode in case this was indeed in production. Renaissance Pictures and Universal Studios confirmed the production of such an episode, stressed their respectful intentions, and decided to air it as planned. Thus, at the time of the first airing, there already was media attention about the issue, backed by interviews and statements from Hindu organizations in several newspapers and magazines. The controversy then climaxed in protest rallies by several Hindu organizations, which were held in addition to the ongoing media discussion.

The passionate reproaches against Universal Studios went along with explicit demands. The World Vaishnava Association demanded three things from the show's production and distribution entities - Renaissance Pictures, Universal Studios, and Studios USA: a public apology to offended Hindus, the irrevocable withdrawal of the episode from all public airings, and the promise to never fictionalize Krishna or other Hindu deities in Xena: Warrior Princess or its partner show Hercules: The Legendary Journeys in the future. ${ }^{39}$ The rallies were ignored by Universal Studios at first, which again caused very strong reactions from the protesters. These reactions even went so far as to accuse Universal Studios of racism and religious discrimination. One report described the Hollywood protest: ${ }^{40}$

${ }^{37}$ For the complete letter, see http://hindunet.org/ahad/xena/wva_letter.shtml, accessed November 30, 2011.

38 For the complete letter, see http://www.hindunet.org/anti_defamation/xena/ahad_ letter.shtml, accessed November 30, 2011.

39 See http://lisatsering.tripod.com/xena319.html, accessed November 30, 2011.

40 Lisa Tsering for India-West, http://lisatsering.tripod.com/xena319.html, accessed November 30, 2011. 
An estimated 150 protesters were turned away from Universal Studios in North Hollywood, Calif., Mar. 15, as they rallied to demand an apology from the producers of "Xena: Warrior Princess." The protesters, representing over 70 Hindu organizations worldwide, say the television show offended Hindus by portraying Krishna as a fictional character in a recent episode. Security guards blocked them from entering the studio grounds... "They ignored us," Tusta Krishnadas, of the World Vaishnava Association, told India-West. "This is an outrage. It smacks of both racism and religious discrimination."

Another added:41

They spit in the face of Hindus all over the world.

Not surprisingly this public outrage compelled Universal Studios to act. At first the studio tried to smooth the waters by issuing pacifying statements, again stressing the producer's respectful intentions in portraying Hindu religion. But more massive protest rallies followed, and posters as well as slogans again very explicitly criticized Universal Studios by charging, for instance, "Universal's religious bigotry against Hinduism."42 This persistent public outcry from several Hindu organizations worldwide, manifested by a global media debate on the issue as well as in protest rallies in Hollywood right before the producers' doors, resulted in the selfimposed censorship by Universal Studios and Renaissance Pictures. On April 2, 1999, about five weeks after its first airing, the episode was pulled from worldwide syndication. The respective statement of Universal Studios mentioned one single reason for this, and that was that the producers wanted to react to the severe protests against portraying Krishna as a fictional character. ${ }^{43}$ The lesbian subtext of the series was not referred to in this context. Nevertheless, judging from the analysis above, it seems arguable that the episode was withdrawn primarily out of respect for a group of offended Hindus. Renaissance Pictures might as well have been concerned that the ongoing worldwide media debate drew unwanted broad public attention to the lesbian theme of the series.

Even though the production code was introduced and the episode was withdrawn, this was not yet the end of the story. At this point, a massive countermovement was initiated by fans of Xena: Warrior Princess,

\footnotetext{
41 Tusta Krishnadas interviewed by The Hollywood Reporter on March 19th, 1999, http:// www.allbusiness.com/services/motion-pictures/4829944-1.html, accessed November 30, 2011.

42 Slogan decried by Tusta Krishnadas in the protest rally on March 28th, 1999, see, for instance, http://lisatsering.tripod.com/xena33o.html, accessed November 30, 2011.

${ }^{43}$ For the statement of Universal Studios, see http://www.warriorprincess.com/way protest.shtml\#statement, accessed March 15, 2011.
} 
a movement which reacted against alleged censorship in the series. ${ }^{44}$ This countermovement was organized especially on the Internet. ${ }^{45}$ Several Internet petitions were created, and, no doubt because of this fan-protest, only five months later, on August 3oth, 1999, Universal Studios decided to air "The Way" again on television. ${ }^{46}$ Remarkably, as it turned out, the production team - obviously concerned about the economic impacts of the withdrawal - had already inserted into its former statement announcing the production code itself an escape clause that would allow for a potential later reairing. A short sentence was included in this statement promising a collaboration with a counselor for questions about the Hindu context. It was explicitly stated that, if the episode was to be re-aired, Sunil Aghi, founder and president of the Indo-American Political Foundation, would be consulted regarding the specific alterations.

The self-declared authority of the World Vaishnava Association and its supporters as speakers for all Hindus was thereby undercut by replacing it with another Hindu authority, which like the World Vaishnava Association is specifically based in the United States. The Indo-American Political Foundation is a group of non-resident Indians (NRI) primarily working to create political and governmental awareness for the needs of the Indian community in the United States. The organization also supports political candidates to promote this issue and strives toward educating NRI living in the United States about the American political system in general. Aims and objectives of this organization, obviously, differ considerably from those of the World Vaishnava Association and surely attract a very different interest group. The Indo-American Political Foundation, therefore, represented another category of Hindu perspective and, as such, was consulted by Renaissance Pictures as an alternative Hindu authority.

With Sunil Aghi as new counselor, the reedited episode introduced two significant interpolations ${ }^{47}$ First, a written statement in the title sequence opens the episode:

44 For instance, the spokeswomen of "Xenites Against Censorship," an Internet-based fan group, declared in an interview with India-West on August 2oth 1999: "I frankly have never seen so many diverse locations joined with a common (cause)," http://lisatsering .tripod.com/xena820.html, accessed November 30, 2011.

45 See, for instance, http://www.angelfire.com/ar/beogodeo/theway.html, or http:// www.poky.net/xac/xac.html, both accessed November 30, 2011.

46 See, for instance, http://www.warriorprincess.com/wayprotest.shtml\#petition, accessed November 30, 2011.

47 For an introduction to his political ambitions, see http://timesofindia.indiatimes .com/home/sunday-toi/Our-man-in-the-US/articleshow $/ 26366404 . \mathrm{cms}$, accessed November 30, 2011. 
The producers of the following episode took liberties with Hindu deities and historical timelines, but their sole intent was to illustrate the beauty and power of the Hindu religion.

Second, a half-minute, filmed afterword with Lucy Lawless (Xena), Renée O' Connor (Gabrielle), and Sunil Aghi, concludes the episode:

Xena: In today's episode Xena prayed to Krishna the supreme godhead of Hinduism. We hope that we have portrayed it in a revered and respectful way.

Aghi: My name is Sunil Aghi. I am the community activist and president of the Hindu American political foundation.

Gabrielle: More than a billion people throughout the world practice the Hindu religion.

Aghi: An accurate portrayal of our deity is important to us, but an even more important goal is to enlighten people of other faith about Hinduism.

Gabrielle: With understanding comes tolerance.

Xena: If you would like to learn more about this great religion please visit your local library or Internet web site. ${ }^{48}$

Thus, by replacing the self-declared authority of the World Vaishnava Association and its supporters with another authority on Hindu religion, Universal Studios thought to legitimate "The Way" as well as to evade any further discussion on the issue. On a larger scale, this move clearly also negotiated Hindu authority in the United States, accentuating the authority of one Hindu organization above another in a debate that attracted large public interest. It is difficult to estimate the impact of this maneuvering, particularly in the Hindu community, but what is certain is that the episode was finally reaired after months of passionate debate, protest rallies, temporary withdrawal, and then final reediting. Apparently Xena is capable of vanquishing her opponents in a global media debate, just as in battle.

To sum up on gender norms and negotiating Hindu authority in the global media debate on "The Way": Krishna's representation in the series obviously disclosed a far-reaching potential for controversy, which was also based on divergent interpretations of gender norms by producers and fans of Xena: Warrior Princess and several diaspora-based Hindu organizations claiming authority for all Hindus. A very important point of offense in this context was the aid given by Krishna to the alleged lesbian couple Xena and Gabrielle. This concern with the lesbian subtext of the series

48 Complete transcription of the trailer. 
and, in general, the divergent understanding of gender norms was deemphasized in the course of debate, but in the end provoked a production code, a self-imposed censorship by Universal Studios. This step, in return, stirred a global media debate on how to acknowledge requests of religious communities in the series in general. Thus, the complexity of problems which arose from the production code expanded beyond the discussion of gender and/or religious norms and authority regarding explicitly Hindu traditions, and developed a much broader character. After only five months, the episode was aired again in a reedited form. This was largely rendered possible by Universal's engagement of an alternative Americanbased Hindu organization as counselor for questions on Hindu religion and mythology. By introducing a new Hindu authority in the debate, the producers not only opposed the authority of the protest organizations, but clearly also influenced and shaped the negotiation of Hindu authority in the United States in general.

\section{Works Cited}

Alesci, Walter. "Xena: Warrior Princess Out of the Closet? A Melodramatic Reading of the Show by Latin American and Spanish Lesbian and Gay Fans," in Rikke Schubart and Anne Gjelsvik, eds., Femme Fatalities: Representations of Strong Women in the Media (Göteborg: Nordicom, 2004) 203-218.

Begley, W.E. Viṣnu's Flaming Wheel: The Iconography of the Sudarśana-Cakra (New York: New York University Press, 1973).

Caudill, Helen. "Tall, Dark, and Dangerous: Xena, the Quest, and the Wielding of Sexual Violence in Xena On-Line Fan Fiction," in Frances H. Early and Kathleen Kennedy, eds., Athena's Daughters: Television's New Women Warriors (New York: Syracuse University Press, 2003) 27-39.

Crosby, Sara. "The Cruelest Season: Female Heroes Snapped into Sacrificial Heroines," in Sherrie A. Inness, ed., Action Chicks: New Images of Tough Women in Popular Culture (New York: Palgrave Macmillan, 2004) 153-180.

Inness, Sherrie A. Tough Girls: Women Warriors and Wonder Women in Popular Culture (Philadelphia: University of Pennsylvania Press, 1999).

Kennedy, Kathleen. "Love Is the Battlefield: The Making and the Unmaking of the Just Warrior in Xena, Warrior Princess," in Early and Kennedy, Athena's Daughters, 40-52.

Krischke-Ramaswamy, Mohini. Populäre Kultur und Alltagskultur: funktionelle und ästhetische Rezeptionserfahrungen von Fans und Szenegängern (Konstanz: UVK-Verlagsgesellschaft, 2007).

Matchett, Freda. Kṛṣna: Lord or Avatāra?: The Relationship Between Kṛ̣ṇa and Viṣnu (London: Routledge, 2001).

Neroni, Hilary. The Violent Woman: Femininity, Narrative, and Violence in Contemporary American Cinema (New York: State University of New York Press, 2005).

Ross, Sharon. "Tough Enough': Female Friendship and Heroism in Xena and Buffy," in Sherrie A. Inness, ed., Action Chicks: New Images of Tough Women in Popular Culture (New York: Palgrave Macmillan, 2004) 231-256.

Savile, Steven. Fantastic TV: 50 Years of Cult Fantasy and Science Fiction (London: Plexus Publishing Limited, 2008). 
Schubart, Rikke. Super Bitches and Action Babes: The Female Hero in Popular Cinema 19702006 (Jefferson NC: McFarland \& Company, 2007).

Stafford, Nikki. How Xena Changed Our Lives: True Stories by Fans for Fans (Toronto: ECW Press, 2002).

Tung, Charlene. "Embodying an Image: Gender, Race, and Sexuality in La Femme Nikita," in Inness, Action Chicks, 95-122.

van Buitenen, J.A.B. The Bhagavadgita in the Mahabharata: Text and Translation (Chicago: University of Chicago Press, 1981).

Werner, Karel, ed. Love Divine: Studies in Bhakti and Devotional Mysticism (Richmond: Curzon Press, 1993).

\section{Websites}

http://lisatsering.tripod.com/xena33o.html

http://www.xenafan.com/

http://www.warriorprincess.com/

http://www.creationent.com/outback/fanclubs/

http://talkingxena.yuku.com/

http://www.xenaforum.de.vu/

http://www.hinduismtoday.com/modules/smartsection/item.php?itemid= 4398

http://lisatsering.tripod.com/xena35.html

http://www.wva-vvrs.org/

http://www.warriorprincess.com/wayprotest.shtml\#furor

http://www.warriorprincess.com/wayprotest.shtml\#tapert

http://hindunet.org/ahad/xena/wva_letter.shtml

http://www.hindunet.org/anti_defamation/xena/ahad_letter.shtml

http://lisatsering.tripod.com/xena319.html

http://www.allbusiness.com/services/motion-pictures/4829944-1.html

http://www.warriorprincess.com/wayprotest.shtml\#statement

http://www.angelfire.com/ar/beogodeo/theway.html

http://www.poky.net/xac/xac.html

http://www.warriorprincess.com/wayprotest.shtml\#petition

http://timesofindia.indiatimes.com/home/sunday-toi/Our-man-in-the-US/articleshow/26366404.cms

http://lisatsering.tripod.com/xena82o.html 

MYTHOLOGICAL AND HISTORICAL THEMATICS 



\title{
ANCIENT WOMEN'S CULTS AND RITUALS \\ IN GRAND NARRATIVES ON SCREEN: \\ FROM WALT DISNEY'S SNOW WHITE TO \\ OLGA MALEA'S DOUGHNUTS WITH HONEY
}

\author{
Svetlana Slapšak
}

The contemplation of film history inevitably raises the problem of women's history in an entirely different way than in any other art history. ${ }^{1}$ The same mapping of problems appears, for instance, women as authors and women as motives, but the narrative structuring is quite different. Film has been a part of women's history for over a century, and it has been producing ideas about women's history in a way other arts could not approach at all. The present article tries to search in this direction, not only to detect patterns of thinking about women and to deduce the remnants of narratives (mythical, ritual, ancient), but also to establish some immanent epistemological frameworks that were "responsible" for such thinking. The model is taken from historical anthropology, especially the French school of anthropology of ancient worlds, in which interpretation of images is always argumented within the context of words (texts, names, terms) and most often through semiotic analyses.

Interpreting gender in films with the help of an operational and wellestablished type of methodology originating from ancient studies should be a good starting position for the topic of this volume, which intersects antiquity, gender, and film. In this sense, a cartoon feature (Disney's Snow White and the Seven Dwarfs, 1937) is not a part of the comparison between the two films selected for this study, but an example that serves as a primary model of interpretation. Most of the interpretations that I rely on as epistemological models are based on painted Greek vases, which belong both to contexts of the official use (rituals, sacred spaces, and occasions)

1 Since gender history is occupied primarily with the history of women at the time/ space in which men were holding key positions in the making of history and its narratives, the relation of terms "gender" and "women" shifts in this context toward more logical and less politically correct use, as in Anna Green and Kathleen Troup, eds., The Houses of History: A Critical Reader in Twentieth-Century History and Theory (New York: New York University Press, 1999). 
and to contexts of everyday life (symposium, housware)..$^{2}$ These interpretations clearly show a specific semiotic world in which meanings of words and images are quite different from the stereotypical vision of antiquity. They incite the reflection about diversities of everyday life in any other given historical context, and open possibilities to pass over the limits of convened academic knowledge and to challenge some academics' deep conviction that they can understand the other cultures within a universalizing framework - which is always Eurocentric. Most of all, interpretations of behavior at symposia (images and texts) give an insight into what could be a model of the popular culture in different historical and cultural contexts. The worldwide reception of Disney's Snow White, with all its specificities, is a good example, which on one side excitingly refreshes the old ethnographic debates on polygenesis and paligenesis, and on the other confirms the power of global media and its role in mixing narratives and images. ${ }^{3}$ More importantly, Snow White is bi-dimensional but not illusionist as a film; it is detached from reality by a clearly posited codification. In the words of Lee Artz: ${ }^{4}$

The frame, the shot, the scene, and the sequence that articulate cinematic images by virtue of their composition - characters and actions are highlighted and thus valued by their on screen prominence and positioning. Animation has considerably more representational latitude than non-animated film: image, size, movement, color, lighting, and continuity are easily altered with the stroke of a pen or key.

We cannot but admire the terminological bias here: cartoon is "animated," film is "non-animated," while semantically it should be the other way around. Cinematic images, if they were written more precisely as "kinematic images," would help to "semanticize" the movement, not the historical context of the term "cinema." The "easy alteration" underlined by the author, however, points to a very crucial specificity of the "cartoon": even

2 Cf. François Lissarrague, Un flot d'mages: Une esthétique du banquet grec (Paris: Adam Biro, 1987); Lissarrague, Vases grecs, Les Athéniens et leurs images (Paris: Hazan, 1999); Paul Veyne, François Lissarrague, and Françoise Frontisi-Ducroux, Les mystères du gynecée (Paris: Gallimard, 1998).

${ }^{3}$ See Eric Smoodin, ed., Disney Discourse: Producing The Magic Kingdom (London: Routledge, 1994).

4 Lee Arzt, "Animating Hierarchy: Disney and the Globalization of Capitalism," Global Media Journal 1 (2002), accessed December 2, 2011, http://lass.calumet.purdue.edu/cca/ gmj/fao2/gmj-fao2-artz.htm.

${ }^{5}$ For instance, kinesitherapy, kinesthetic; just like cinematography (cinema), all originate from the Greek kinoumai/kinesis/kinema, but graphems and consequently pronunciations are different. 
if the drawing is repeted so many times, it is still under the total control of the human, and the movement can be represented even without any modern technical assistance (camera, props, projection). Laterna magica and shadow theatre, among other devices, witness of a long tradition of presenting moving/visual/acoustic narratives. All this leads to the most important element of kinematic images, and that is the participation/ intervention of the onlooker. Here I conscientiously bypass the theorizing of the gaze, as I am interested in the question as to which historical anthropological records there are of the participating/intervening gaze (regard intervenant). The difference between a painted vase manipulated by the guests at an ancient symposium, each of them retelling a story or contextualizing it in their own way, and a cartoon feature shown in theatres before a group of people who barely socialize during the show and are unable to intervene or change the narrative, is so great that it does not allow for easy parallels. The frustration before images that demand only emotional reaction and impend the onlooker's intervention and participation in the story-making is sometimes registered in popular culture.

Maybe the best example of such desire of intervention is the cult television series Mystery Science Theater 3ooo, often abbreviated as $M_{3 S} T_{3} K .^{6}$ It is a story about a man and his two robot sidekicks, all trapped on a space station by an evil scientist and forced to watch a selection of bad movies, mostly science-fiction and action movies. The heroes endure the torture by ridiculing movies as they are watching them ("riffing" as a behavior in movie-theatres). They are represented as silhouettes sitting in the rows "before" a TV onlooker during the whole projection. B-rated movies are shown in full length. A discrete visual and a more elaborated and powerful acoustic presence of the regard intervenant (which can be generally located on the screen but never met) "rules" the projection and the TV onlooker, who is deprived of his/her implemented (and in fact false) power: only if he/she takes the position of a double of the critical wit, the superior judge of the worst of the popular culture (as represented by the heroes), including its production modes and distribution of power, can the onlooker identify with the heroes and share the pleasure/salvation.

Most of the public are seriously deprived of critical reading of the popular culture, so this complicated and rather fuzzy way of pointing to the problem is understandable. Furthermore, a sharp distinction between what used to be commonly known as a "cartoon" and the film is now

${ }^{6}$ An American television comedy series created by Joel Hodgson, 1988-1999. 
almost historical: $3_{3} \mathrm{D}$ and other technologies are working hard to erase the distinction, and looking at the backs of some critical elite, learning from them, or aspiring to become them is much harder to imagine than a decade ago. But if Snow White and Mystery Science Theater 3000 are archaeology, belonging to the past of the popular culture, then many of the parallels between the popular cultures in different historical contexts might appear more plausible. Disney's Snow White DVD is a piece of popular culture present in a huge number of comparatevely richer homes with children all over the world, with endless possibilities of interpretations. On the other hand, it has been a topic of research, both as an international fairytale (popular text) and as a cartoon feature. ${ }^{7}$ The status of the cartoon and the status of a painted vase which are manipulated for fun, entertainment, communication, social and cultural confirmation, or "cultural intimacy" do show some similarity, which can be identified as a desire to intervene/participate in the narrative, indicated by images and sounds, but not strictly determined and loosely codified. ${ }^{8}$

But how can Disney's Snow White be "inscribed" into a thematic relation with ancient motives, the reception of antiquity, or even other popular culture products which evoque antiquity? Or, what is "antique" in Disney's Snow White? My point of entry into this thematic area is cult/ ritual, so let us see if the absence of costumes, names, recognizable myths, historical references, and other usual signs of a film dealing with antiquity (e.g., peplos films) can concur with other forms of reception of antiquity. The closest notion of myth that can be functional in this kind of research is Roland Barthes' notion of myth:9 the mythology of Disney's Snow White is the result of many ideological and power inscriptions which have to be mapped, read, and deconstructed - this time in the hope of tracing contents of cult/ritual/ancient.

7 Iring Fetscher, Wer hat Dornröschen wachgeküßt? Das Märchen-Verwirrbuch (Hamburg: Claassen, 1972). This very popular work exemplifies, in a most entertaining way, philosophical schools interpreting fairytales, among them Snow White. See also Jocelyn Steinke, "Cultural Representations of Gender and Science: Portrayals of Female Scientists and Engineers in Popular Films," Science Communication 27 (2005) 27-63; Jill Birnie Henke, "Climbing the 'Great Wall' of Feminism," (paper presented at the Rethinking Disney: Private Control and Public Dimensions Conference, Ft. Lauderdale, FL, November 200o); Henke, Umble Diane Zimmerman, and Nancy J. Smith, "Construction of the Female Self: Feminist Readings of the Disney Heroine," Women's Studies in Communication 19 (1996) 229-49; Keisha L. Hoerner, "Gender Roles in Disney Films: Analyzing Behaviors From Snow White to Simba," Women's Studies in Communication 19 (1996) 213-28.

8 Term invented by Michael Herzfeld in Cultural Intimacy: Social Poetics in the NationState (London: Routledge, 1996).

${ }^{9}$ Roland Barthes, Mythologies (Paris: Editions du Seuil, 1957). 
Film does not belong to the "receptional site-catchement" of antiquity: we cannot speak of any continuity of beliefs or behaviors from ancient rituals contained in film presentations, except for the extremely rare films made by artists close to scientific interpretations, ${ }^{10}$ but more of randomly revived narratives (often fragmented, sometimes altered beyond recognition), which are all part of phantasms provoked by and produced for needs initiated in social-cultural contexts in the time-span of one century, all over the planet. So what does "ancient+ritual" mean in the production of phantasms in film? Without grasping for the collective unconscious, a very basic thesaurus of knowledge of ancient/classical can be imagined, responding to the professonal and general education of Disney's illustrators and of Disney himself. At the time of creation of the Snow White, the praise of "classical" (beauty, order, harmony, whiteness) was certainly heavily present in the state decorum and consequently in the media and popular culture in at least two European countries - Germany and Italy. Hints at Disney's sympathies for the Nazi regimes are a kind of commonplace in his biographies. ${ }^{11}$ The Alpine style of dwarfs' dwelling could indicate the original setting of the European fairytale, while a pro-German feeling does seem like too much of a stretch. Negative labelling could be more indicative if we think of the evil queen stepmother: she lives in the castle in which her laboratory, the place of her work, evil science/magic, is at the bottom (vertical division of power, university inside the city), while the dwarfs' "campus," including the typical mess of the American students' dwelling, has a horizontal (democratic) space-power distribution. Is this a contrast between European and American intellectual life and academic lifestyle? The existing/expected religious horizon of North America has been communicating with many other religion-marked cultures all over the world, through the immigration and the media expansion. The possible answer could be that the Disney's Snow White is based not on recognizable big religious narratives but on presumably fragmented cult and ritual narative sequences - and the polytheistic system could be the best choice of narrative patterns in this case.

10 Such exceptional cases would be Pier-Paolo Pasolinis's films inspired by ancient drama - Edipo Re (1967) and Medea (1969): in Edipo Re, Pasolini confronts Freud's interpretation and the "ritual,: non-European one, which is surprisingly close to Jean-Pierre Vernant' anti-psychoanalytical approach, and that of his followers, like Page du Bois. Also, see in this volume, p. 213-27.

11 Marc Eliot, Walt Disney: Hollywood's Dark Prince (Secaucus NJ: Carol Publishing Corporation, 1993). 
We come to the question of gender, how it is conceptualized and related to presumably ancient cult and ritual in Disney's Snow White. The role of women in film history puts forth questions about the forms of the historical narrative, about the relation of film and its social context, and about dominant discourses that are reproduced in films (based on the Barthesian concept of mythology). Without any doubt, the main problem or the "oversignifiers" of all these questions are the subordination and inequality to which women and other gender varieties except the white male have been exposed in a vast majority of feature-film productions since the very beginning of the film history. In other words, film has been a powerful tool of gender repression, and in many ways it quickly recuperated many forgotten forms of male domination, just in the midst of a period of one of the most successful actions feminists ever realized - the movement for the right of vote. On the other hand, film radically changed the politics of desire, favoring the female figure: the feminine visual presence in a new world of images and information during and after the World War I, the enhancing and inspiring mirror of fashion, new mobility of the body, new spaces, a new speed (vehicles, camera moves), then later a new acoustic identity, an entirely new temporality to explore - all of these emancipatory innovations were beneficiary to women. Film has proven to be one of the most powerful weapons of ideology, in fact multiple new ideologies of the twentieth century. One reason for this lies in its pertinent work on the mechanisms of identification, most of which can be recognized as the most rudimentary levels of psychic identity and the drives - collective conscious under its many names and psychoanalytical schools' assignments. The illusion of reality created by film does not postulate complicated frameworks of knowledge to be accepted. The works, unlike in other arts, are hardly detectable, due to the special status of "reality" acquired previously by photography, before film had been invented. The personal effort to understand is not privileged; it is the empathy of the majority in the movie theater that forces the massive familiarizing with the film rhetoric and poetics. All of this is, as I tried to show above, different in the cartoon, but the question is if the gender perspective changes at all between feature film and feature-length cartoon. Narratives and character building became quite close thanks to Disney's innovation with Snow White. Furthermore, Snow White marked a serious retrograde shift in the full blooming of a characteristic Hollywood film genre, a screwball comedy with a strong, unpredictable, slightly crazy female character, played by actresses like Claudette Colbert, Carol Lombard, and above all Katharine Hepburn. Snow White certainly had a backlash effect. In fact, it would 
have been almost unimaginable to present such a heroine in a feature film in the late 1930s, even in a feature film targeting children.

Being gender-repressive in its performing, film became a disappointing means of artistic expression very early in its history, and it needed both enthusiastic individual artists, ready to experiment with a popular form of art, and a clear distinction between popular and artistic film production. Feminist theory has focused on questions of an individual's identity as female or male, and how these gender differences might lie at the core of processes of subordination, power, and inequality. And their mostly pessimistic conclusions have prevailed until today. Does this repeat somehow the early disappointment of artists and intellectuals in contact with film?

Using the anthropological framework of the school of thought I have chosen, I would argue that different social and cultural contexts have been producing successful ideological products that do not postulate the sado-makeover of the gaze or satisfy only the male desire. In film production in socialist countries (Soviet Russian, Eastern European, Albanian, Yugoslav, Chinese, North-Korean), the female body obtains the highest ideological connotation, becoming, in its obvious and often naive differences regarding the Western-capitalist bodies, the main visual symbol of the difference and change in social order. This does create some disorder in the male desire that it seeks to challenge and change. The argument of the dominant sexual fantasy and most of the psychoanalytical arguments do not fit into this ideological invention. It might have been rather shortlived in the history of these cinematographies as they started producing more gender-stereotyped films in order to seduce the Western public and critics and as women's position started to deteriorate because of the recovering patriarchal rule. The emancipatory image of women appeared even outside of the socialist world in the Italian neo-realist cinema, but their tragic objectivization in the war-torn and unjust society produced the opposite of the female power fantasy of the socialist films.

If cinema has power to construct in uniting fantasy with documentary authenticity in an immediacy which gives an illusion of reality, then an image of a powerful woman at the wheel of a tractor humiliating men and not punished but celebrated by the ruling discourse cannot be read quite easily in the Laura Mulvey interpretation key. ${ }^{12}$ She says that ideology refers to the ideas and beliefs through which we make sense of our lived experience, which can serve to conceal the conditions and contradictions

12 Laura Mulvey, Visual and Other Pleasures (Bloomington: Indiana University Press, 1987). 
underlying that experience. This way of defining ideology falls short in explaining how narratives work and who is inventing them. Therefore it should be enlarged by Roland Barthes' notion of mythologies as social inventions of signs that correspond to class or other collective representation and can be easily developed from simple conversation patterns to complicated narratives. Ideology might be perpetuated through the processes by which subjectivity is culturally constructed; gendered subjectivity can be seen as constituted ideologically, ensuring the continual reproduction of dominant masculinity and dominated femininity - but with some breaks, pauses, and even reversals occurring occasionally. I intend to work in such a fracture and make it visible by comparison with an example of extreme dominant/dominated gender film product: both are using ancient mythologies in the Barthesian sense in order to present gender-related narratives.

Should the attraction of ancient topics in film making be compared to the attraction of ancient texts and images for the internet? Only two decades after the internet was created many of the ancient texts in Greek and Latin are available to all, and also images, lexicons, philological handbooks and the like, including many periodicals. An initial explanation is simple - all of these are free for use with no authorship and royalties to be respected or paid. Nothing could be more misleading: the correct use of ancient topics in film, although it is all free, is unacceptable for the film industry's branch of script writing. Since the author cannot be consulted, and specialists are not included as a rule, ancient plots are massacred, with a very few cases in which the original text can be recognized. There are no good reasons in the economy of words here: so many very verbal films have been produced, and there are many effective ways of combining words and images in presenting monologues and dialogues in ways impossible in theater. Moreover, there is a rich literature of diversified interpretations of ancient texts, which could inspire filmmakers. But still, from peplum movies to Xena: Warrior Princess, antiquity has been relentlessly distorted, falsified, and mashed into unimaginable combinations. "Why" here would be an eccentric question, because the answer is banal. Therefore the challenge for a researcher lies also in finding fractured, fragmented, nonplanned bits and pieces of reception of antiquity that might have become something like a standard cultural "luggage" in everyday life. The critical reading of films, focused on antiquity and gender, could reveal some of the processes of melting down knowledge into mythologies - again in the Barthesian sense - which then could be designed into ideological patterns for use in the mass media culture and politics. This kind of critical reading 
could actually help feminist theory of film, which rightly condemns film reduction of the image of woman to a limited range of female stereotypes, but detailed analyses have not yet generated sufficient knowledge or theoretical tools to adequately explain these processes at work in a film narrative or how women interpret and respond to film representations.

The dominant discourse has naturalized the masculine as universal. Feminist thinkers were the first to point to sexual identities and relations as social-cultural constructions and not natural givens. The object of such study is rendered as necessary and legitimate as a study of an aesthetic or social dimension of work of art, and all the more so since the sexual dimension of cultural productions is regarded as a universal given. This position can be easily related to the next epistemological level, to a specific position of the anthropology of ancient worlds, a discipline that in many ways deconstructs the narratives of "natural givens" and the "masculine as universal," even if there is no visible connection with feminist thinking. A good example is Marcel Detienne's seminal structuralist study on "Adonis' gardens." ${ }^{13}$ Without being a feminist, Detienne has perfectly decoded this festivity as the ironic women's celebration of the male's short-lived sexual capacities and thus discovered an important aspect of women's everyday lives as well as narratives in Athens in the fourth century BC and later. In reading ancient women's cults and rituals using this example, a semiotic framework of irony and subversion is certainly expanding our understanding of ancient women.

Knowledge about women, ranging from the stereotypes of public discourse, through scientific factual developments of natural sciences, all the way to feminist epistemology, depends on the discourse of culture at the local, intercultural, and global levels. But the scientifically formulated knowledge or theoretical discourse, in this case feminist epistemology, seldom or slowly influences public discourse and political rhetoric. By contrast, public discourse and political rhetoric, the latter also including, in the majority of societies, the privileged rhetoric of culture, can in many ways and rather rapidly and permanently influence the academic context in which feminist epistemology tries to inscribe itself, but also the very feminist academic environment. The academic environment, whether it produces hegemonic discourse or just displays habits of an "old boys' club," is bound to take action against feminist epistemology: it represents

13 Marcel Detienne, Les Jardins d'Adonis: la mythologie des aromates en Grèce (Paris: Gallimard, 1972); English: Janet Lloyd, trans., The Gardens of Adonis: Spices in Greek Mythology (Princeton: Princeton University Press, 1994). 
critical intervention which, by its very definition, threatens conservative epistemic systems. All knowledge is power, real power, and is in a Foucaultian sense, "evil." Feminist epistemology has an advantage which is, within women's and gender studies in general, frequently experienced as a split: it is an activism, which should, in fact, serve as a basis for correction, as a principal surveillance device against hermeneutic violence, but against malice too. Thus the critique of mentality, combined with activism, is a necessary part of preparatory actions for the construction of knowledge, which should be focused on research of the production of stereotypes of women. Among these sources, film is, along with literature and, later, television, the most representative.

But how we can construct our epistemological toolbox in the case of ancient women's cults and rituals when appropriated by a popular cultural production of film? My choice of Snow White for such an analysis is obvious. Having a different relation with the reality and creating a very specific naturalization, the cartoon feature immediately relates with folklore and oral cultural production, with symbolic presentations, but also with the popular culture. The largest possible reception is secured by the genre of fairy tale and by the encrypted patriarchal narrative. It is indeed very easy to insert additional ideological signifiers, which, whatever the context might be, reproduce the globally desired model of a young woman. For Walt Disney, these additional ideological signifiers were American colonizing patriotism and more or less conservative political perspectives. The presumed enemies of such an ideological setting are educated mature women and European liberalism.

In order to create such an imaginary world, Disney had to work on the European versions of the fairy tale: first, Snow White's mother is excluded from the causality of the story; then, the difference between the European and the American site of the production of knowledge is established. The castle, the evil stepmother's domain, is vertically/hierarchically divided space, and the power-to-knowledge downsloping line is clear. This is, as I already indicated, the European university in the city. In the case of dwarfs' house, far away from the castle-city, it is an American campus, along with the laboratory-mine. The producers of knowledge are a collective of weird male figures, a bunch of sympathetic old boys, sexually depraved, but good humored - a cultural, particularly film stereotype of the American academic before Who's Afraid of Virginia Woolf? (1966). The dwarfs' house is a typical disorderly fraternity house on campus before the coming of the pioneer woman, that is, Snow White. The ideological desire of "order" in academia is quite clear. Through the pioneer woman's inter- 
vention, the dwelling is restored in its Alpine (Bavarian? Tyrolian? Swiss?) kitsch glory, with the corresponding yodeling acoustic identification.

The setting is established. Enter Snow White, who had to be reconstructed according to the ideological intervention. She has to undergo a rite de passage through death in order to reappear as a new world heroine. Her terrifying travel through the underworld is not real in the cartoon world (everything is a product of her fear), but the consequences are. Snow White symbolically awakens in America, after her life has been threatened in a European-looking castle. The new location is illustrated by the animals that start surrounding her, among them raccoons, chipmunks, and blue jays, which cannot be seen in Europe. ${ }^{14}$ But this clear distinction of the animal order had to rely on a certain narrative, familiar in many cultures. Therefore, rites de passage taken from myths of Dionysus, Artemis, and Persephone are mixed.

We might suspect that all this was done only to introduce cute fluffy cartoon animals, but they inevitably bear some unplanned, or carefully deliberate, meanings. Animals surrounding and helping Snow White, while she demonstrates her love for them (including the motherly attitude and a presumed capacity of reproduction) give a perfect picture of a pompe of Artemis, or Dionysus. Snow White as potnia theron does not carry a bow and arrows like Artemis when she is surrounded by animals on Greek vases to denote her power over life, reproduction, and death. Snow White is a docile object of the patriarchal rule. She has just undergone symbolic death, which makes her half human, half goddess.

Her ambivalent position allows her to play both roles of a mother and of a work supervisor/educator regulating the dwarfs' behavior, although she is a virgin. This "advertizing" of patriarchal feminine qualities before spectators that do not have any ambition or social competence to take part in the mating procedures clearly indicates the ritual aspect of Snow White's behavior, a performative urge to do things related to a cult. Dionysus' pompe comes immediately to mind not only in the scene in which Snow White is dragged by animals toward her new home, or sleeps there with them, but also in the scene in which the dwarfs, just like the ancient pygmies, fight with the animals - and Dionysus is certainly a good mythological parallel for surviving death. The case for Persephone is blurred by the imperative absence of a mother, or any other relation with older women and mature womanhood: Snow White must be totally cut off and

14 Raccoons were introduced into Europe and Asia mostly in the second half of the twentieth century, and into the USSR in the late 1930 . 
constructed as an exclusive male product. Thus comes the American, resurrected Snow White, who is willing to distribute her pioneer woman's and mother's qualities and authority and to pass the exam before the sexually irrelevant academic dwarfs, in order to later offer her services in the right patriarchal setting. Snow White/Artemis executes her virgin/motherto-be/goddess' power on dwarfs through possession of their names, purifying, disciplining, partially desexualizing, and introducing civic rules and regulative practices. To get to the right patriarchal setting, she has to die again, breaking all remaining links with her gender group, and then to awake by the intervention of the only legitimate owner of her fertility and work capacities.

Once she has been kissed by Prince Charming, Snow White does not walk any more, she is carried around by her new master, the prince, as a true object of his desire and his control over her. They reach his castle, which blends with the sun in the final scene of the cartoon. The male sun god takes over the story. "Lifting up" is a usual procedure of censoring the rape: verbally, it is censored since antiquity and in the most of the European languages by the use of the meaning rape-kidnapping, and by the visual presentation of lifting up instead of putting down, which is the real action of rape..$^{15}$

The evil stepmother provides a good example of a reading of a masked, hidden, and perverted ideological reconstruction. She appears as a quotation of Hollywood vamps: almost everything of the body is covered, and the seductress works mostly with her words, combined with body artistry and the signs of power supporting the rhetoric. When she moves into her downstairs academic domain, the queen works as a devoted scientist: experiment, verification, choice of literature, checking the sources, double-checking the footnotes. Her transformation into an old hag is a horrifying perspective of the uselessness and danger of the female climax women should preferably die before. But she is so evil that she does not die, and continues in performing a grotesquely perverted relation with a girl, who does not want any of women's knowledge nor any truth about women's life. Since Snow White refuses to be Eve, the apple must kill her. A lynching party is the only social solution for a witch. There is little or nothing here to be related to ancient myths or rituals; in order to profile Snow White as a goddess, the stepmother has to be constructed as a negation of every possible use of myths and rituals, according to the

15 See Susan Deacy and Karen F. Pierce, eds., Rape in Antiquity: Sexual Violence in the Greek and Roman Worlds, (London: Duckworth Publishers, 2002). 
censorship process already done in the fairy tale, through which Snow White had to be separated from the collective of women. She is deprived of the status of Demeter, or Artemis' mother, or Dionysus' maenads. The figure of the goddess of nature and the ruler of animals is used to present the pioneering, new, innocent but powerful new world, in the contrast with the old, corrupted Europe. The figure of the evil queen is an expected patriarchal closure, which should also bee seen in the context of the Hollywood production of the 1920s and 1930s. After two decades of mostly European vamps and independent heroines, often rich but socially aware, silly but persistent in the quest of women's rights, witty and chattering, invented to sooth the problems of the male population during the great economic crisis - thus figures of an emerging anticapitalist set of mind - there comes Disney's political backlash: an ignorant virgin offering her services, completely cut off from the society of women, denying their knowledge and experience, and ready to lose her mobility and serve the master of the house after she proved she can control children and sexuality in the episode with the dwarfs. But this virgin is endowed with the great symbolic meaning of American patriotism.

There are even more convincing uses of rituals and images that situate the cartoon in the space of ancient references, as in the case of the virginal taboo. In the opening of the movie, Snow White appears as a virgin in rags (according to Barthes, holes and cuts in garments are sexier than a nude body), but powerful enough to instigate a prince's (any male's) fear of virginal gaze. Therefore, the first exchanged gazes by Snow White and the Prince must be filtered through a neutralizing mirror, in this instance a well's water surface. The acoustic identification (the echo) is followed by the visual one (see Figure 1).

The practice is analogous with the ritual practices around Medusa (the evil eye). On Greek vases, Perseus and Athena look at the head of Medusa on a water surface, and thus reinforce their own alliance; or Perseus looks at Medusa's severed head reflected on the shield while Athena looks directly at the head. As Jean-Pierre Vernant and Françoise Frontisi-Ducroux put it, "in the eye of the mirror." ${ }^{16}$ The use of a standard fairy-tale virginal blushing goes into a dark taboo, because it is there, just slightly covered, and then exposed by the strong visual rendering of the cartoon. This is crucial

\footnotetext{
16 Jean-Pierre Vernant and Françoise Frontisi-Ducroux, Dans l'oeil du miroir (Paris: Editions Odile Jacob, 1997); Françoise Frontisi-Ducroux, "Andromède et la naissance du corail," in Stella Georgoudi and Jean-Pierre Vernant, eds., Mythes grecs au figuré: de l'antiquité au baroque (Paris: Gallimard, 1996) 135-165.
} 


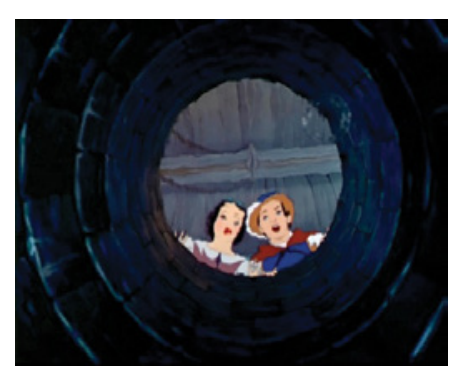

Figure 1

for the reading of the Snow White. It should be read within the same interpretation framework set up by the French anthropological school for the Greek vases and other visual material. The mirror plays an important part in the film's plot, from the mask in the mirror, to the diamonds and mineral surfaces (dwarfs' mine), to the purifying water for the dwarfs and soap bubbles. In Disney's Cinderella, the girl is working (washing the staircase) and singing, and bubbles echo her singing visually (multiplying her figure) and acoustically (as a quire). In fact, mirror in animation shows many more visual capacities and ways of interpretation than any mirror in a film.

We could speculate on who in Disney's large team was familiar with ancient Greek mythology, or how ancient myths are built in the massculture narratives on a global scale, both in colonizing and in colonized cultures. It should suffice to underline that this type of investigation, as attractive as it may be, is of no bearing to the need to reflect critically on non-said and non-seen, hidden, or masked narratives of the patriarchal construct of the feminine.

The global acceptance of the cartoon feature Snow White and the Seven Dwarves clouds its historical and contextual role in the American and American-influenced popular cultures, which is a patriarchal comeback with a vengeance, a clear attempt to diminish the ruling figure of a new, independent woman. Ancient cults and rituals are used to denote the universal (polytheistic) cultural space beneath the narratives of great religions, to give it qualities that form a new feminine model, and to distance this new feminine model from women's history - even the stereotypical one. The new feminine model also evokes American patriotism and colonialism, which are inevitable in making the final conservative patriarchal gender figure. Thus Disney's Snow White presents a perfect example of possible uses of ancient cult and ritual narratives, but also a perfect object 
of manipulation of narratives and images in cultural practice, showing many common anthropological features similar to the ancient manipulation with narratives and images on Greek vases.

Loukoumades me meli (Doughnuts with Honey) by Olga Malea (Greece, 2005) is an example of quite the opposite, a feature film in which there is a clear link between ancient images and texts and the film itself. Olga Malea is a rare type of woman director who is oriented towards comedy. ${ }^{17}$ In fact, the author explores different ways of interpretation and subversion of some myths and rituals and plays freely with the quotations and hints at the original. Loukoumades me meli is a crazy comedy, which integrates a number of ancient women's cults and rituals and is structurally related to ancient texts, in this instance the comedies of Aristophanes. ${ }^{18}$ The plot is "Aristophanic" in the sense that the world is turned upside-down. ${ }^{19}$ It is not a comedy of characters but a satire on the political texture of today's world. ${ }^{20}$

A young man who is suffering from financial and sexual shortcomings leaves Athens, his job as a pastry-maker, and his unsatisfied lovers, tries (unsuccessfully) to sneak out of his unpaid flat, and eventually goes to seek help from his loving aunt in the province, where he had been raised by her. Trying to provoke his sexual fantasy for one last time, his lover covers her body with loukoumades and honey, causing him to flip. She chases him from her flat. Apparently, his sexual inadequacy has something to do with the sweet he has to create in the pastry shop, loukoumades, fried doughnuts served with nuts and honey.

The young hero is an outcast, like several of Aristophanes' lonely antiheroes in The Acharnians, Birds, Peace and Plutus. His only way to come back to his co-citizens' collective is to change radically the collective - to make it accept the peace or compromise with a new power, and eventually to deny the earlier pressure of the majority. This same role in Aristophanes' comedies is played by a lonely hero or by the other collective of non-citizens, the women. The hero has to depart, to leave the space of the

17 Persephone Tselentis Apostolidis, "Female Presence and Male Absence: Recent Films by Greek Women," Film Criticism 27 (2002) 43-58; the author defines Maleas' film Risotto (2001) as "commercial feminist."

18 See A.M. Bowie, Aristophanes: Myth, Ritual and Comedy, (Cambridge: Cambridge University Press, 1996).

19 Paul Cartlege, Aristophanes And His Theatre of the Absurd (London: Duckworth Publishers, 2007).

20 M.S. Silk, Aristophanes and the Definition of Comedy (Oxford: Oxford University Press, 2002). 
Athenian democracy, to evacuate and separate himself or themselves, be it to Acropolis, to his own home and backyard (voluntarily or as a confinement), to another world or underworld, to the basket hanging from the ceiling, and so on. Temporary evacuation/displacement is crucial to all of Aristophanes' comic plots.

Maleas' hero comes to the Peloponnesian village and finds two feminine helpers there - his aunt, married to the mayor of the village, and his former school sweetheart, Phenia. Dikaiopolis, the hero of Aristophanes' Acharnians, also has two feminine helpers, his wife and his daughter. The aunt, overweight and clearly miserable in her marriage, has a pet pig which adores sweets. Phenia works for a local funeral parlor, dresses like a darker, smokes pot, and is still interested in her early flame, as she is in any young man around. There is an obvious conflict between the hero and his aunt's husband, the mayor, who is luring young boys with loukoumades to get their sexual favors. Recognizing the pedophile predator, the young hero trains the pig Marika to track down loukoumades and thus to prevent mayor's exploits. A sudden death of one of the twin sisters (heart attack as a consequence of the love declaration by the funeral parlor's owner), the main pastry-makers in the village, launches the crazy chain of events: the funeral is postponed due to a mayhem caused by Phenia, who drives the funeral car and chases the pig at the same time; the mayor is desperately trying to convince the other twin to make loukoumades for him because the plot with the tracking pig succeeded and left him without his prey; Phenia is seducing the sister's virgin son in the funeral parlor; a sleeping potion, used to pacify distressed relatives, is sprinkled over the loukoumades offered to the dead pastry-maker; and the pig falls asleep over the dead woman, only to wake up at the moment of lowering the casket into the grave. The funeral is postponed again; a wandering diet specialist falls in love with the aunt; the pig is almost sacrificed by the angry funeral mob; eventually, the young hero manages to reveal the mayor's pedophilia to the collective of the citizens with the help of the aunt; and he also reveals that he had been seduced by loukoumades and sexually abused by the mayor as a child. The mayor is arrested, the aunt is free to love and be loved again, and the young hero makes love with Phenia on a bed of loukoumades in a pastry-shop.

Food, sex, and death, the three main anthropological components of Aristophanes' comedies, had to be deregulated so the comedy could start. Food has to be abundant, genders have to be destabilized, death has to be ridiculed. Therefore, mentioning food, obscenities, and black humor are the crucial elements of the Aristophanic discourse. Olga Malea structures 
her comedy around these thematic axes, which overlap persistently: food has a strong visual presence in the film (a snorkel camera is used for the details of making loukoumades). It is an important part of sexual habits of all kinds (as attraction, lure, as a necessary compliment to the sex). There is women's obesity, which becomes sexually attractive. Food also appears as the main substance in funerary ritual. Making food is "sexed" along with food consumption. The final scene of the film, making love on the food, suggests the mixture of body and food, both interconsuming, and both eventually consumed by death.

With this insistence on the standard Aristophanic finale eat/drink/sex, Malea draws an important line in the reception of Aristophanes, which is rather poor compared to the reception of the authors of tragedies. I have seen over the years a number of European theatre versions of Aristophanes' plays, most of them in Greece. The majority of these stagings have had a serious problem with the finale, which clashes with dramatic rules (coming from noncontextual interpretations of Aristotle's Poetics), the rationality of the usual comic plot, and surely the restrictions and taboos remaining from Christian moral traditions. All of these problems are postAristophanic, but they work and collide with the arbitrary or the apparent loss of sense in Aristophanes' comedies. I still remember Aristophanes' Birds in the Burgtheater in Vienna which, instead of the crazy party, had had a completely new mimic finale: a small girl enters the scene, wearing a hat and carrying a bird. ${ }^{21}$ She pulls a needle from her hat and pierces the bird. Violence, death and awe had to replace a happy carnival feeling. Why? Was the absence of a heavy meaning and a pessimistic message at the end so troubling? The answer might be that Aristophanes' party-finale made sense in the Athenian democracy, orienting citizens - almost all of them, because they participated in the theater as one of the important institutions of democracy - toward refocusing on the serious political work. Comedy, beside being a ritual due to Dionysus, was dealing with highly imaginary concepts and things: women and slaves having political power, phantasmic beings, an absurd and topsy-turvy world. In the modern Western theater, which is a cultural commodity and a social space of the elite, the link between the democracy and the theater public has almost totally disappeared, only vaguely and not so often re-established in the so called "political theater." Citizens leave the theater not to resume their political roles the next day, recognizing the same faces in the parliament,

21 Director Luca Ronconi, 1975. 
but never to meet again - except for another theater performance. Instead of practicing democracy, they are oriented to reflect on problems individually.

By respecting the spirit of the Aristophanes' standard comedy finale in the film, which is not socially defined by the elite (and the theater), Olga Malea in fact rethinks democracy. The main representative of the power, the mayor, is publicly unmasked, ridiculed, and humiliated, just as in Aristophanes' comedies. The anti-hero is victorious. Food and sex triumph over death. This reception of the ancient Athenian's comedy is marked by an outspoken generalized ambition, and conceptualizes his work as a whole, as a political-cultural invention worthy of actualization. Malea's fine and detailed web of motives, images, topics, and stylistic reworking of Aristophanic comedy is inserted into the big picture. As a public, we have grown enough to understand Aristophanes, we are mature enough to deal with him. The usual cultural stereotype about him, that he is way too archaic, too contextual, too specific and untranslatable, is in fact put upside-down. It is the public who could not understand Aristophanes because he is too advanced, too clever, too funny, too corrosive for the institutions, too dangerous for enslaved and hypocrites. Other films by Olga Malea confirm this authentic and passionate reading of Aristophanes. Her films about feminine sexuality,22 her film on democracy and minority (Godfather for the First Time [Protifora nonos], 2007) thematized as a children's film, all invoke Aristophanes' topics, style, and a bold mixture of absurd humor, sarcasm, and wordplay. ${ }^{23}$

As in the majority of Aristophanes' extant comedies, the central plot in Olga Malea's Doughnuts with Honey is about emancipation, usually of an "impossible" individual or group, impossible in the sense of citizen's identity. ${ }^{24}$ Aristophanes' staged heroes are women, or citizens excluded from the democratic body of citizens, or gods that behave differently (Dionysus, Heracles). Malea's hero is "excluded" from the body of other citizens by his sexual incapacity, therefore he has to leave and re-establish his citizen's

22 The Cow's Orgasm, (1996), The Mating Game (1998), Risotto, (2001).

23 One of the rare film theory and history authors who often refers to Aristophanes is Andrew Horton, especially in Laughing Out Loud: Writing the Comedy-Centered Screenplay (Berkeley: University of California Press, 2000).

${ }^{24}$ In my reading of Aristophanes' comedies I rely very much on interpretations by Mladen and Dubravko Škiljan (father and son), Croatian academics, editors and translators of Aristophanes. Mladen Škiljan, who used to be a theater director, combined Mikhail Bakhtin's theory and research on the "culture of laughing" and modern theorizing of the performative. But, Slavica non leguntur... see Svetlana Slapšak, "Aristofan i dva Škiljana", Monitor ISH 11 (2009) 71-83. 
identity. The village is a weird place, both a utopia with strange creatures (Birds) and the underworld, the reign of death (Frogs). The hero has to deconstruct the ruling order, as in these two Aristophanic comedies, and then re-establish himself.

Then there are the details. For instance, the pig is a linguistic sign of the feminine sexuality. Choiros in ancient Greek means both "pig" and "vulva." One of the most obscene scenes in all of Aristophanes' comedies (The Acharnians 740-835) is about two girls posing as pigs in order to be traded for food. Piglets were sacrificed to Demeter during the Eleusinian Mysteries. Here in the film, to save a pig from the angry mob, the hero cuts his own hand and lets the blood flow, so he effectuates the sacrificial ritual. The Hellenistic figure of Baubo is sometimes represented as a naked women spreading her legs wide apart, revealing a pig. ${ }^{25}$ In the film, Phenia always wears provocative black clothes (or very little clothing), uses drugs to make people sleep, wants to make love on the grave, rides a funeral car - there are too many signs not to recognize her as a comic Persephone. There is an ambulant specialist in dieting who makes women eat and trains them in the forest; it is hard not to see him as a parodic Dionysus. This is why I am not making a point of one or two scenes: the whole film is constructed as an Aristophanic comedy, with all the relevant cult/ritual allusions which are meant to make it funnier. The feminine ritual triangle of Demeter-Persephone-pig/sacrifice is followed by the deconstruction of death rituals and the ritual triangle of death-womenlaughter. ${ }^{26}$ The arbitrary ritual differences are ironized in the scene in which Pakistani guest-workers notice the sleeping pig inside the casket as they are closing the lid, and comment that "these Christians" have weird funerary rituals. Around the young hero (or rather the antihero), there is a whole array of heroines, some with a goddess' appeal - Phenia, the loving aunt, the twin sisters, the unsatisfied nymph in Athens, and, of course, a female pig. The masculine counterpart is less impressive. Beside the pedophile mayor, the diet-maker and the funeral parlor owner are the only comic representatives.

When I started to look for the presentation of women's cults and rituals in film, I decided to prefer Motive (in the sense of Elisabeth Frenzel's

\footnotetext{
25 Svetlana Slapšak, "Baubo: slika iz arheologije misoginije," ProFemina 10 (2004) 15-22.

${ }^{26}$ See Lada Stevanović, Laughing at the Funeral: Gender and Anthropology in Greek Funerary Rites (Beograd: Etnografski Institut, 2009).
} 
division) to Stoffe. ${ }^{27}$ By doing so I saved myself from analyzing, for instance, a star-packed film on the fall of Troy, in which llamas are merrily trampling through the city market. I wanted to see if film can be creative and functional in visualizing ancient behavior and beliefs and if it can propose difference and diversity as starting points of interest and curiosity for today's public without using "ancient" apparel. In a way, my question was whether film and television can compare to the unlimited narrative possibilities that were opened just by manipulating an ancient painted vase. The answer was yes: the screen/box and the vase are comparable in inciting new stories, even if they are not comparable in the amount of the ancient onlooker's freedom and direct impact on the story. The modern onlooker is much more limited in his participation.

In Disney's Snow White, ancient women's cult is used to translate an ideological message concerning the state of affairs between Europe and the United States. In the case of Olga Malea's Doughnuts with Honey, a successful revival of a performative genre from antiquity contains parodic renderings of ancient women's cults and rituals which are not manipulated into an ideological message, but rather used, because they are recognizable, to send a clear political and feminist message. There is no doubt that in the first case a superficial knowledge of antiquity is displayed, something like a high school command of information, which is inevitably behind new discoveries and interpretations. In the case of Olga Malea's film(s), a in-depth reading of one ancient author is applied. The chosen author, Aristophanes, has been notoriously marked by controversial readings and interpretations in the academic population (labeled both as conservative and proto-communist), and with a desperately modest reception. Malea undertakes a difficult job to reconstruct Aristophanes' original laughtermaking machine and search for answers about the poor reception. Her indirect answer is that a lack of democratic procedures (which inevitably includes women's participation and equality) made Aristophanes' comedies difficult to understand and enjoy in cultures deprived of direct democracy. Thus a possible resetting for an Aristophanic plot could be a small community in which politics are condensed in human relations among people who intimately know each other, ${ }^{28}$ so no big deceit is pos-

27 Elisabeth Frenzel, Stoffe der Weltliteratur: Ein Lexikon dichtungsgeschichtlicher Längsschnitte (Stuttgart: Kröner, 1962); Motive der Weltliteratur. Ein Lexikon dichtungsgeschichtlicher Längsschnitte (Stuttgart: Kröner, 1976).

28 This might be very close to the anthopological situation analysed by Herzfeld in his notion of cultural intimacy, based on Greek examples; Cultural Intimacy. 
sible, but rather adjustments to the community's needs and expectations, including a revelation of the perversion on the highest political level. This, however, can be done only by an outcast. Olga Malea's immanent poetics consist of a tapestry-base of ritual continuity (women's cults and rituals), which can still enhance subversion of social-cultural patriarchal rules and on which a new reading of Aristophanes is interwoven. Irony and subversion provide for the total lack of any nationalist "Hellenic" notion of glorious continuity. This feminist revision of Aristophanes' unlimited criticism of any form of power revives not only cultural and political energy but also women's practices and carnivalesque fun of some modern Adonia.

\section{Works Cited}

Barthes, Roland. Mythologies (Paris: Editions du Seuil, 1957).

Bowie, A.M. Aristophanes: Myth, Ritual and Comedy, (Cambridge: Cambridge University Press, 1996).

Cartlege, Paul. Aristophanes And His Theatre of the Absurd (London: Duckworth Publishers, 2007).

Deacy, Susan and Karen F. Pierce, eds. Rape in Antiquity: Sexual Violence in the Greek and Roman Worlds (London: Duckworth Publishers, 2002).

Detienne, Marcel. Les Jardins d'Adonis: la mythologie des aromates en Grèce (Paris: Gallimard, 1972) English: Janet Lloyd, trans., The Gardens of Adonis: Spices in Greek Mythology (Princeton: Princeton University Press, 1994).

Eliot, Marc. Walt Disney: Hollywood's Dark Prince (Secaucus NJ: Carol Publishing Corporation, 1993).

Fetscher, Iring. Wer hat Dornröschen wachgeküßt? Das Märchen-Verwirrbuch (Hamburg: Claassen, 1972).

Frenzel, Elisabeth. Stoffe der Weltliteratur: Ein Lexikon dichtungsgeschichtlicher Längsschnitte (Stuttgart: Kröner, 1962).

—. Motive der Weltliteratur. Ein Lexikon dichtungsgeschichtlicher Längsschnitte (Stuttgart: Kröner, 1976).

Frontisi-Ducroux, Françoise. "Andromède et la naissance du corail," in Stella Georgoudi and Jean-Pierre Vernant, eds., Mythes grecs au figuré: de l'antiquité au baroque (Paris: Gallimard, 1996) 135-165.

Green, Anna and Kathleen Troup, eds. The Houses of History: A Critical Reader in TwentiethCentury History and Theory (New York: New York University Press, 1999).

Henke, Jill Birnie. "Climbing the 'Great Wall' of Feminism," (paper presented at the Rethinking Disney: Private Control and Public Dimensions Conference, Ft. Lauderdale, FL, November, 2000).

Henke, Jill Birnie, Umble Diane Zimmerman, and Nancy J. Smith. "Construction of the Female Self: Feminist Readings of the Disney Heroine," Women's Studies in Communication 19 (1996) 229-49.

Herzfeld, Michael. Cultural Intimacy: The Poetics of the Nation-State (London: Routledge, 1996).

Hoerner, Keisha L. "Gender Roles in Disney Films: Analyzing Behaviors From Snow White to Simba," Women's Studies in Communication 19 (1996) 213-28.

Horton, Andrew. Laughing Out Loud: Writing the Comedy-Centered Screenplay (Berkeley: University of California Press, 2000). 
Lissarrague, François. Un flot d'images: Une esthétique du banquet grec (Paris: Adam Biro, 1987).

. Vases grecs: Les Athéniens et leurs images (Paris: Hazan, 1999).

Mulvey, Laura. Visual and Other Pleasures (Bloomington: Indiana University Press, 1987).

Silk, M.S. Aristophanes and the Definition of Comedy (Oxford: Oxford University Press, 2002).

Slapšak, Svetlana. "Aristofan i dva Škiljana," Monitor ISH 11 (2009) 71-83.

—. "Baubo: slika iz arheologije misoginije," ProFemina 10 (2004) 15-22.

Smoodin, Eric, ed. Disney Discourse: Producing The Magic Kingdom (London: Routledge, 1994).

Steinke, Jocelyn. "Cultural Representations of Gender and Science: Portrayals of Female Scientists and Engineers in Popular Films," Science Communication 27 (2005).

Stevanović, Lada. Laughing at the Funeral: Gender and Anthropology in Greek Funerary Rites (Beograd: Etnografski Institut, 2009).

Tselentis Apostolidis, Persephone. "Female Presence and Male Absence: Recent Films by Greek Women" Film Criticism 27 (2002) 43-58.

Vernant, Jean-Pierre and Françoise Frontisi-Ducroux. Dans l'oeil du miroir (Paris: Editions Odile Jacob, 1997).

Veyne, Paul, François Lissarrague, and Françoise Frontisi-Ducroux. Les mystères du gynecée (Paris: Gallimard, 1998). 


\title{
PANDORA-EVE-AVA: \\ ALBERT LEWIN'S MAKING OF A “SECRET GODDESS”
}

\author{
Almut-Barbara Renger
}

\section{Introduction}

The myth of the primordial woman, the artificially fabricated Pandora, first related in the early Greek poetry of Hesiod, has proven extremely influential in the European history of culture, ideas, literature, and art from antiquity to the present day. Not only did the mythical figure itself undergo numerous refunctionalizations, but, in a striking manner, particular elements of the narrative in the Theogony (Theogonia) and in Works and Days (Opera et dies) - for example, the jar, which would later be conceived as a box - also took on a life of their own and found their place in ever new cultural contexts. Having been drawn out from the "plot" (in the Aristotelian sense of $\mu \hat{v} \theta \circ)$, these elements formed separate strands of reception that at times interfered with each other and at other times diverged.

In the twentieth century such myth-elements also developed a distinctive dynamic of their own in film. Albert Lewin's Pandora and the Flying Dutchman (1951) offers a particularly original conception of the Pandora myth by interweaving its elements with the legend of the Flying Dutchman and plotting it into a story that takes place around $1930 .{ }^{1}$ It is the story of a young American woman, Pandora Reynolds, "bold and beautiful, desired by every man who met her" - so goes the original trailer of 1951, which opens with some introductory remarks about glamour by Hedda Hopper. $^{2}$

Lewin's intermingling of the Pandora myth and the Dutch legend in a love story of the 1950s is in many ways bold and original. The film effects a hybridization of two narratives from different cultural contexts and times. In front of a colorful setting of archaeological ruins and antique finds, Flamenco dance and Corrida, beach parties and motor racing, it intertwines overbearing material sensuality on the one hand with a seemingly spooky

\footnotetext{
1 Pandora and the Flying Dutchman, directed by Albert Lewin (England, 1951).

${ }^{2}$ Hedda Hopper of Press and Radio Fame Talks about "Glamour": Pandora and the Flying Dutchman. Bonus material of the DVD-Edition of Kino Video.
} 
extrasensory nature on the other. This is done in such a way that it produces a chimera of apparently natural supernaturalness, which led to varied criticism after the release of the film. While Anglophone critics ranked it as pretentious and trashy, the film was celebrated by French critics, who drew a connection to surrealists such as Luis Buñuel and Salvador Dalí. Lewin himself, a friend of Man Ray, who made two painted portraits and a color photograph of Ava Gardner for the film (only the photograph was used; the portrait seen in the film was made by Ferdinand Bellan), spoke likewise of surrealist influence.

However, all this - most of all the question about the surrealist subtext of the film as well as the possibilities and limitations of combining classic narrative film production with the surreal - has already been discussed by Susan Felleman, among others, in her book Botticelli in Hollywood, ${ }^{3}$ and is therefore not the subject of the following reflections. I shall examine instead the manner in which the motif-providing Pandora myth and the structure-providing Dutch legend are linked in Lewin's film. I demonstrate how the motivic elements in the myth - for instance, hope, Pandora's double nature as both evil and good, and her resemblance to Eve - have been fitted into Lewin's adaptation of the seafarer's legend and combined in an amorous melodrama. In all this I shall consider more closely, apart from Lewin's film, Hesiod's Pandora myth and the Dutch legend in Richard Wagner's opera with special regard to the concepts of gender relation and the images of the woman that underlie these two narratives and how they are portrayed in the film.

\section{The Filmmaker's Fabricated Figure}

Let us begin with the story of the film. It takes place in 1930 in Esperanza, a fishing village and holiday resort on the Spanish Costa Brava ("wild coast"). The nightclub singer Pandora is the much adored centre of a small group of British and American expatriates; several of the men in this group have

3 Susan Felleman, "How High Was His Brow? Albert Lewin, His Critics and the Problem of Pretension," Film History 7 (1955) 384-400; and Felleman, Botticelli in Hollywood: The Films of Albert Lewin (New York: Twayne, 1997) esp. 20-24 and 81-99. See also John H. Matthews, "Albert Lewin: Pandora and the Flying Dutchman (1951)," in Surrealism and American Feature Films (Boston: Twayne, 1979) 123-140; Jean-Paul Török, "Eva Prima Pandora," L'Avant-scène du Cinéma 245 (1980) 4-5; Marie-Claude and Pierre-Henry Frangne, "Avez-vous vu 'Pandora'? Remarques sur le cinéma d'Albert Lewin," Atala (1999) 95-106; and Raphaëlle Moine, "From Surrealist Cinema to Surrealism in Cinema: Does a Surrealist Genre Exist in Film?" Yale French Studies 109 (2006) 98-114. 
fallen in love with her with fatal consequences. Reggie Demarest (Marius Goring), exactly a year after getting to know Pandora, kills himself for her sake in front of her while she sings before the assembled audience. After she announces that the measure for love is what men are prepared to sacrifice for it, the motorcar racer Stephen Cameron (Nigel Patrick) plunges his racecar bearing the name "Pandora" over the cliffs (which results in Pandora's promise of marriage). And even the Spanish bull fighter Juan Montalvo (Mario Cabré), who is devoted to Pandora in a passionate and possessive lust, blindly and jealously courts her until he - having attempted to stab the one whom Pandora prefers over him - succumbs to his passion and dies. Thus the seductive young woman incapable of love has a destructive impact on all those who fall in love with her.

There is a turning point when a yacht lays anchor at Esperenza. Pandora swims towards it naked and finds the owner, Hendrick von der Zee (James Mason), painting a portrait in his cabin that is an exact image of her. ${ }^{4}$ Upon remarking that this is a surprising coincidence, the Dutchman replies that it is not a coincidence at all: he has painted a woman whom he has never seen before, but he has portrayed her as Pandora. Pandora subsequently falls in love with Hendrick. She answers "yes" to the question he poses to her one evening: whether she would die for him. When asked in return what he would willingly sacrifice for her, he offers her his immortal soul, but disappears soon thereafter in order to spare her from the sacrifice. Pandora then realizes that she is dealing with the Flying Dutchman, who, because he murdered his spouse out of jealousy and blasphemy, was condemned centuries ago to eternal sea-wanderings on his ghost ship until a woman sacrifices herself for him. Realising this, she swims back to the yacht, which is sailing to sea but caught up in a dead calm. Both declare their love for each other, and Pandora once again tells Hendrick that she is prepared to die for him.

What actually ensues remains unclear. A storm arises overnight, erupting with a bolt of thunder, and the next morning the yacht has disappeared. Apparently Pandora's and Hedrick's confession of mutual love and their embrace in a moment of suspended ecstasy lead to a union beyond space and time - to a mystical reunion, for it turns out that Pandora is the reincarnation or reappearance of the murdered spouse of the Dutchman. In their union Pandora and Hendrick save each other from the mutually analogous purgatories of a hopelessly dreary existence: from a life without

4 As mentioned above, this portrait is the painting by Ferdinand Bellan. 


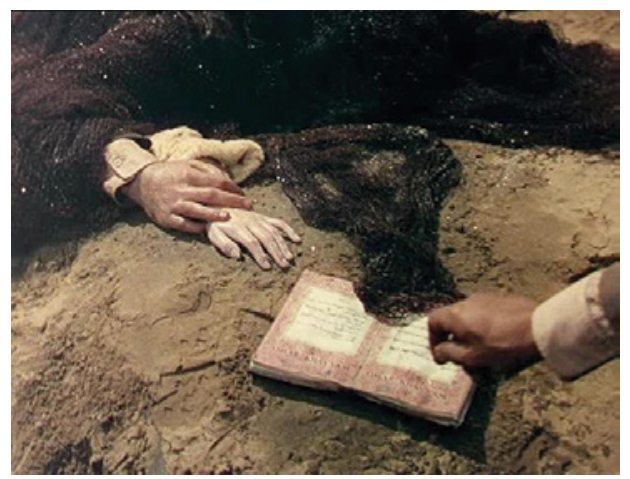

Figure 1

love and from a life without death. In this instance, as is common in art, literature, and music, love and death appear as closely linked with each other. The idea of lovers' mystical union, of the delimitating experience that merges love and death, is especially familiar from Romanticism and its offshoots, including Richard Wagner's death eroticism as well as Fin de siècle decadence. This idea in Lewin's film reaches a graphically expressed climax in a scene that is brought forward - thus making the film's ending superfluous - showing Pandora's and Hendrick's interlocked hands sticking out from a fishing net (see Figure 1).

Although this "ending" brought forward may be gloomy, it does shed light on the opening scene, which it concludes and to which the film's actual ending refers back. The picturesque and seemingly documentary opening scene follows the cast and credits and a picture of the Esperanza surf with explanatory, superimposed captions about the place and time of the narrated events. It shows local fishermen in their boats who chat and joke in non-translated Catalan while pulling in their nets; it ends with shock on the faces of the fishermen when they look down upon their catch. Only later, when the fishing net is ashore and the hands of the protagonists are shown sticking out of it, does the audience learn that these bodies have been caught. The film's ending takes this up, and it becomes clear: the ending is shown at the beginning and thereby creates a frame.

The story is visually presented in Technicolor along the Costa Brava in silvery bays, picturesque taverns, and elegant summer villas. Dorkay Productions/Romulus Film produced the luxurious color film which premiered on October 15, $195^{1}$ in American cinemas, distributed by MetroGoldwyn-Mayer. It was shot in the Shepperton Studios in London and in Tossa de Mar in Catalonia, a coastal place between rocky cliffs dropping 
steeply to the Mediterranean. This is where Lewin's Ava-Pandora came into being as the descendant of the ancient Pandora: oscillating between film goddess and goddess image, a cliché of the eternal feminine carved onto the screen in close-ups, and finally cast in bronze. Since 1998 there is a monument in Tossa de Mar that was created by the Catalonian woman artist Ció Abellí: a bronze statue of Ava-Pandora that lets her eye wander across the Bahía de Tossa, the bay of "Esperanza."

The creation of his Ava-Pandora puts Lewin in a long ancestry of male authors whose works confirm the thesis of Hans Belting's Anthropology of the Image (Bild-Anthropologie), namely, that the body is an image well before it has become a painted picture. ${ }^{5}$ Media such as literature, fine arts, and film decisively determine the common understanding of and relationship to the body as well the sexes. The perspective of an author and the view of a fine artist and film producer transmit a set of ideas and views that have an impact on the perception of the recipients and, emanating from them, have further impact. Thus Hesiod can be considered the first in the ancestral line that ends with Lewin. In the verses that describe Pandora's creation using various images, Hesiod created a body as an image called Pandora and thereby established a tradition of pictorial production that would last for centuries, as documented in Dora and Erwin Panofsky's study on the iconographic and motive-historical impact of Pandora (1956). ${ }^{6}$ In the course of the narrated events, Hesiod presents Pandora as the first woman and has her made at Zeus' command by the gods' blacksmith, Hephaestus. Lewin adopts this artificial woman thus released into literature and the arts, who up to his day had undergone numerous textual and visual transformations. He creates her anew, using the means offered by the color film at the time, as a young woman from Indianapolis staying at the Spanish Riviera. The American screenwriter-director thereby creates - just like the Greek poet in his own way - a fabricated female figure. Linked to gender concepts of its time of origin, a mirror of male desire, this figure bears the projections of its male creator, expectations towards woman, and the role of a woman in film in the 1950 .

5 Hans Belting, Bild-Anthropologie: Entwürfe für eine Bildwissenschaft (Munich: Fink, 2001) 89.

6 Dora Panofsky and Erwin Panofsky, Pandora's Box: The Changing Aspects of a Mythical Symbol (New York: Pantheon, 1956). See also Almut-Barbara Renger and Immanuel Musäus, ed., Mythos Pandora: Texte von Hesiod bis Sloterdijk (Leipzig: Reclam, 2002). 


\section{The Socio-Economic Background of Hesiod's Pandora}

To refresh our memory, I would like to offer some details from Hesiod's Theogony and Works and Days as well as some brief remarks about the socio-historical background of these poems. In Hesiod's works, the creation made by the gods' blacksmith on command from the highest god is an artificial product and is moreover labelled as feminine. It is a female creation made from clay, something "that resembles a bashful virgin"

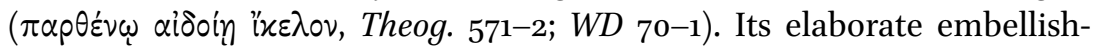
ment and decoration by the gods complete the creation begun by the blacksmith. The outcome of the joint work of the gods is the first woman, the progenitress of all women (WD 80, Theog, 590). She is given the name Pandora, sent to mingle among human beings, and opens a huge jar, a pithos ( $\pi(\theta \circ 5, W D$ 94,98). The consequences for humankind are fatal: they are now exposed to diseases, misery, and calamity; only hope or expectation, elpis ( $\dot{\varepsilon} \lambda \pi i \varsigma)$ remains inside the jar (WD 96$)$.

Hesiod's narrative should be read not least of all against the background of the poet's life as a landowner who found himself caught up in constant struggle with the uncertainties of everyday life. In view of the social and economic changes of his time, he saw humankind on a downward path to violence and injustice. His grim worldview also shaped his understanding of the role of women or rather the division of labor between the sexes in a rural agrarian economy. It allocated work in the field to men and domestic work to women. ${ }^{7}$ We learn about this gender segregation not only from Hesiod himself, whose Works and Days provides insights into the economic and social functions of a rural oikos, but also from Xenophon's Oikonomikos of the 4 th century Bс. ${ }^{8}$ At the time, an economically

7 On ancient European Economics, see, e.g., Kurt Singer, “Oikonomia: An Inquiry into Beginnings of Economic Thought and Language," Kyklos 11 (1958) 29-57; Ferdinand Wagner, Das Bild der frühen Ökonomie (Salzburg: Stifterbibliothek, 1969); Karl Polanyi, The Livelihood of Man (ed. Harry W. Pearson; New York: Academic Press, 1977) esp. 147-157; Winfried Schmitz, Haus und Familie im antiken Griechenland (Munich: Oldenbourg, 2007) esp. 13f. On the different areas of activitiy, roles and realms of man and woman in Greek domestic economy, see Lin Foxhall, "Household, Gender and Property in Classical Athens," Classical Quarterly 39 (1989) 22-44.

8 Xenophon's text concerns the ethical and practical aspects of the domestic management of an agricultural enterprise in Attica: about cultivation, animal husbandry, sale of property, the relationship of the inhabitants of the oikos among themselves, and the division of labor between landlady and landlord (see esp. ch. 7-9). Hesiod was already familiar with the double meaning of the word oikos (oixos) that Xenophon discusses: oixos in Works and Days concretely denotes the house, especially the farmhouse $\left(131,15^{0}, 364,523,554\right.$, and 627) and in some instances also takes on the more complex meaning of household 
and ethically well-grounded domestic and agricultural economy was considered as a source of affluence and well being, with the effective division of labor as a means for increasing the quality of production.

If we look at Hesiod's portrayal of Pandora against this background, namely that the activities of the countrywoman were confined to the domestic realm in a narrow sense, ${ }^{9}$ we are bound to conclude that we are dealing with projected fears with regard not only to sexuality but also to agrarian economy. ${ }^{10}$ The Theogony calls Pandora's creation a "beauti-

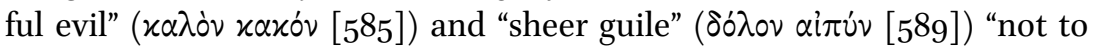

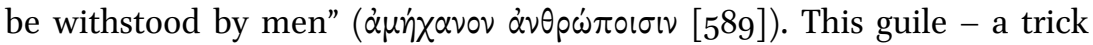
in response to Prometheus' trick, the sacrificial ruse - is to show that no one, not even the farsighted Prometheus, can deceive the highest god successfully. Pandora is an instrument in the fight between Zeus and Prometheus, an effective "by-product of a contest between males," as Froma Zeitlin puts it."1 By having her created artificially, Zeus uses a trick that simply cannot be challenged by anything. The effectiveness of his trick consists in the fact that the female creation in all its given adornment and glamour is extremely attractive and seductive yet opens the pithos with fatal consequences. The Theogony describes in full detail how Athena

with all the properties and persons belonging to it $(23,244,325,376$, and 495$)$. Both possible uses are already found in Homer, especially in the Odyssey, where the concrete usage is frequent. For the figurative denotation, see Odyssey 1.232; 2.64; and 4.181.

9 See Peter Spahn, "Oikos und Polis. Beobachtungen zum Prozeß der Polisbildung bei Hesiod, Solon und Aischylos," Historische Zeitschrift 231 (1980) 529-564, esp. 533-545 (about Hesiod).

10 Research on the Pandora myth among Anglo-American and Francophone scholars contains extended reflections with regard to the fascinating constellation of economics and sexuality in Hesiod's works. Reference is made to these here: Marylin B. Arthur [Katz], "Early Greece: Origins of the Western Attitude Towards Women," Arethusa 6 (1973) 7-58; Nicole Loraux, "Sur la race des femmes et quelques-uns de ses tribus," Arethusa 11 (1978) 43-87; Linda S. Sussman, "Workers and Drones, Labor, Idleness and Gender Definition in Hesiod's Beehive," Arethusa 11 (1978) 27-41; Jean-Pierre Vernant, "The Myth of Prometheus in Hesiod," in idem, Myth and Society in Ancient Greece (trans. Janet Lloyd; New Jersey: Humanities Press, 1980), 168-185; and Froma I. Zeitlin, "The Economics of Hesiod's Pandora," in Ellen D. Reeder, ed., Pandora: Women in Classical Greece (Princeton: Princeton University Press, 1995) 49-56. Reference is also made to a number of studies from Germanspeaking countries which plausibly demonstrate that in Works and Days an aition is given for the empty pithos as a storage vessel and that Pandora is seen as a "housewife" who as such disposes of its content: Eduard Schwartz, "Prometheus bei Hesiod," in Sitzungsberichte der Preußischen Akademie der Wissenschaften zu Berlin (1915) 133-148; Immanuel Musäus, Der Pandoramythos bei Hesiod und seine Rezeption bis Erasmus von Rotterdam (Göttingen: Vandenhoeck \& Ruprecht, 2004); Jakub Krajczynski and Wolfgang Rösler, "Die Substanz der Hoffnung: zum Pandora-Mythos in Hesiods Erga," Philologus 150 (2006) 14-27.

11 Froma Zeitlin, "Signifying Difference: The Myth of Pandora," in Richard Hawley and Barbara Levick, eds., Women in Antiquity: New Assessments (London: Routledge, 1995) 68. 
decorates the "commissioned work of art" with a glittering robe, an artistically made veil, and a sparkling gold diadem. In Works and Days she is

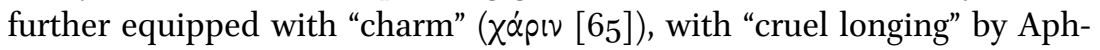
rodite ( $\pi \dot{0} \theta$ ov $\alpha$ pra $\alpha \lambda \varepsilon$ ov [sc. which he evokes in men] [66]) and with voice, speech, "a bitch's mind and a deceitful nature" by Hermes (xúveóv $\tau \varepsilon$ vóov xai غ̇ $\pi \dot{x} x \lambda \circ \pi \circ v \hat{\eta} \theta \circ$ [67]). The creation scene of the Theogony, which ends with the remark that from this female being the entire "female sex" had

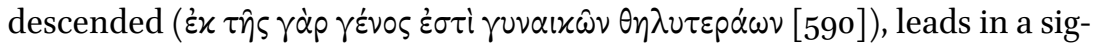
nificant way to the famous "drone parable." It shows in an exemplary way how ambivalently the woman is portrayed. The desire which she evokes in man is for him tricky insofar as there is an asymmetry in the division of labor. The woman is said to let herself be fed by the man like a drone: to enjoy the fruit of his labor without sharing the trouble and toil. Hesiod concludes that man can live well neither with nor without woman (cf. Theog. $590-612) .{ }^{12}$

Although the socio-cultural background is radically different, Lewin's modern Pandora has several points and features in common with Hesiod's Pandora. Both are creations that have come into existence in the conflict between the sexes. Both are creations and products of a male creator, which are produced in a discursive and performative manner by means of poetry and film. Just like the Greek first woman, Lewin's Pandora is dressed in a very attractive and enticing manner. She appears adorned in beautiful robes and artistically made veils (see Figure 2 ) and initially acts without a doubt as a "beautiful evil." The "cruel desire" that she evokes is fatal: the men who fall in love with her can live well neither with nor without her. As a result they are prepared to sacrifice everything to possess Pandora, even their own lives or those of others. The turn of events that Lewin relates through the perspective of his film with elegant camera movements and exquisite pathos is stunning: Pandora falls in love, realizes her destructiveness so far, and sacrifices herself for her beloved. What was the motivation and objective of such a presentation? Why and how did Lewin create such an Ava-Pandora, and for what reason? Why did he combine at the same time the Pandora myth and the legend of the Dutchman?

\footnotetext{
12 This portrayal by Hesiod is likely to have been equally close to his own opinion of women and the relationship of the sexes as it corresponds to the expectations and ideas of his audience. The viewpoint persists among other Greek poets; for example, Semonides of Amorgos.
} 


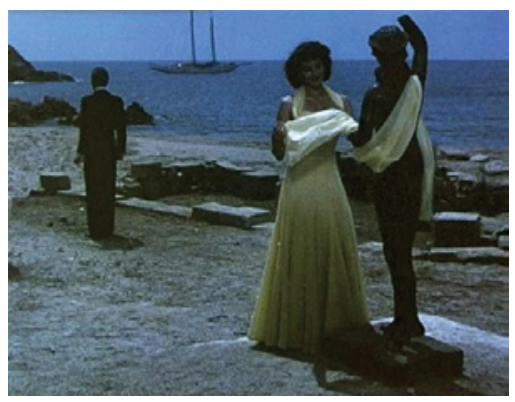

Figure 2

\section{The Emergence of the Film Goddess: Ava-Pandora}

Research into the film's development showed the following: when Lewin was shooting in Tossa, he would work with his team every day from seven o'clock in the morning until eight o'clock at night. During that time his whole attention was directed at Ava Gardner. "Lewin thought Ava was a goddess," the cameraman Jack Cardiff recalls. "He thought she was the most beautiful woman in the world, and he used to just gaze and gaze at her. And we would shoot her," Cardiff continues. "And he would say, 'I want to do another close-up. Closer.' "13 So the director asked for one close-up after another, and thus the Pandora of his film came into being.

However, during this creative work process, the well-experienced director was by no means in the clutches of Gardner's exquisite beauty and erotic aura. Rather, he pursued concrete interest while aiming at capturing her in artistic shots. Just like Hesiod's Pandora, his film figure emanates from a male-dominated struggle. Like Hesiod who competed with poets, like Zeus who fought with the Titans, Lewin found himself in a contest with the male authors, directors, and producers of Hollywood for the successful creation and production of stars. Film stars were even then what they still are today: living myths of enormous pull. Society takes hold of them for the purpose of certain messages. Their bodies are employed in everyday culture to serve, in the words of Roland Barthes, as "mythical signs"; narratives connected with them have a model character for the audience and provide them with answers to questions on the meaning of

13 Lee Server, Ava Gardner: "Love is Nothing," (New York: St. Martin's, 2006) 197. 
life. ${ }^{14}$ While in religious traditions narratives about the glorious deeds or ethical and religious perfection are linked to the bodies of inspiring figures and personalities such as heroes or saints, the bodies of stars created in the secularized world of film since the 1920 s tell of seemingly successful self-images: of desired self-realization, attention, and public celebrity. ${ }^{15}$ Therefore, the bodies of stars do not merely comprise fictitious roles on stage; the biographical person, the public appearance, the media publicity, and the characters they play all have a soothing and reassuring effect on the audience. When referring to stars and their audience, Leo Braudy has spoken of a kind of psychic medicine against feelings of loss and personal failure: the acquired fame conveys the message that narcissistic mortifications can be revoked and damaged life stories can be healed. ${ }^{16}$ This "medical" effect is particularly strong as long as the star is still in the making and his or her fame is increasing. But even if triumph is followed by setbacks and catastrophes, the star endows the audience with meaning and acceptation in the uneasiness of everyday life. The audience takes part in the highs and lows of the star's life through psychic transference and identification and adopts a part of his or her inspiring story as its own. In doing so, fans attempt to get closer to the star's physical appearance, for example by dressing in a similar way, having a similar hairstyle, and finding parallels in their own life stories.

The Hollywood studios already discovered the pull of the star's body in the 1920s and developed methods to make film actors into stars and market them successfully. When Lewin worked on his film in 1950, he was already well-acquainted with the star system. He had spent twentyfive years as a screenwriter and producer, especially with the MGM film production company, which advertised the slogan More stars than there

14 Barthes wrote a number of texts between 1954 and 1956 examining myth in areas as diverse as film, television, cooking, and photography. The texts appeared in 1957 for the first time as a collection under the title Mythologies in Paris; for an English translation see: Roland Barthes: Mythologies, Annette Lavers, trans. (London: J. Cape, 1972).

15 On this theme among others, see Werner Faulstich and Helmut Korte, Der Star: Geschichte - Rezeption - Bedeutung (Munich: Fink, 1997); Robert S. Sennett, Hollywood Hoopla: Creating Stars and Selling Movies in the Golden Age of Hollywood (New York: Billboard Books, 1998); Paul McDonald, The Star System: Hollywood's Production of Popular Identities (London: Wallflower, 2000); Elisabeth Bronfen and Barbara Straumann, Diva: Geschichte einer Bewunderung (Munich: Schirmer and Mosel, 2002); and Jeanine Basinger, The Star Machine (New York: A.A. Knopf, 2007).

16 Leo Braudy, The Frenzy of Renown: Fame and Its History (New York: Oxford University Press, 1997) 605. 
are in heaven and went furthest in carrying the star system to extremes. ${ }^{17}$ Even though there had been professional conflicts with MGM in 1945, and even though Lewin wrote and shot Pandora during a sabbatical from the production company, he still remained influenced by his work with them. He knew the glamour and the film industry well and knew how essential it was for a successful film to create the body of a star onto which the audience could project its desires and wishes. He created Ava-Pandora so

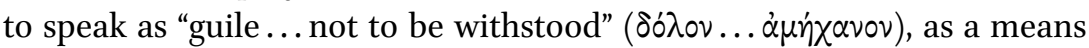
to combine cultural mainstream taste and expectations with his own preference for the surreal, thereby safeguarding his own qualifications and position. When he chose Gardner, who had signed a contract with MGM in 1941, for the role of Pandora, she was not yet considered one of the "queens of Hollywood," but she was about to make a breakthrough as a star. With his Ava-Pandora Lewin was hoping for a successful film presentation of a new female glamour star - a film goddess.

We find a reflection of this intention in Hedda Hopper's abovementioned brief introduction to the original trailer of $195^{1}$ as well as in an article in the daily newspaper Toledo Blade. ${ }^{18}$ At the time Hopper was one of the most influential gossip columnists. Her articles were syndicated in the press across the entire country and therefore had enormous power to influence the career of a star. ${ }^{19}$ In the trailer Hopper emphatically promotes the rising star: “... for my knowledge Ava Gardner will be Miss Glamour of 1951." ${ }^{20}$ In Toledo Blade she further suggests that Lewin's choice neither fell on Ava Gardner by coincidence nor was motivated merely by personal liking. The columnist highlights the reasons why the part was given to Gardner in the following way: "With features of classic purity, she has a beauty that is international. Like a Greek statue, she can be attractive to men of all times and nations." ${ }^{21}$ Hopper further reports that Lewin was not only concerned about the production of a beauty with a broad impact but also to find an actress who was convincing as an "object of desire": "[F]our men were in love with Pandora, and I had

17 Lewin became a scriptwriter with MGM in 1924. By the end of the 1920's he worked as the company's head of the film script department and as personal assistant and confidante of Irving Thalberg. In the 1930's, now officially as "associate producer," he produced some of the greatest success films for MGM. See, e.g., Felleman, Botticelli in Hollywood, 2-7.

18 Hedda Hopper (Hedda Hopper Writes): "Ava Gardner Climbed Slowly to the Top," Toledo Blade, Sunday, July 1, 1951, 10 (Section 6).

19 Sennett, Hollywood Hoopla, 40.

20 "Hopper of Press and Radio Fame," Kino Video Edition.

21 Hopper, "Ava Gardner Climbed," 10. 
to have a girl of such beauty that audiences could understand why ..."22 This beauty, so the article tried to convey, was at any rate complemented by erotic radiance.

Of particular significance were, furthermore, the parts that Ava Gardner had taken before. With her first big performance beside Burt Lancaster in Robert Siodmak's The Killers (1946), she was already assured in her role as a vamp of enticing beauty. In 1948, under the direction of William Seiter in One Touch of Venus, she played a goddess with the aid of a statue in a store that was brought to life through the burning love of an employee and that, after slipping into the body of a shop assistant, turned into stone again. Seiter's film comedy is an adaptation of a musical with the same title by Kurt Weill, which is based on a tale inspired by Pygmalion-Galatea material, The Tinted Venus (1921) by Thomas Anstey Guthrie. Here, too, woman is portrayed as a being artificially created by man. It was therefore Lewin's aim to bring to the stage once again such a being, with seemingly ancient props, and to obliterate the boundaries between nature and art through film.

The experienced film director achieved this without any doubt. Just as in Hesiod's fiction - with a "team of helpers" who all contributed a gift during creation - Pandora was produced with Jack Cardiff as an excellent cameraman. Attractively arranged with cosmetics by a make-up artist, magnificently dressed in a different robe for each scene by the costume designer Beatrice Dawson, and effectively dipped in the dazzling Mediterranean daylight or naked in phosphorescent moonlight, the actress appears in Lewin's film melodrama as a perfectly shaped glamour star, as the resplendently beautiful Ava-Pandora. Camera control and cutting contribute to this in a decisive way: through the manner in which half totals are cut to close-ups of the face and the body, Pandora's natural beauty is artistically accentuated - at one time by way of long elegiac camera focus resulting in closeness and atmosphere, and at other times through quick cutting sequences that bring Pandora into optically strong constellations with spectacular car races and bull fights, gorgeous parties, and moonlit idylls. A central scene sequence is suitable for illustrating this in an exemplary manner: after Pandora has swum naked to the yacht of the Dutchman and emerged in front of it from the sea of Esperenza, where the moonlit water just about conceals her swimming body, she is shown in front of and on the yacht in eroticising fragments in a relatively short

22 Albert Lewin, cited in Hopper, "Ava Gardner Climbed." 


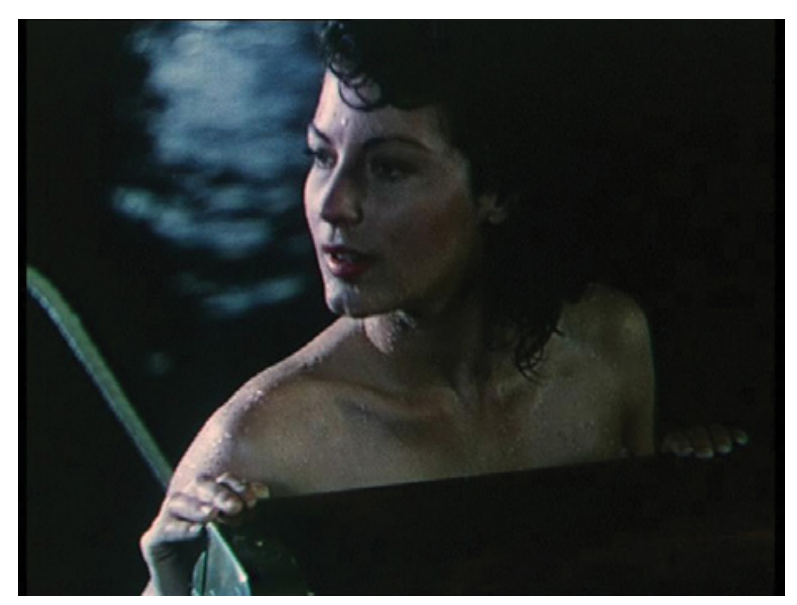

Figure 3

cutting sequence. First one can see her face moistened with sea water and her glistening shoulders, then the back of her head and upper back, and finally several times her dripping hair which surrounds her face (see Figure 3). Upon climbing on board, she reaches for a canvas on a cabin hatch and her arm is briefly faded in, and then she walks wrapped in the canvas on tiptoes towards a door to the cabin in order to climb down into it; when doing so, her naked feet are visible.

\section{Death, Love, and Redemption}

The sequence of scenes in front of, on, and in the interior of the ship, when the protagonists meet for the first time, are of key importance. They show the development of the lover who, through her readiness to die, saves the beloved, forming an erotic moment of abandonment and attachment at the same time. Pandora emerges from the sea naked like the ancient goddess of love Aphrodite/Venus and barefoot begins to walk a Christian-Germanic inspired "path of salvation" through love. By going on board and then disappearing in the interior of the ship, she passes a transit zone and enters the realm of eternal love beyond space and time. Greek myth and Nordic legend are thus diffused into a contemporary Christian version. In a subtle way several set pieces of the handed down Pandora myth are being woven into the legend of the Flying Dutchman. I shall therefore examine the sequence of scenes closely below. 
I would like to begin with the scene already mentioned, where Pandora climbs on board the ship and is thus introduced to the Dutchman's legend. The scene can be viewed as a film realization of the curiosity motive, especially against the background of the Pandora myth, which was consistently understood as a story of female curiosity, for instance by the film critic Laura Mulvey. ${ }^{23}$ Pandora has swum to the ship out of curiosity and opens "the lid of the jar" in which (in the belly of the ship) the Dutchman is found painting at his easel. In that very moment when Pandora pulls the canvas from the cabin hatch, in the figurative sense of opening the jar, plagues start escaping; at the same time, "hope" - evoked by the Spanish name "Esperanza" - remains. It is so to speak "the treasure" that, according to the film's narrator and archaeologist Geoffrey Fielding (Harold Warrender), is to be found in Esperanza "at the bottom of the sea": it is the elpis of the Greek myth which remained after the opening of the jar - the hope which Pandora and the Flying Dutchman find when they find each other. While the archaeologist tells Pandora about his search for the treasure, his findings, and old legends, she shows little interest in what he is talking about and instead looks down upon the Bay of Esperanza at the strange yacht which has aroused her curiosity. She runs to the beach where she sheds her garments - and then plunges into the sea.

Once inside the belly of the ship, Pandora, immediately gets to hear all about mythology and ancient things, despite her disinterest in these subjects. With brush and palette in hand Hendrick van der Zee has just been working on a painting of the mythic Pandora and introduces her as the "darling of the gods" (see Figure 4).

Taking up the motif of curiosity which has driven Pandora Reynolds to him, he explains, "They gave her the precious box, that she was forbidden to open." A little while later he calls her "the first woman, the Eve of Greek legend, whose curiosity cost us our earthly paradise." This picks up on an ancient reception strand of the Greek myth. Pandora and Eve have regularly been contrasted, connected with each other, or even seen as one and the same in Christian interpretation dating back to Tertullian's $O f$ the Soldier's Garland (De corona militis 7,3), Origen's Against Celsus (Contra Celsum 4,38), and Against Women Who Wear Cosmetics by Gregory

23 Laura Mulvey, "The Myth of Pandora: A Psychoanalytical Approach," in Laura Pietropaolo and Ada Testaferri, eds., Feminisms in the Cinema (Bloomington: Indiana University Press, 1995) 3-19. With reference to Albert Lewin's film, Mulvey's thesis presents and discusses among others in detail Elisabeth Bronfen, "Pandoras Nachleben: Figuren weiblicher Neugierde," in Therese Fuhrer, Paul Michel and Peter Stotz, eds., Geschichten und ihre Geschichte (Basel: Schwabe, 2004) 361-382. 


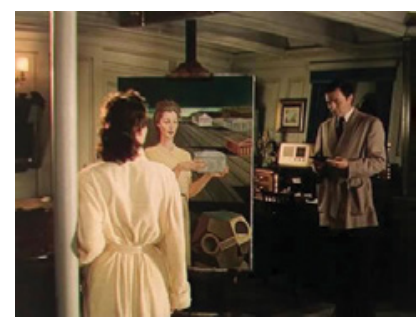

Figure 4

of Nazianzus (Kata gunaikōn kallōpizomenōn 115-122). Numerous parallels between the "first women" of mythology where they appear gave rise to this conflation. In both Hesiod's works and in the Bible, humans are made from clay. Both are considered responsible for the fact that humanity was moved from a paradisiacal state in which the effort to earn one's livelihood was hardly worth speaking of, to a postlapsarian state requiring laborious farming. These parallels, already observed in Patristic literature, led to numerous portrayals that linked the two "formed women" in Renaissance. ${ }^{24}$ The Renaissance after all was a time when ancient myths were received everywhere - in lyrics and narrative poetry, painting, sculpture and applied arts, theatre, ballet and festival - and apart from Hesiod, Origen was more and more received. Possibly the most prominent example from that time, which contributed immensely to the establishment of the Eve-Pandora link, is the creation by Jean Cousin (around 1550), the reclining nude of Eva Prima Pandora that can now be found in the Louvre. Cousin displays a beautiful naked woman posing in front of trees and an antique background; her right arm rests on a skull, which denotes transience, and in this hand she holds a branch, apparently from the tree of the perishable fruit. Coiled around her left arm is a snake that hints at the Fall of humankind; the hand lies languidly on an opened vase. Whether through this nude or through similar portrayals - for example, John Milton's prominent comparison of Eve and Pandora in Paradise Lost $(4.708-719)^{25}$ - the Christian interpretation that links Hesiod's Pandora

24 Edgar Wind, "The Revival of Origen," in Dorothy Miner, ed., Studies in Art and Literature for Belle da Costa Greene (Princeton: Princeton University Press, 1954) 412-424.

25 The equation of Eve and Pandora in Milton's Paradise Lost is certainly just as well known and equally important for the further history of reception as Cousin's picture. Book IV contains the description of the first marriage. Here, Eve is described as a richly adorned bride who infatuates because of her beauty, and as such is compared with Pandora, the woman richly endowed by the gods. For further examples, see Panofsky, Pandora's Box, $27-113$. 
to the Eve of Genesis 3 is clearly known to the much travelled and erudite Hendrick. He therefore informs the young American woman who declares she has no interest in old myths and legends about the mythological figure at their first encounter.

The fact that the Eve-Pandora equation is found at this point of the film, especially coming from the mouth of the Dutchman, is not surprising for several reasons: first, the entire setting of the film's events with its geographical and cultural localization and timing in Spain during the 1930s is intermingled with Roman-Catholic elements. The bullfighter Montalvo for instance, the personification of this culture, requests a confession before dying. He has a priest by his deathbed and considers his death a punishment from God. "It is God's punishment... I have made confession. I am cleaned." Second, the staging of Pandora's body in front of and on board the yacht, the transitory place of her entry into the Dutch legend, portrays a revocation of femininity by way of uncovering and covering nakedness: in the intellectual history and illustrative tradition of Christian-Occidental culture this can hardly be perceived without Eve. Third, and most important, the setting of the Dutchman's legend, which is here interwoven with the Greek myth, has a Christian character in terms of its blasphemy motif. A flashback shows the Flying Dutchman in court following the murder of his wife (see Figure 5).

After the judge has passed a death sentence on him, when asked whether he would still like to say something, the Dutchman exclaims that he would repeat the bloody deed and wants neither a priest nor any mercy, a bold proclamation that provokes his cursed odyssey. "Eternal penance be my comforts! Faith is a lie and God himself is chaos! Faith is a lie and heaven is a deception!"

Furthermore, it can be assumed that the Dutchman's Eve-comparison comprises a reference to the fictitious Lulu-figure. G.W. Pabst had made Lulu famous in his silent picture Pandora's Box (Die Büchse der Pandora) of 1929, which summarizes the Lulu dramas of Frank Wedekind, with Louise Brooks in the starring role (see Figure 6).

This "Louise-Lulu" is the cinematic predecessor of Ava-Pandora. Just like Louise Brooks as Lulu, Ava Gardner as Pandora was meant to become a successful glamour product. Accordingly, just like Hesiod's creation of a woman and Pabst's production of a silent film star, Lewin's creation - as an artificially made body and epitome of seductive femininity - was the result of cosmetics and, as Elisabeth Bronfen aptly puts it in regard to the film, of "scenic illumination," a skilful combination of long and 


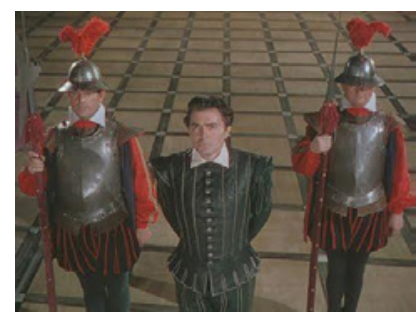

Figure 5

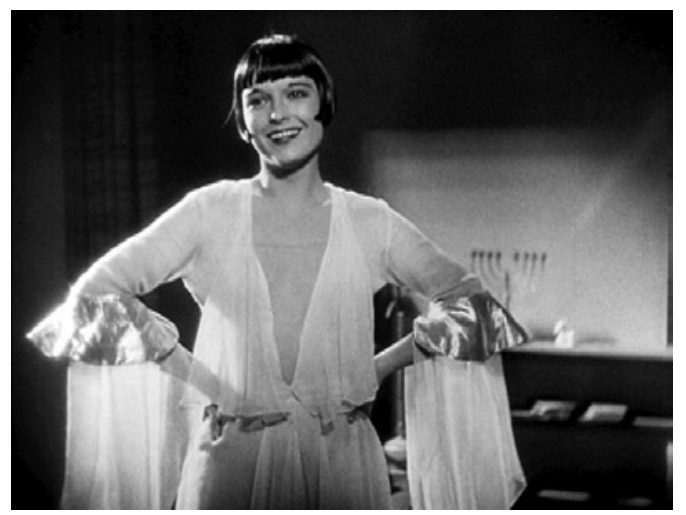

Figure 6

close-up shots. ${ }^{26}$ It is therefore hardly by coincidence that Pandora Reynolds is associated with Eve via the image of the ancient Pandora. Among the readings of the feminine, which in addition to the Pandora myth appear in Wedekind's dramas Earth Spirit (Erdgeist, 1895) and Pandora's Box (Die Büchse der Pandora, 1902), "Eve" is also mentioned as a name and symbol of seductive power. Wedekind's Lulu appears in different female parts which her lovers or husbands offer her. This means she appears in the respective parts as a woman created from a male perspective. The painter Schwarz (literally, "Black"), who has been fatally seduced by her and who, now dependent on her, is poisoned by her, calls her Eve. This name chosen by him is mentioned several times in Earth Spirit and the other plays as the first word in the first scene of the second act. Here Lulu, clothed in a green silky morning dress, enters the stage and shortly afterwards

26 Bronfen, Pandoras Nachleben, 370. 
Schwarz also appears with brush and palette in hand: "Eve!"27 During their first encounter, the dark-minded Dutchman calls Pandora Reynolds Eve; Hendrick too, like Schwarz, has brush and palette in hand. Admittedly, the relationship between the painter Hendrick van der Zee and Pandora Reynolds is entirely different from that of the painter Schwarz and Lulu. Hendrick remains independent and sovereign; Pandora remains attached to him and changes through her encounter with him.

This "casting of the parts," like so many other things that determine and mark the further course of events, is already suggested in the key scene on board the yacht, during the protagonists' first encounter. When Pandora approaches Hendrick's painting, she realizes that she could have acted as a model for the face of the portrayed woman. This discovery confuses her, especially since the picture - as she sees it - does not show her as she really is but as she would like to be. Unusually distraught, Pandora asks while looking at the painting: "Why am I not like that?" Then, in an outbreak of anger, she paints over the face with strong brushstrokes. Hendrick does not respond with anger as Pandora expects but rather shows himself inspired: 'You haven't hurt my painting, you have helped it." He grasps the brush and paints an egg shaped skull as Pandora's head, a white mask worn by many surrealistic Manichini of Giorgio de Chirico (see Figure 7$) \cdot{ }^{28}$

Hendrick justifies his modification by saying it was wrong of him to portray Pandora as a specific woman. And he continues: "Pandora should appear as woman in the abstract: bride and mother, the original and generic egghead, from which we can imagine the whole human race to have been hatched." She, Pandora Reynolds, had contributed the unexpected element that his picture still needed. Now, it really portrayed Pandora.

When Pandora Reynolds sees the faceless image, she defiantly remarks that it may well be Pandora, but it is certainly not her. Hendrick anticipates the ensuing events: once he gets to know her better, he will be able to restore the picture's resemblance to her, since he has after all the advantage of an unusual model who could inspire him to transform the picture into the image of Pandora Reynolds, the "secret goddess, whom all men in their hearts desire."

27 Frank Wedekind, Der Erdgeist, in Erhard Weidl, ed., Lulu. Erdgeist. Die Büchse der Pandora (Stuttgart: Reclam, 1989) 26, 32, and 48.

28 For specifically art-theoretical interpretations of the film and this scene with special attention to surrealism, see footnote 3, especially, Felleman, Botticelli in Hollywood, 87-89. 


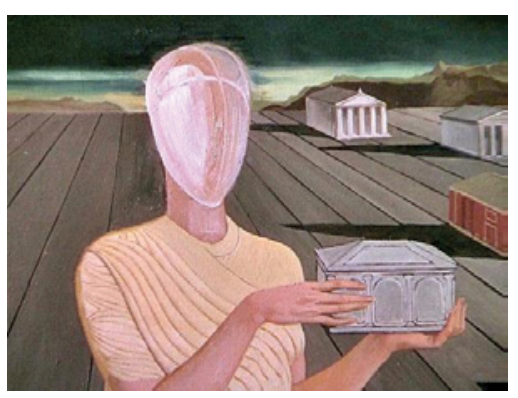

Figure 7

Pandora leaves the yacht visibly impressed. When she later swims to the ship again, at the film's end, Hendrick has concretized the picture coherently according to her judgement. "You restored the painting.... It's beautiful." The abstract oval image of the head is filled with her characteristics, the characteristics of the Dutchman's spouse whom she once was, and at the same time of the woman she has become: the one who devotes herself to the beloved man and creator of her picture, prepared to offer herself in order to fulfil his vision - redemption for and in death. In this function, looking at the picture and in the face of death, Pandora Reynolds recognizes herself in the last scene as the one she in fact is: a loving redeemer. When Hendrick asks, "You are not afraid to die?", she seals her self-perception that she gained through her encounter with him, both verbally and with physical gestures, replying "I am not afraid!" and moving towards him. She then gives herself totally to the pull of the deadly-erotic embrace. A kiss follows and immediately after a thunderclap is heard and a massive storm breaks out. Has all-engulfing death taken hold of the lovers?

The following settings suggest such an assumption: The learned archaeologist and film's narrator Geoffrey, whose academic interest in the ineffable, the occult, and the supernatural reflects Lewin's own fascination with these phenomena, observes through his telescope how the ship capsizes in the storm. Geoffrey sees on the shore that the fishermen have pulled out bodies in their nets, bodies identified as the corpses of Hendrick and Pandora. However, the film ends with a comment by the narrator who conveys that the ending had been a happy one for the protagonists and that the narrated events should not be approached with a controlling mind and the rationalism of a world that has lost its faith. In regard to the latest events, Geoffrey speaks of a "message not of death, but of life" and emphatically contemplates the possibility of a redeeming love victorious 
over death. In doing so he does not conceal - and here is a special climax - that he would not want to go public with such an interpretation as this. Otherwise, he would only receive pitiful comments such as, "Poor Geoffrey lost his wits poring over old religions!" And he adds: "Because we live in a time that has no faith in religions. We live in a time that has no faith."

\section{Wagner, Lewin, and Traditional Concepts of Gender Roles and Redemption}

The "mystery" of the "religiosity of love" that the film portrays against the diagnosed faithlessness within a Christian milieu makes for a highly questionable offer. Pandora's role model of a secret goddess created by a man for the fulfilment of his longing for salvation is not only unrealistic but is also unmistakably accomplished at the expense of women. It appears obsolete today.

However, in 1951 Lewin's film corresponded to a dominant discourse about masculinity and femininity. The film does differ from the bulk of mainstream productions of its time in that it makes it possible for the audience to view the process of the creation of the "goddess" in a vanguard-discursive manner, primarily through the conversations concerning the creation of the Pandora painting. In his gender portrayal, however, Lewin does not abandon well-trodden paths in any way. While Pandora's picture and its completion by Hendrick may appear like a metatext of the film, which comments on the establishment of a star-imago and the fabrication of gender identities and constructs, this certainly does not mean that the film itself deconstructs these identities and constructs and/or offers progressively empowering models of femininity. On the contrary, the relationship between director or producer and star, between Albert Lewin and Ava Gardner, is matched in the film by a hierarchical dualism of man and woman that translates into traditional agreements about gender dichotomy: the woman represents body, the man represents mind; the man produces, the woman is product; she "sits" on the beach, he enjoys restless motion. These binary, oppositional gender codings include a hierarchical downward trend: in distinction to the representative of the intellect crossing the seas, an Odysseus of the north, Pandora's fatality collapses just like the power of the sorceress Circe or the Sirens once fell before Homer's Odysseus. It is the man who ultimately demonstrates strength. Indeed, the Dutchman feels attracted by the night club singer on the "wild 
coast" (with her enticing song she finds herself at the end of a long line of female figures in the history of text and picture that began with Circe and the Sirens); ${ }^{29}$ but just as Homer's Odysseus (admittedly for different reasons: in order to spare the woman her sacrifice) Hendrick decides not to stay with the one who attracts him, but to travel on. Mystical union and death only arise from the fact that Pandora follows the beloved to his ghost ship prepared to sacrifice herself.

Among the multitude of traditional concepts of gender roles and gender relations that may have influenced Lewin in his production was a source that seems to have specifically inspired him, namely Richard Wagner's opera The Flying Dutchman (Der fliegende Holländer) that was premiered in $1843 .{ }^{30}$ In his works, Wagner created a store of musical leitmotifs, concepts and images that became part of collective memory. Lewin evidently reverted to this store. His film and Wagner's Romantic Opera in Three Acts display significant similarities and parallels on the level of both structure and content.

In the first act of The Flying Dutchman the eponymous protagonist, who is allowed to go ashore only every seven years, hopes for the unrestrained love of a woman who will remain faithful to him, so that he will finally be redeemed together with his crew and may die on Judgment Day. The opening monologue reveals that he has several failed suicide attempts behind him. Seven years have just passed again, and he proposes marriage to Senta, the daughter of a Norwegian sailor. In the second act, Senta asks to be told the legend of the Flying Dutchman, whose cheerless and isolated character has won her sympathy, while all the other girls who have heard of him are gripped with horror. While Senta is courted by the young hunter Erik, she forgets everything else in view of the gloomy image of the sailor and feels called to redeem him. When her father enters the room with the Dutchman, she knows that it has fallen to her lot to carry out the act of redemption. An intimate understanding develops between her and the Dutchman; the connection is being prepared. In the third act Erik asks Senta to remember her former love, which is overheard by the Dutchman. Certain that Senta will not remain faithful to him as he had hoped, and in order to protect her, he tells her - as she already knows -

\footnotetext{
29 See Almut-Barbara Renger, Zwischen Märchen und Mythos: Die Abenteuer des Odysseus und andere Geschichten von Homer bis Walter Benjamin (Metzler: Stuttgart, 2006) 201-315.

30 Richard Wagner, Sämtliche Werke, vol. 4, Der fliegende Holländer: Romantische Oper in drei Aufzügen (ed. Egon Voss; Mainz: Schott, 2001).
} 
about his curse and hurries to his ship so as to remain unredeemed. Senta, however, follows him and declares with a loud voice: "Here I stand, faithful to you until death," and hurls herself from the rock into the sea. The ship of the Dutchman, who has thus been redeemed, sinks into the sea. In a corrected version of the ending from the year 186o, the Dutchman and Senta, accompanied by the redemption leitmotif, ascend from the sea into heaven.

What particularly catches the eye when one compares the film and the opera is the similarity in the relationship of the protagonist couple. In Pandora and the Flying Dutchman the gender roles and the figurative model of their construction vis-à-vis Wagner's opera are not fathomed anew, as one might expect, but are adopted and reproduced in a stereotypical way: the film sets an eternal man against a mortal woman who is "defatalized" by his presence. In the end Pandora Reynolds fulfils the function of Senta who loves unconditionally; her old Pandora existence is transferred to a new one, that of Senta. The gender relationship that Lewin thus projects onto the screen purports that the woman - like Gretchen in Goethe's Faust, like Senta in Wagner's opera - exists beyond seduction and temptation through the love for a man. ${ }^{31}$ Prepared to give up her life hitherto oriented in a sensual-material direction, having accepted her fatal function as well as her promise of marriage to her fiancé, the young American sacrifices herself for the Dutchman and saves him from his curse to be forever tossed between death and life.

With this ending, a Liebestod, Lewin also "brings" to an "end" the destructive, fatal, ominous femme fatale as she is still portrayed in Wedekind's dramas and Pabst's film adaptation of Lulu. Even if Pandora Reynolds initially appears as an enigmatic woman of striking sensuality and excessive moral conduct who through her charm and intellect infatuates men in such a way that they die or at least experience harm, she herself in the end succumbs to love with deadly consequences. It is partly through this fact that she clearly differs from the attributions of the femme fatale identified for instance by Ulrike Prokop, Christa Rohde-Dachser, and Carola Hilmes. ${ }^{32}$ She is not the ever-"narcissistic" woman who finds acknowledg-

31 On Senta, see Gretchen John Deathridge, “Wagner's ‘Pale' Senta,” The Opera Quarterly 21 (2005) 452-464.

32 Ulrike Prokop, Weiblicher Lebenszusammenhang: Von der Beschränktheit der Strategien und der Unangemessenheit der Wünsche (Frankfurt am Main: Suhrkamp, 1976) esp. 130; Carola Hilmes, Die Femme fatale: Ein Weiblichkeitstypus in der nachromantischen Literatur, (Stuttgart: Metzler, 1990) esp. 10; Christa Rohde-Dachser, Expedition in den dunklen Kontinent: Weiblichkeit im Diskurs der Psychoanalyse (Frankfurt am Main: Fischer, 1997) 
ment in herself and is autonomous in her desire. As the one who sacrifices herself with devotion, she in fact runs contrary to the feminine idol that was conventionalized especially in the late nineteenth- and early twentieth-century into a figure of feminine fatality in literature and film. ${ }^{33}$ Her male creator replaces sexual autonomy with passion and self-sacrifice for the beloved by means of colour-charged pictures that aestheticize the events, allowing the active living woman to undergo a transformation into a dying passive one. Who would not be reminded in this context of Edgar Allen Poe's prominent sentence from his essay The Philosophy of Composition, ${ }^{34}$ namely, that the death of a beautiful woman was doubtlessly the most poetic theme of the world? Especially when considering the research on this issue presented by Elisabeth Bronfen (for instance in Over Her Dead Body), among others, the thesis suggests itself - with Pandora's film-aesthetic transformation into a suicidal Senta in mind that the male order is to be restored and that proven differences are to be newly constructed or safeguarded..$^{35}$

This thesis proves true in comparison with Pabst's Pandora's Box, especially when we become aware that both creators, Pabst and Lewin, let their Pandora die. The only difference is that the taming of what eludes male grasp in the $195^{\circ}$ film develops in a more complex way. The fatal Lulu's end is brought about by a knife; the fatal Pandora Reynolds' by suicide. Pandora and the Flying Dutchman replaces the myth of the woman as staged in Pandora's Box: a myth by means of which desires and fears are aestheticized (Pandora/femme fatale) through another myth with identical function (Senta/Liebestod). In fact, Lewin could have changed the course of events and corrected the Dutchman's legend in modern enlightenment style through the elimination of Liebestod. But he took over Wagner's plot, the understanding of gender relation implemented therein, and the suicidal tendency of Wagner's protagonist couple. The pale Hendrick is presented on screen as a depressive and isolated character with monumental

esp. 158. On this theme, see also Stephanie Catani, Das fiktive Geschlecht: Weiblichkeit in anthropologischen Entwürfen und literarischen Texten zwischen 1885 und 1925 (Würzburg: Königshausen \& Neumann, 2005) 90-97.

${ }^{33}$ For an extensive overview of this figure, see Mario Praz, The Romantic Agony (trans. A. Davidson; Oxford: Oxford University Press, 1991) 197-300.

34 Edgar Allan Poe, "The Philosophy of Composition," in Graham's Lady's and Gentleman's Magazine 28.4 (1846) 163-167 (first printing).

35 Elisabeth Bronfen, "Die schöne Leiche: Weiblicher Tod als motivische Konstante von der Mitte des 18. Jahrhunderts bis in die Moderne," in Inge Stephan and Renate Berger, ed., Weiblichkeit und Tod in der Literatur (Cologne: Böhlau, 1987) 87-115; and Bronfen, Over Her Dead Body: Death, Femininity and the Aesthetic (New York: Routledge, 1992). 
gloomy appearance, and Pandora with him posing as a yearning woman who desires to die with her beloved. ${ }^{36}$ This corresponds to the gender relationship as frequently produced in Wagner's operas: on the one hand there is the woman who loves unconditionally and thereby redeems the man by facing her own death; and on the other hand, there is the male hero who goes his way unperturbed. ${ }^{37}$ Lewin does not give his Dutchman the demystifying idea of living peacefully with a woman and thereby averting the curse. Instead, he lets him consent to the offer of self-sacrifice rather relieved - equally desirous of death as his predecessor - and lets him and the one who loves him see a gift in the life of the woman who assists the man in bringing about the desired death.

The circumstance of Pandora's self-sacrifice that allows her life to be seen as a gift for the redemption of the man from death can also be read, as Sigrid Weigel does, in the sense of the thesis proposed above. In her prominent essay on "the sacrified heroine" and "the sacrifice as heroine," Weigel analyses feminine images from the point of view of the sacrificial role. ${ }^{38}$ She concludes among other things that since the eighteenth century - that is, since the time in which a decrease in rites of sacrifice is noted - images where the woman is offered as a sacrifice increase in a striking manner; and Weigel interprets this phenomenon as a means to "guarantee the continuance of male culture":

The death or the giving herself of the woman in literature ensures the exclusion of the woman in the cultural order. Both are expressions and symbols for the role of the woman as the one who gives herself and as such she is nevertheless part and parcel of the same order. ${ }^{39}$

In making reference to the production of feminine images whereby male yearnings that cannot be satisfied in reality are projected onto the feminine other, Weigel writes:

\footnotetext{
36 Scholars have discerned Wagner's suicidal tendencies in The Flying Dutchman. See John Louis DiGaetani, Wagner and Suicide (Jefferson: McFarland, 2003) 21-36. Considerations of this nature about Albert Lewin are not to be undertaken here.

37 On Wagner, see Eva Rieger, "Leuchtende Liebe, lachender Tod": Richard Wagners Bild der Frau im Spiegel seiner Musik (Düsseldorf: Artemis \& Winkler, 2009).

38 Sigrid Weigel, "Die geopferte Heldin und das Opfer als Heldin: Zum Entwurf weiblicher Helden in der Literatur von Männern und Frauen," in Inge Stephan and Sigrid Weigel, eds., Die verborgene Frau: Sechs Beiträge zu einer feministischen Literaturwissenschaft (3rd ed.; Hamburg: Argument, 1988) 138-152.

39 Ibid., 144.
} 
Such images are fascinating and alarming at the same time; therefore their creators have to kill them... The author sacrifices his creation - and penalizes it for its outbreak into unfeminine 'grandiosity'.

If we consider the socio-historical background in which Lewin's film develops, it becomes clear that the sacrifice of his creation was in keeping with a historically conditioned tendency of the Hollywood cinema of the day. During the Second World War, due to fact that men became soldiers in the war and women increasingly went into employment, more and more films with strong female characters had come about. This for instance went hand-in-hand with film noir in a significant increase in productions of fatal women. At the end of the war things changed: many women became unemployed again during the second half of the 1940's, and men took over their positions. The resultant analogy to this in film meant that the image of the obliging woman became generally accepted again, that is, the autonomous woman was sacrificed. ${ }^{40}$ Collective and individual breaches and rifts of the war and postwar society were thus to be compensated. Stability was to brought about by reverting to old roles.

Knowing that the images produced by the star's body had to be oriented towards the needs of the audience and its expectations, fantasies, and aspirations in order to make the film successful, Lewin clung to this tendency. He sacrificed the autonomous and uncontrollable femme fatale and created Pandora as a redemptive figure inspired by Christian thinking. Her self-sacrifice out of love contains the message that the destructiveness of a femme fatale, the curse of hopeless restlessness and a life without love, are revocable. Thus Lewin filled the mythical sign "star" with hope for redemption by way of the materiality of Ava Gardner's body and the idea of erotic redemptive love.

\section{Works Cited}

Arthur, Marylin B. [Katz], "Early Greece: Origins of the Western Attitude Towards Women," Arethusa 6 (1973) 7-58.

Barthes, Roland. Mythologies (trans. Annette Lavers; London: J. Cape, 1972).

Basinger, Jeanine. The Star Machine (New York: A. A. Knopf, 2007).

Belting, Hans. Bild-Anthropologie: Entwürfe für eine Bildwissenschaft (Munich: Fink, 2001). Braudy, Leo. The Frenzy of Renown: Fame and Its History (New York: Oxford University Press, 1997).

40 Michael Sellmann, Hollywoods moderner film noir: Tendenzen, Motive, Ästhetik (Würzburg: Königshausen \& Neumann, 2001) 97-104. 
Bronfen, Elisabeth. "Die schöne Leiche: Weiblicher Tod als motivische Konstante von der Mitte des 18. Jahrhunderts bis in die Moderne," in Inge Stephan and Renate Berger, eds., Weiblichkeit und Tod in der Literatur, (Cologne: Böhlau, 1987) 87-115.

— . "Pandoras Nachleben: Figuren weiblicher Neugierde," in Therese Fuhrer, Paul Michel, and Peter Stotz, eds., Geschichten und ihre Geschichte (Basel: Schwabe, 2004) 361-382.

- Over Her Dead Body: Death, Femininity and the Aesthetic (New York: Routledge, 1992).

Bronfen, Elisabeth \& Barbara Straumann. Diva: Geschichte einer Bewunderung (Munich: Schirmer and Mosel, 2002).

Catani, Stephanie. Das fiktive Geschlecht: Weiblichkeit in anthropologischen Entwürfen und literarischen Texten zwischen 1885 und 1925 (Würzburg: Königshausen \& Neumann, 2005) 90-97.

Deathridge, John. “Wagner's 'Pale' Senta," The Opera Quarterly 21 (2005) 452-464.

DiGaetani, John Louis. Wagner and Suicide (Jefferson: McFarland, 2003).

Faulstich, Werner \& Helmut Korte. Der Star: Geschichte - Rezeption - Bedeutung (Munich: Fink, 1997).

Felleman, Susan. Botticelli in Hollywood: The Films of Albert Lewin (New York: Twayne, 1997).

—. "How High Was His Brow? Albert Lewin, His Critics and the Problem of Pretension," Film History 7 (1955) 384-400.

Foxhall, Lin. "Household, Gender and Property in Classical Athens," Classical Quarterly 39 (1989) 22-44.

Frangne, Marie-Claude \& Pierre-Henry. “Avez-vous vu 'Pandora'? Remarques sur le cinéma d'Albert Lewin," Atala (1999) 95-106.

Hilmes, Carola. Die Femme fatale: Ein Weiblichkeitstypus in der nachromantischen Literatur (Stuttgart: Metzler, 1990).

Hopper, Hedda. Toledo Blade, Sunday, July 1, 1951, 10 (Section 6).

Hopper, Hedda of Press and Radio Fame Talks about "Glamour": Pandora and the Flying Dutchman. Bonus material of the DVD-Edition of Kino Video.

Krajczynski, Jakub \& Wolfgang Rösler. "Die Substanz der Hoffnung: zum Pandora-Mythos in Hesiods Erga," Philologus 150 (2006) 14-27.

Lewin, Albert, Director. (England, 1951). Pandora and the Flying Dutchman (film).

Loraux, Nicole. "Sur la race des femmes et quelques-uns de ses tribus," Arethusa 11 (1978) $43^{-87}$.

Matthews, John H. "Albert Lewin: Pandora and the Flying Dutchman (1951)" in Surrealism and American Feature Films (Boston: Twayne, 1979) 123-140.

McDonald, Paul. The Star System: Hollywood's Production of Popular Identities (London: Wallflower, 2000).

Moine, Raphaëlle. "From Surrealist Cinema to Surrealism in Cinema: Does a Surrealist Genre Exist in Film?" Yale French Studies 109 (2006) 98-114.

Mulvey, Laura. "The Myth of Pandora: A Psychoanalytical Approach," in Feminisms in the Cinema, ed. by Laura Pietropaolo and Ada Testaferri (Bloomington: Indiana University Press, 1995) 3-19.

Musäus, Immanuel. Der Pandoramythos bei Hesiod und seine Rezeption bis Erasmus von Rotterdam (Göttingen: Vandenhoeck \& Ruprecht, 2004).

Panofsky, Dora and Erwin Panofsky. Pandora's Box: The Changing Aspects of a Mythical Symbol (New York: Pantheon, 1956).

Poe, Edgar Allan. "The Philosophy of Composition," in Graham's Lady's and Gentleman's Magazine 28.4 (1846) 163-167 (first printing).

Polanyi, Karl. The Livelihood of Man, ed. by Harry W. Pearson (New York: Academic Press, 1977).

Praz, Mario. The Romantic Agony (trans. A. Davidson; Oxford: Oxford University Press, 1991). 
Prokop, Ulrike. Weiblicher Lebenszusammenhang: Von der Beschränktheit der Strategien und der Unangemessenheit der Wünsche (Frankfurt am Main: Suhrkamp, 1976).

Renger, Almut-Barbara. Zwischen Märchen und Mythos: Die Abenteuer des Odysseus und andere Geschichten von Homer bis Walter Benjamin (Metzler: Stuttgart, 2006).

Renger, Almut-Barbara \& Immanuel Musäus, eds. Mythos Pandora: Texte von Hesiod bis Sloterdijk (Leipzig: Reclam, 2002).

Rieger, Eva. "Leuchtende Liebe, lachender Tod": Richard Wagners Bild der Frau im Spiegel seiner Musik (Düsseldorf: Artemis \& Winkler, 2009).

Rohde-Dachser, Christa. Expedition in den dunklen Kontinent: Weiblichkeit im Diskurs der Psychoanalyse (Frankfurt am Main: Fischer, 1997).

Schmitz, Winfried. Haus und Familie im antiken Griechenland (Munich: Oldenbourg, 2007).

Schwartz, Eduard. "Prometheus bei Hesiod," in Sitzungsberichte der Preußischen Akademie der Wissenschaften zu Berlin (1915) 133-148.

Sellmann, Michael. Hollywoods moderner film noir: Tendenzen, Motive, Ästhetik (Würzburg: Königshausen \& Neumann, 2001) 97-104.

Sennett, Robert S. Hollywood Hoopla: Creating Stars and Selling Movies in the Golden Age of Hollywood (New York: Billboard Books, 1998).

Server, Lee. Ava Gardner: “Love is Nothing” (New York: St. Martin's, 2006).

Singer, Kurt. "Oikonomia: An Inquiry into Beginnings of Economic Thought and Language," Kyklos 11 (1958) 29-57.

Spahn, Peter. "Oikos und Polis. Beobachtungen zum Prozeß der Polisbildung bei Hesiod, Solon und Aischylos," Historische Zeitschrift 231 (1980) 529-564.

Sussman, Linda S. "Workers and Drones, Labor, Idleness and Gender Definition in Hesiod's Beehive," Arethusa 11 (1978) 27-41.

Török, Jean-Paul. "Eva Prima Pandora," L'Avant-scène du Cinéma 245 (1980) 4-5.

Vernant, Jean-Pierre. "The Myth of Prometheus in Hesiod," in idem, Myth and Society in Ancient Greece (trans. Janet Lloyd; New Jersey: Humanities Press, 1980) 168-185.

Wagner, Ferdinand. Das Bild der frühen Ökonomie (Salzburg: Stifterbibliothek, 1969).

Wagner, Richard. Sämtliche Werke, vol. 4: Der fliegende Holländer: Romantische Oper in drei Aufzügen, ed. by Egon Voss (Mainz: Schott, 2001).

Wedekind, Frank. Der Erdgeist, in Lulu. Erdgeist. Die Büchse der Pandora (ed. Erhard Weidl; Stuttgart: Reclam, 1989).

Weigel, Sigrid, "Die geopferte Heldin und das Opfer als Heldin: Zum Entwurf weiblicher Helden in der Literatur von Männern und Frauen," in Inge Stephan and Sigrid Weigel, Die verborgene Frau: Sechs Beiträge zu einer feministischen Literaturwissenschaft, (3rd ed.; Hamburg: Argument, 1988) 138-152.

Wind, Edgar, "The Revival of Origen," in Studies in Art and Literature for Belle da Costa Greene (ed. Dorothy Miner; Princeton: Princeton University Press, 1954) 412-424.

Zeitlin, Froma I. "The Economics of Hesiod's Pandora," in Ellen D. Reeder, ed., Pandora: Women in Classical Greece (Princeton: Princeton University Press, 1995) 49-56.

_ . "Signifying Difference: The Myth of Pandora," in Richard Hawley and Barbara Levick, ed., Women in Antiquity: New Assessments (London: Routledge, 1995) 59-74. 



\title{
PHRYNE PAVES THE WAY FOR THE WIRTSCHAFTSWUNDER: VISIONS OF GUILT AND "PURITY" FED BY ANCIENT GREECE, CHRISTIAN NARRATIVE, AND CONTEMPORARY HISTORY
}

\author{
Barbara Schrödl
}

Parallel to the founding of Federal Republic of Germany in May 1949, West Germany was on the lookout for new sources of national self-esteem. The concept of a "nation of culture" was a suggestion from intellectual circles, and one which met with broad acceptance until the beginning of the Wirtschaftswunder ("economic miracle") in the mid-1950s. In a country which had been forced into unconditional capitulation, whose economic system had collapsed, and whose political order had disintegrated, culture had very few rivals. The notion of the Kulturnation depended on aspects of not only recognized high culture but also contemporary art. Particular attention was devoted to classical antiquity, Christian motifs, and modern aesthetics. This was especially true for the fine arts. References to the immediate Nazi past were employed in parallel with the Passion or ancient statues of gods, as we see in Otto Dix's "Ecce Home" or Gerhard Marks' sculpture, "Gefesselter Prometheus." Classical or Christian themes often appeared in an explicitly "modern" form as a way of bringing up to date a past which, with the general social consensus being to avoid allusions to actual historical events, had taken on a character of eternal validity, though not one which was entirely divorced from history. This was repeatedly integrated into the context of individual and collective identity constructs, and in this cinema played a significant role. The apparently apolitical entertainment film proved to be a suitable medium of communication about the nationalist socialist past, contemporary events, and future developments. Traditionally, cinema is regarded as an interface between the individual psyche and social discourse. Popular films take up the longings and fears of a wide audience and lend them a specific aesthetic form which in turn informs the audience's imagination and ideas. As Stephan Lowry argues, film, the individual, a nd society all shape each other. In the period after the Second World War, the task at hand was to

1 Otto Dix, "Ecce Home II mit Selbstbildnis hinter Stacheldraht (Ecco Homo II)" (1948) or Gerhard Marks, "Gefesselter Prometheus” (1948/50). 
restructure the political system, the economy, and society, and to integrate the individual into this new community. Cinema became important in this context.

The film Die Sünderin (The Sinner, 1951) by Willi Forst provides a good example of cinema's role in the post-war period. I argue that the film creates a complex web which, while pointing to the future, alludes to classical antiquity, Christian narrative, and National Socialism to make the death of a woman in the contemporary present interpretable as a sacrifice legitimated by the cultural tradition and required for the creation of a new state community unencumbered by the legacy of the past.

The film tells the story of the love between a male artist and his female model, a motif which has a long tradition in what we might call "artist myths." Ernst Kris and Otto Kurz find its beginnings already in ancient narratives, as in those relating that the woman depicted in some of the works of the early fourth-century Athenian sculptor Praxiteles was the artist's mistress. ${ }^{2}$ Breaking out of this tradition, however, the focus here is not on the artist but the model, who through her relationship with the painter is elevated from a prostitute into a loving and self-sacrificing partner, who eventually helps the terminally ill artist to end his life and then takes her own. Through a convoluted flashback structure, the story is told back to front, so that the film begins and ends with the death of the painter and the model. Two conflicting patterns of interpretation are suggested. Seen as the story of a relationship, the film tells of the failure of a great love. In the death scenes, the images signalize deep intimacy while the plot is driven by betrayal and loneliness. The painter believes that his lover has a great future before her, but she secretly follows him into death. Seen as an art film, on the other hand, the outlook is much more hopeful. The death of the pair is underscored by a slow fade-out, but then the final frame shows a close-up of a female nude entitled "Phryne." Completed just before the death of the lovers, the painting represents both the painter's magnum opus and the pinnacle of the collaboration between the painter and the model. The scene is slowly illuminated until the painting is resplendent in bright light. A new day seems to have dawned. This use of lighting suggests to the audience that the work is a masterpiece, and encourages the belief that both painter and model will live on in art history.

2 Ernst Kris and Otto Kurz, Die Legende vom Künstler: Ein geschichtlicher Versuch, (Frankfurt am Main: Suhrkamp Verlag, 1980) 148-150. The volume was published the first time in 1934 in Wiener Krystall Verlag. 
"Phryne" depicts a female nude reclining in a wide landscape containing a classical temple. The figure takes up most of the canvas. The upright upper body is painted face on, while the lower body, with legs bent, is depicted from the side. The head is turned towards the observer, but the eyes are lowered, prohibiting eye contact. The description signalizes both timelessness and a rootedness in time. While the idealized nudity and classical background allude to an idealized place, the figure's waved blonde hair smacks of contemporary fashion. This tension transforms the human into what appears to be eternal. In art-historical terms, the painting belongs to the tradition of the reclining Venus. Venus, who in ancient Rome was identified with the Greek goddess Aphrodite, has been a favourite motif in art since the Renaissance. In the picture in question and especially in the way it is presented during the death scene in the film, the body is clearly outlined so as to stand out from the background, and the almost sculptural painting technique lends it a particular physicality. The body appears as a clearly outlined unity. What is drawn is an anatomically correct picture of physical beauty. The artistic language is akin to photography. A photograph appears to have been translated to a large format oil painting, which in turn takes on monumental dimensions as it shines forth from the cinema screen. This is reminiscent of Nazi art. Nationalist Socialist painting can be described in the words of Berthold Hinz as an amalgamation of naturalistic and idealistic tendencies, which are "simplified, smoothed and harmonized" by means of the New Realism. ${ }^{3}$ The painting "Phryne" is also indebted to Naturalism, Idealism, and New Realism. A "clean" nudity is staged here, one that resembles the Nazi ideal of "Aryan" beauty. "Phryne" does not just recall Nazi art through the lens of art history but almost certainly triggered the same associations in the contemporary cinema audience. Even those who had never shown a special interest in the visual arts were likely still to be familiar with examples of Nationalist Socialist art around 1950, as Nazi art propaganda had, by turning "high art" into mass culture, reached an incredibly wide audience.

In the film, however, "Phryne" is not created in the Nazi period but in the present. The nude takes the audience out of the postwar period, into the Nazi past, and back into the present. Die Sünderin thus celebrates as a contemporary masterpiece a painting which, from the perspectives of art

\footnotetext{
3 Berthold Hinz, “'Entartete Kunst' und 'Kunst im Dritten Reich,' Eine Synopse," in Kunst und Macht im Europa der Diktotoren 1930 bis 1945 (Berlin: Oktogon-Verlag, 1996) 330-333, here 331 .
} 
history, the audience, and the logic of the film, is connected with National Socialism. I would like to examine this surprising observation in more depth and to consider what effect the recourse to ancient Greek references may have had in this context.

Portrayals of visual artists are not a rarity in cinematic history, and in the German cinema of the postwar period they were all the rage. In the 1950s, the tension between modern art and tradition became increasingly important in this context. The question of whether art should be traditional and representational or modern and abstract took on deep significance. The representational artist was usually portrayed as a positive figure, the abstract artist as a negative one. In some films the representational and the abstract artist were, as the result of the illness narrated by the film, one and the same person. This is the case in Die Sünderin. Phases of illness connected with the production of abstract pictures alternate with phases of health in which representational art, including the masterpiece "Phryne," is produced.

Interestingly, the positive portrayal of representationality in cinema was actually at odds with the high cultural discourse of the time. In exhibitions, art criticism, and academic art history post-1945, a demonstrative rehabilitation had taken place of the "modern" art that had been defamed by the Nazis. Although the high cultural and the popular art discourse were poles apart, both relayed, in their juxtaposition of modern art and traditional representationality, a pattern of argument which had already determined Nazi art policy. Two complementary exhibitions held in Munich in 1937, the Große Deutsche Kunstausstellung and the exhibition Entartete Kunst, provide a typical example of Nazi propaganda. The collapse of National Socialism may have cost the Nazi understanding of art its legitimation, but it had not necessarily robbed it of its power.

The film under discussion, for instance, is heavily influenced by the Nazi view of art. Not only is the work of the painter Alexander Klaes 4 reminiscent of New German Art (neue deutsche Kunst), but the paintings produced during his phases of ill health are suggestive of modern art, one example of which is an abstract landscape described as having "gone wrong." The artist suffers from a brain tumor which will lead to blindness and death. It is not hard to imagine that a painter whose center of vision is being eaten away by a tumor is one on the way to losing his creative prowess. In the film, it is an art dealer who articulates this growing sense

4 Alexander Klaes depicts himself as a fictious artist. The character seems not to be based on a specific model. 
amongst the audience, describing Klaes as "an artist with eye problems and impaired vision." This recalls a prominent speech by Hitler against modern art: 5

I do not intend to enter into an argument about whether those concerned really do see and feel things in this particular way. In the name of the German people, I simply want to forbid the pitiful unfortunates who clearly suffer from diseased vision from attempting to force the products of their misobservations upon the world and from attempting to pass them off as reality or even as "art."

The possible causes of the "defects of the eye" suffered by "modern" artists are proposed in this speech to be either heredity or mechanical influences. Soon afterwards, Nazi defamation of modern art became entirely focussed on the heredity theory. Although Sünderin links the artistic discourse with the medical discourse, the film stays noticeably away from the idea, still firmly associated with National Socialism, of the hereditary insanity of the modern artist. Instead it takes up the notion - fashionable in the postwar discourse, which had clearly distanced itself from racist thinking and social exclusion - of a link between illness and culture. Although the isolated theoreticians who continued to reject modern art, like Hans Sedlmayr, argued that contemporary culture was an illness of which modern art was a symptom, most artists, including Willi Baumeister, and theoreticians, like Hilla Rebay, went so far as to claim that modern art had a soothing or even healing effect on the souls of their contemporaries. ${ }^{6}$

The film, then, does not just regurgitate Nazi paradigms but reacts as well to contemporary debates. This is problematic, however, as the juxta-

5 Adolf Hitler's speech at the opening of the "Haus der deutschen Kunst" in July, 1937 in Munich. For the text, see Herschel B. Chipp, ed., Theories of Modern Art: A Source Book by Artists and Critics (Berkeley: University of California Press, 1968) 474-483. Cf. Jonathan Harris, Writing Back to Modern Art: After Greenberg, Fried, and Clark (London: Routledge, 2005) 161 and 242.

6 On Sedlmayr and Baumeister, see: Hans Gerhard Evers, ed., Das Menschenbild in unserer Zeit (Darmstadt: Neue Darmstädter Verlagsanstalt, 1951); Axel Schildt, Ankunft im Westen. Ein Essay zur Erfolgsgeschichte der Bundesrepublik (Frankfurt am Main: S. Fischer, 1999) 158; and Beat Wyss, "Willi Baumeister und die Kunsttheorie der Nachkriegszeit," in Gerda Breuer, ed., Die Zähmung der Avantgarde: zur Rezeption der Moderne in den $50^{\text {er }}$ Jahren (Basel and Frankfurt am Main: Stroemfeld, 1997) 55-71. On Rebay, see: Katja von der Bey, "Maler und Hausputz im deutschen Wirtschaftswunder: Künstlermythen der Nachkriegszeit zwischen 'Kulturnation' und Wirtschaftsnation", in Kathrin Hoffmann-Curtius and Silke Wenk, eds., Mythen von Autorschaft und Weiblichkeit im 20. Jahrhundert (Marburg: Jonas-Verlag, 1997) 234-244; and Katja von der Bey, Nationale Codierung abstrakter Malerei: Kunstdiskurs und -ausstellungen im westlichen Nachkriegsdeutschland 1945-52 (PhD diss., University of Oldenburg, 1997) 112-145. 
position of "negative" (within the context of the film) works that incorporate aspects of postwar art and "positive" works which belong to the New German Art tradition lends new topicality to Nazi ideas. The question is in what way. If one examines the high cultural discourse of the time, it becomes clear that in the field of art, questions were being discussed whose significance went beyond the purely artistic. Contemporary tendencies towards abstraction and the intense exploration of the creative media themselves were understood as a cleansing of art of extra-artistic impulses. The "pure modern art" which resulted, however, was in turn interpreted politically and deemed to have a cleansing effect in relation to National Socialism. This labored quest for "purity" may have been born of honest democratic intentions, but it still demonstrates an involuntary attachment to the past, as notions of hygiene had constituted one of the basic pillars of Nazi art policy, the aim of which, famously, had been "(racially) pure art" ((art)reine Kunst). Seen from this perspective, Sünderin may have revealed and drawn attention to inconsistencies in the high cultural debate.

This is not to say that the plot in itself was received as an unproblematic piece of fiction. Die Sünderin caused a scandal when it was released, though audiences were less shocked by the questions it may have raised about the visual arts than by the fact that in one scene, where she poses as a model, the female lead, played by Hildegard Knef, appears completely naked. Intense debate ensued amongst religious, political, and cultural representatives as to the sexual integrity of both the character and the actress. This is interesting, as the film tackles a number of topics which were taboo in the 1950s, including suicide, euthanasia, and the Nazi past, none of these caused as much outrage as the model scene.

Let us examine it in more detail. Long shots direct the audience's attention less to the characters themselves and their emotions than to the constellations of characters and the spatial context. We see a man and a naked woman in an idyllic garden. Automatic associations with Paradise are reinforced by Marina's voiceover:

I was lying in the grass hidden from view by a large parasol. You said it was unnecessary, because only the guilty have anything to hide, and to you I was pure.

The picture that results is the masterpiece "Phryne." The title refers to the famous Athenian hetaera of the fourth century BC who was renowned for 
her extraordinary beauty. ${ }^{7}$ She was often portrayed as Aphrodite. ${ }^{8}$ She was not just beautiful, but provocatively independent, a combination which eventually led to her being accused of holding orgiastic processions. She was acquitted on the merits of a celebrated speech which has, unfortunately, not been preserved. According to legend, however, Phryne was accused of ungodliness for having claimed that her own beauty rivalled that of a goddess. In order to prove her innocence, it is said that she tore off her robe (or had it torn off) and was thus acquitted. The legend was a frequent motif in nineteenth-century art, which led to its becoming fairly widely known. Some portrayals of Phryne are deemed to be "masterpieces" of art history, and the film's audience is likely to have been familiar with them. ${ }^{9}$ The references to classical antiquity and the art historical tradition lend the legitimacy of an accepted cultural concept to the notion that a complex entanglement of guilt and innocence may eventually lead to purity. The chain of association linking nakedness, guilt, and purity is played out on the plot level of the film: Marina is transformed from a prostitute to a kind of saint.

What is interesting is that the vision of purity conveyed by the nude model scene is one from which the audience is excluded. Only in the opening sequences of the scene do the dominant figures of identification invite the audience to imagine itself as "pure." On the visual level, viewers are invited to share the perspective of the painter, while the acoustic level calls for identification with the model. Both of these are positions of professionalism. Initially, then, the audience is party to a process which in the high cultural art discourse was deemed to be worthy of aspiration even at the turn of the twentieth century, where the gaze of the artist, which sees the work of art into which the model can be transformed, is contrasted with the gaze of the layman, who sees only the desirable woman. When, however, in the film, two men climb over the garden wall, the audience is made aware, through the presence of the outsiders, of its voyeuristic position, realizing that it shares the voyeuristic "layman's" gaze and remains trapped in a position of guilt.

7 As in, Uwe Walter, "Phryne," Der neue Pauly 9 (2000) 969.

8 Perhaps by Praxiteles as the model for his Aphrodite of Knidos, e.g., Christine Mitchell Havelock, The Aphrodite of Knidos and Her Successors: A Historical Review of the Female Nude in Greek Art (Ann Arbor: University of Michigan Press, 2007) 48.

9 E.g. Joseph Mallord William Turner's "Phryne Going to the Public Baths as Venus Demosthenes Taunted by Aeschines" (1838), and Jean-Léon Gérôme's "Phryne Revealed Before the Areopagus" (1861). 
In my opinion, the reason that the moral questions which the nude model scene touched upon were so provocative is that depictions of female nudity were supposed to be metaphorical. Nudes as depictions of femininity traditionally function, as Silke Wenk argues, as pictures of community. This notion was articulated in a racist fashion under the Nazis. Upright female nudes represented the healthy and sound body politic (Volkskörper). ${ }^{10}$ There was nothing guilt-worthy about the sight of this kind of body: it was displayed demonstratively and a show made of its showing. After the collapse of National Socialism, the body politic was no longer acceptable as a model of interpretation for images of femininity. The film highlights the fact that the displaying of female nudity has once again become problematic. The reference to the "body politic," however, is not erased but brought up to date. The quest to find a pure way of looking at a naked model or female nude, the subtext of numerous films of the 1950s, appears to have been intended to encourage associations with the foundation of the Federal Republic of Germany. If images of female nudity were not read as pictures of naked women but representations of the new community, films like Die Sünderin could explore pressing questions relating to that community. The displaying of female nudity constituted an offer to communicate on the subject of national guilt and innocence.

In the film under discussion, the reference to ancient Greece is of particular relevance in this context. Interest in antiquity is traditionally associated with the educational aspirations of the middle classes and can signalize an affinity with middle-class traditions. It had been used in this way during National Socialism to win over the conservative middle classes. Die Sünderin, however, a post-war film, draws on antiquity in a way which seems to be intended to distract from the Nazi past. The allusion to Phryne and the legend of the proving of her innocence might have worked as a kind of immunization of the audience against questions regarding the historical events of the Nazi past. Complex entanglements of guilt and purity are presented as phenomena which have occurred throughout time. A biblical reference to Paradise underlines this further, and, additionally, introduces the idea of salvation. At the end of the film, the model is replaced by the work of art. Marina seems to have been resurrected in art. The resurrection fantasy banishes guilt to the past: the sinner on earth is subsumed by an image of purity, an image which can stand for the community. The death of the model can thus be interpreted

10 Consider as the several female nudes by Fritz Klimsch. 
as a sacrifice made in the name of a new beginning, a fresh start unencumbered by the burden of guilt carried over from the Nazi past.

Notions of sacrifice also have a long tradition in art history, with artists often portrayed as having "sacrificed" their life to art. Over the course of history, the notion of sacrifice has been used repeatedly to link the artistic discourse with the political. In the Third Reich, the idea of the artist sacrificing his life to art was reframed to show the artist placing both his art and his life at the service of the "people's community" (Volksgemeinschaft). Die Sünderin offers a new version of the art historical sacrifice myth. This time, the sacrificial victim is the female model.

Female "sacrifices" were a topical subject in the post-war period even outside the cinema. During the war, women had managed the day-to-day running of life on the home front more or less alone and thus acquired a new position of strength. After the war, the focus shifted onto reintegrating into civilian life the men returning from prison camps and the fronts. Returning soldiers were often physically weak and mentally damaged. The discrepancy between this reality and the established picture of the military hero could not have been greater. Moreover, the Nazi ideal of soldierly masculinity must, after Germany's total defeat, have appeared to be just as obsolete as the gender-coded representation of the Third Reich. Both individual and collective identity constructs, then, were in need of redefinition. In this context, narratives featuring a male artist hero, his female model, and the fruits of his artistic vision worked particularly well. They can be read as a proposal not to give up the notion of the male hero all together, but to replace the military hero, whose job was to protect the (in terms of its portrayal at least) feminine community by force of arms, with an artist hero whose art promises to bring about a new, unencumbered beginning. In retrospect it seems problematic that films like Die Sünderin should demand a female sacrifice, and that female figures should be relegated to the role of model while men are feted as great artists. It is also impossible not to be critical of the way in which ancient Greece is portrayed as a tradition with eternal validity and used to bolster the restoration, via the instrument of myth, of established middle-class gender constructs in post-war Germany.

\section{Works Cited}

Breuer, Gerda, ed. Die Zähmung der Avantgarde: zur Rezeption der Moderne in den $50^{\text {er }}$ Jahren (Basel and Frankfurt am Main: Stroemfeld, 1997).

Chipp, Herschel B., ed. Theories of Modern Art: A Source Book by Artists and Critics (Berkeley: University of California Press, 1968). 
Evers, Hans Gerhard, ed. Das Menschenbild in unserer Zeit (Darmstadt: Neue Darmstädter Verlagsanstalt, 1951).

Harris, Jonathan. Writing Back to Modern Art: After Greenberg, Fried, and Clark (London: Routledge, 2005).

Havelock, Christine Mitchell. The Aphrodite of Knidos and Her Successors: A Historical Review of the Female Nude in Greek Art (Ann Arbor: University of Michigan Press, 2007).

Hinz, Berthold. "Entartete Kunst' und 'Kunst im Dritten Reich.' Eine Synopse," in Kunst und Macht im Europa der Diktotoren 1930 bis 1945 (Berlin: Oktogon-Verlag, 1996) 330-333.

Kris, Ernst and Otto Kurz. Die Legende vom Künstler: Ein geschichtlicher Versuch, (Frankfurt am Main: Suhrkamp Verlag, 1980).

Schildt, Axel. Ankunft im Westen. Ein Essay zur Erfolgsgeschichte der Bundesrepublik, (Frankfurt am Main: S. Fischer, 1999).

von der Bey, Katja. "Maler und Hausputz im deutschen Wirtschaftswunder: Künstlermythen der Nachkriegszeit zwischen 'Kulturnation' und Wirtschaftsnation," in Kathrin Hoffmann-Curtius and Silke Wenk, eds., Mythen von Autorschaft und Weiblichkeit im 20. Jahrhundert (Marburg: Jonas-Verlag, 1997) 234-244.

von der Bey, Katja, Nationale Codierung abstrakter Malerei: Kunstdiskurs und -ausstellungen im westlichen Nachkriegsdeutschland 1945-52 (PhD diss., University of Oldenburg, 1997).

Walter, Uwe. "Phryne," Der neue Pauly 9 (2000).

Wyss, Beat. "Willi Baumeister und die Kunsttheorie der Nachkriegszeit," in Gerda Breuer, ed., Die Zähmung der Avantgarde: zur Rezeption der Moderne in den 5oer Jahren (Basel and Frankfurt am Main: 1997) 55-71. 


\title{
THE NEW ISRAELI FILM BERURIAH: \\ BETWEEN RASHI AND TALMUD, BETWEEN ANTIQUITY AND MODERNITY, BETWEEN FEMINISM AND RELIGION
}

\author{
Tal Ilan
}

This short study, embedded in this book resulting from a conference devoted to gender, politics, and antiquity in cinema, stands at the intersection of no fewer than four of my research interests. The first is antiquity, particularly the postbiblical or Greco-Roman period, and its impact on the Jews. The second is gender, particularly Jewish women and gender in antiquity. ${ }^{1}$ The third is Beruriah. Women studies requires that we identify women role models and inquire what they had done in the past, how they functioned within a world where the feminine was stereotyped and her position in society dictated by men, and how within these limitation, they achieved recognition and influenced the world they lived in. Beruriah was such a woman. In the Talmud, the book which the Jews hold sacred second only to the Bible, a book that recounts the deeds and words of hundreds of male scholars, Beruriah is the only woman represented as wise and learned, and who also left a mark on the past. In 1999 I published a chapter in Integrating Women into Second Temple History devoted to Beruriah and her literary history. ${ }^{2}$ That study lies at the heart of this paper.

The fourth, cinema, connects and focuses all three. Films tell good stories, are often politically independent, are often shot on location in the land, and also, by a careful close reading, can serve as excellent tools for research and critique of the culture they represent. The following is an attempt at an innovative reading of an ancient text, intended to make it

\footnotetext{
1 Originally, Tal Ilan, Jewish Women in Greco-Roman Palestine: An Inquiry into Image and Status (Tübingen: Mohr Siebeck, 1995). Now I direct a research project devoted to producing a feminist commentary on the Babylonian Talmud; see Ilan, Tamara Or, Dorothea M. Saltzer, Christiane Steuer and Irina Wandrey, eds., A Feminist Commentary to the Babylonian Talmud: Introduction and Studies (Tübingen: Mohr Siebeck, 2007); Tal Ilan, $A$ Feminist Commentary to the Babylonian Talmud, Volume II.g: Massekhet Ta'anit (Tübingen: Mohr Siebeck, 2008).

2 Tal Ilan, "Beruriah Has Spoken Well (tKelim Bava Metzia 1:6): The Historical Beruriah and Her Transformation in the Rabbinic Corpora," in Integrating Women into Second Temple History (Tübingen: Mohr Siebeck, 1999) 175-94.
} 
understood and relevant for the modern viewer. ${ }^{3}$ The innovate reading is that of Beruriah (2009) a new Israeli film directed by Avraham Kushnir, written by Baruch Brenner, Hadar Galron, Yuval Cohen, and Kushnir, and paralleling the story of the ancient Beruriah. ${ }^{4}$

At the outset it is important to point out that although the Jews have a long history, Israeli cinema seldom touches on it. Israeli cinema is often self-centered and contemporary. We seldom find films which, when referring to the past, take place even five or ten years ago, let alone further in the past. ${ }^{5}$ Indeed, even films made based on books written in the past are often brought forward to represent the immediate present. ${ }^{6}$ One reason for this is, I suspect, very practical. Films retelling the past require a meticulous reconstruction of the spaces in which they took place, of the clothes people wore, of the modes of transportation used, even of the language that had once been spoken. These not only require thorough research but also a substantial budget. Israeli cinema is basically a low-budget cinema. The film about Beruriah is also a low-budget film, and it also takes place in the present. Yet, even though it occurs in the present, it is based squarely on the story of the talmudic Beruriah. Let us then begin with this story.

\section{The Talmudic Beruriah}

In an article published in 1991, Rachel Adler wrote the following summary of the story of Beruriah derived from all the available references. I use her

3 For the initiated talmudist, I would call it a new midrash.

4 The title is also transliterated as Bruriah.

5 See, for example, the recent collection of articles that treat specifically historical memory, Raz Yosef, ed., "History and Memory in Israeli Cinema," in Israel: Studies in Zionism and the State of Israel 14 (2008) (Hebrew) where the films discussed, which are supposed to represent memory, all relate to very recent memory. In the introduction (2-8) Yosef discusses "Waltz with Bashir," an animated film produced in 2008 and taking place in 2008 with flashbacks to the events of 1982. In Sandra Meiri's article, "Memory, Trauma and Ethics in Judd Ne'eman's Feature Films," (32-69), she discusses films that deal with Jewish memory, but take place between 1983 and 1989, when they were produced. In the article by Raya Morag, "Sound, Image and forms of Remembrance: Israeli narrative Cinema during the Second Intifada," (71-88) she discusses films made in 2004-2005 about events that had taken place in the years 2000-2003, etc.

6 See, for example, the film made based on Dan Ben Amotz's book לא שם זין Does not Give a Damn) in 1987. The original book was written about the endless skirmishes between the Israelis and Egyptians on the Suez Canal between 1967 and 1973 on the Egyptian front, but was moved by the scriptwriter (Shmuel Imberman) to the Lebanon war which raged between Israel and Lebanon as of 1982 for 20 years. 
description because I think she rightly sensed the power of this story, and, at the same time, that it is only a story: ${ }^{7}$

Once there was a woman named Beruriah, and she was a great talmudic scholar. She was the daughter of the great Palestinian rabbi Hananya ben Teradyon, who was martyred by the Romans (1). Even as a young girl she far outstripped her brother as a scholar (2). It was said she had learned three hundred laws from three hundred teachers in one day (3). She married Rabbi Meir, the miracle worker and great Mishnaic sage. One time, when Rabbi Meir prayed for some robbers to die, Beruriah taught him to pray that their sin would die, that they repent (4). She also taught Meir resignation when their two sons died (5). Loving and gentle as she was with Meir, Beruriah could also be arrogant and biting. She ridiculed a Sadducee (4), derided an erring student and made a fool of Yose the Galilean when he met her on the road (6). Finally, she mocked the sages' dictum that women are easily seduced, and she came to a shameful end. Rabbi Meir set one of his students to seduce her. After long denial she yielded to him. When the plot was revealed, she strangled herself, and Rabbi Meir fled to Babylonia, because of the disgrace (7).

What this story, as told by Adler, fails to do is alert the reader that a complete version is found nowhere in the sources. It is a narrative stitched together from various separate episodes, told by various scholars in various periods over time, beginning almost in the days of Beruriah herself, in the second century and ending with what the eleventh-century French talmudic commentator Rashi added to it. In my study of Beruriah, I attempted to conduct an archaeological excavation into the story, removing one narrative layer after the other, in order to try to arrive at its historical kernel. I will here summarize as briefly as possible the results of my study. I claimed that in the earliest layer of the Beruriah story, recorded in a text known as the Tosefta, she is presented, like all other sages in the academy, as making a statement pertaining to Jewish law (tKelim Bava Metzia 1:6). The Tosefta, however, never attained canonical status in Judaism. In fact, it contains many traditions that were intentionally rejected by the authoritative text of the Mishnah. The statement Beruriah makes in the Tosefta is one such tradition. I was able to show that Beruriah's teaching was considered sound, and thus the Mishnah presents it, transforming it into the opinion of a male sage (mKelim 11:4), effectively silencing Beruriah.

\footnotetext{
7 Rachel Adler, "The Virgin in the Brothel and Other Anomalies: Character and Context in the Legend of Beruriah," Tikkun 3/6 (1988) 28, referring to (1) bAvodah Zarah 18b; (2) tKelim Bava Qama 4:17; (3) bPesahim 62b; (4) bBerakhot 10a; (5) Midrash Mishlei 31; (6) bEruvin 53a; (7) Rashi to bAvodah Zarah 18b.
} 
Next, the Babylonian Talmud takes issue with this woman. I think the Babylonians knew about Beruriah because, although the Mishnah attempted to write her out of its law-code, the scholars in Babylonia knew most of the traditions found in the Tosefta. Although they never refer to Beruriah's specific ruling, they tell numerous episodes about her, making her exceedingly wise, and supplying her with a noteworthy pedigree and husband (e.g. bPesahim 62b). I explained this interest of the Babylonians as academic. They knew about a woman who had contributed neutrally to rabbinic discourse and inquired as to who she could have been. I have conducted a similar exercise in numerous classes, and my students have always come up with the same answers. For Beruriah to succeed she must meet two prerequisites: she should actually be wiser than most of the men around her, which by itself would still not be enough; and she has to come from a supportive family of sages, who would encourage her budding academic interests. In their own way, this is what the Babylonians did for Beruriah. This is how she acquired a father and a husband who were Torah scholars.

The last layer is the story Rashi tells about Beruriah. Interpreting an enigmatic expression about her mentioned in the Talmud, ma'aseh deberuriah (the event/story of Beruriah), ${ }^{8}$ he relates the story of Rabbi Meir's plot against her, her seduction by his student, her suicide, and Meir's flight. In my study of Beruriah I had claimed that Rashi told this story because for him the Babylonian Beruriah was too powerful and perfect. He felt that a perfect female Torah scholar was simply excessive. She had to be destroyed both academically and physically, and this is what he did. His near canonical status as the most important talmudic commentator has made his conclusion an integral part of how the story of Beruriah is told.

\section{The Cinematic Beruriah}

The film Beruriah, not surprisingly, hinges completely on this last episode. After all, without it there is no story, and a film, like theater, needs drama and, if possible, tragedy, and this is what Rashi provided for the story of Beruriah. The script writers say as much when they place in the mouth of one of their protagonists the words:

There is everything in this story: betrayal, death, God, sex.

8 For my interpretation of this expression see Ilan, "Beruriah has spoken well," 190-91. 
Here follows the plot of the film. In the orthodox community in Jerusalem lives a man who had once written a book about the talmudic Beruriah. This book had been so controversial that the leaders of his community excommunicated him and burnt all the copies of his book. Thirty years hence, he lives in solitude in orthodox Jerusalem, with only his daughter, whom he had aptly named Beruriah, for support. She is married to Jacob (aptly surnamed Ben-Meir) and is the mother of two daughters and a son. Obviously, orthodox Jerusalem had not looked favorably on such a match, and Jacob's father, who had been one of the rabbis active in the excommunication of Beruriah's father, has now disowned his son, and Beruriah and Jacob have moved into a neo-orthodox Jewish environment in Jerusalem.

Beruriah, herself a highly educated woman, is forever obsessed with her father's book, which she has never read, because there are no copies of it left, and her boss at an antiquarian bookshop in which she works employs the services of Joseph, a new teacher in the school where her husband works, and a one time journalist, to search for possible copies of the book that had escaped the conflagration. At the same time Joseph invites him to his house to participate in a study session dedicated to Rashi's commentary to the Beruriah story. Beruriah, who is not seated at the table with her husband's colleagues, but who is ever present and listening, challenges the men's claims about this story, which in effect repeats Rashi's construction of the talmudic Beruriah's mockery of women's light-minded nature. In so many words, Beruriah's husband now adds to his colleague's mission also the task of seducing Beruriah. At the end of the film, the book is found in Beruriah's father-in-law's house, and some sort of seduction takes place; but which? The film slides into a surrealistic sequence of pictures and fails to answer the question with clarity.

Now I begin my analysis, which is an intertextual reading of this film with its sources, assumptions, and innovations.

\section{Book-Burning}

The film begins with a very powerful image of fire and the destruction of Hebrew books. These images repeat themselves throughout the film. The burning of anything written in Hebrew raises in the viewer a host of collective memories from the burnings of the Talmud at various occasions in medieval Europe down to the burning of Jewish (and other) books in Bebel-Platz in Berlin some seventy years ago. The irony of this scene in 
this film is that here it is Jews who are burning the books, and they are burning the book of one of their fellows. That the film-makers were aware of this irony is obvious from the way this book burning is described by an eyewitness, a secular Israeli photographer played by Alex Levak, who won the Israel Prize for photography in 2005 (portraying himself in the film). He says: ${ }^{9}$

Look, Jews burning books. Think about it; its completely insane. Our people suffered so much. They burnt our books, they burnt us alive. Suddenly we are burning books?

What few people - apparently not including even the filmmakers - know is that the first powerful description of Jewish book-burning is found in the Babylonian Talmud directly associated with the martyrdom of Hananiah ben Tardion, the person the Talmud identifies as Beruriah's father. In bAvodah Zarah (18a) we learn that at a time when the Roman authorities forbad the Jews to study their sacred texts, Hananiah ben Tradion was discovered preaching with a scroll of Torah in his lap. He was sentenced to be burned to death along with his scroll, and while burning, his students asked him what he saw. He answered: "I see the parchment burning, but the letters fly into the air," namely, that it is only the material scroll on which the holy words are written that can be destroyed and not the words themselves. In this context I cannot help but quote Mikhail Bulgakov's memorable saying that he puts in the mouth of the devil himself in his The Master and Margarita: "Manuscripts cannot burn." This sentence has been used by dissidents the world over when their words were being silenced. We have to assume that the screenwriters had this interpretation in mind when they wrote the script of the film.

When Beruriah first meets Joseph, her husband's colleague who will later seduce her, it is at the location in the forest, just outside Jerusalem, where this book-burning had once taken place. This location is called Givat Hananiah, after the talmudic Beruriah's father, for it is also traditionally identified as the site of Hananiah ben Tardion's execution. When they meet, Joseph says to Beruriah:

Many years ago, about thirty years, they burnt a book. Here.

To this she responds:

9 Translation taken from the subtitles of the DVD release of the film. 
Do you know what happened here 1900 years ago?... There was a little girl, about eight years old. She hid among the bushes. She watched the Romans leading her father to his death. Tying twigs to his body, and lighting the fire.

In its own way, this description also has a talmudic foundation. Just before the aforementioned passage in which his students asked him, while burning, what he saw, the Talmud (bAvodah Zarah 18a) reads:

[The Romans] brought him out, rolled him in the Torah scroll and twigs and put fire to them.... His daughter said to him: "Father, how can I see you so?" He said to her: "If it were only me burning I too would suffer, but now that the Torah is burning with me, whoever seeks revenge for the desecration of the Torah will also seek my revenge."

But of course in the film, although the contemporary Beruriah is talking of the talmudic Beruriah, she sees in her mind's eye herself, thirty years earlier, for she continues:

And the little girl took a deep breath and started running from there down this path. She paved her way through the crowd, and she reached the top so that she could see with her own eyes how her father goes up in flames to sanctify the name of God. You know the girl's name?

To which Joseph answers:

Beruriah. Pleased to meet you. I am Joseph.

The film thus suggests here a neat reversal of Heinrich Heine's famous dictum: "This was just a prelude: where books have been burned, one day people will burn."10

\section{The Rashi Episode}

The book Beruriah's father had written and the rabbinic authorities burned lies at the heart of the film. The plot is essentially a quest for the lost book, and it comes to an end when the book is found. However, in order for this to happen, Rashi's Beruriah story has to be reenacted. This happens through a repeated retelling of the story. The first person who tells it is Emanuel (Halprin), an Israeli journalist and self-styled actor, acting as someone like himself with the same name. In the film he is the owner

10 Heinrich Heine, Tragödien, nebst einem lyrischen Intermezzo (Berlin: Fredinand Dümmler, 1823) 148. "Dort wo man Bücher verbrennt, verbrennt man auch am Ende Menschen." 
of an antiquarian bookshop (a famous Jerusalem institution on Schatz Street) where, as mentioned above, Beruriah also works. Emanuel tells Joseph Rashi's story as an introduction to the story of the book-burning. Joseph himself is a teacher at a religious school. He is supposed to know the Jewish sources. Together they sit with the Talmud open before them, and Emanuel reads the story out of the Rashi commentary printed on the inner-side of page, as is correct. When he finishes, Joseph is astounded. He says: "I never learned this story." To this Emanuel responds:

This happened before 1900 years. They've hidden it ever since. Except for the few lines Rashi wrote about it. But Rashi was a French winemaker.

If we reconstruct the line of thought behind this statement, the story of a student of Rabbi Meir seducing Beruriah was based on reality. But the affair was suppressed. Only Rashi dared to expose it, and this was because he was a French winemaker, namely a person with a questionable moral character. or perhaps just one whose sexual morals, like those of other Frenchmen, particularly those partial to wine, were lax. This reconstruction is a stereotypical view of either Rashi in particular or Frenchmen in general, or both. It does not explain how, if the story was suppressed, Rashi, who lived only nine hundred, not nineteen hundred, years ago, knew about it. How had the suppressed story survived for a millennium and become known to Rashi so he could pass it on?

The story of Beruriah's seduction is treated again in a scene where Beruriah and her husband are about to go to bed. We see Beruriah reading the Talmud, and then, when they are in bed together, she says to Jacob:

Would you send someone to seduce your wife? Would you be capable of sending someone to seduce me?

Her husband responds by joking but then admits he is jealous of every man she speaks to. It is then that Beruriah says: "That's what Rabbi Meir did to Beruriah." This turns him off. He turns his back to Beruriah saying "Sorry but my name is Jacob." This actually sets the scene for the longest and most complete handling of this episode in the film. When Jacob decides to study this episode together with his study companions (hevruta), he is obviously motivated by his wife's question.

When Jacob announces that they will study this episode, at least one of his colleagues, probably with the knowledge of what is coming, objects and refuses to read aloud. He represents, in the eyes of the filmmakers, the same people who had suppressed this story over the years. He says: 
A story that shouldn't be taught or told. It's terrible. It's a disgrace.

Jacob, however, gives his interpretation to this episode freely:

This happened during the second century. Rabbi Meir, the student of Elisha ben Abbuyah is married to the sharpest, wittiest, smartest woman, Beruriah." She is attracted to the house of study. While the pupils are learning, she listens, corrects, refines, interprets. But Rabbi Meir claims: "You are clever but light minded ... How does Rabbi Meir get into such a predicament?"

One scholar asks Jacob: "Would you send me to seduce your wife?" Beruriah responds to this. She had been lurking in the background all the time in the traditional woman's role, serving at the table, but she had heard everything. She says: “Answer him Jacob, this only a study session.” Jacob turns to Beruriah and asks: "If I did, would you be tempted?" and continues, "Rabbi Meir did it. Maybe out of love? Out of jealousy." Beruriah asks what the scholars at the table think "a light-minded woman" means. The conversation turns into a sharp exchange between husband and wife. Jacob claims that Beruriah can explain this to the men herself. Beruriah says that when she finds out she will tell them. Jacob says Meir had no other choice, but Beruriah would like to know why Meir had not talked to his wife. This is followed by Jacob's most extensive monologue on the issue:

Because he had no choice. What is knowledge? How can a person know something? "And Adam knew his wife Eve." (Genesis 4:1) What? There's wisdom and there is impulse? Are they two separate things? Where does wisdom stop and impulse begin? "And Adam knew his wife Eve." A person without impulses can't know. He can't touch anything. That's what Rabbi Meir understood. The tree of knowledge and the tree of sexual desire, they are branches of the same tree.

And then he turns personal. Pointing at Beruriah he asks:

How can I get inside her and know her? How can I know what she knows? Perhaps that's why Rabbi Meir sent a pupil to seduce you.

11 Elisha ben Abbuyah himself is a colorful figure of rabbinic literature. As much as Beruriah serves as the model woman scholar, Elisha ben Abbuyah serves as the model apostate. On his figure see, e.g., A. Goshen-Gottstein, The Sinner and the Amnesiac: The Rabbinic Invention of Elisha ben Abuya and Eleazar ben Arach (Stanford: Stanford University Press, 2000). For a historical novel which features both Beruriah and Elisha ben Abbuyah, see Milton Steinberg, As a Driven Leaf (Indianapolis: The Bobbs-Merrill Company, 1939). 


\section{Knowledge and Feminism}

The intertext applied by the scriptwriters here is the story of Adam and Eve in the Garden of Eden in Genesis 2-4. The tree of knowledge and carnal knowledge are combined one with the other, as they are in the Old Testament, and are additionally associated with Rashi's Beruriah episode. For the filmmakers this is the most important insight into this ancient text, and it is repeated often in the film. At one point we actually see Beruriah handing Joseph an apple, a visual allusion to the biblical scene of Adam's temptation in the Garden of Eden.

The issue is ever present. When Jacob and Beruriah's elder daughter, Michal, wishes to register for a rabbinical education, an unprecedented move by a woman in orthodox society, ${ }^{12}$ strongly opposed by Jacob, the following exchange takes place between father and daughter. Jacob tells his younger daughter she should try to live the Bible. He says: "Imagine Adam roaming around, enjoying everything. Every head of lettuce, every grain of rice, everything he sees." Michal responds to this with the words: "The Tree of Knowledge sounds much more tempting." And turning to her younger sister she asks: "What do you say, Naama, is it good to know or bad to know?" But Jacob refuses to discuss this with his daughters. Perhaps his own, idiosyncratic interpretation voiced later explains why.

The question of Jacob and Beruriah's daughter and her higher education are only one of the few glimpses the filmmakers allow us into the neo-orthodox world of thirty-plus Jerusalemites in their encounter with modernity and feminism. Unlike traditional men, Jacob is seen more than once standing in the kitchen and cooking, and the entire family jokes about his salad. On the other side, the only scene of a Jewish study house shown in the film is one of women - with Michal and her classmates. They are seen discussing a talmudic sugya, praying together, and then the camera moves on to the bookcase disclosing talmudim and other Jewish holy books.

But the lines are clearly drawn. Beruriah accompanies her woman friend to the rabbinate to file for divorce. The petition however is turned down by the male authorities. We can only guess that the reason is that the husband refuses to give his wife a get (bill of divorce). Jewish divorce remains a one-sided, male-initiated affair.

12 And in reality it is not an option for orthodox girls in contemporary Jerusalem. 
Even in Naama's elementary school, after the girls sing in front of the parents, one of the fathers complains to Jacob that this was immoral since "a voice in a woman is indecent" (bBerakhot 24a).

Jacob's refusal to allow his daughter to pursue a rabbinic career is part of his last ditch attempt to preserve the traditional male and female roles. Hence, his obsession with the stories of Genesis and the creation of humankind that have, over the years, served to define and delineate male and female roles in Jewish society.

\section{Adam, Eve, and Seduction}

In his last monologue on the Rashi episode, which Jacob performs in front of Beruriah's father, he once again returns, this time even more emphatically and overtly to the relationship between it and the Genesis stories. He says:

I feel as though I have to start everything all over again; to make amends. Maybe that's what Rabbi Meir felt. That he has to change the laws of creation; to go back to the Garden of Eden. Maybe that's what you wrote about. Maybe that's why you're afraid.... This. This is what you wrote about. This is what Rabbi Meir did... Don't lie to me. This is what Rabbi Meir did. He wanted to play God, to go back to the Garden of Eden, and reconstruct the whole story of the sin, but in this story there is no Adam, no Eve, no apple. There is Rabbi Meir, there is Beruriah and there is seduction.

But Beruriah's father denies that this was how he conceived of the talmudic Beruriah, or that this is what he wrote. To Jacob's words he retorts: "You are playing God."

Regardless of whether the filmmakers believe Beruriah's father's denial, or like Jacob, claim he is lying, seduction is high on the list of topics they examine. The film is indeed a reconstruction of the Rashi episode, but with a twist. Joseph, while searching for the book, tells Jacob:

I will keep away from Beruriah once I finish doing what you cannot do.

This is an enigmatic text. What is it that Jacob cannot do? Find the book or satisfy his wife? After the two scenes showing Beruriah and her husband in bed, both ending in estrangement, we suspect the latter. But while Jacob finds the book, hidden in his father's synagogue, nestled ironically together with the role of Torah in its cabinet, he entrusts Joseph to give it to Beruriah. Joseph says: "I understand exactly what is going through your head and you may as well forget it." To this Jacob reacts with the words: 
"You will do it." We cannot of course know if he refers here to handing Beruriah the book or to seducing her, but the short snippet, where we see Beruriah coming to Joseph for the book, which ends in an intimate scene, rather implies the latter. How intimate Joseph and Beruriah become is not quite spelled out in the film. While pressing her head against his chest, Beruriah asks Joseph where he got the book, and he tells her. At which point the scene dissolves, but we can imagine that it dissolves because it went nowhere. Beruriah probably left Joseph immediately and went back home.

\section{The Talmud on Seduction}

But the film does not end in this way. Instead, it becomes completely surrealistic: Beruriah removes her wig, and dresses as a prostitute. Jacob sleeps in a Jerusalem cemetery, cuts his hair, and then follows the prostitute (who is his wife) unwittingly through the streets of Jerusalem and into the Jerusalem hills, where they both bathe in one of the water sources located there, often used by contemporary pious Jews in rites of purification. The idyllic scene is indeed reminiscent of Adam and Eve, naked in the Garden of Eden before eating from the Tree of Knowledge.

What do the filmmakers wish to say by this ending? Aside from anything else, they have applied themselves here to another talmudic intertext, bQiddushin $8 \mathrm{1b}$, where it says:

Rabbi Hiyya bar Ashi was accustomed every time he prayed to utter the words: may the All-Merciful rescue me from my evil inclination. Once, his wife heard him. She said: since he has kept away from me all these years, why does he have to say these words? One day he was studying in his garden. She dressed herself to entice. She walked once or twice by him. He asked her: "Who are you?" She said: "I am heruta and I have returned today." He propositioned her. She said to him: "Bring me that pomegranate at the top of the tree." He jumped, took it, and brought it to her.

In this story a husband who is estranged from his wife, and who seems completely disinterested in sex, is easily tempted by a woman "dressed to entice." When our Rashi interprets the strange word "heruta" which the wife uses to describe herself, he says it refers to "a famous prostitute in town."13

13 On my interpretation of this episode, see Ilan, Silencing the Queen (Tübingen: Mohr Siebeck, 2006) 88-90. And see also S. Naeh, "Freedom and Celibacy: A Talmudic Variation 
There can be little doubt that this is the story the makers of the film had in mind when they decided to end the film with this surrealistic scene. We know that they knew it, for it appears in the same talmudic passage (sugya) which discusses the rabbinic opinion that women are light-minded (bQiddushin 81a), and which, according to Rashi, constitutes the grounds for Rabbi Meir's experiment. Emanuel, Beruriah's boss, actually mentions this reference specifically. I have taken pains in the past to analyze this passage thoroughly because it is not just the source of the saying that Beruriah mocks in the Rashi story, but also served as the inspiration for the entire episode he (in my opinion) invented. The Babylonians begin by stating this aphorism that women are light-minded and easily seduced, but then follow this up with a series of many stories which show the light-mindedness and easily seducible nature of men. I had concluded the discussion by stating that here: ${ }^{14}$

The Babylonian editors composed an entire sugya designed to undermine the idea that women are more light-headed than men.

Of particular significance among the stories told in this sugya is the following (bQiddushin 81a):

Rabbi Meir used to scoff at transgressors. One day Satan appeared to him in the guise of a woman on the opposite bank of the river. There was no ferry so [Meir] seized the rope and proceeded across. When he had reached half way along the rope [Satan] let him go, saying: "Had they not proclaimed in Heaven, take heed of Rabbi Meir and his learning, I would have valued your life at two nickels."

In this story it is none other than Rabbi Meir himself who is light-minded and easily seducible, and this story is found in the Talmud itself, and not in an eleventh century commentary. Therefore I am almost certain this is the story Rashi used and reversed in order to tell the Beruriah episode. But I doubt if this is the story the filmmakers of Beruriah used, when they ended the film by having Jacob follow a prostitute who is actually his own wife. It is hardly likely that they wanted to present Beruriah as Satan. It is more than likely that they wished to convey the same massage as the sugya, namely, that men are more prone to sexual seduction than

on Tales of Temptation and Fall in Genesis and its Syrian Background," in Judith Frishman and Lucas van Rompay, eds., The Book of Genesis in Jewish and Oriental Christian Interpretation (Louvain: Peeters, 1997) 73-89, who as can be seen from the title of his paper, indeed identifies the story with the seduction in Genesis.

14 See Ilan, "Beruriah has spoken well," 193. 
women. As has been shown by feminist scholars of the biblical text, the Bible itself, in its major story of the seduction of Eve, actually describes Adam as more easily seduced. To the seduction of Eve it devotes six verses (Genesis 3:1-6):

Now the serpent was more subtle than any beast of the field which the Lord God had made. And he said unto the woman: "Yea, hath God said: Ye shall not eat of every tree of the garden?' " And the woman said unto the serpent: "We may eat of the fruit of the trees of the garden: But of the fruit of the tree which is in the midst of the garden, God hath said: 'Ye shall not eat of it, neither shall ye touch it, lest ye die.' " And the serpent said unto the woman: "Ye shall not surely die: For God doth know that in the day ye eat thereof, then your eyes shall be opened, and ye shall be as gods, knowing good and evil." And when the woman saw that the tree was good for food, and that it was pleasant to the eyes, and a tree to be desired to make one wise, she took of the fruit thereof, and did eat.

About Adam all it says is, "and (she) gave also unto her husband with her; and he did eat"15 (Gen 3:6). Thus, the film's subtext of Genesis 3, the sugya in the Babylonian Talmud discussing the aphorism on women's lightmindedness, and the film itself all actually agree that while both men and women may be seduced, men are much more prone to it than women. The only source that seems to disagree with this position is Rashi. And his story forms the heart of the Beruriah film.

\section{Epilogue}

When I saw this film, however, I was left with the book. Joseph finds it for Beruriah, and after she has seduced her husband she can go back home, read what her father had written about the talmudic Beruriah, and discover what had been so outrageous about it that it merited a book-burning. We, the viewers, who receive a full interpretation of Rashi's Beruriah episode from the filmmakers, via Jacob, never receive any answer to this question. On the contrary, when Jacob confronts Beruriah's father with his theory about the contents of the lost book, the latter denies that that is what he had written and accuses Jacob of playing God.

So let me speculate. It cannot have been the seduction story that Beruriah's father had written about, because this story is already found in the near-canonic writings of Rashi, and, contrary to what the filmmakers

15 I have not been able to trace the source of this interpretation. 
claim, has caused the rabbis no qualms even until today. On the contrary, the story is used universally to discourage orthodox women from studying Torah. ${ }^{16}$ So what could a scholar say about Beruriah that would make his work so outrageous? I think my article on Beruriah provides the answer to this question, even if I say so myself. In my article I argued that tannaitic Beruriah was a real sage, a real learned woman, and that the rabbis of the Babylonian Talmud who theorized about her, could only produce a more grandiose picture of this woman. Had Rashi let things stay as they were, a flawless woman sage, a scholar who proves that women can be scholars just as men can, would have been transmitted to us through the ages. Rashi pulled the lofty scholar Beruriah back down to women's traditional place - in the bed and among fools. What if Beruriah's father in our movie had written just that? What if his book had argued that Rashi had falsified and corrupted Beruriah with a lie? What if he had presented to the world of Jerusalem's Jewish orthodoxy a convincing argument in favor of teaching women Talmud, based on the figure of Beruriah? Now this would have been a truly revolutionary book, meriting a public burning and an excommunication. It would have been bad enough to defame Rashi and accuse him of falsification, but to argue that Beruriah is the ultimate proof that women can study Torah, instead of being the ultimate proof to the opposite, as held by Jews who depend on Rashi for their portrait of this woman, this is absolutely the limit.

\section{Works Cited}

Goshen-Gottstein, Alon. The Sinner and the Amnesiac: The Rabbinic Invention of Elisha ben Abuya and Eleazar ben Arach (Stanford: Stanford University Press, 200o).

Heine, Heinrich. Tragödien, nebst einem lyrischen Intermezzo (Berlin: Fredinand Dümmler, 1823).

—. A Feminist Commentary to the Babylonian Talmud, Volume II.9: Massekhet Ta'anit (Tübingen: Mohr Siebeck, 2008).

Ilan, Tal. "Beruriah Has Spoken Well (tKelim Bava Metzia 1:6): The Historical Beruriah and Her Transformation in the Rabbinic Corpora," in Integrating Women into Second Temple History (Tübingen: Mohr Siebeck, 1999) 175-94.

- Jewish Women in Greco-Roman Palestine: An Inquiry into Image and Status (Tübingen: Mohr Siebeck, 1995).

- Silencing the Queen (Tübingen: Mohr Siebeck, 2006).

Ilan, Tal, Tamara Or, Dorothea M. Saltzer, Christiane Steuer, and Irina Wandrey, eds., $A$ Feminist Commentary to the Babylonian Talmud: Introduction and Studies (Tübingen: Mohr Siebeck, 2007).

16 As an orthodox student once told me that this story had been used by her grandfather to warn her of the dangers awaiting a woman who decides to study Torah. 
Meiri, Sandra. "Memory, Trauma and Ethics in Judd Ne'eman's Feature Films," in Yosef Raz, ed., Israel: Studies in Zionism and the State of Israel 14 (2008) 32-69.

Morag, Raya. "Sound, Image and forms of Remembrance: Israeli narrative Cinema during the Second Intifada," in Yosef, Raz, Israel 14 (2008) 71-88.

Naeh, Shlomo. "Freedom and Celibacy: A Talmudic Variation on Tales of Temptation and Fall in Genesis and its Syrian Background," in Judith Frishman and Lucas van Rompay, eds., The Book of Genesis in Jewish and Oriental Christian Interpretation (Louvain: Peeters, 1997) 73-89.

Steinberg, Milton. As a Driven Leaf (Indianapolis: The Bobbs-Merrill Company, 1939).

Yosef, Raz. "History and Memory in Israeli Cinema," in Israel: Studies in Zionism and the State of Israel 14 (2008) (Hebrew). 


\section{INDEX}

9/11, 8, 20, 38, 39, 75, 95-96, 115, 117

Academy Awards, 17, 20, 34

Achilles, 10, 44, 153-92

actors and acting, 18, 28, 33, 41-44, 47-48, $5^{0}, 58,60,75,88,104,131,135,143,145^{-46}$, 167, 176, 178-79, 185-6, 196-97, 199, 207, 210, 214, 280-82, 303, 315

Adam, 14, 141, 317, see also, Eve

Adams, John Quincy, 23-25, 37, 39

adaptation, 11, 17, 34, 45, 65, 66, 99, 117, 195-96, 200, 213-14, 225-26, 272, 282, 292

Adonia, 13, 269

adornment, 277

Adorno, Theodor W., 11, 199, 203, 211

Aeschines, 10, 154, 161-62, 165-66, 170, 172, 304

Aeschylus, 10, 154, 161-66, 170, 172, 217

Afghanistan, 26, 118

Agamemnon, 11, 155, 162, 172, 177-79, 182, $184-85,192,205$

alterity, 112

ambiguity, 7, 43, 71, 96, 115, 119-20, 169, 199, 231, 239

ambivalence, 11, 112, 114-15, 137, 140, 142, $144,146,148,168,181,193,196,208-9$, 259, 278

America and American, 4, 6, 8, 13, 17, 19-39, 41, 48, 50, 54-55, 57-58, 61-63, 95-103, 112-13, 117-18, 120-21, 146, 195, 229-31, 238, 240, 242-44, 251, 253, 258-62, 271-72, 274-75, 277, 286, 292, 296

Amistad, 23

anal fixation, 114

anal rape, 124, see also, rape

Ancients, 5, see also, Thematics

androgyny, 8, 66, 77, 108, 110-1, 117

Andromache, 10, 168, 188-91

Antony, Mark, 8-9, 123-35, 137, 139-41, 143

Aphrodite, 138, 278, 283, 300, 304, 307

Aristophanes, 12, 263-70

Aristotle, 19, 72, 265, 271

Artemis, 12, 259-61, 294, 297

artist, 2, 5, 14, 28, 36, 143-44, 213, 253, 255, 275, 282, 299, 301-02, 304, 306
Athens and Athenians, 7-8, 13, 31, 74, 99, 213-15, 218, 257, 263-67, 276, 296, 299, 303

audience, see spectatorship

Aurelius, Marcus, 18

authority and authorities, 33, 74, 128, 132,

144, 150, 204-5, 229, 242-44, 260, 311,

315,318

authoritarian, 113, 119

Avedon, Richard, 147-48

Aztec, 26-27

Bara, Theda, 146-47

barbarian, 6, 10, 214, 239, 318, 322

barbaric, 7, 52, 54, 90, 119, 217

Bardot, Brigitte, 204

Barthes, Roland, 5, 252, 254, 256, 261, 269, 279-80, 297

BBC, 5, 80, 123

beauty, $9,13,57-58,72,84,102,141,165$,

$179,243,253,279,281-82,285,300,304$

belief systems, 119, 221

Ben-Hur, 5-6, 17-19, 21, 27-28, 29, 33-37, 39

Benioff, David, 10, 166

Benjamin, Walter, 44

Beruriah and Beruriah, 5, 14, 309-23

Bible and Biblical, 5, 55-56, 196, 285-86, 306, 308-9, 318, 322

blockbusters, 4, 28, 33, 74, 166, 179-80

Blood and Sand, 17, 51

body, 1-2, 4, 6, 10, 13, 41-45, 47, 50, 52-54, $57-61,65,71,85,87,112-13,115,123-25$, $130,132,134,138,140,144,146,154-55$, $163,176-81,201-2,205,214,254-55$, 26o-61, 263, 265-66, 275, 280-82, 286, $290,295,300,305,315$

box office, 4-5, 17, 20, 33, 50, 101

boy-lover, 8, 79, 111

Bravmann, Scott, 4, 97, 118, 120

breast, $83,138,140,145$

Briseis, 10-11, 155, 168-71, 180-88, 191-92

Bronfen, Elisabeth, 9, 137-50, 280, 284, 286-87, 293, 296

Brooks, Louise, 286

Buñuel, Luis, 272

Bush, George W., 26, 36-39, 103, 119

Butler, Judith, 3, 10, 80, 130, 178, 225 
Caesar, 5, 8-9, 29-31, 44, 52, 123-24, 131-32, 140-43, 147, 232

Caesar and Cleopatra, 5, 9, 141

camera, 1, 71, 87, 90, 92, 141, 179, 183-84, 186, 188-89, 201-3, 205, 208, 251, 254, 265, 278, 282, 318; angle, 132, 183, 186, 189, 201-2; point of view, $1,57,65,83$, 180,294

cartoons, 249-52, 254, 258-62

castration, 107, 124

Catholic, 14, 57, 286

celebrity, 9, 13, 20, 28, 38, 43, 142-46, 280 censorship, 2, 12, 180, 233, 239, 241, 242, 244, 261

charisma, 9, 19, 57, 142

charm and charms, 9, 76, 88, 128, 137-39, 142-44, 146, 278, 292

chauvinism, 118, 217

chest, 56, 107, 134, 179, 320

children, 69, 72, 88, 124, 130, 142, 158, $213^{-15}, 223,225^{-26}, 252,255,261,264$, 266

Christ, 27, 29, 39, 140

Christianity, 3, 6, 13-14, 18-19, 26-27, 29, $48,56,119,137,145,154,162,172,222-23$, 232, 265, 267, 283-86, 290, 295, 298-99

CinemaScope, 34

cinematography, 28, 52-53, 204, 250, 255

Cleopatra and Cleopatra, 5, 9, 44, 52, 54, 125-30, 134, 137-50

Clinton, Bill, 26, 35

code and codification, 2, 4, 6, 120, 180, 203, 244, 250, 312

Colbert, Claudette, 146

Cold War, 3, 75, 106, 117

colonialism, $3,26,52,262$, see also, postcolonialism

Colosseum, 31-32, 65

Commodus, 18, 21, 32

Comolli, Jean-Louis 6, 41-44, 6o-61

Corbeill, Anthony, 127, 129, 135

Corbucci, Sergio 41, 51-52, 54, 56, 59

costumes, 1, 85, 115-16, 145, 147, 206, 220, 221, 252, 282

Crassus, Marcus Licinius, 45-46, 54

cross-dressing, 8, 123, 129-30

Crowe, Russell, 36, 65, 187

Cruise, Tom, 100

cults, $8,13,100,101,221,257,258,262,263$, $267,268,269$

cultural, 1, 2, 4, 8, 9, 12, 18, 19, 28, 34, 44, 50, 53, 61, 66, 77, 80, 82, 90, 91, 96, 97, $102,103,106,111,114,119,138,139,140,141$, $143,145,146,176,213,229,250,252,253$,
$255,256,257,258,262,263,265,266$, 268, 269, 271, 278, 281, 286, 294, 299, 301, 303,304

Dalí, Salvador, 272

de Chirico, Giorgio, 288

death, 7-8, 14, 27, 32, 42, 47-48, 56, 83, 92, $96,98-99,123-25,128,134-35,137,143$, $145,155,157-61,164-65,168,181,186$, 189-90, 205, 214, 216-17, 226, 235-36, 259, 264-67, 274, 286, 289-94, 299-301, $305,312,314-15$

decadence, $71,80,84-85,133$

Demetrius and the Gladiators, 18, 34

DeMille, Cecil B., 34, 58, 127, 129, 146

democracy, 6, 19, 32, 35-36, 98, 113, 118, 120, 213, 222, 253, 264-66, 268, 303-04 demographics, 20, 34

desexualized caricature, 108, see also, sexualization

desire, 6, 21, 29, 32, 58, 84, 91, 113, 117, 127, $139,142,145,156,159-60,168-70,172$, $198,201-3,205,251-52,254-55,258,260$, $275,278,281,288,293,317$

Detienne, Marcel, 1, 13, 257, 269

deviance, 12, 68, 71, 127-29

Diana, 12

Dionysus, 259, 261, 265-67

director, $10,12,18,28,50,65,68,80,82-83$, $100,115,166,175^{-76}, 203,205,213-14$, $263,266,275,279,282,290$

discrimination, 115, 119, 217, 240-41

Disney, Walt and Walt Disney Company, 12-13, 34, 249-50, 252-54, 258, 261-62, 268-70

diva, $13,280,296$

divine, 2, 25, 138, 156, 206-7, 222, 224

dominance and domination, 6, 8, 13, 22, 31, $53,60,80,87,123,129,177,186,223,225$, 230, 238, 254, 256, 279

Dornhelm, Robert, 41, 45, 51, 53, 59

Douglas, Kirk, 23, 41, 45, 48-50, 53, 62, 195 drama, 11, 14, 20, 21, 31, 44, 66, 70, 75, 91, $142,144,160-61,175,198,213-14,216-21$, $225^{-26}, 253,262,263,265,286-87,292$, 312

economic and economics, $3,22,33,37-38$, $53,57,59,95-96,146,242,261,276-77$, 297, 299

Eden, 14, 318-20

effeminacy and effeminizing, 66, 80, 89, 127-29, 127-31, 156, 199, 216

Eleusinian Mysteries, 267 
embodiment, 6, 9, 6o, 117, 137-38, 143, 148

entertainment, 6, 18, 32, 80, 92, 94, 252, 298

Ephialtes, 65, 71, 74, 77, 84, 99

eros, 126

eroticism, $10,57-58,77,86,113,125,128$, $137,139,141,154,161-62,170,180-81,185$, 204-5, 279, 282-83, 289, 295

ethnicity, 4, 12, 35, 47, 55, 80, 99, 106, 110, 177

Euripides, 213-17, 220-21, 224-27

Europe, 5, 11-12, 43, 62, 118, 195, 219, 223-25, $253,255,258,-61,265,271,276$

Eve, 13-14, 130, 135, 137, 141, 156, 173, 26o, 271-72, 284-88, 317-20, 322

evil, 6, 27, 35-37, 143, 176, 220, 233, 235, 251, $253,258,260-61,272,277-78,320,322$

exhibitionism, 146, 202

exploitation, 2, 210

Fahrenheit 9/11, 20, 38-39

Fall of the Roman Empire, The, 5, 17-18, 200, 205, 211

family, $6,10-11,18,48-49,56-57,67,100$, 126, 131-32, 137, 182, 187-92, 201, 226, 237, 312,318

fantasy, 9, 52, 66, 84, 92, 100, 113, 140, 142, 146, 229-30, 236-37, 255, 263, 305

Fast, Howard, 47-49

female, $260,263,267,269,270,275^{-7} 8$, 281, 284, 287, 291, 295, 299-300, 303-7, 312,319

femaleness and femininity, 1-3, 9-10, $14,52,55,5^{8-59,67,70-71,73,76-77}$, 83-84, 89-90, 107, 112, 125-30, 138, $142-43,146,148,155,170,175-76,178-81$, $185,189-91,198,202,205-7,214-16,226$, 229-31, 244-45, 252, 254-557, 286, 290, 305

feminism and feminists, $3,10,12,57,139$, 179-81, 219, 229, 252, 257, 263, 268-69, 309, 318,322

feminization, $10,5^{2}, 125^{-27}, 129,170$, 180-81

femme fatale, 9, 13, 76, 139, 292-95, 296

femoral intercourse, $162-63$

fiction, 4, 5, 7, 9-10, 34, 38, 41, 43-45, 47, 50-51, 53-54, 57, 59-6o, 61-63, 97, 99, 118-20, 192-93, 230-32, 236-238, 240-41, 244, 282, 304

figlio di Spartaco, Il, 51

film theory, 10, 179, 257, 266

Foucault, Michel, 89, 93, 218, 258 foreign and foreigner, 8-9, 11, 19, 22, 24 , $26-28,37-38,49,67,72,111-12,118,120$, 124-25, 130, 138, 203, 207, 213-15, 225

Francisci, Pietro, 112, 196-97

Franzoni, David, 23, 28, 31-32, 35

Freda, Riccardo, 41, 45, 47, 50, 53, 55-56, $59,237,244$

freedom, $6,22,24-25,27,30,32,36,46-47$, $5^{0}, 57,72,74,81,114,117-20,210,268$, 320,324

Freud, Sigmund, 253

Friedberg, Jason, 8, 95, 100

friendship, 10, 153, 157, 166, 230, 244

Gabrielle, 12, 231, 233-34, 236, 239-40, 243

Gardner, Ava, 13, 272, 279, 282, 286, 290, 295,297

gayness, 4, 8, 108, 110-11, 113, 119, 166-67, 231

gender and gendering, $1-5,7-8,10-14$, 21, 55, 66-67, 75-77, 80, 83-91, 99, 101, 111-12, 123, 127, 130, 133, 144, 154, 156, 161, 175-78, 181, 189, 196, 199-200, 205, 207-10, 215, 229-31, 239, 243-44, 249, 254-58, 26o, 262, 272, 275-76, 290-92, 293, 294, 306, 309

genitals, 107, 126, 164

German, 3, 14, 41, 48, 51, 55, 58, 176, 253, 277, 301-3

Girotti, Massimo, 45, 47

Gladiator, 5-6, 17-19, 21, 23, 26, 28-31, $33-39,49,51,54,61-62,187,192$

glamour, 84, 146, 148, 271, 277, 281-82, 286

Godard, Jean-Luc, 3, 11, 195, 200-5, 210-11

gods and goddesses, 9, 12, 26, 30, 79, 85, $108,115,127,137-38,140-45,148,155$, 159-160, 165, 182, 184, 191, 199, 221-24, 232-36, 259-61, 267, 275-83, 288, 290, 300, 304

Gorgo, 7, 66-79, 85-89, 119

government, 6, 18-19, 22-23, 25, 27-30, 33, $35,95,125,139,242$

Göring, Hermann, 98

graphic novel, 84, 91, 93

Greengras, Paul, 116

Guthrie, Thomas Anstey, 282

gynaikokratia, 72

$\mathrm{HBO}, 5,123$,

Headey, Lena, 79, 119

Hector, 10, 154-59, 165, 168-70, 175-79, 182, 186-91

Helen, 34, 128, 168, 175, 180, 185, 216, 231, 244 
Hephaestus, 2, 154, 156-57, 275

Hercules, 3, 5, 12, 17, 34-35, 52, 89, 107, 112, 119, 121, 128, 196-97, 229, 232, 240

Hercules: The Legendary Journeys, 3, 5, 12, $34-35,229,240$

hermaphrodite, $9,84,130$

heroes, $3,6-8,17-18,20,30,35,37,41$, $44-47,5^{0-53}, 55^{-61}, 63,70^{-71}, 75^{-77}$, 95, 100, 102, 107, 112-13, 161, 165, 178-79, 181-82, 187, 195-96, 200, 214, 216, 227-31, $244-45,263-67,294,306$

Herodotus, $7,65-66,72-73,78,98-99,106$, 121,218

heroines, 13, 75, 102, 142, 230, 231, 236, 255, 259, 294

heroism, 7, 66-68, 76-77, 84, 87, 91, 96-98, 100-1, 105

Hesiod, 13, 137, 271-72, 275-79, 282, 285-86, 296-97

Hestia, 12

hetaera, 13, 304

heterosexuality, 1, 10, 48, 77, 107, 111-112, 120, 166-70, 172, 177, 179-180, 182

Hilton, Paris, 100

Hinduism, 12, 229, 233, 236-37, 241, 243

historicity, 5, 19, 50, 62

Hitler, Adolf, 303

Hollywood, 2-7, 17, 21, 33, 37, 39, 54-57, 61-63, 74-75, 78, 80, 90, 99, 101, 121, 141-42, 145-48, 153, 166, 173, 175, 179, 181-82, 186, 192-93, 197-98, 240-41, 25354, 26o-61, 269, 272, 279-81, 288, 295-97

Homer, 10-11, 74, 153-54, 165-66, 168-70, $172-73,175,179,184,186,192-93,195$, 198-200, 203, 209-10, 290-91

homoeroticism, 2, 33, 112, 115, 162, 167, $180-81$

homophilia, 8, 107, 110, 117

homophobia, 66, 79, 117, 239-40

homosexuality, 1-2, 8, 10, 57, 79, 110-13, $119,121,127,153-54,161-164,166-72,177$, 180-81, 238-40

homosociality, 10, 97, 156, 168-73, 214

Hopper, Hedda, 271, 281-82

husbands, 7, 14, 67-71, 75, 77, 79, 86, 102, $132,149,185,188-91,198,215,264,312-22$, see also, wives

hybridity, 9, 33, 113, 119, 137-38, 143-46, 217

iconographic, 140-41, 144, 275

iconography, 42, 44, 52, 54-55, 6o-61, 148, 236-37

identification, 4, 49, 130, 143, 172, 176, 208, 214, 251, 257, 290, 309 identity, 4, 13, 52, 80, 112, 130, 156, 178, 199-200, 208, 214, 219, 223, 254-55, 266-67, 280, 290, 298-99, 307

ideology, 3, 8, 19-20, 36, 38, 48, 56, 68, 82, 91, 96-97, 118, 120, 138, 178, 193, 224, 252, 254-56, 258-60, 268

images and imagery, 1, 4, 6, 9-10, 13, 35, $41-47,51,53,56,60,71-72,75,77,84-85$, 89, 90, 96, 110, 117, 130, 138-39, 142-45, 178-79, 188, 191, 198, 202-3, 206, 209, 250, 255, 257, 273, 275, 287-89, 291, 295, 305,313

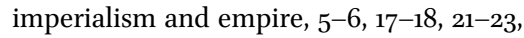
$25^{-27}, 29,31,36,38-39,48,52,63,118$ initiation, 8, 75, 101-2, 106, 111 institution, 50, 214, 222, 316 intimacy, 125, 133, 156, 160-62, 164, 169, 206, 236, 252, 268-69, 291, 301, 320

Iraq, 26, 28, 35, 118-19

Jerusalem, 14, 313-14, 316, 318, 320, 323 Jolie, Angelina, 100

Judaism, 3, 14, 311

Koestler, Arthur, 41, 48-49

Krishna, 12, 229, 232-43

Kristeva, Julia, 218-19, 226

Kubrick, Stanley, 6, 18, 37, 41-42, 45, 47, 49-50, 53, 55-57, 59, 61

Lacan, Jacques, 9, 142, 148

Leigh, Vivian, 9, 141-142, 148

Leonidas, $7,65-87,90,92,96,98-102$, $106-7,111,116$

lesbian, 4, 12, 71, 229, 231, 239-41, 243-44

Lewin, Albert, 13, 271-72, 274-75, 278, 281-82, 284, 286, 289-90, 295

Lincoln, Abraham, 24-25, 37

Loraux, Nicole, 214, 218, 226, 277, 296

Loukoumades me meli, $5,13,263$

love, 11, 13-14, 32, 50, 56, 68-69, 71, 74, 77, $84,87,111,115,125-26,128,132-33,138$, $140-42,144-45,147-48,153,155,158$, 161-70, 172, 180, 185, 192, 217, 221, 223-24, 233-35, 259, 264-65, 267, 271, 273-74, 278, 281-83, 289-92, 295, 299, 317

Lupo, Michele, $5^{1}$

lust and lusty, 8, 48, 100, 106, 11, 125, 179, $189,193,273$

Luxemburg, Rosa, 41, 48

Maciste, 52, 56, 62, 197

make-up, 1, 85, 129-30, 134, 215, 282 
maleness, 2, 6-7, 10-11, 13-14, 41, 52, 55, $57-59,62,66-68,71,75^{-77}, 83,-85,87$, 89, 91, 97-98, 100-2, 107, 111-14, 117, 120-21, 123-24, 127, 129-32, 134, 144, $153-54,156,158,165,168-70,172-73$, 175-77, 179-81, 189-90, 192,-93, 196, 199, 201-2, 206-10, 214, 216, 219, 229-30, 254-55, 257-58, 26o-61, 263, 270, 275, 278-79, 287, 293-94, 299, 306, 309, 311, 318-19; see also, masculinity

Malea, Olga, 12-13, 249, 263-66, 268-69 Manifest Destiny, 6, 17, 19, 25, 35-36, 38, 97

manliness, 70, 85-86, 98, 106-7, 111, 123-24, $127,131-32,135,176,178$

marginalization, 3, 176, 196, 229

Mars, 138, 141

Marseillaise, La, 43

masculinity, $1-3,6-8,10-11,54-56,59-60$, $62,66,71,80-81,83,85-89,91,100-1$, $107,110,113,123-25,128,130,134,142$, 144, $-46,170,175-79,181-82,185,190$, 192-93, 196, 199, 208, 218-19, 256-57, 267, 290, 306

masculinization, 8, 110

Maté, Rudolph, 7, 65, 67, 74, 76, 106, 117

McCarthyism, 49, 57

Medea, 3, 5, 11-12, 213-26, 253

media, 1, 31-32, 35, 43, 45, 53-54, 57, 59, 82, $85,91,94-95,100,149,180,225,232,239$, 240-41, 243-44, 250, 253, 256, 280, 303

media theory, 3

Meet the Spartans, 5, 8, 66, 95-97, 99-101, 103-8, 110-12, 114, 119-20

Mépris, Le, 3, 11, 195-96, 200-4, 208, 210-11 Metro-Goldwyn-Mayer, 17, 34, 274, 280-81 Miller, Frank, 7, 65-69, 71, 74, 76-79, 82, $85,92,94,106,117,121$

mise-en-scène, 44, 82, 142, 170, 201, 202, 204, 205, 207, 208, 210

misogynist, 59, 140, 142

Monroe, Marilyn, 141, 147-48

Moore, Michael, 20, 33, 38-39, 54, 61

morality, 23, 53, 56, 59-6o, 77, 87, 90, 127, $132-34,175,265,292,305,316$

Mulvey, Laura, 10, 179, 189, 193, 255, 270, 284, 296

muscles, 1, 6-7, 41, 54, 57-59, 61, 83, 107, $112-13,167,179,181,188$

music, 1, 41, 147, 188, 202, 220-21, 274

MTV, 115,120

myth and mythology, 2, 5-7, 9-14, 42, $45,53-54,56,60-61,71-73,89,96-97$, 100, 107, 110, 118-19, 137-41, 153, 191,
200, 213-15, 217-23, 225, 232-33, 244, 249, 252, 254, 259-6o, 262-63, 271-72, 275, 277-80, 283-87, 293, 295-96, 299, 306

mythopoesis, 5

narrative and narratology, $5^{-7}, 12-13,18$, $21,29,34,50,56,66,74,81-82,87,91-93$, $108,113,139,141,166,173,175,179,191,193$, 195-200, 205, 208-10, 220, 230, 244, 249, 251-54, 257-59, 268, 271-72, 276, 285, 298-99, 310-11, 324

nationalism, 52, 79, 217, 269, 299, 301,

National Socialism, 14, 253, 298-303, 305-306

Nero, 44, 58, 63

New Realism, 300

Nicholson, William, 36

Nord, Paul, 74

Nostro, Nick, 51

nudity, $14,41,58,66,68,70,73,84-85,106$, $112,138,140,145,149,164,180-83,185$, 201-2, 221, 261, 267, 273, 282-83, 285, 299-300, 303-5, 320

O'Sullivan, John Lewis, 25

objectification, $6,58,113,121,125,140,170$, $180,182,185,205,257,259-60,262,281$

occupation, $6,22-23,25-27,29$

Octavian (and Augustus), 44, 123, 125-26, 131-33, 135

Odissea, L', 5, 11, 37, 195-96, 205-10

Odysseus, 11, 48, 166-68, 178, 182, 186, 195-201, 203-4, 206-10, 290-91, 297

Odyssey, 11, 34, 37, 195-98, 200, 203, 205, 209-10, 277

Orient, 4, 7, 23, 79, 80, 83-84, 90, 94, 129, 137, 255

orientalism and orientalization, 9, 52, 80, $84,89,94,116,130$

Otherness, 2, 7-8, 11-12, 26, 35-36, 214-15, $217,219-21,223,225$

Pabst, Georg Wilhelm, 13, 286, 292-93

Pandora, 2, 5, 13-14, 137, 271-97

Pandora and the Flying Dutchman, 5, 13-14, 271-97

Paris, 138, 141, 148, 168, 177, 182, 187-88

Pasolini, Pier Paolo, 3, 11-12, 213-14, 216-27, 253

paterfamilias, 124, 177

patriarchy, 48, 168-69, 172, 176, 225, 255, 258-62, 269

patriotism, 21, 24, 39, 258, 261-62 
Patroclus, 10, 153, 154-73, 180, 182, 186-87, 190

peace, $6,22,24,35-36,57,88,177,182$, $186-87,192,263,294$

pederasty, $8,110-11,167,172$

pedophilia, 13, 172, 264, 267

penetration, 8, 69, 118, 123-24, 126, 135

penis, 8,123

peplum, 11, 43, 53, 57, 101, 112-13, 119, 195-96, 256

Persephone, 259, 263, 267, 270

Persians, 4, 7-8, 65-69, 71-72, 74, 76, $78-86,88,89,92,95,98-99,103,105^{-6}$, 108, 110-11, 114-19, 217-18

perversion, 86, 115, 117, 239, 269

Petersen, Wolfgang, 10, 153, 166, 168, 170, $175^{-76}, 184,192$

phallic and phallus, $83,107,170,185$

Pitt, Brad, 10, 100, 166-67, 179-80

Plato, 10, 154, 161-62, 164-65, 170, 173, 216, 223

Plutarch, 7, 41, 45-46, 72-73, 76-77, 127-28, 134- 35,140

politics, 3-5, 7-9, 12-14, 18-23, 26-34, 41-42, 49, 53, 56, 60, 75, 86, 88, 95-99, $102-3,106,111-13,115,117,119-20,124$, $127,132,137-39,142-49,213-14,219-20$, $222-23,242-43,254,256-61,263,265-69$, 298-99, 303, 306, 309

Polyphemus, 199, 203, 206

polytheism, 253, 262

popularity, 1, 5-8, 17, 19-20, 22, 32, 34-35, $37-38,41,43-46,48,50,52-53,55^{-6}$, 66, 79, 83, 99-102, 130, 135, 175, 179, 225-26, 230-33, 236-37, 244-45, 250-55, $258,262,270,280,296,298,301$

postcolonialism, 4, 12, 219

potnia theron, 12, 259

power, 2-4, 6, 9, 13-14, 20, 31-32, 37, 46-47, $55,57,75,84-85,90,102,110,113-14,120$, $123-33,137-48,156-57,176-77,183,197$, 199, 209-10, 214-22, 243, 250-55, 258-6o, 263, 265-66, 269, 281, 287, 290, 301, 311

Praxiteles, 299, 304

priests and priestesses, 27, 67, 79, 183, 191, 223, 286

producers, $5,18,28,65,176,232,241,243-44$, 258, 279

production code, 2, 12, 55, 180, 233, 239-44

propaganda, $17,28,34-35,37,50,82,84$,

$89,92,117-18,120,139-40,301-2$

prophecy and prophets, $27,157,224$

prostitution, 14, 130, 138, 143, 299-300,

$304-5,320-21$ psychoanalytical, $3,198,253-55,258$

public, 6, 14, 18-19, 22, 28, 31-34, 37, 57, 70, $75,126-27,131,134,138-39,144-45,147$, 165, 179, 213-14, 225, 232, 236, 238-43, $251,255,257,265-68,280,290,323$

queer and queering, $3-4,8,10,97,110-1,116$, 120, 130, 135, 169-70, 172

Quo Vadis, 34

racism, 4, 66, 80, 117-19, 120, 217, 240-41, $3023,305^{-6}$

rape, $54,68-69,71,77,87-88,119,124,260$, 269

rationality, 185, 189, 220, 223, 265

reality, 1, 43, 45, 98, 121, 175, 197, 199-200, 203, 221-23, 225, 250, 254-55, 258, 294, $302,306,316,318$

rebellion, $11,23,29,30,51,55,72,83,216$, 219

reception, $1-3,8,10,12,20-21,28,44-45$, $53,57,62,66,74-75,79-80,89-91,93$, $96,98,118,166,181,213,250,252,256$, $258,265-66,268,271,284-85$

redemption, $13,33,123,134-35,283$, 289-95

Reeves, Steve, 52, 197

religion, 2, 12, 49, 65, 68, 74, 118, 221-24, 229, 232, 235-37, 240-41, 244, 253, 280, 303, 309, 316

Renaissance Pictures, 240-42

Renoir, Jean, 43-44, 62

revolution, 6, 18, 20, 21, 23, 38, 41, 48, 95-96, 323

Raimi, Sam, 229

Riefenstahl, Leni, 33

ritual, 13, 101, 110, 116, 222-25, 227, 235, 249, $25^{2-54}, 257-63,265,267-69$

Robe, The, 34

Robocop, 83

Rome and Rome, 3, 5, 8, 29-32, 45-49, $52,55,61-63,65,123-35,139-40,142$, $146-47,201,301$

Rossi, Franco, 5

sacrifice, 3, 13-14, 81, 87-88, 90, 98, 100, 118, 138-39, 145, 221-24, 249, 267, 273, 277-78, 291, 293-95, 299, 306, 309, 314

Said, Edward, 4, 84, 94

Samson, 34, 52, 58, 197

Samson and Delilah, 34, $5^{8}$

Saurin, Bernard-Joseph, $5^{2}$

Saving Private Ryan, 20-21

Scott, Ridley, 17, 36, 38 
scripts, 18, 28-29, 35, 49, 142, 166, 235, 256, 281, 312, 314

seduction, 9, 13-14, 137-38, 140-41, 143, 145, 147-49, 255, 260, 264, 273, 277, 286-87, 292, 311-14, 316-17, 319-22

self-destruction, 84

Seltzer, Aaron, 95, 100-1

sex symbol, 129, 179

sexual assault, 70-71, 77, 124

sexual intercourse, 170

sexual organ, 107

sexuality, 7-10, 66, 68, 70-71, 77, 102, 107-8, $111-12,117,123-24,126-27,130,132,135$, 137-39, 141-42, 144-46, 149, 154-55, 162, 170, 172, 182, 189, 193, 231, 239, 255, 257, $263-66,293,303,316-17,321$

sexualization and desexualization, 10, 108, 166, 168, 260

Sinner, The, see Die Sünderin

slaves and slavery, $3,18,23,25,48,52,55$, $77,117,124-25,132,155,184,265$

Snow White and the Seven Dwarfs, 3, 5, 12, 249-54, 258-62, 268-69

Snyder, Frank, 7, 65, 66, 68, 73, 75-76, 79, 89, 95, 96, 100, 106, 108, 119

Something's Got to Give, 149

sovereignty, 4, 138, 144, 147-48, 222, 226, 288

Soviets, 35, 117, 255

Sparta and Spartans, 5, 7-8, 65-93, 95-100, 102-8, 110-11, 114-20, 168, 182-83, 188-89

Spartaco, 45, 47

Spartaco e i dieci gladiatori, 51

Spartacus, 5-6, 17-18, 28, 37, 41-63

Spears, Britney, 100, 103-4

spectatorship, 1, 6-7, 10, 19-21, 31-37,

$43,47,58-59,66,71,73,75^{-76}, 80,83$, 91-92, 112-13, 116, 125, 128, 132-33, 140, $146,161,166-72,176-77,179-183,188-89$, 192, 210, 214-15, 218, 226, 230-33, 273-74, 279-82, 290, 295, 298-305, 322

Spielberg, Steven, 20, 23, 34

Spivak, Gayatri, 4, 89, 93

Stallone, Sylvester, 100

(movie) star and star system, 32, 50, 57, 100, 103, 142-43, 146-49, 178-79, 193, 201, 268, 279-82, 286, 290, 295-97

stereotypes, $5,7,13,66-67,76,82,89-90$, $119,189,214,216,226,257-58$

St. George, George, 74

Stone, Oliver, 33, 169, 172, 185

structuralism, 97, 120, 257

subversion and subversiveness, 20, 105, $111-12,117,130,178,192,214,220,257$, 263,269 success, 4-5, 8, 17, 19-20, 36, 48, 101, 138-39, $175,179,197,199,223,229,254-55,268$, 279-81, 286, 295

suffering, 11, 36, 158, 200, 210, 217, 222, 224, 263,315

suicide, 14, 140, 216-17, 291, 293, 303, 312

Sünderin, Die [The Sinner], 5, 13, 299-303, $305^{-6,} 317,323$

superiority, 4, 79, 99, 114, 185, 251

surrealism, 272, 281, 288, 296, 313, 320-21

taboos, 10, 14, 153, 167, 169, 172, 180, 221, 261, 265,303

Tapert, Robert, 229

Taylor, Elizabeth 9, 43-44, 63, 127, 147-49

Technicolor, 274

television, $1,3,5^{-6,11-12,17,34-35,45,51,}$ $53,57,89,100,102-3,127,148,195-97$, 205-6, 210, 229-30, 236-37, 241-42, 244, 251, 258, 268, 280

Terminator, The, 83

terrorism, 12, 28, 35, 115-17, 120, 220

texts, $13,41-42,45-46,50,96,137-40,153$, $236-37,239,249-50,256,263,280,314$

theater, 11, 28, 37, 41, 47, 52, 54, 143, 213-14, $25^{1-52,254,256,265-66,312}$

Thematics, 5,12

Third Reich, 79, 306

$300,4-5,7-8,65-67,73-80,83-85,87$, $89-98,100,103,105^{-6}, 110-12,114-21,154$, 172, 293

3oo Spartans, The , 5, 7, 65, 74, 77, 106, 118

Tinted Venus, The, 282

tongue, 124, 236

tragedy, 9, 30, 52, 6o, 115, 134, 213-16, 225, 227, 312

transvestites, 85,130

Troy, 3, 5, 10, 34, 128, 153-54, 159, 166, 168-70, 172-73, 175-89, 191-93, 205, 268

Trumbo, Dalton, 18, 37, 49-50, 61

tyranny, 21, 32-33, 35, 74, 82, 115

Ulysses, 5, 11, 48, 195

United 93, 115-16

United 30o, 5, 66, 95-97, 100, 115, 117, 119

United States, 3, 6, 12, 22-23, 25, 27, 31, $33,35^{-37}, 47,57,117,119,232,236,238$, 242-44, 268

Universal Studios, 12, 49, 229, 233, 239-44

Ursus, $5^{2}$

Ustinov, Peter, 18, 44 
vaginal symbol, 170

vases, $10,55,249,251-52,259,261-63,268$, 285

Vendetta di Spartacus, La, 51

Venus, 9, 137-38, 140-46, 148, 150, 282-83, 300, 304

Vidali, Giovanni Enrico, 41, 45, 47, $5^{8}$

viewers, see spectatorship

villains, $6-7,18,32,35,71,77,237$

violence, 4, 52, 55, 97, 99, 117-18, 121, 124, 131, 177, 181, 184, 186, 192, 200, 209, 211, 226, 230-31, 244, 258, 260, 265, 269, 276

virgin, 12, 183, 185-86, 191, 259-61, 264, 276

virile and virility, 8-9, 50, 123, 125, 128, 130-35, 182, 197

vision, 1, 113, 142, 160, 203, 250, 289, 301-2, 304, 306

vulnerabilty, $8-9,56,83,121,123-24,126$, 130, 188

Wagner, Richard, 13, 272, 274, 291-94, 296 Wallace, Lew, 17-18, 23, 26-27, 29, 39

war, 3, 10, 13-14, 20-29, 34, 37-39, 45-49, $56-57,63,72-75,80,86,88,90,92-93$, 96, 98-99. 101-2, 106-8, 110, 113-14, $117-121,124,128,138,140-42,144,155,170$, 177, 179, 181-82, 186-89, 191-93, 200, 206, 226, 254-55, 295, 299-307, 310

War on Terror, 96, 117

Weigel, Sigrid, 13, 294, 297

West, Mae, 146

Western, 4, 7, 9, 19, 23, 35, 38, 52, 80, 84, 90-91, 94, 97, 101, 110, 113, 118, 137-38,
140, 145, 154, 172, 177, 191-92, 196, 211, 218, $220,232-33,236-37,255,265,277,295$

Westerns, 5, 35, 101, 121, 190

Whitfield, Andy, 45, 51

Who's Afraid of Virginia Woolf?, 258

wives, $7,10,66-68,73,75^{-76}, 83,86-87$, $102,107,126,129,132,168,185,188-91$, 198, 200, 204, 214-15, 264, 286, 316-21

Winkler, Martin M., 5, 18, 21, 28, 37-39, 43, 45, 50, 53, 57, 61, 63, 96, 121, 153, 166, 173, $175,179,183-84,192-93,294,297$ women, $2-3,7,9,11,13-14,56,66-68$, 70-73, 75-77, 79, 84-89, 102, 111, 124-29, $131-33,137,142,144-46,157,168,170,176$, 180-82, 185-86, 188-91, 198, 202, 207, 213-16, 218-20, 223-25, 230, 249, 254-55, 257-69, 271-79, 282-99, 303-6, 309, $311-13,317-23$

womanizing, 8-9, 123, 125-26, 130, 135

World Vaishnava Association, 229, 238-43

World War II, 13-14, 34, 142, 295, 298-99, 305-6

worship, 9, 138, 143

writers, 18, 28, 72, 74, 100, 127, 143, 162, 213, 312

Wyler, William, 29

Xena: Warrior Princess, 3, 5, 10, 12, 34-35, 229-36, 239-41, 243-45, 256

Xerxes, 65, 68, 71, 74, 76-77, 84, 98-99, 106,121

Zeitlin, Froma, 214, 216, 227, 277, 297

Zeus, 2, 158-59, 162, 232, 275, 277, 279 